\title{
Cooling water management in European power stations Biology and control of fouling
}

Biologie et contrôle des salissures dans les circuits de refroidissement des centrales thermiques européennes

Henk A. Jenner, John W. Whitehouse, Colin J.L. Taylor and Michel Khalanski

\section{AUTHORS}

Henk A. Jenner, Ph.D., Biology, is a Senior Consultant at KEMA Power Generation in the Netherlands and is working in the fields of industrial cooling water use, biofouling research and ecotoxicology.

John $\mathrm{W}$. Whitehouse is a graduate in biology, geology and ecology; he joined the Central Electricity Generating Board's research department in the UK, and worked on ecological problems associated to cooling water discharges, cooling towers and water intake screens. Presently he is a private consultant.

Colin Taylor is a Senior Environmental Officer in British Energy PLC's Health, Safety and Environment Division. Working in applied aquatic ecology, he is also responsible for dealing with the environmental regulatory authorities. $\mathrm{He}$ is a graduate in marine biology and estuarine ecology.
Michel Khalanski is a Senior Research Engineer at Electricité de France, R\&D Division, Département Environnement. Working in applied aquatic ecology, he is presently in charge of the EDF biofouling research programme.

\section{CONTRIBUTORS}

Many colleagues have contributed to the writing of the book but in particular :

- Dr. J. Mattice of New-York Sea Grant (USA);

- Dr. J.H. I'Abeé-Lund of Norwegian Water Resources and Energy Adminstration (Norway);

- Dr. Rk Ambrogi of ENEL (Italy);

- Dr. R.N. Bamber of Fawley Aquatic Research Laboratory (UK); 
- Mr. J. Coughlan of Fawley Aquatic Research Laboratory (UK);

- Dr. L. Duvivier of LABORELEC (Belgium);

- Mr. T.H. Humphris (UK);

- Prof. J.-C. Moreteau and V. Bachmann of Université de Metz (France);

- Dr. S. Rajagopal of University of Nijmegen (The Netherlands);

- Dr. A.W.H. Turnpenny of Fawley Aquatic Research Laboratory (UK);

- Prof. Dr. G. van der Velde of University of Nijmegen (The Netherlands);

- our other colleagues from the various (power) companies who have helped us in this task, especially in completing the questionnaire which formed the basis of review of problems faced by power stations in Europe.

\section{ACKNOWLEDGEMENTS}

We wish to thank Electricite de France, British Energy PLC, Akzo Nobel and KEMA Nederland B.V. for the finance which enabled us to write this book. We also wish to thank EDF for undertaking the unenviable task of printing and publishing it.

We also wish to thank Bangor Univ. for the photographs of mussel and Cypris larvae and Elsevier and Dr. Elisabeth Gosling for their courtesy of using their figures. 


\section{Preface}

Electric power plants use huge amounts of water to complete the steam cycle and keep the electric turbines turning. Such volumes make it uneconomical to use treated water, so the sources are streams, lakes and the sea. But these waters contain bacteria and algae that can cause slime build-up on condenser tubes, and may as well contain the planktonic young of barnacles, mussels, etc. that attach and form mats on conduits and other plant structures. Uninhibited coIonization by either these micro- or macro-fouling organisms will cause reduced efficiency and, finally, shut down the plant. In the current global economy there is increasing pressure for higher efficiency and lower cost of electricity. Because fouling organisms are more difficult to control the longer they remain undisturbed after gaining a foothold, maintenance of both society's supply and the price of electricity depend, to a certain degree, on prevention or control of biofouling.

It is difficult to think about biofouling control at power plants without focusing on chlorine. Historically, chlorine application to the intake water stream has been the universal method of choice to combat biofouling. Intermittent application has always been the most common, because slime formation or microfouling was observed to be the primary problem. However, where macrofouling threatened power plant operation (mostly at marine sites), continuous application of chlorine at substantially lower concentrations was found to be effective. In addition, the cost of chlorine was small compared to the value of the electricity. The advantages of chlorine were overwhelming. However, in the early 1970's, organo-chlorine by-products were identified in power plant effluents during chlorination, and early toxicity tests suggested that these organo-chlorine by-products might be toxic at low parts per billion concentrations. Although it has not been possible to confirm the toxicity results, these potential environmental and public health implications sparked the first interest in a search for alternatives to chlorine for biofouling control.

During the middle 1970's, efforts were made to develop both physical and chemical alternatives that would avoid the byproducts of surface water chlorination. Physical methods for fouling control in the condenser tubes included the MAN brush system and the AMERTAP/TAPROGGE system's abrasive sponge balls. Both of these systems were found lacking for a number of reasons, the most important of them being increased erosion of the condenser and the need for supplemental chlorine application to control fouling of the service water system and other areas of the condenser cooling system. Other biocides, including ozone, bromine, bromine chloride, and hydrogen peroxide were also examined as poten- 
tial biofouling control agents, but the search for alternatives faded away around 1980. The fact that in sea water all of these oxidants yielded the same active ingredient - bromine probably played a role in abandoning the search, because similar unwanted, halogenated by-products could be expected. In addition, fresh water by-products of these alternatives appeared problematical. For example, it was predicted that the products of ozonation of natural waters could include ozonides, peroxides and epoxides. Although the likelihood of formation and identification of these products is uncertain, these classes of chemicals are of known environmental and public health concern. Whatever the reasons, the pressure to consider alternatives deminished, and the industry dependence on chlorine for biofouling control continued.

In the last few years, the response to the invasion of the US by the Zebra Mussel (Dreissena polymorpha) again focused attention on biofouling control alternatives. Further, over the past couple of decades, the water quality of lakes, rivers and estuaries in both Europe and the US has improved. This has raised expectations over the release of chemicals into natural ecosystems. One early example of this trend specifically related to biofouling was the State of Michigan's Chlorine Minimization Campaign: Utilities were required to reduce chlorine application until biofouling (microfouling) got out of control, then raise it to the minimum level required to establish control again. This resulted in a two- thirds reduction in the amount of chlorine used, and discharged, by utilities in the state. On a general basis, the International Joint Commission (Canada and the US) recently recommended that all chlorine manufacture and use be prohibited in the Great Lakes Basin. Regardless of the validity of this recommendation (at least one state in the region has argued strongly against it), this is further indication of the regulatory and resource agency trend toward reduction of discharges of chemical products and by-products into natural waters. The Zebra Mussel invasion is occurring during this trend towards reducing chemical discharges, and other regulatory agencies in the US are threatening utilities with the spectre of abolition of all chlorine and/or chemical biofouling control agents once the Zebra Mussel crisis has been met. It is clear that non-chemical alternatives will be viewed as having advantages over chemical control agents and it appears that non-chlorine alternatives will be considered better than chlorine. However, as voiced by one regulator who had been asked to compare chlorine control with that by a proprietary chemical for which (he said) insufficient fate and non-target effects data were available, 'Better the devil you know than the devil you don't know'. In other words, lack of knowledge is not a good reason to choose an alternative. Without solid comparable information it will be difficult, perhaps impossible, to choose amongst alternatives.

This book will compare the advantages and disadvantages amongst the 
biofouling control options or alternatives that are already in use in Europe. The objective is to provide a practical guidebook for selecting alternatives for use at a specific facility. Based on analogy with the Zebra Mussel, results will be useful, but may not be strictly predictive for North America. For example, Zebra Mussel growth and life cycle appear somewhat different in Europe and North America, suggesting that fine tuning of control strategies developed in Europe will be required on the other side of the Atlantic. This is not surprising given the complexity of biofouling and its dependence on the plant design and operational characteristics, and the organisms and conditions at the specific site. As indicated above, social and regulatory pressures can also influence choices. Conversely, the general principles developed over the long experience with the mussel in Europe were transferable and did save a lot of effort. In addition, the conclusions in the book will provide research direction for those who want to improve the tool chest of alternatives that can be used for biofouling control in the future.
The authors represent most of the groups involved in designing, operating and conducting research on power plant biofouling in Europe. They are privy to the sources of information, both in the grey and published literature. They have therefore been able to include information from studies that are difficult to locate and obtain because communication must usually occur not only across company, but national and language barriers as well.

The book is organized into five chapters plus references and annexes. Chapter 1 introduces the topics to be covered and reviews the problems. Chapter 2 presents synopses of pertinent life history information of the responsible fouling organisms. Methods that have proved useful to control or prevent biofouling in Europe are presented in Chapter 3. In Chapter 4 is dealing with the environmental impact of proven methods and the link with regulatory situation. Finally in Chapter 5 discussion and recommendations are presented, including future antifouling strategies.

Jack Mattice

New-York Sea Grant (USA) 


\section{CONTENT}

1. INTRODUCTION

2. THE ECOLOGY OF FOULING

2.1. The nature of biological fouling ................................................ 15

2.2. The marine fouling species and their operational ecology........... 20

2.3. Estuarine fouling ....................................................................... 32

2.4. Freshwater fouling .................................................................. 37

3. BIOFOULING CONTROL METHODS

3.1. An overview of the antifouling methods ...................................... 64

3.2. Water filtration ................................................................................. 72

3.3. Cleaning ............................................................................ 73

3.4. Water velocity .................................................................... 74

3.5. Heat treatment ........................................................................... 79

3.6. Paints and coatings ................................................................ 83

3.7. Chemical treatments with oxidizing compounds........................... 89

3.8. Chemical treatments with non-oxidizing compounds .................... 145

3.9. Other physical methods ............................................................. 155

3.10. Biological control .................................................................. 160

3.11. Biological monitoring ........................................................... 161

4. REGULATORY CONTEXT

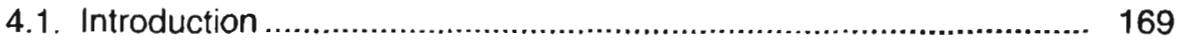

4.2. Basic principles of the European Union Legislation .................... 169

4.3. Existing EU Legislation .............................................................. 171

4.4. Forthcoming EU Legislation ....................................................... 175

4.5. Other International Commitments............................................... 177

5. CONCLUSION AND RECOMMENDATIONS .................................. 179

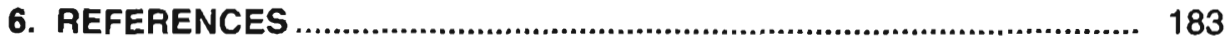

\section{ANNEXES}

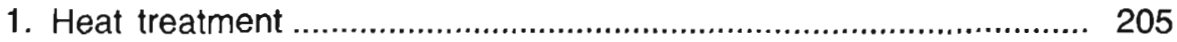

2. Legislation and policy in North america and selected EU member states 207

3. European power stations quoted in the text.................................. 221

ALPHABETICAL INDEX ON KEY WORDS ..................................... 223 


\section{Introduction}

\subsection{GENERAL}

In 1985 a collaborative working group of three major European power companies (CEGB-EDF-ENEL) plus the KEMA Research Institute in the Netherlands produced what became known as the 'Blue Book' (Whitehouse et al. 1985). This document summarised the methods used to control biofouling in power stations using saline water for cooling. It was also intended that the 'Blue Book' should be used by designers, to reduce the need for biocidal control. Problems requiring control throughout the operational life of the plant might be reduced in severity, if not eliminated, thereby reducing any impact of the discharge on the receiving waters.

Since 1985 many things have changed. Firstly, there has been the enacting of subsidiary national interpretations of the primary European environment legislation and international conventions. This development in the regulatory regime is continuing with the forthcoming EC Directive on Integrated Pollution Prevention and
Control, the Framework Directive on Water Policy and moves to introduce ecotoxicological appraisal of discharges. Secondly, there has been the privatisation and rationalisation of the electricity industry in the UK and Netherlands and the increasing possibility of this taking place elsewhere. Thirdly, there are a number of technical changes. New types of plant, using new materials, are coming into use; a number of new alternative biofouling control methods have been suggested or trialed; and the biogeographic distribution of species has evolved - partially naturally - but partially too because of anthropogenic influences. Improving water quality has led to greater diversity and new invasive species have been introduced via ship hulls and ballast water.

We are observing the unfortunate contraposition of increasing technical problems, the risk of loss of expertise, and an increasingly prescriptive regulatory regime. These various changes have led the successors of the original working group to believe that an update to the "blue book" is timely. 
In seeking to counter biological fouling, for all the reasons given above, we are currently in an extremely fluid situation.

As a consequence, the authors of this book do not consider it to be either exhaustive nor the final solution to these problems. Our objective is to describe the methods used to control micro- and macro-fouling in relation to the research and industrial applications undertaken in Europe over the past decades. In this book, we describe the methods used to combat the more usual forms of fouling known as micro- and macrofouling, based on many years of research and application of the methods in power stations in Europe. We also describe methods currently under investigation whose unproven efficacy and environmental impact do not, as yet, permit them to be included as standard methods.

\subsection{COOLING WATER CIRCUITS}

\subsubsection{Water intake systems}

The term 'intake system' is used here to mean those parts of the power station cooling water (CWS) system extending from the primary intake headworks at which water is withdrawn from the environment to the fine screens, of whatever kind employed (Fig. 1.1).

No matter the scale of the cooling water need, roughly the same collection of civil and mechanical systems are necessary to provide the cooling water to the station itself. A convenient distinction can be made between "offshore" intake systems and "onshore" intake systems.

Offshore intake systems can be used at marine and estuarine sites to minimize the water recirculation. Such a system typically comprises a bored tunnel or buried culvert which runs out from land, below the seabed, to open in relatively deep water some distance offshore. The openings of the intake are usually close to the seabed to avoid drawing in the warmer surface layers, and, in order to do this, may be equipped with some kind of concrete capping arrangement, sometimes known as a "velocity cap". Such an arrangement is believed also to reduce fish ingress, by eliminating vertical water currents which fish are ill-equipped to avoid (Schuler \& Larson 1974). Some form of coarse screening is always provided at the initial point of intake to prevent the entry of large items such as tree branches and fishing nets which might otherwise obstruct the $\mathrm{CW}$ tunnels.

Some offshore intakes have elaborate superstructures whilst others are entirely subsurface and their presence only evident from the necessary navigation marks. The former may provide access and support for cranes or other lifting gear designed for the insertion and removal of stop-logs and trash racks during maintenance. As such mechanical equipment is remote from normal power station operations and therefore difficult and costly to maintain in a hostile salt-water envi- 
(a) Offshore Intake

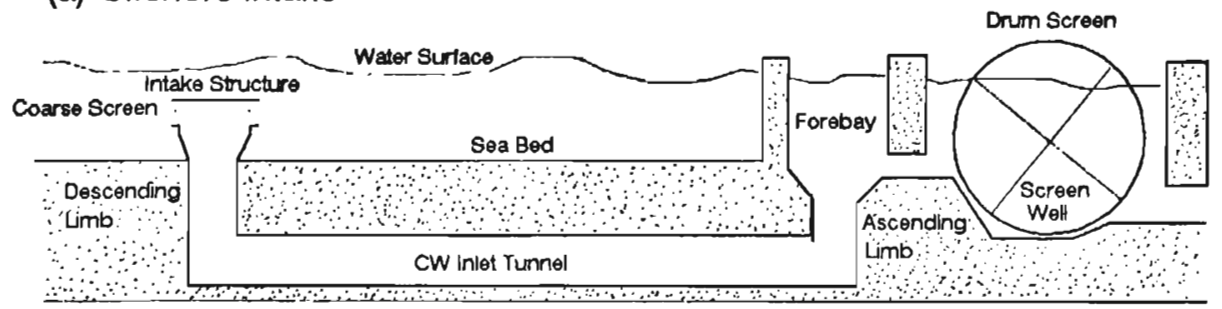

(b) Onshore Intake

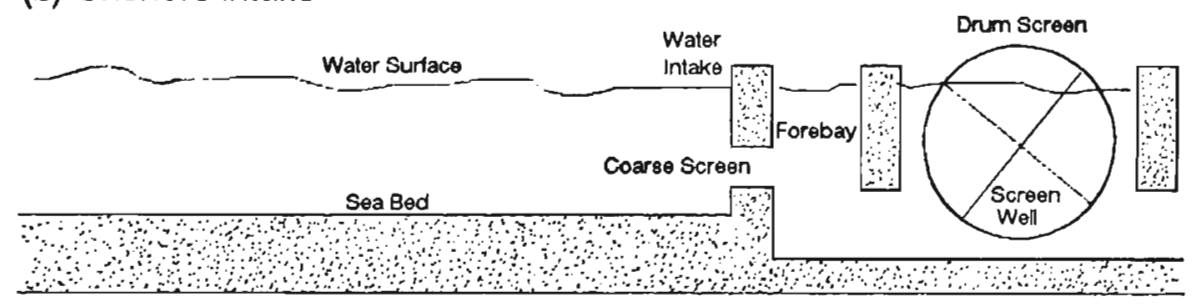

Fig. 1.1. - Comparison of the main features of offshore and onshore intake systems (sectional views).

ronment, it is commoner nowadays to dispense with such elaborations. The penalty of this evolution, however, is that it is now less practicable to dry down intake systems wholly to effect cleaning, forcing an increased reliance on pre-emptive antifouling controls.

The CW tunnel or culvert which conveys the water back to the main operational site is normally designed to do so with a velocity of $1.5-3.0 \mathrm{~m} / \mathrm{s}$, to prevent sedimentation. Typically, a descending shaft below the intakeheadworks on the seabed leads to the near-horizontal tunnel to prevent air retention. At the onshore end, the tunnel opens into a forebay or "intake surge shaft". This arrangement func- tions like a manometer: flow into the forebay chamber occurs by gravity as water is withdrawn from it by the $\mathrm{CW}$ pumps. The benefits are twofold: mechanical pressure stresses on civil structures, potentially caused by starting and stopping CW pumps are avoided, and an area is left accessable for potential isolation and maintenance.

Onshore intakes become practicable where deep water is found immediately close to shore. A dredged channel, often based on a pre-existing tidal creek or associated with a harbour, can provide this opportunity.

From the intake entrance, water passes to a forebay guarded by coarse screen and with provision in- 
serting stoplogs. From this point on, the $\mathrm{CW}$ system associated with both intake types become virtually identical: water drawn from the forebay passes through a series of parallel culverts. Across these culverts trash racks (vertical bar screens with $10 \mathrm{~cm}$ wide apertures) prevent drifting materials from being entrained further into the system. In some instances, for example where large quantities of loose seaweed occur, the trash rack can be equipped with automated rakes. These parallel culverts typically lead in turn to screen bays where fine materials are removed by moving screening systems. Here, two types of screening systems can be distinguished: band screens and drum screens.

Band screens are most common on older power stations, but are still used on new power stations having a CW flow of $5 \mathrm{~m}^{3} / \mathrm{s}$ or less. The screen comprises a continuously revolving belt of linked mesh panels (Fig. 1.2). Such a screen may be up to $4 \mathrm{~m}$ wide and the screens may descend into sumps up to $30 \mathrm{~m}$ deep, thus making them suitable for sites experiencing a large tidal range. Mesh sizes range from around $3.5 \mathrm{~mm}$ to $10 \mathrm{~mm}$, depending on location. The travelling screen is backwashed continuously by spray jets and all the impinged material is carried via sluices to a trash collecting system for subsequent disposal.

A fairly common screening system for sewerage and industrial use, including the dewatering of sewage sludge, the drum screen was introdu- ced to power stations in order to avoid the maintenance difficulties associated with the large number of moving parts of bandscreens. In the 1960's drum screens were widely introduced they saw widespread use, especially where there was a need to cope with high debris loadings.

As the name suggests, such a screen is in the form of a large rotating drum, which may be anything up to $25 \mathrm{~m}$ in diameter and ranging from 1 to $5 \mathrm{~m}$ in width. The required diameter is determined by the CW flow and the tidal range. The largest diameter drum screens are those for oncethrough cooling nuclear units which require more than $40 \mathrm{~m}^{3} / \mathrm{s}$ of cooling water, or at sites where tidal range is extreme. Mesh sizes are as for band screens, but the common usage in France is for $3.5 \mathrm{~mm}$ meshes, whereas in the UK $15 \mathrm{~mm}$ and in The Netherlands $10 \mathrm{~mm}$ is used (Fig. 1.3). The smallest screen mesh used in power stations is approximately $1 \mathrm{~mm}$.

\subsubsection{Cooling Systems}

Once water is obtained and screened via the intake system, it passes through the $\mathrm{CW}$ pumps and into the cooling system itself. One common component of all thermal power stations, whether nuclear or fossil fired, is a parallel series of heat exchangers of various sizes. These heat exchangers satisfy a diversity of needs, ranging from the very large condensers which cool the residual steam exhaled from the turbines, to auxiliary systems which cool ancillary plant such as die- 


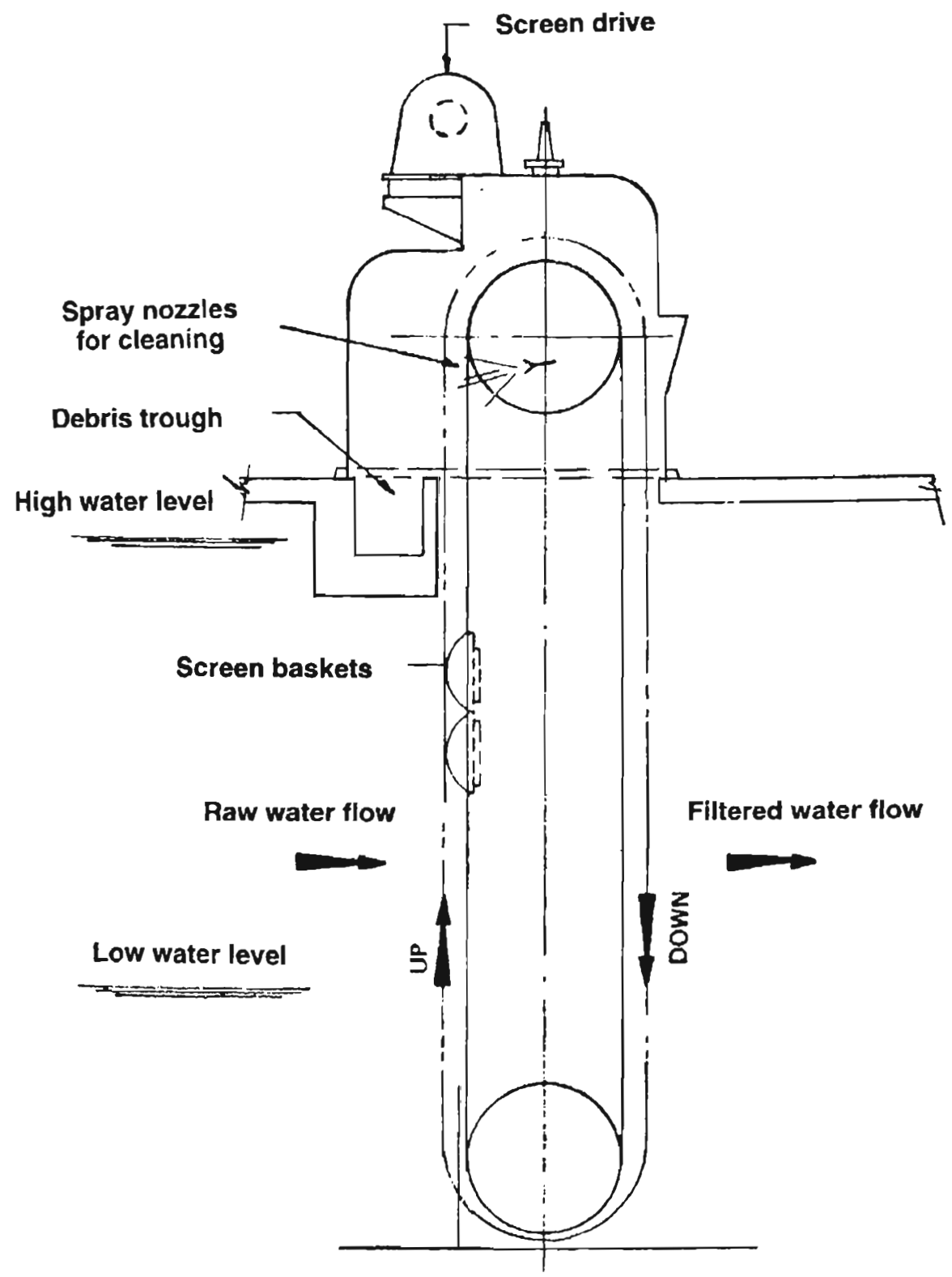

Fig. 1.2. - Conventional vertical travelling screen or "Band screen". 


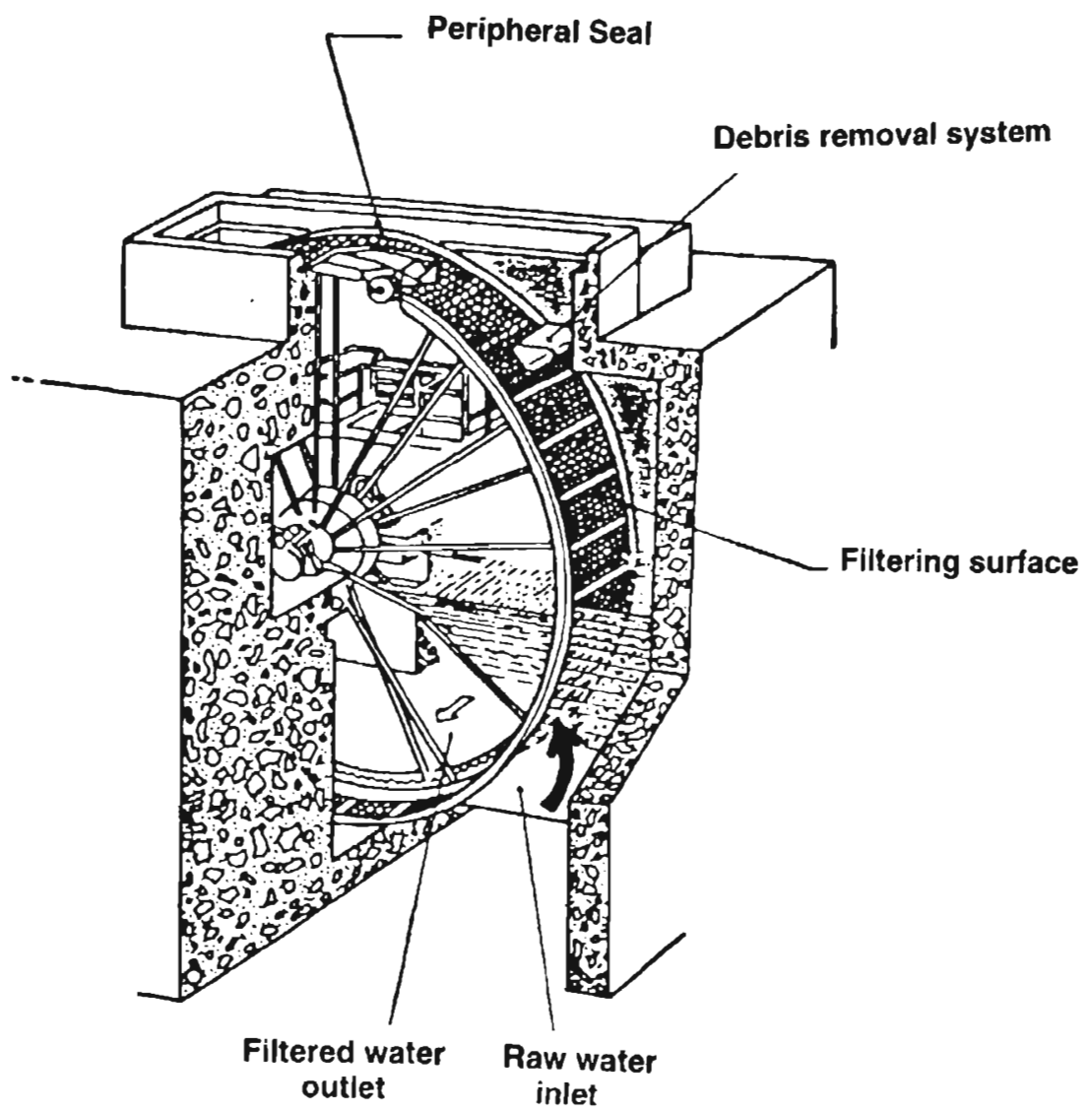

Fig. 1.3. - Drum screen arrangements.

sel generators, and standby plant which exists to provide additional cooling during outages or emergencies.

The bulk of the unwanted heat that such a power station has to deal with arises in the need to condense the residual steam exhaled from the turbines, in generating electricity. The steam is formed by heating water in a closed recirculating system as it passes through fossil fired boilers or analogous boilers or 'steam gener- ators' in nuclear plant. It is the physical process of condensing the steam back to water that drives the cycle. The efficiency of the steam cycle is a fundamental constraint upon the operational effectiveness of all thermal power plant and thus considerable effort at the design stage goes towards the optimisation of the $\mathrm{CW}$ plant itself. This is one good reason for the considerable diversity of detailed design between stations. 
Table 1.1. - Cooling water requirements and maximum temperature increase ( $\Delta$ Tmax) in French fossil fuel and nuclear power stations (Khalanski \& Gras, 1996).

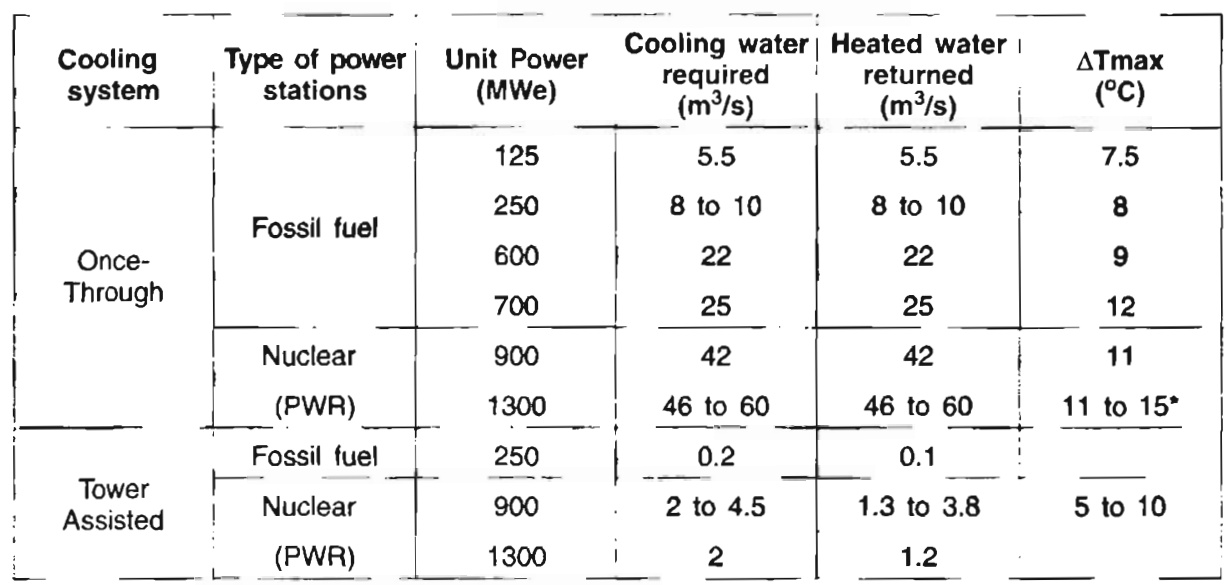

- $\Delta \operatorname{Tmax}=11^{\circ} \mathrm{C}$ on rivers, $15^{\circ} \mathrm{C}$ on the sea shore.

There are two types of heat exchanger: tube heat exchangers, where the coolant passes through the medium to be cooled via a bundle of narrow bore parallel tubes; and plate heat exchangers where the coolant and the medium to be cooled pass each other whilst divided by a parallel series of closely adjoined plates. Tube heat exchangers have the merit of being mechanically simple, but because they encourage laminar flow they are relatively inefficient heat transfer engines and thus tend to be large. In contrast, the plates in plate heat exchangers can be pressed to each other giving complex shapes, in turn giving a highly turbulent internal flow which increases the efficiency of the heat transfer process. Unfortunately this same factor increases both the likelihood and actual cost of fouling. in practice, large volumes tend to be dealt with by tube heat exchangers whilst ancillary plant often uses plate coolers.

There are two basic types of cooling system: direct and indirect.

In a direct system (sometimes called 'once-through') the water passes from the pumps through a parallel series of large and small heat exchangers before being passed straight back to sea or to river (Fig. 1.4). Unwanted heat is thus lost through dispersion of that effluent and its subsequent heat loss to the atmosphere. Very large quantities of fresh cooling water are necessary to satisfy such systems : typically $40-60 \mathrm{~m}^{3} / \mathrm{sec}$ per 1,300 MWe unit, with the coolant's temperature being raised by $11-15^{\circ} \mathrm{C}$ (Table 1.1).

The primary driver for using an indirect cooling system is a fundamental shortage of water supply. In an indirect system (sometimes called 're- 


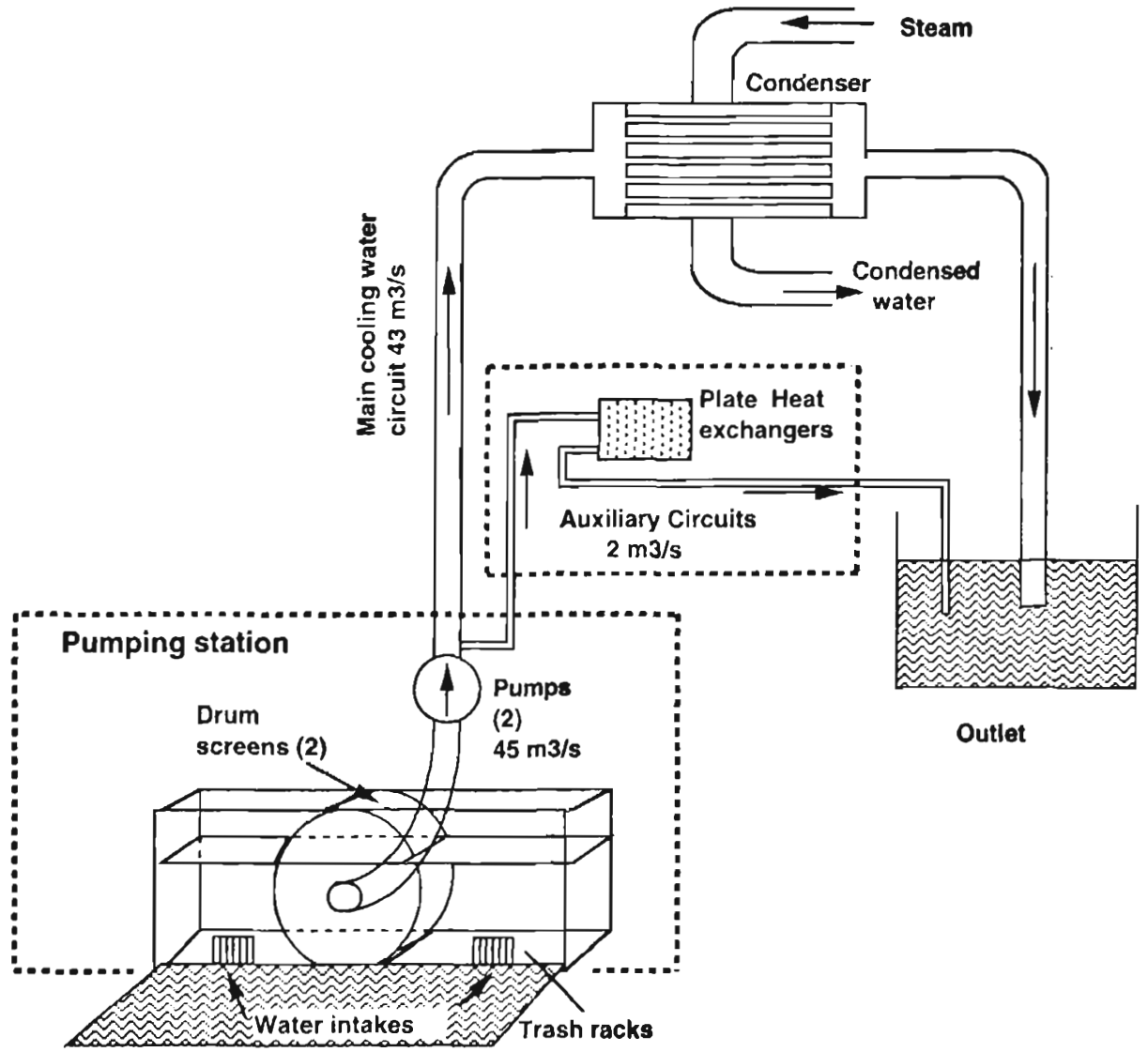

Fig. 1.4. - Schematic view of a direct cooling water circuit for a nuclear power station.

circulating') the cooling water passes to a recirculating circuit which then cycles it between the power station's heat exchangers and a means of transferring the waste heat acquired direct to the atmosphere. The water then passes back to the heat exchangers. The typical means of transferring this waste heat to atmosphere is to use 'cooling towers' - large civil structures that optimise convectional flows so as to maximise the efficiency of the heat transfer process. Cooling towers can be divided into two types: dry and wet.

In a wet cooling tower (see Fig. 1.5 and Lecœuvre et al., 1986) the warmed water is sprayed into the tower's void, descending against the incoming cooling air rising from its open base before being collected in a pond at the bottom. Such cooling towers normally have an internal cryptic structure (called 'packing') to maximise the surface 
Table 1.2. - Variation in size of cooling towers in relation to heat dispersal. EDF Stations.

\begin{tabular}{l|r|r|r|}
\multicolumn{1}{|c|}{ Station } & Power per unit (MWe) Base diameter $(\mathrm{m})$ & Height $(\mathrm{m})$ \\
\hline Fossil fuel & & & \\
Pont-sur-Sambre & 125 & 67 & 93 \\
unit 1 & 250 & 82 & 110 \\
units 2/3 & & & 163 \\
Nuclear Power stations & 900 & 144 & 178 \\
Dampierre-en-Burly & 1300 & 142 & 172 \\
Golfech & 1400 &
\end{tabular}

area of cooling water exposed to the air. Evaporative heat loss plays a significant part in the cooling process but also results in a loss of volume which has to be made up by the cooling water system ('make-up water'). A degree of continuous purging of the system ('blow-down'), which also has to be made up with fresh water, limits the concentration of dissolved salts by evaporation and avoids the precipitation of scale.

A variant to these 'natural draught' cooling towers is to employ fans to increase their efficiency. More recently designs have been introduced which use "counter current" or "crossflow" systems. In the former film fill design, the heated water is sprayed by nozzles above a PVC honeycomb-shaped packing. The cooling air passes up through the honeycomb channels, whilst the water forms a film which streams down the cell walls in the opposite direction before being collected. In the latter, PVC slats occur in a ring round the inside of the tower. Heated water is driven up to a warm basin above the ring and thence, through nozzles, is sprayed over the slats below. This splash fill arrangement allows water droplets to fall vertically through a horizontal air stream.

The increase in the scale of power plants in the decades to 1990 resulted in a tremendous increase in tower size (Table 1.2). For large nuclear units operated by EdF some $30,000 \mathrm{~m}^{3}$ of cooling water may typically be circulated, with a cooling water flow rate of $35 \mathrm{~m}^{3} / \mathrm{sec}$ and a $40,000 \mathrm{~m}^{3} / \mathrm{sec}$ air flow (Lecœuvre et al. 1986). Whether 'natural draught', 'forced draught', 'countercurrent' or 'crossflow', such 'wet' systems use only about $5 \%$ of the cooling water required by a direct cooled station of the same size (Table 1.1).

Where concerns may arise over the potential environmental and health impacts of an aerosol, the water supply is very poor, or a low power system is involved, 'dry' cooling towers have been introduced. In a 'dry' cooling tower the cooling water passes through sealed radiators, themselves cooled by the passage of air. 


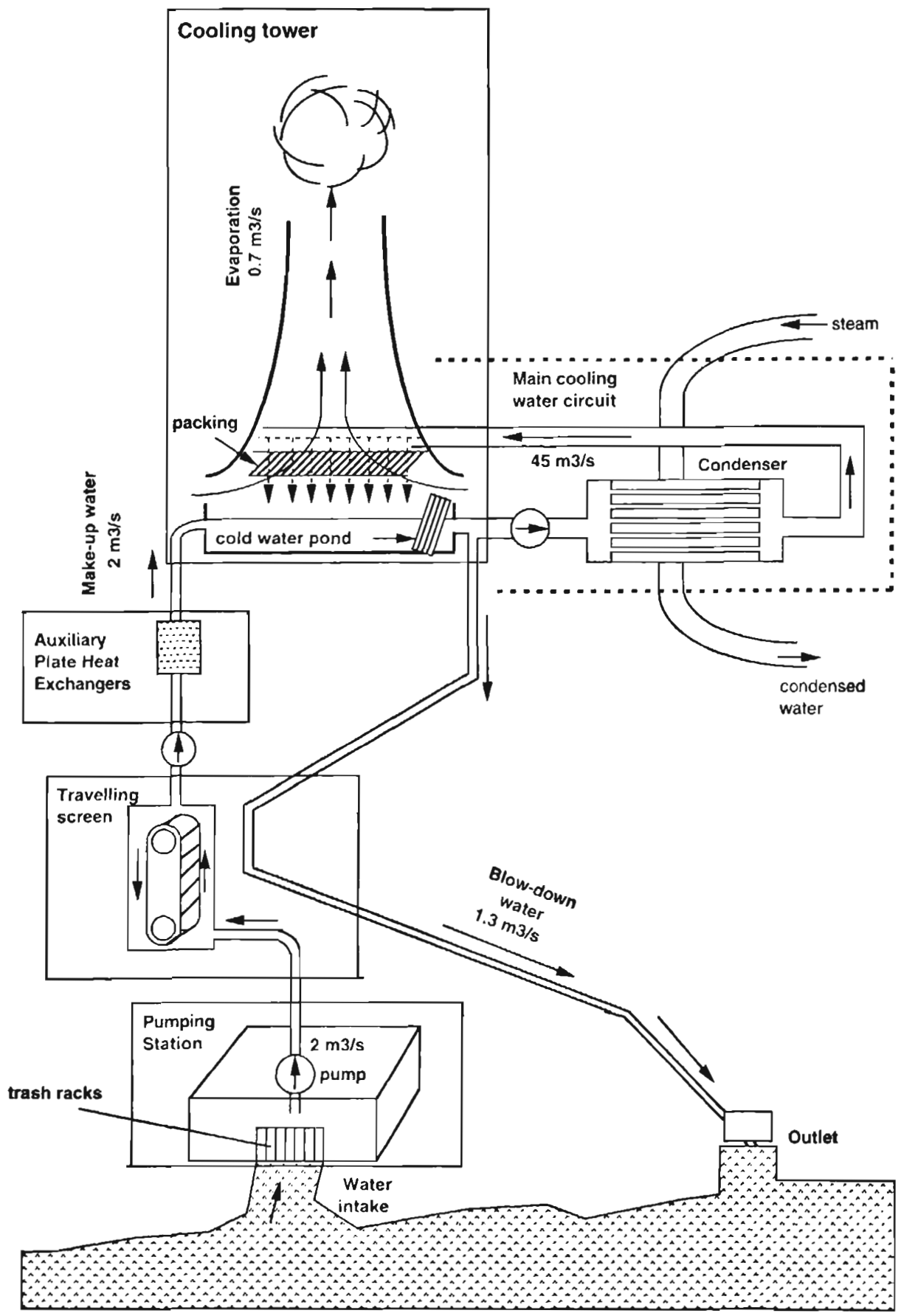

Fig. 1.5. - Schematic view of a closed cooling water circuit equipped with a natural draft wet cooling tower. 
This 'dry pack' can be associated with fans, and such structures are known as 'forced draft' cooling towers. Although such a system does not suffer (and in thermal efficiency terms, benefit) from significant evaporative loss, the chemical additives necessary to prevent corrosion and microbial fouling need to be purged to some degree, again requiring make-up from the cooling water intake system. Cooling systems employing this particular type of tower are subject to quite different fouling problems than those using 'wet' towers and fall outside the scope of this book. Some information can be found in the report of the Pisa Symposium (EPRI, 1988).

Some stations have hybrid cooling water systems, where a direct system is used in some circumstances and an indirect in others, or the two are used in combination. The common driver for employing such a hybrid is variable cooling water supply (such as when ambient water temperatures rise or actual river levels fall).

\subsection{Review of problems}

The main fouling problems encountered by power station operators across Europe are summarized in $\mathrm{Ta}$ ble 1.3 , as indicated by a variety of different companies and power stations through a questionnaire. It is obvious that various macroscopic organisms are responsible for problems in power station operation depending upon location and the source of the cooling water supply. Intractible and operationally difficult fouling is mainly caused by organisms with a shell of hard exoskeleton, such as mussels or barnacles. Special problems are found in cooling towers where bluegreen algae (Cyanobacteria) grow as thin sheets over the internal surfaces of the tower shell and the pack, causing blockage of the packing as well as the screens at the exits to the tower ponds.

Table 1.3. also shows that clogging at water intakes, caused by drifting plants, seaweeds, gelatinous organisms and entrained shoals of fish, is a major issue for the plant operators. Chemical fouling is also reported as a problem in circuits equipped with cooling towers.

As all internal surfaces of cooling systems can foul with biota, the complexity and variety of the systems in common use across Europe has resulted in a great diversity of foulingrelated operational problems. The next chapter deals with the species involved whilst chapter 3 deals with the means of preventing and containing the problems they provide. 
Table 1.3. - Survey of fouling and clogging organisms, and degree of fouling in marine, brackish and fresh water. In the last column, mitigation techniques and appropriate analytical methods are presented. (The degree of fouling is indicated as : + some; ++ fair ; +++ heavy).

\begin{tabular}{|c|c|c|c|c|}
\hline \multirow[t]{2}{*}{ Country } & \multicolumn{3}{|c|}{$\begin{array}{c}\text { Type of cooling water, associated fouling, } \\
\text { clogging and scaling }\end{array}$} & \multirow{2}{*}{$\begin{array}{c}\text { Main antifouling mitigation } \\
\text { techniques }\end{array}$} \\
\hline & Marine & Brackish & Freshwater & \\
\hline Belgium & & $\begin{array}{l}\text { Hydrozoat } \\
\text { Slime+t }\end{array}$ & $\begin{array}{l}\text { Slime++ } \\
\text { Zebra } \\
\text { mussels+ } \\
\text { Asiatic clams+ } \\
\text { Bryozoans++ } \\
\text { Gastropods++ } \\
\text { In cooling } \\
\text { towers : } \\
\text { scaling++ }\end{array}$ & $\begin{array}{l}\text { Freshwater: water filtration, } \\
\text { debris filters. On-line } \\
\text { condenser cleaning by } \\
\text { abrasive sponge balls. } \\
\text { Discontinuous Chlorination } \\
\text { with hypochlorite. }\end{array}$ \\
\hline Denmark & $\begin{array}{l}\text { Mussels+ } \\
\text { Slime+ }\end{array}$ & see marine & not used & $\begin{array}{l}\text { Marine water : water filtration, } \\
\text { debris filters. On-line } \\
\text { condenser cleaning by } \\
\text { abrasive sponge balls. Non- } \\
\text { toxic antifouling paints. }\end{array}$ \\
\hline France & $\begin{array}{l}\text { Mussels+++ } \\
\text { Barnacles++ } \\
\text { Clogging by : } \\
\text { seagooseberries } \\
\text { (jellyfish)+++ } \\
\text { seaweeds+++ }\end{array}$ & $\begin{array}{l}\text { Fouling: no } \\
\text { special } \\
\text { problems due } \\
\text { to wide } \\
\text { variations in } \\
\text { salinity in } \\
\text { large } \\
\text { estuaries. } \\
\text { Clogging by } \\
\text { driftings } \\
\text { macrophytes+ }\end{array}$ & $\begin{array}{l}\text { Zebra } \\
\text { mussels++ } \\
\text { Bryozoans++ } \\
\text { Algae++ } \\
\text { Gastropods++ } \\
\text { Asiatic clams+ } \\
\text { In cooling } \\
\text { towers: } \\
\text { scaling++ }\end{array}$ & $\begin{array}{l}\text { Marine water: water filtration, } \\
\text { debris filters. On-line } \\
\text { condenser cleaning by } \\
\text { abrasive sponge balls (some } \\
\text { units). Continuous chlorination } \\
\text { at low dosing (0.5-1.0 mg/L), } \\
\text { with electrochlorination } \\
\text { Freshwater: water filtration, } \\
\text { debris filters. On-line } \\
\text { condenser cleaning by } \\
\text { abrasive sponge balls. Shock } \\
\text { chlorination once or twice a } \\
\text { year. }\end{array}$ \\
\hline Germany & & & $\begin{array}{l}\text { Zebra } \\
\text { musselst } \\
\text { Slime+t } \\
\text { In cooling } \\
\text { towers: } \\
\text { scaling++ }\end{array}$ & $\begin{array}{l}\text { Freshwater : water filtration, } \\
\text { debris filters. On-line } \\
\text { condenser cleaning by } \\
\text { abrasive sponge balls. } \\
\text { Discontinuous chlorination } \\
\text { with hypochlorite. } \mathrm{H}_{2} \mathrm{O}_{2} \text {. }\end{array}$ \\
\hline Ireland & $\begin{array}{l}\text { Mussels+ } \\
\text { Slime+ } \\
\text { Clogging by : } \\
\text { fish+++ }\end{array}$ & see marine & Zebra mussels & $\begin{array}{l}\text { Marine water : water filtration, } \\
\text { debris filters. On-line } \\
\text { condenser cleaning by } \\
\text { abrasive sponge balls. } \\
\text { Continuous chlorination with } \\
\text { hypochlorite. }\end{array}$ \\
\hline
\end{tabular}


Table 1.3. - (suite)

\begin{tabular}{|c|c|c|c|c|}
\hline \multirow[t]{2}{*}{ Country } & \multicolumn{3}{|c|}{$\begin{array}{c}\text { Type of cooling water, associated fouling, } \\
\text { clogging and scaling }\end{array}$} & \multirow{2}{*}{$\begin{array}{l}\text { Main antifouling mitigation } \\
\text { techniques }\end{array}$} \\
\hline & Marine & Brackish & Freshwater & \\
\hline Italy & $\begin{array}{l}\text { Mussels+++ } \\
\text { Hydroids++ } \\
\text { Tubeworms++ } \\
\text { Barnacles++ } \\
\text { Slime++ } \\
\text { Clogging by : } \\
\text { seaweeds+ } \\
\text { Posidonia+ }\end{array}$ & $\begin{array}{l}\text { (only one } \\
\text { station) } \\
\text { Clogging by: } \\
\text { seaweeds+ } \\
\text { debris+ }\end{array}$ & $\begin{array}{l}\text { Slime++ } \\
\text { Clogging by : } \\
\text { drifting } \\
\text { plants, } \\
\text { leaves+ } \\
\text { Zebra mussels }\end{array}$ & $\begin{array}{l}\text { Marine water : water filtration, } \\
\text { debris filters. On-line } \\
\text { condenser clearing by } \\
\text { abrasive sponge balls. } \\
\text { Continuous or intermittent } \\
\text { chlorination by hypochlorite or } \\
\text { electrochlorination. } \\
\text { Freshwater: water filtration, } \\
\text { debris filters. On-line } \\
\text { condenser cleaning by } \\
\text { abrasive sponge balls. } \\
\text { Intermittent chlorination (very } \\
\text { few cases). }\end{array}$ \\
\hline $\begin{array}{l}\text { The } \\
\text { Netherlands! }\end{array}$ & $\begin{array}{l}\text { Mussels+++ } \\
\text { Slime++ } \\
\text { Clogging by : } \\
\text { jellyfish+++ } \\
\text { fish++ }\end{array}$ & $\begin{array}{l}\text { Mussels+t } \\
\text { Slime+ } \\
\text { Clogging by: } \\
\text { fish+ }\end{array}$ & $\begin{array}{l}\text { Zebra } \\
\text { mussels+ } \\
\text { Slime++ } \\
\text { Clogging by: } \\
\text { fish++ }\end{array}$ & $\begin{array}{l}\text { Marine \& Freshwaters : } \\
\text { water filtration, debris filters. } \\
\text { On-line condenser cleaning by } \\
\text { abrasive sponge balls. Heat } \\
\text { treatment. Chlorination with } \\
\text { hypochlorite: continuous or } \\
\text { discontinuous, pulse } \\
\text { chlorination. }\end{array}$ \\
\hline Norway & & r. & $\begin{array}{l}\text { Hydro-power: } \\
\text { only } \\
\text { problems with } \\
\text { migrating fish. }\end{array}$ & \\
\hline Portugal & $\begin{array}{l}\text { Mussels++ } \\
\text { Slime+ }\end{array}$ & : & Asiatic clams+ & $\begin{array}{l}\text { Marine water: water filtration, } \\
\text { debris filters. On-line } \\
\text { condenser cleaning by } \\
\text { abrasive sponge balls (some } \\
\text { units). Continuous chlorination } \\
\text { at low dosing }(0.5-1.0 \mathrm{mg} / \mathrm{L}), \\
\text { with electrochlorination } \\
\text { Freshwater : water filtration, } \\
\text { debris filters. On-line } \\
\text { condenser cleaning by } \\
\text { abrasive sponge balls. }\end{array}$ \\
\hline Spain & $\begin{array}{l}\text { Slime+ } \\
\text { Tubeworms+ } \\
\text { Mussels++ } \\
\text { Oysters+ }\end{array}$ & $\vdots$ & $\begin{array}{l}\text { Slime++ } \\
\text { In cooling } \\
\text { towers: } \\
\text { scaling++ }\end{array}$ & $\begin{array}{l}\text { Marine \& Freshwater : water } \\
\text { filtration, debris filters. On-line } \\
\text { condenser cleaning by } \\
\text { abrasive sponge balls. } \\
\text { Discontinuous chlorination, } \\
\text { low and shock dosing, with } \\
\text { hypochlorite and } \\
\text { electrochlorination. }\end{array}$ \\
\hline $\begin{array}{l}\text { United } \\
\text { Kingdom }\end{array}$ & $\begin{array}{l}\text { Barnacles+ } \\
\text { Mussels++ } \\
\text { Slime++ } \\
\text { Clogging by : } \\
\text { fish+++ } \\
\text { seaweeds++ } \\
\text { jellytish+ }\end{array}$ & see marine & $\begin{array}{l}\text { Slime++ } \\
\text { In cooling } \\
\text { towers: } \\
\text { scaling++ }\end{array}$ & $\begin{array}{l}\text { Marine \& Freshwaters : } \\
\text { water filtration, debris filters. } \\
\text { On-line condenser cleaning by } \\
\text { sponge balls. Continuous } \\
\text { chlorination (intermittent in } \\
\text { winter) with hypochlorite and } \\
\text { electrochlorination. }\end{array}$ \\
\hline
\end{tabular}




\section{The ecology of fouling}

\subsection{THE NATURE OF BIOLOGICAL FOULING}

\subsubsection{Introduction}

Any surface exposed to natural fresh or saline waters provides an opportunity for the settlement and subsequent growth of organisms, as a very great diversity of aquatic species whose adults live attached to solid surfaces employ planktonic larvae for dispersal. The internal surfaces of the various engineering systems described in the previous chapter can provide an ideal habitat for such species. As the majority of these species are sessile and live by filtering suspended matter out of the overlying water, the internal CW systems are virtually ideal : the steady flow conditions guarantee a continuous supply of food and dissolved oxygen, and the velocity sheer and physical screening mean that predators are few. Given such perfect conditions, settlement occurs readily and growth can be rapid. Without constraint this growth can begin to interfere with the operational systems, and will lead to their failure. The phenomenon is known as biological fouling, or 'biofouling', and is an entirely natural process. From the perspective of a power station operator the development of such fouling within the CW system is entirely undesirable and needs to be kept in check.

The fouling of power station CW plant is recognised as taking five different forms: 'trash', biological 'microfouling', biological 'macrofouling', siltation, and scaling.

\subsubsection{Trash}

'Trash' is the commonly used term (derived from American parlance) for the unwanted material swept into a power station which, unless intersected by screens, would lead to the immediate physical blockage of internal plant such as the condensers and heat exchangers. This material typically consists of inert debris such as plastic bags and bottles, driftwood, steel drums, drifting seaweed, hy- 


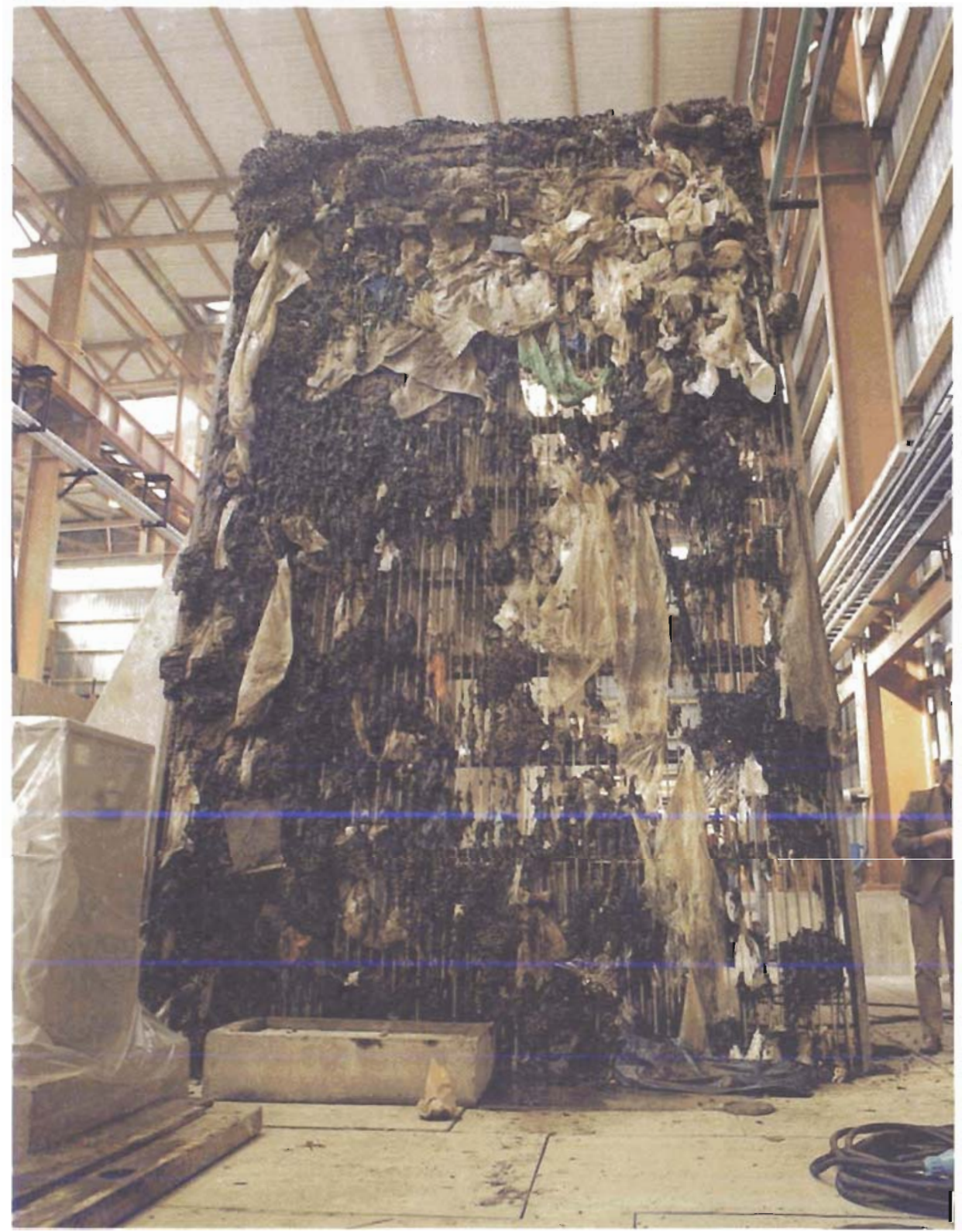

Photo 2.1. - Trash rack, lifted out of the intake, showing severe fouling with plastics (Gravelines Nuclear Power Station). 
droids, reeds and leaves, and sometimes sewage solids. It also includes the larger organisms, naturally occurring in the water column, casually entrained by the cooling water flow: jellyfish (including the sea gooseberry Pleurobrachia pileus) and fish. Given that this 'trash' can thus include very significant quantities of fish, otherwise of intrinsic or potential commercial value, the use of the word itself and its inference that the material is simply waste to be disposed of is singularly unfortunate.

The trash racks frequently placed downstream of the intake forebay (Photo 2.1) provide the first line of defence against this material, with the rotating screens removing much of the rest. Any material which passes through the screens and penetrates the main and secondary cooling systems is called 'debris'. This can include fragments of fishing nets, reed fibres, and hydroid or barnacle fragments. Such debris causes problems with screens and endplates in small sized heat exchangers.

The fish species entrained and subsequently impinged upon the screens can include those migrating along rivers or through estuaries, such as eels, lampreys, salmonids and shads (Alosa spp.). They can also include species such as sprat (Sprattus sprattus) and herring (Clupea harengus), which may occur in dense shoals. If such a shoal is entrained the volume of fish can begin to overload the capacity of the rotating screens, impeding the flow of cooling water to the condensers and endan- gering sustained electricity generation. Similar impacts can occur with jellyfish, leaves and drifting seaweed.

As ameliorating fouling problems caused by 'trash' and 'debris' requires separate solutions to those employed in controlling the biofouling of surfaces, this topic will be the subject of a subsequent publication.

\subsubsection{Microfouling}

When a surface is first placed in seawater or riverwater it is immediately coated with a film consisting of proteins, polypeptides, polysaccharides and lipids produced by aquatic organisms or derived from their degradation products. Bacteria common to these waters settle on the film, especially those which have a pellicle and produce slime as a part of their metabolic functioning (Characklis, 1981), and within six hours will have consolidated their presence, as polymeric fibrils are exuded from them within the film.

The establishment of a microbial film can have a significant effect on heat exchange performance in the main condensers and auxiliary coolers, made worse by the fact that such fouling of untreated warm condenser tube surfaces will occur all year round. Within seven days at temperatures of 10 to $20^{\circ} \mathrm{C}$, a layer of bacteria some 50-100 $\mu \mathrm{m}$ or more thick will have developed on a freshly exposed surface. Waste products from these microorganisms contribute to the film itself. After fourteen days such a slime film 
will reach its maximum thickness, which rarely exceeds a few hundred $\mu \mathrm{m}$ even in nutrient-rich waters. The biofilm so formed can act as an anchor for any silt or mud in the water and such deposits further impair heat transfer.

The speed of biofilm formation depends to a large extent upon the metals involved: titanium condenser tubes are very rapidly colonised, whereas the surface dissolution of cupronickel and brass condenser tubes has a toxic influence on bacteria, retarding settlement and growth.

Once a biofilm has become established, a succession then occurs where the original colonisers are progressively replaced, or supplemented, by others. This is a complex process made all the more so by the highly variable geographic distribution of species and the fact that some organisms are only present in the water column at certain times of year, with their relative abundance sometimes varying considerably from one year to another. The final 'climax' assemblage of species on a surface will thus depend upon geographic variables and the environmental conditions offered, such as substrate type, the presence or absence of light, flow conditions, salinity, and water quality. Some of the organisms that may settle are not microbial, but the larvae of macroscopic species. If these larvae survive to grow on towards maturity this will lead to macrofouling of the systems involved.

It is frequently quoted in the literature that a microbial film is a necessary precursor for macrofouling and that the maintenance of a robust microfouling control tends to go a long way to controlling macrofouling too. Observations made with artificial collectors of larvae made up of PVC plates or glass slides, show that when larvae are ready to settle, they do not necessary wait for the development of the microbiological layer. Larvae of zebra mussels, marine blue mussel and barnacles are capable of settling rapidly on surfaces free of a microbial film. This strongly implies that elimination of microfouling by a given treatment cannot be the only criteria of success in preventing macrofouling, as the toxic process responsible for bacterial control may have no effect on the macrofouling itself.

\subsubsection{Macrofouling}

Macrofouling organisms readily colonise man-made surfaces, including those of power station cooling water intake tunnels and culverts, the screen forebays and rotary screen wells, condenser tube plates and heat exchangers. One of the most troublesome of these organisms in coastal waters is the common blue or edible mussel, Mytilus edulis, and it is the problems caused by this species that first led to the development of fouling control strategies at power stations. Although blue mussels are a notorious example of a fouling species, there are many others. In non-tidal low salinity waters such as the Noordzeekanaal in the Netherlands the brackish water mussel, Mytilopsis leu- 
cophaeata, is found; in freshwater the equivalent is the Zebra mussel, Dreissena polymorpha. Another bivalve mollusc, the Asiatic Clams Corbicula fluminea and Corbicula fluminalis are is known for causing severe problems in North America but in recent years has been found in the Rhine, the Moselle (Bachmann et al., 1995) the Rhone, (Khalanski, 1997a, b), and the Garonne basin (Dubois, 1995).

Each macrofouling species has its own characteristics in terms of settlement behaviour, and the effects and the occurrence of each species varies with site, season, and between years. The biology and ecology of the most significant species are described in Section 2.2 below.

\subsubsection{Siltation}

On a direct cooled power station silt can be deposited from suspension in the entrained water anywhere the water velocities drop below a critical value. Generally speaking, power station cooling water systems are designed to maintain laminar and constant flow within the pipeworks and culverts, and turbulent flow at intersections such as forebays and surge shafts. This design approach prevents the significant accumulation of silt, as the suspended material is simply flushed through. Slack areas do occur in wide forebay systems, but these are generally designed in such a way that any silt accumulations can readily be removed by occasional limited dredging.
When siltation is found to be occurring within cooling water culverts and auxiliary cooling systems it will very often stem from biological fouling, even though the evidence of that biological activity may have become obscured with the passage of time. There are two mechanisms for this. Firstly, when macrofaunal organisms settle onto surfaces and grow, the depth of the low flow boundary layer lying over the settled surface is increased. This increases the slack volume within a culvert or pipework and increases the liklehood that silt will settle. Secondly, both microfouling organisms and macrofouling organisms add waste organic matter to their surroundings. Silt can readily be incorporated into a biofilm, but it is the particular feeding habits of mussels that can provide the worst problems. As will be described in more detail later, mussels filter out suspended material from the passing water very efficiently. In conveying this material across their feeding gills, sorting favoured material, a mucus film is added. The unwanted material, bound by this mucus, is ejected as 'pseudofaeces'. A considerable volume of suspended material can be processed in this way, and the resultant pseudofaeces are more likeley to adhere and settle to surfaces. This can result in very considerable drifts of accumulation within the cooling water systems, and can lead to great amounts of deposits in heat exchangers, especially plate heat exchangers. As a result, a problem that has a biological origin can readily be mistaken for a purely physical process, 
and this can lead to an inadequate response being taken by the operator.

Within an indirect cooled power station, silt can be deposited if the make-up water has a high suspended solids load. This can lead to difficulties if the silt is deposited in low flow zones, especially cooling tower ponds. Silt may enhance the impact of biofilms by becoming entrained within them, greatly increasing the deposits in condenser tubes and on cooling tower packing. It is not unknown for silt to accumulate so quickly that the cooling tower ponds become filled to the brim, greatly reducing the carrying capacity of the closed circuit. Similar problems have overcome newly installed plastic packing systems.

\subsubsection{Scale}

This is a problem largely specific to power stations using cooling towers. Scale is the precipitation of dissolved salts, mainly calcium carbonate, which then form a layer on the cooling water side of heat exchangers, with a not dissimilar effect upon heat transfer efficiency to that caused by a biofilm. Scale deposit on plastic packing, especially on "honeycomb" film fill, can severely increase the fill weight, threaten the stability of the fill structure and reduce the thermal exchange capacity of the cooling tower. The quantity and quality of the makeup water entering the system, the flow rates of the circulating water, the inlet and outlet temperatures of the condensers, and the nature of any che- mical additives, all influence the rate of scale formation.

As with trash, and siltation except in so far as it occurs as a consequence of biological fouling, the amelioration of potential scaling problems falls outwith the context of this publication.

\subsection{THE MARINE FOULING SPECIES AND THEIR OPERATIONAL ECOLOGY}

For the sake of consistency, the various species are described here in the context of their known ability to foul direct cooled systems, as described in Section 1.2. In practice, all power stations which use saline water for cooling are directly cooled. Further, on such stations the bulk of any fouling is found on the intake side of the cooling system. On the discharge side of cooling systems the water temperature is generally high enough during the summer months to eliminate most of the marine fouling species.

\subsubsection{Mussels}

\section{Taxonomy and distribution}

The best known of all the macrofouling organisms and the one causing the most widespread and serious problems for coastal and estuarine power stations, is the Common or Blue Mussel, Mytilus edulis (Photo 
2.2). Mussels of the genus Mytilus are bivalves belonging to the family Mytilidae, which are members of the Order Anisomyaria, bivalves with unequal muscles for shell closure.

$M$. edulis has a wide distribution in both the northern and southern hemispheres. Around Europe there are other closely related species which have a more restricted geographical distribution :

- Horse mussel (Modiolus modiolus) Bay of Biscay to North British Isles;

- Bearded horse mussel (Modiolus barbatus) Mediterranean, Biscay, English Channel and North Sea;

- Mediterranean mussel (Mytilus galloprovincialis) Mediterranean, AtIantic Coast, Biscay up to the English Channel and round the Irish coast.

All of these may colonise cooling water systems. A clear understanding of the distribution of the various Mytilus species and the implications of this for fouling control are unlikely to be forthcoming soon. M. galloprovincialis was only recently confirmed as a separate species from $M$. edulis over the northern part of its range. The two are difficult to tell apart, and frequently coexist in the same region.

Previously, (Whitehouse et al. 1985) it was suggested that $M$. edulis was the more widespread species, with a restricted distribution of $M$. galloprovincialis. It was also understood that more sites in France have M. ga/loprovincialis than those in Great Bri. tain. This view has had to be revised in the light of recent genetic and mor-

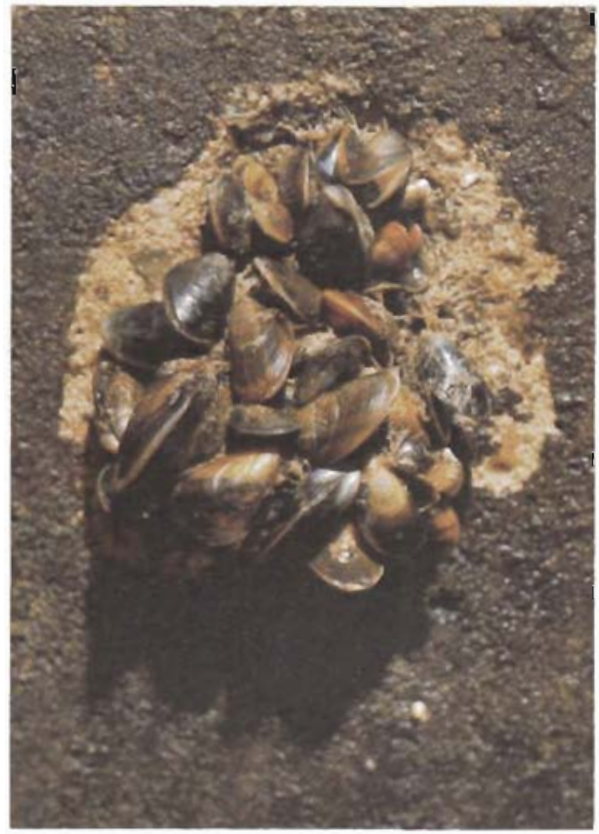

Photo 2.2. - The common mussel Mytilus edulis, showing the characteristic clump formation normally found in cooling water intakes. Note also the byssus threads which anchor the mussel to the substrate.

phological analysis (see Gosling (ed.) 1992). It would now appear that there are six species, of which only three are relevant to the problems of power station macrofouling in European Waters: M. edulis, M. galloprovincialis and M. trossulus (Fig. 2.1).

What is known of the distribution of $M$. galloprovincialis in the British Isles and Northern France shows it is no longer a simple matter of identifying all mussels from northern power stations as $M$. edulis. This has never been a question for specimens from Mediterranean power stations, which were clearly M. galloprovincialis. Thus, 


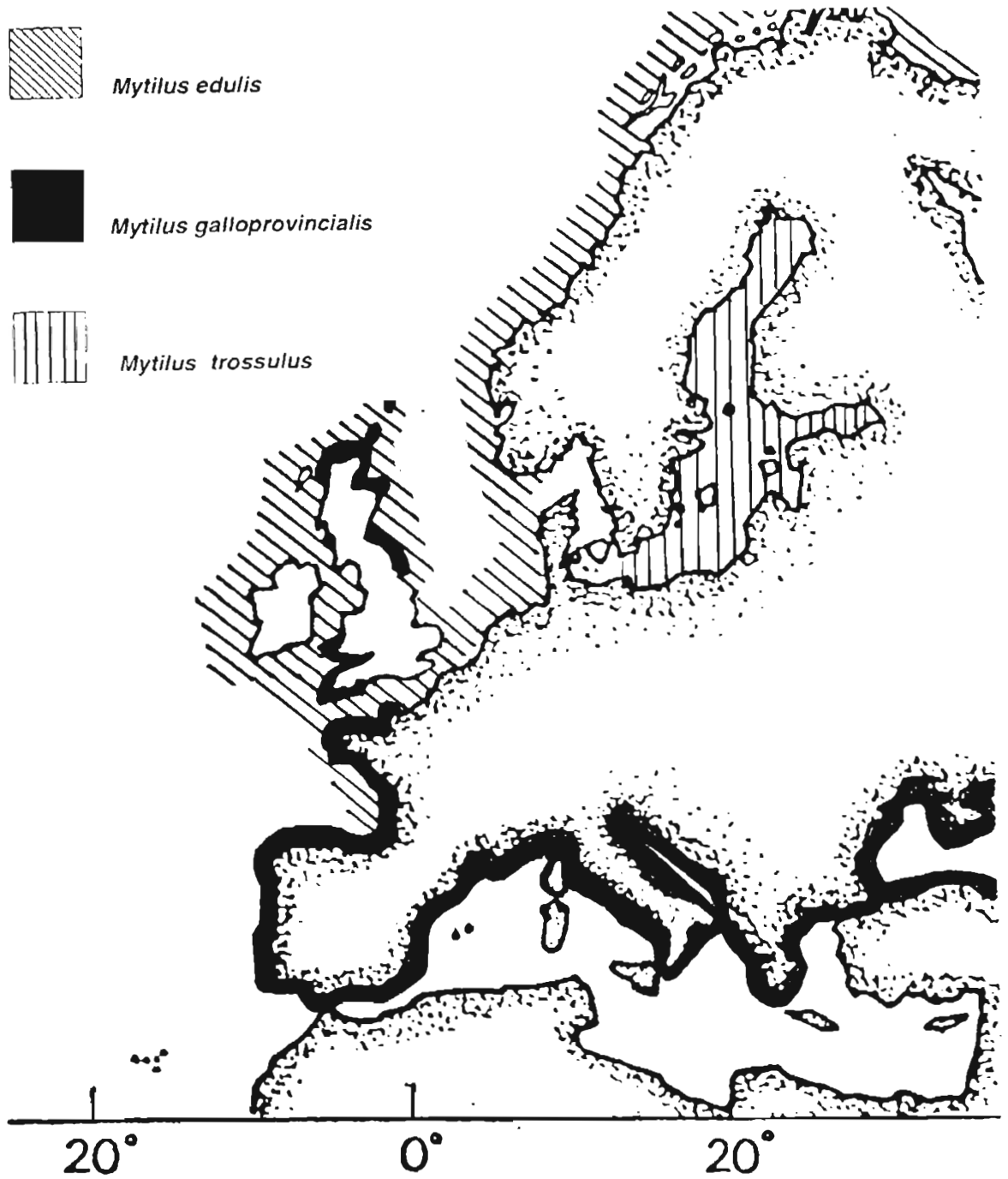

Fig. 2.1. - European distribution of the three species of Mytilus detected using morphological and electrophoretic markers (Alter Gosling. (ed.) 1992).

a problem has developed as there are clear zones of hybridisation between $M$. edulis and $M$. galloprovincialis. The physiology of these hybrids may differ from data determined on specimens assumed to be uniformly $M$. edulis or M. galloprovincialis, and thus may differ in their relative success as fouling organisms and the relative success of the means of combatting them. 


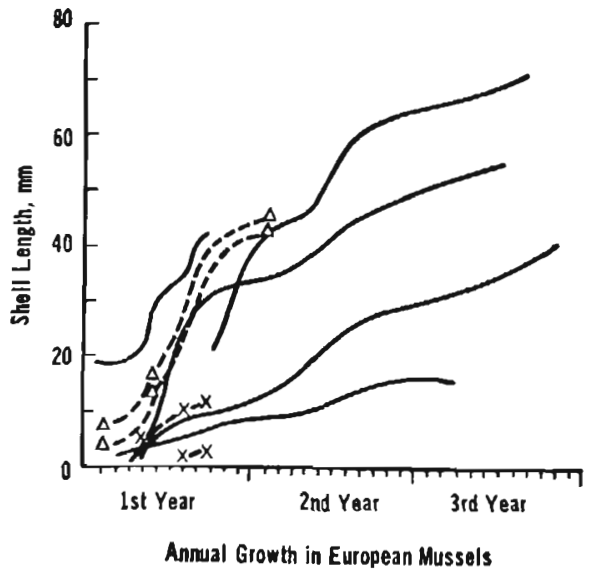

Fig. 2.2. - Growth curves of $M$. edulis in the North Sea and English Channel. Whitehouse et al. (1985b).

\section{Biology and reproduction}

The two shell valves of Mytilus spp. vary in colour from black to brown. The shells are often overgrown with barnacles, hydroids and other encrusting organisms. Mytilus is found throughout the intertidal zone and in the near subtidal region. Growth of the shell occurs through deposition of calcareous material by the mantle to the free edge of the shells. The mantle is the thin layer of tissue which lines the inside of the shells.

Food is acquired by filtering particles and by the use of dissolved organic matter from the sea water. So to a large extent the rate of growth is dependent on the nutritional status of the water and on water temperature. This accounts for large differences in growth between some sites from the English Channel, and the North Sea, for example, between Dungeness and Dunkerque (Fig. 2.2).
There is a wide range of salinity limits to the distribution or the survival of Mytilus spp. except their ability to cope with marked fluctuations between saline and fresh water conditions over twenty four hour periods as found in estuaries. Such mussels are usually stunted specimens which are very slow growing (see Seed \& Suchanek, 1992).

Reproduction is highly temperature dependent, with the production of eggs (oogenesis) and sperm (spermatogenesis) taking place in specialised pockets over the whole of the mantle. Experimental studies have shown that gametogenesis is accelerated by water temperatures between $4{ }^{\circ} \mathrm{C}$ and $11^{\circ} \mathrm{C}$ but slows down at about $11^{\circ} \mathrm{C}$. At $17^{\circ} \mathrm{C}$, gametogenesis and egg laying are partially inhibited and some cytolysis of oocytes is to be seen. Following sexual development in the winter, reproduction continues through spring and summer (Lubet, 1983). Prior to release of the eggs and sperm, the mantle is swollen by reproductive tissue. Fertilisation takes place in the sea when water temperatures have reached about $10^{\circ} \mathrm{C}$, that is after mid-March up to the end of September, with the main period in April to June. After fertilisation, the eggs develop into free- swimming larvae called veligers (Photo 2.3). Depending on water temperature and food, the larvae develop within 24 weeks into the final larval stage, the pediveliger. During reduced food conditions and/or low water temperatures, the planktonic stage can be prolonged by several weeks. 


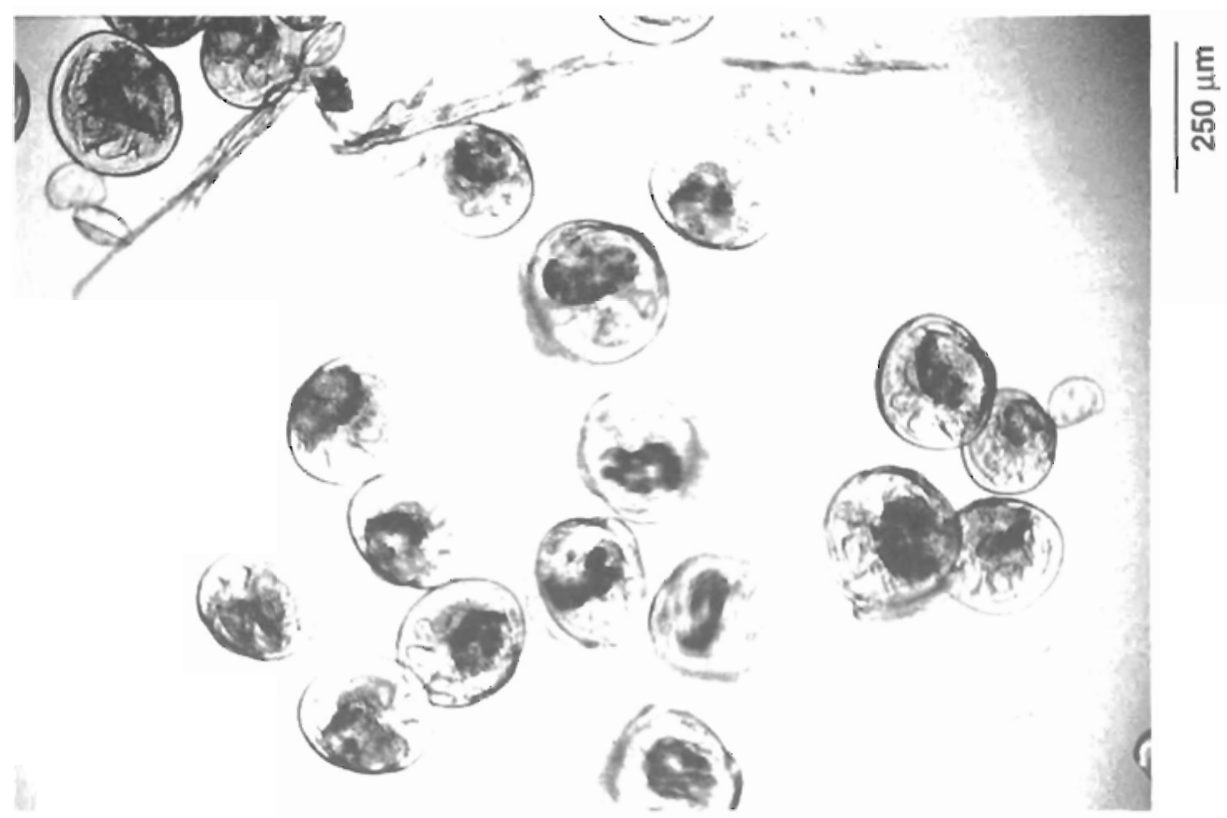

Photo 2.3. - Veliger larvae of M. edulis.

\section{Settlement and growth}

The pediveliger is the settlement stage of the mussel. It sinks to the sea bottom and starts crawling with its foot, searching for some filamentous structure such as algae or hydroids. The pediveliger prefers to attach to filaments in the first stage of settlement (e.g. upon the byssus threads of already settled mussels). Pediveligers then metamorphose to plantigrades. Later in the year, the plantigrades may leave the primary settlement sites and, again in the plankton, search for permanent sites, which are usually firm or hard surfaces. These late stage plantigrades (Photo 2.4) are called spat when they have completed their second larval settlement, at which point they are considered to have metamorphosed into miniature adults (Fig. 2.3). At this stage they are between 0.9-1.5 mm in length, so there is hardly any possibility of removing them by filtering the incoming cooling water.

Natural spat densities of the order of $6 \times 10^{5} / \mathrm{m}^{2}$ have been found but more usually they are in the range 1-2. $\times 10^{5} / \mathrm{m}^{2}$ (Dare, 1973). In power stations few data have been collected, but at Maasvlakte power station near Rotterdam numbers ranging from 50 to $2 \times 10^{5} / \mathrm{m}^{2}$ were recorded between May and August 1981. Population density is normally limited by the availability of solid substrate for spat settlement: cooling water systems with their concrete walls are an ideal subs- 


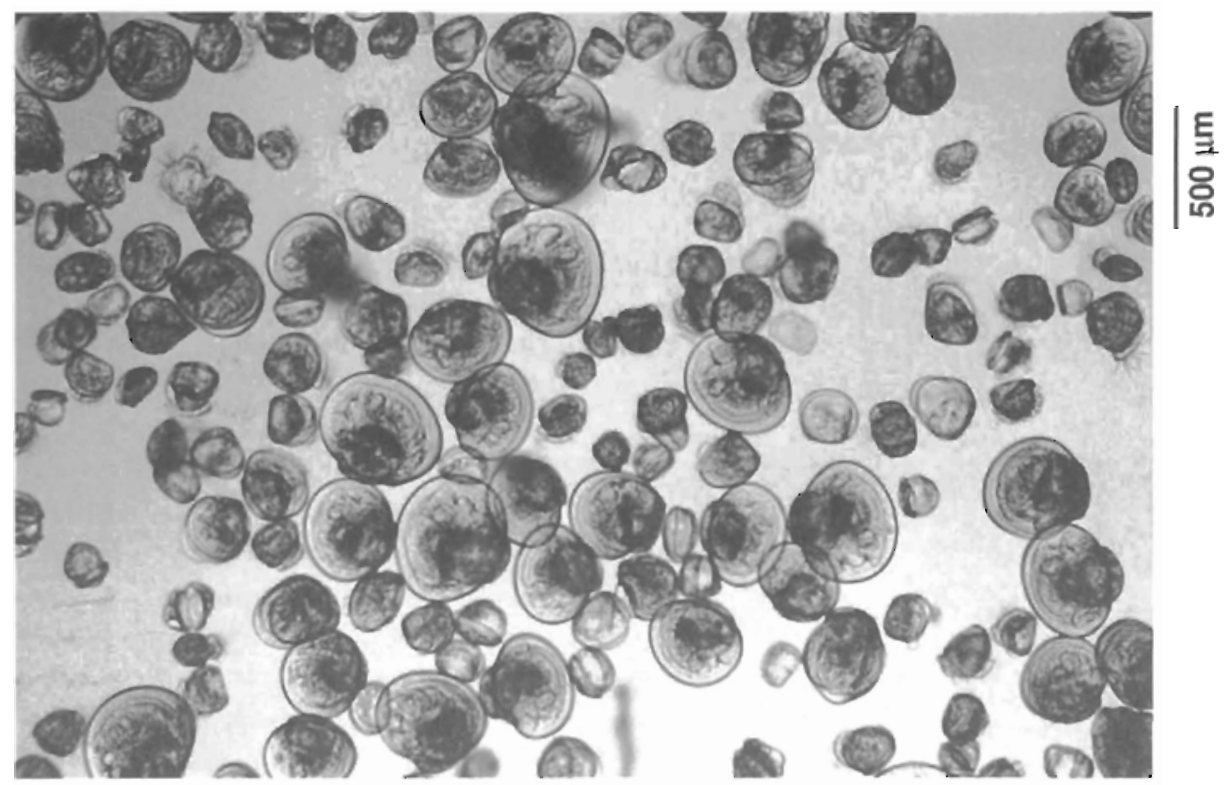

Photo 2.4. - Mytilus edulis larvae with late stage plantigrades or 'spat'.

trate for mussels. This artificial habitat is also ideal due to continuous flow, food, oxygen, the absence of predators and emersion. The important issue for operators is knowing when settlement occurs in cooling systems. At some sites, this may be over a distinct period of a few weeks in Spring, but it may elsewhere take place at any time of the year. The period of spatfall is generally geographically determined.

Unless settlement is quickly identified, it is possible for the spat to grow unnoticed to a size where they may interfere with functioning of particular parts of the station. For example, very little growth is required before the mussels reach a size equal to the interplate gap of plate heat exchangers, at which point blockage may occur. When mussel fouling is known to pose a significant risk, it is essential to have some rigorous form of monitoring for spat settlement throughout the period in which the sea water temperature is at or above $12{ }^{\circ} \mathrm{C}$. Spat settlement monitors have been used by EDF, KEMA and British Energy to detect settlement and also to verify the efficacy of the treatment regime.

Settling periods at Gravelines have been determined with a spat settlement monitor (Travade \& Khalanski, 1986). In 1983, the main settlement period was at the beginning of June. with secondary peaks at the end of July and the beginning of September. In 1984 the main settlement was at the end of May with secondary peaks 


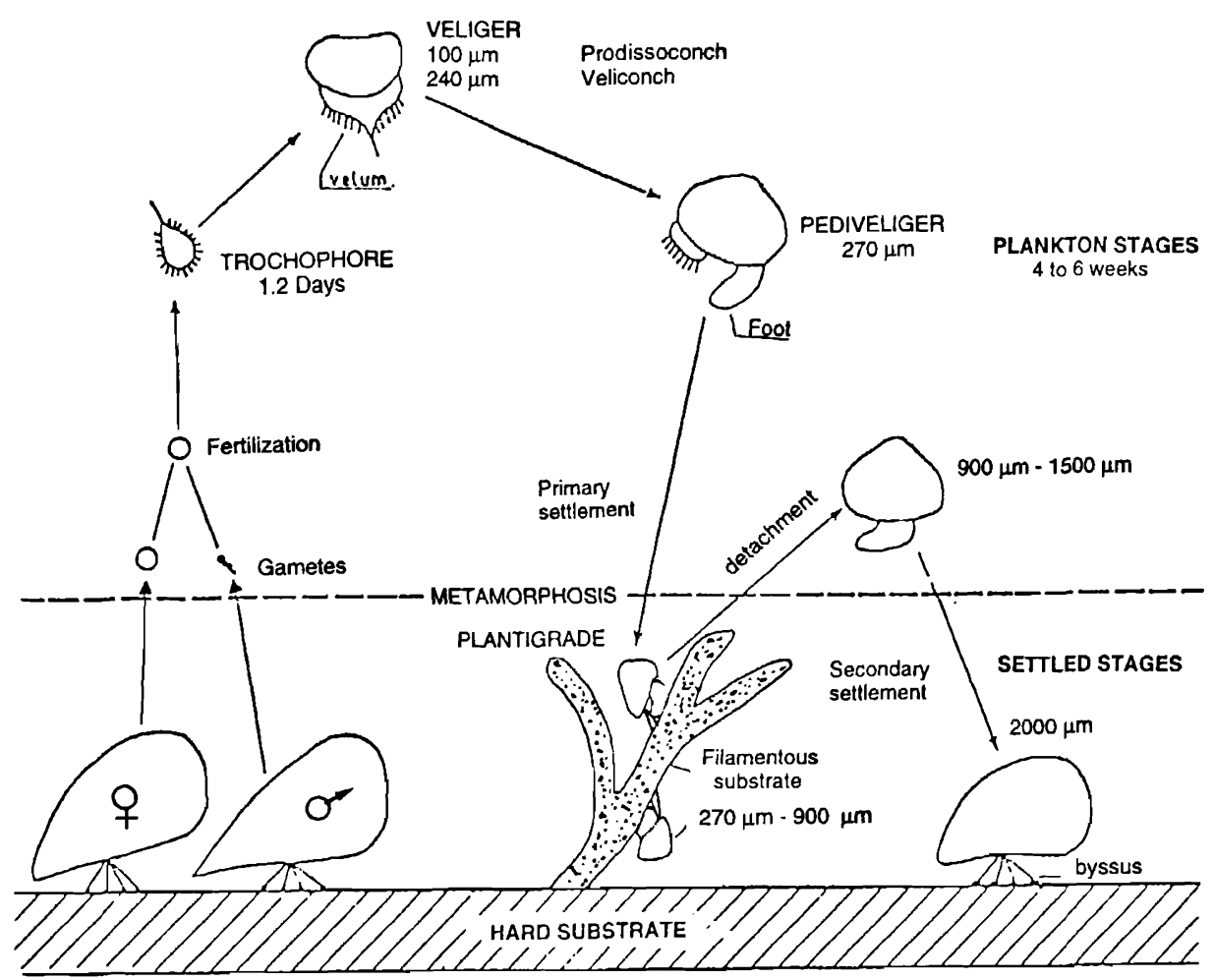

Fig. 2.3. - Biological cycle of $M$. edulis in the English Channel.

at the end of June and mid-October. The main settlement periods were seen to vary by several weeks from one year to the next. In the UK settlements have been recorded for most months in the year.

Mussel growth depends on water temperature. According to Bayne (ed.) (1976), growth does not start until the seawater temperature is above $12^{\circ} \mathrm{C}$. The same author reports that growth is seasonal, there being little in winter when the water temperature is below $10^{\circ} \mathrm{C}$. However, in practice, in some eutrophic coastal waters such as those at Le Havre or Dunkerque, growth is not negligible. The winter growth is greater for continuously immersed mussels than for natural populations located on the tidal shore that are submitted to daily emergence. The shell growth of mussel populations located below the tidal level (as in the CW systems) is rapid, and the shells of these populations are thinner than shells of nearby intertidal populations.

In these populations, below $10^{\circ} \mathrm{C}$, a significant growth takes place (Fig. 2.4). The effect of water tempe- 


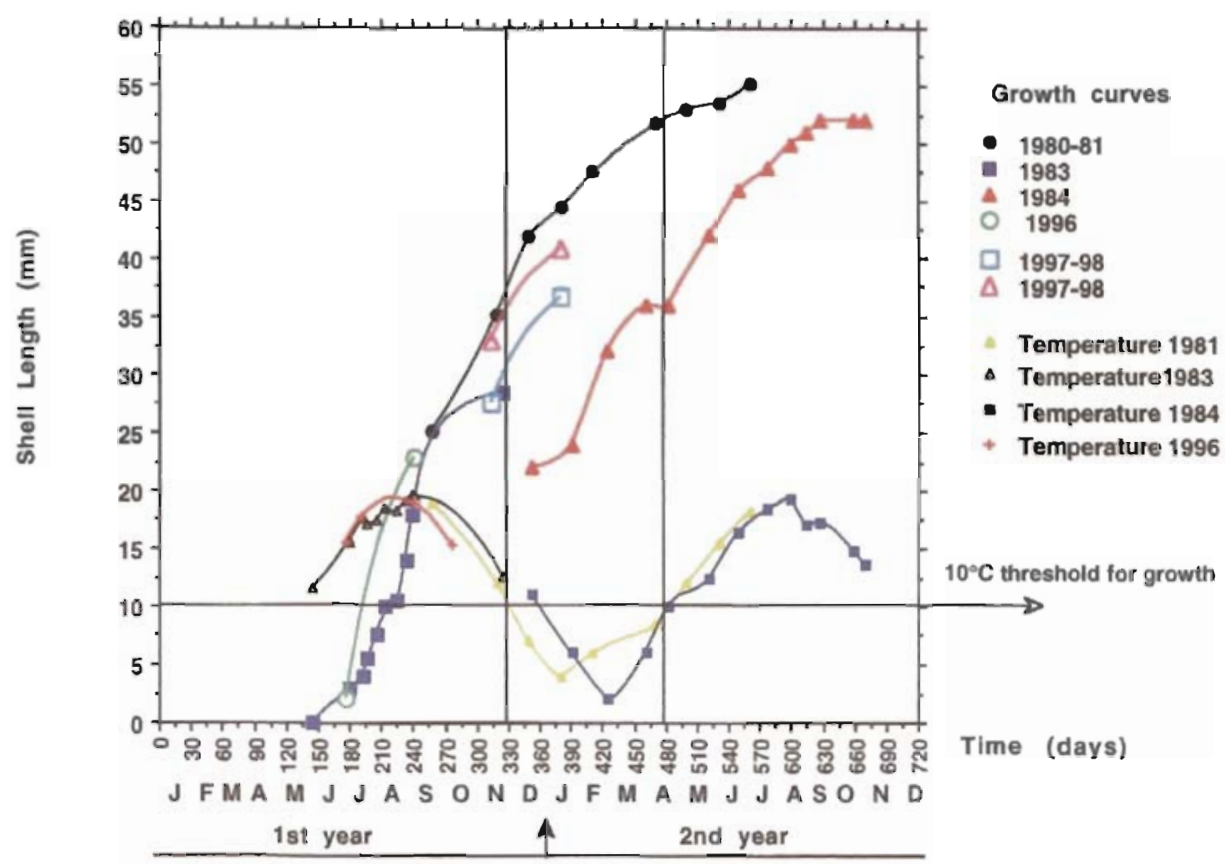

Fig. 2.4. - Growth of Mytilus spat in the intake canal of the Gravelines Nuclear Power Station according to shell length measurements made from 1980 to 1998.

rature, as distinct from season, on the growth rate of mussels have been observed by comparing growth in the intake and discharge channels at Gravelines over 1983-1984 :

- In winter, mussels placed in the outfall channel, where the water is heated to about $10^{\circ} \mathrm{C}$, the growth was $20-25 \%$ greater than that in the intake channel.

- When the water reached a temperature of $18-20^{\circ} \mathrm{C}$ in the outfall channel the growth was strongly reduced by comparison with that in the intake channel.

It is evident that growth in the unheated parts of cooling systems of po- wer stations is as good as the best recorded in natural populations. Because of this ability to grow very rapidly, spat can reach a size where they can lodge in condenser tubes within one year of settlement. in the intake channel at: Gravelines Power Station the average shell length was recorded in the range of $20-30 \mathrm{~mm}$ in November 1983, six months after settlement. Heavy settlement densities had been followed by rapid shell growth, with a maximum of $10 \mathrm{~mm}$ in 30 days. One year later in November 1984 the average length was $55 \mathrm{~mm}$ (Travade \& Khalanski, 1986).

Growth also depends on food availability (see Gosling (ed.), 1992). The 
high plankton production on the North Sea Coast is responsible for that very high growth rate during the summer months.

In general it may be said that the most favourable conditions for the settlement and growth of Mytilus spp. are :

- A water velocity between 0.2$1.6 \mathrm{~m} / \mathrm{s}$;

- An annual thermal regime in which the temperature is between 10 $18^{\circ} \mathrm{C}$ for long periods;

- water rich in plankton, dissolved organic and particulate matter;

- Permanent immersion in water, no low tide exposure;

- Rough substrates, either from barnacle settlement or the natural surface of concrete:

- The presence of other mussels making the intake suitable for the settlement of mussel larvae;

- The lack of the main predators, shore crabs (Carcinus sp.) and wading birds.

These various conditions, where food, oxygen supply and substrate availability are essentially non-limiting, are typical of most culverted cooling water system.

This ecological profile explains the presence of mussels in all cooling circuits using sea water, especially in the intake channels, tunnels and culverts, on steel bar screens, concrete culverts and the walls of rotating screen chambers. They are absent from channels and tunnels with high water velocities or heated discharges.

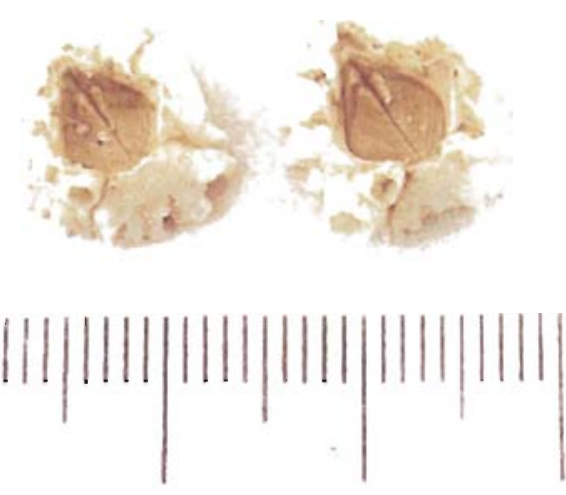

Photo 2.5. - Barnacle species Banalus crenatus from the intake canal of the Gravelines nuclear power station on the French North Sea coast.

The biology of marine mussels is comprehensively reviewed by Bayne (ed.) (1976) and Gosling (ed.) (1992). They present much of interest, particularly the information on the evolutionary flexibility of these species.

\subsubsection{Barnacles}

\section{Taxonomy and distribution}

Barnacles are members of the Sub-class Cirripedia, a highly modified group of the Class Crustacea. Thus they are related to Crabs, Lobsters and Shrimps. The main species found in cooling water circuits are $\mathrm{Ba}$ lanus crenatus, Balanus improvisus, Chthalamus stellatus, Semibalanus. balanoides and Elminius modestus, (Photo 2.5). Less commonly, The exotic Balanus amphitrite occurs in Zeeland, The Netherlands ans estuaries as in Shoreham Harbour Canal and 
Swansea Docks in the UK (Rainbow, 1984), where heated effluents are discharged from power stations. Most European species are small, of the order of 10-25 $\mathrm{mm}$ across the base and rarely more than $25-30 \mathrm{~mm}$ high; a contrast with some tropical species (e.g. B. tintinnabulum), which are ten times this size and cause serious operational problems for power stations.

Barnacles have a distinct zonation pattern on European rocky shores: Semibalanus balanoides is found midshore, with Balanus perforatus being found lower down. Balanus crenatus, is always found below the low water level, thus constantly immersed.

Reflecting this tidally driven distribution, Balanus crenatus is the most common species found in underwater circuits.

Most barnacles are stenohaline but $B$. improvisus is only found in estuaries including ports and brackish water.

\section{Biology and reproduction}

In adult life, barnacles are sessile organisms, fixed head-down on firm substrates. They look like truncated cones, the walls of which consist of overlapping calcareous plates. They are cemented to the substrate by the whole of the base plate, a modified head. Feeding is by means of the four to six pairs of legs, found inside the plated cone. The legs extend rhythmically to beat outside, creating a current of water flowing through the legs allowing planktonic particles to be filtered off as food.

Barnacles are hermaphrodite, having both male and female sex or- gans. Fertilisation is internal. Eggs are laid inside the external plates and hatch to give a free swimming shrimplike larva, the nauplius. These develop through several moults to become bivalved cypris larvae (Photo 2.6). Each cypris moves onto a firm surface, fixing itself by its head and antennae. The larva then develops the various adult characteristics.

\section{Settlement and growth}

In the English Channel, off the coast of Normandy, the release of larvae of the barnacle Semibalanus balanoides continues throughout the year with maximum abundance of the cypris larvae from March to May. The main settlement period is in MarchApril (Plessis-Fraissard, 1961).

The range of monthly mean temperatures at the time of the peak settlement of barnacles at Flammanville (1986-93) was $9^{\circ} \mathrm{C}$ in March and $10^{\circ} \mathrm{C}$ in April (Dreves et al., 1994).

At Penly power station, there are two naupliar peaks, one in spring, the other from July to September (CNEXO 1983). The first peak is of $S$. balanoides the second of $B$. crenatus. In 1996, the first settlement of barnacles occurred between April 5 and April 11 at a water temperature of $8^{\circ} \mathrm{C}$. The first settlement peak was recorded at the end of April at $10^{\circ} \mathrm{C}$. Settlements have been observed up to 1 st of October. The population at end of August is dominated by Balanus crenatus with a maximum heigth of $11 \mathrm{~mm}$ and a basis diameter of $4 \mathrm{~mm}$. The biomass of settled organisms, mainly bar- 


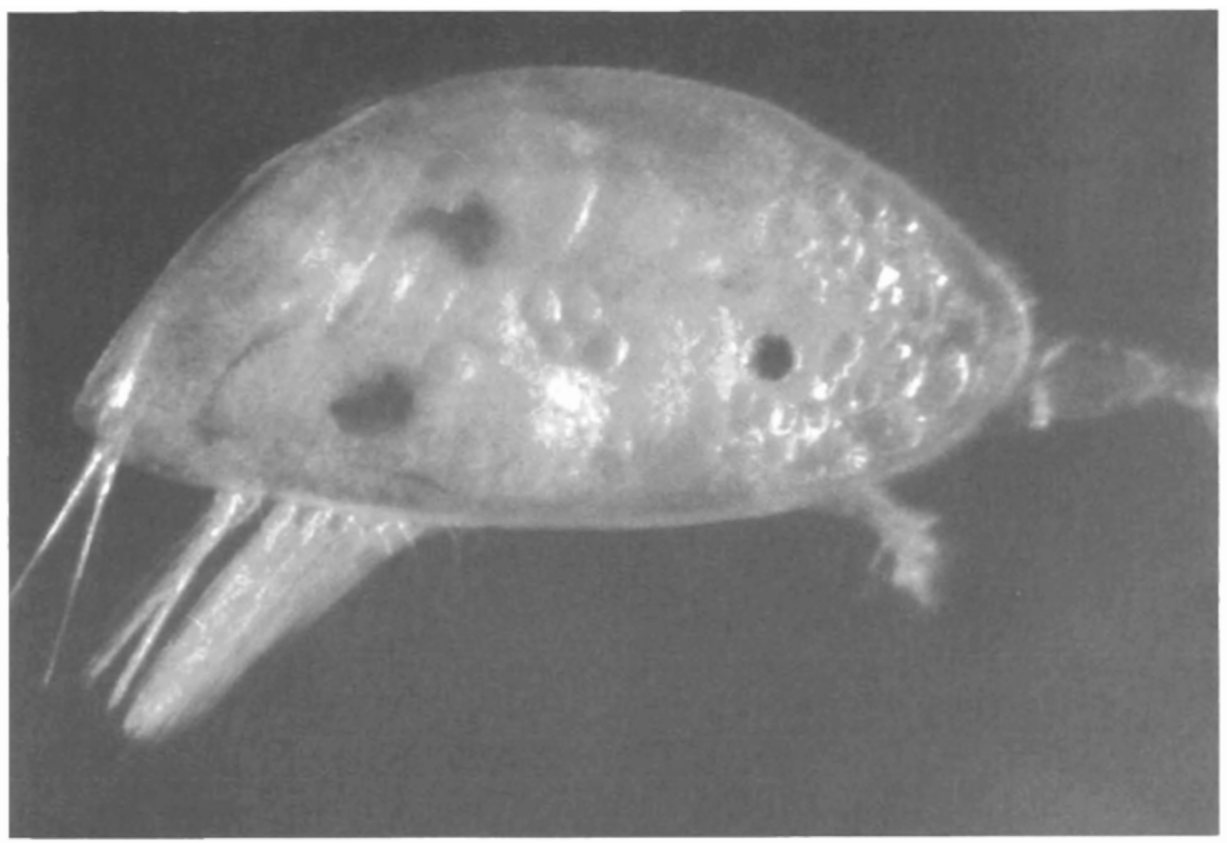

Photo 2.6. - Cypris larva, the planktonic settlement stage of barnacles.

nacles, on the PVC collector reached $27 \mathrm{~kg} / \mathrm{m}^{2}$ on August 27.

Monitoring of fouling organisms at Gravelines on the North Sea in 198384 showed massive settlement of $B$. crenatus in the first two weeks in May at a water temperature of $11^{\circ} \mathrm{C}$. One month later, in June, the PVC collecting plates were covered with a layer of $\mathrm{Ba}$ lanus crenatus several cms thick. The wet weight was estimated at $7.5 \mathrm{~kg} / \mathrm{m}^{2}$.

Barnacles may settle and develop on any surface exposed to seawater from culvert walls to rotating drum screens. As mussels, they tend to be very much less successful in colonising surfaces exposed to high rates of flow or particulary high temperatures. Dead individuals, or rather their calcareous plates, fall to the bottom of culverts and these debris can be washed downstream and cause signi-ficant problems to filters and heath exchangers.

\subsubsection{Other Organisms}

\section{Oysters}

Oysters (Ostrea edulis and Crassostrea virginica (Portugese), C. gigas (Japanese)), like mussels, are members of the Anisomyaria. However, the foot is smaller and the sexes are not separated. The shells are asymmetrical with one valve normally more concave than the other. The concave valve is firmly cemented to its substrate while the other valve provides a lid. 
The shell is externally ridged and shows a greyish-green colour. Its surface texture is stratified, noticeable more pronounced in adults, which gives the impressions that they are formed of sheets or layers of calcareous material. It measures between 7-10 $\mathrm{cm}$ and the inside is smooth and has a pearly, whitish, shiny colour with a violet mark. Inside the mantle, which lines the shell, are the four circular membraneous gills. These have many cillia which generate a current which enables water to pass through them carrying oxygen for respiration and micro-organisms for their food supply. Like other bivalves, oysters can close their shells tightly for long periods which enables them to resist the effects of toxic substances in the water.

Oysters are hermaphrodite but their sex does not develop at the same time. Individuals first become male, later female. In summer the male sexual products are shed into the water and fertilize the ovum of the females. About one to two million eggs are fertilized and deposited in the gills of the female. The development stage in the gills lasts between one to two weeks after which the larvae are released. This planktonic stage lasts for two to three weeks, when they metamorphose and sink to the bottom seeking a suitable substrate to settle. This part of the life stage happens at water temperatures of at least $18^{\circ} \mathrm{C}$.

The oysters, which arrive by swimming as veliger larvae in July and August, attach themselves to the walls of cooling conduits especially in areas

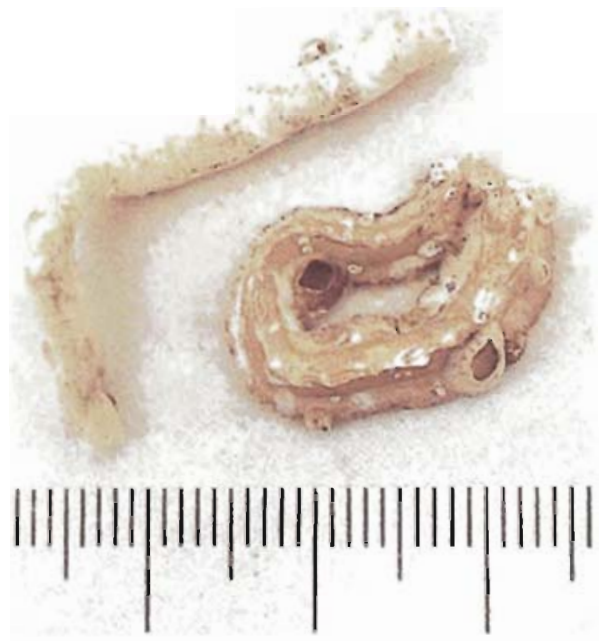

Photo 2.7. - Calcareous tubes of marine worms Pomatoceros triqueter (left) and Protula tubularia (right). Photo Studio Yves (Chatou). Main div. $=1 \mathrm{~cm}$.

with lower water velocities. With continuous chlorination most of the oysters will die and the upper valve will detach and may block condenser tubes and/or sieves. In general oysters require higher chlorine (hypochlorite) doses to kill them than mussels, but in the case of chlorine dioxide the dose is equal. The only serious case of fouling by oysters is known from a chemical plant in the Western Scheldt, the Netherlands.

\section{Tubeworms}

This include a variety of species of polychaete Annelids living in tubes, forming encrusting colonies which reduce water flow in culverts and can only be removed by mechanical means. Several fouling species, with calcareous tubes are found in power 


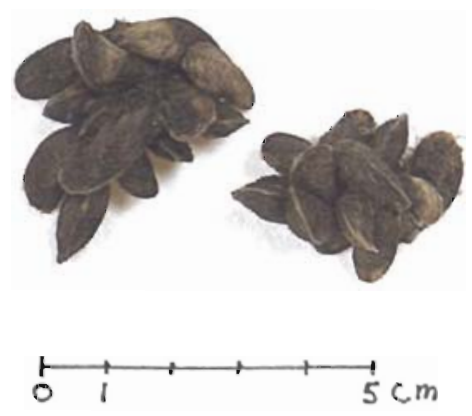

Photo 2.8. - The brackish water mussel : $M y$ tilopsis leucophaeata.

station cooling systems, including Serpula vermicularis (about $7 \mathrm{~cm}$ long) Protula fubularia (to $5 \mathrm{~cm}$ long. Pomatoceros triqueter with a triangular tube (photo 2.7), Hydroides norvegica, Salmacina tribranchiata (Filograna implexa) are smaller (maximum length of 2.5 to $3.0 \mathrm{~mm}$ ), but also form encrusting colonies which are difficult to remove. They are distributed in the Mediterranean, the AtIantic, The English Channel, the North Sea, and the west coast of the Baltic sea.

Tubeworms are less significant than barnacles in terms of their contribution to the debris which accumulates at the bottom of culverts and water chambers.

\subsection{Estuarine fouling}

Estuarine fouling is something of a special case. Firstly, the species di- versity found in estuaries is more limited than in nearby coastal waters. The species present are those tolerant of high turbidity and variable water quality, making them particularly robust fouling species. Secondly, estuaries provide a potential habitat for opportunistic alien species.

\subsubsection{Brackish water mussels}

\section{Taxonomy and distribution}

The Brackish water mussel, Mytilopsis leucophaeata (Photo 2.8), is a bivalve in the Family Dreissenidae. The Brackish water mussel and the Zebra mussel are thus taxonomically closely related. Previously, Mytilopsis leucophaeata was known as Congeria cochleata, and was introduced into Belgium from the subtropical Caribbean in the early part of the 19th Century (Marelli and Gray, 1983). Currently it is found along the coast of the North Sea from Germany through The Netherlands and Belgium into France and recently in Great-Britain (Oliver et al., 1998). The only' recorded cases of fouling are in The Netherlands, where it causes problems in the Velsen and Hemweg power stations which draw cooling water from the Noordzeekanaal (Jenner \& Janssen-Mommen, 1993; Rajagopal et al., 1994).

\section{Biology and reproduction}

This species is reported to be able to live in a wide range of intermediate salinities but not full sea water (Siddal! 1980). Mussels of a length of $2.4 \mathrm{~mm}$ 


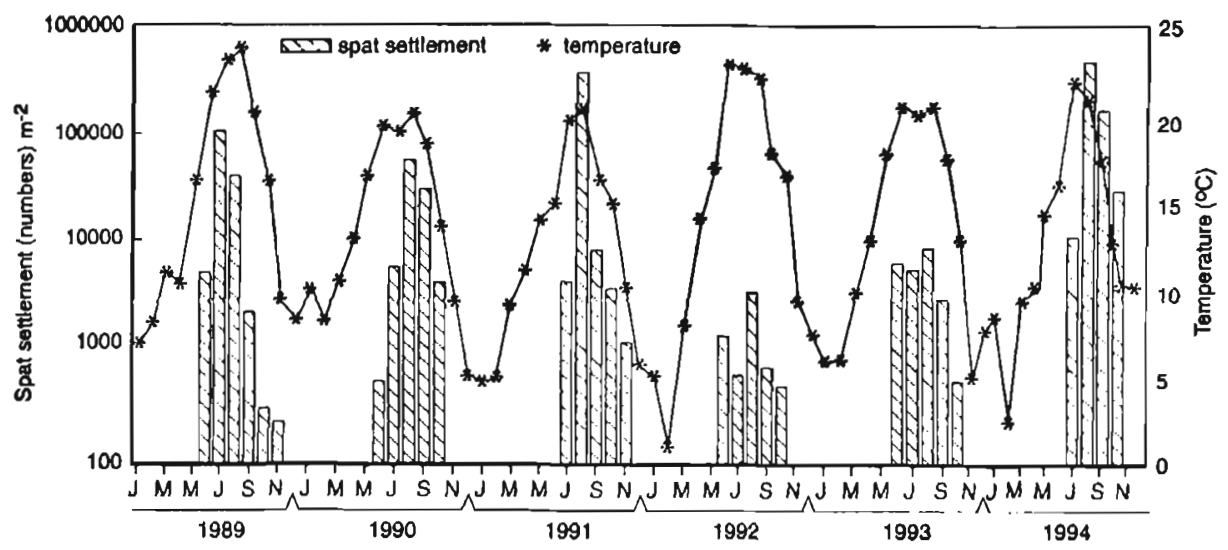

Fig. 2.5. - Seasonal variations in the spat settlement of $M$. leucophaeata on experimental PVC - panels and water temperature in the Noordzeekanaal during the years 1989-1994 (Rajagopal et al., 1994).

are occasionally found to be sexually mature but generally the mean size of sexually mature specimens is $>7.0$ $\mathrm{mm}$ when the mussels are about two months old. Spawning in the Noordzeekanaal has been observed between June and September when the water temperature is at or above $20^{\circ} \mathrm{C}$, and salinity is at its highest. This mussel has a planktonic veliger as its larval stage and the settled stages become attached by byssus threads. Densities of veligers in the Noordzeekanaal has been observed in the order of $15000 / \mathrm{m}^{3}$.

\section{Settlement and growth}

Spat settlement densities on panels located in the intake of the Velsen power station have been up to $6.5 \times 10^{6} / \mathrm{m}^{2}$ whereas spat settlement densities on panels in the canal (Fig. 2.5) showed maximal values of $0.5 \times 10^{6} / \mathrm{m}^{2}$. Spat settlement in the canal is related to water depth, with a maximum at $2 \mathrm{~m}$ and lower densities at $1 \mathrm{~m}$ and $3 \mathrm{~m}$ depths. There was no depth variation in settlement density in the power station intake. One month after settlement, these mussels are $3 \mathrm{~mm}$ in length; they can reach $14 \mathrm{~mm}$ at the end of their first year.

\subsubsection{Barnacles}

\section{Taxonomy and distribution}

The taxonomic status of barnacles has been described in section 2.23.2. The only estuarine species, Balanus improvisus (see Photo 2.5) has a wide distribution, being found in Europe (Furman \& Yule, 1991) including the Baltic and the Eastern USA.

\section{Biology and reproduction}

This species is euryhaline and is found in a range of salinity from $5 \%$ 。 to $15 \%$, and occasionally lower. Ge- 
nerally, it is not found where salinity is above $25 \%$ (Rainbow, 1984); although Barnes (1994) suggests a salinity up to $35 \%$ o. As with all barnacles, $B$. improvisus is hermaphrodite but usually reproduces by cross fertilisation. However, when adult density is such that the individuals are more than $3-5 \mathrm{~cm}$ apart then self fertilisation takes place. Several broods are produced per year at intervals of six weeks. The release of nauplii starts when the water temperature reaches $10^{\circ} \mathrm{C}$ and stops when the temperature falls below that threshhold.

\section{Settlement and growth}

$B$. improvisus can settle on both concrete and steel structures. They are reported as preferring rough surfaces (Barnes, 1971). At the time of settlement, the presence of one or more settled cyprids leads to settlement of large numbers of the same species (Clare et al., 1994). This behaviour is also stimulated by the presence of adults of the same species (Marchand \& Denayer, 1991).

Settlement has been found to start in the Noordzeekanaal (The Netherlands) during June/July, with maximum densities in the region of the intake at Velsen power station of $37,200 / \mathrm{m}^{2}$ in July 1994 . The effect of the water intake was to promote a heavier settlement at $2 \mathrm{~m}$ depth, in mid water. A second spawning started during September/October and ended in November. The maximum settlement density was of the same order as that found by De Wolf (1973).
Growth of B. improvisus at Velsen power station was monitored on settlement panels and showed a basal diameter of $10-11 \mathrm{~mm}$ after 45 days.

\subsubsection{Other organisms}

\section{Tube Worms}

The tube worm Ficopomatus enigmaticus (syn. Mercierella enigmatica), is one of two others currently recorded as causing problems for power station cooling systems. This is an immigrant species which originally was found in subtropical regions; it probably derived from Australia or the subtropical Australian region (Allen, 1953; Dixon, 1981). It was first recorded in Europe by Fauvel in Normandy in 1921, and then found in the London docks in 1922. It is now found in the Mediterranean, the harbour at Vlissingen (Flushing, SW Netherlands), the Noordzeekanaal (near Amsterdam and Velsen) in Cavendish Dock, Barrow-in-Furness (UK), Roath Basin, Cardiff docks, South Wales together with Mytilopsis leucophaeata (Oliver et al., 1998). The interesting point about Cavendish Dock is that $F$. enigmaticus and $B$. improvisus both colonized the dock in the same year, 1959 , after a period of two years in which the salinity was, on average, below $10 \%$. (Markowski, 1962). The tube worm formed a thick lining in the intake cooling water pipes, which had to be cleaned manually from time to time.

F. enigmaticus is a euryhaline species living in salinities from 1-35\%; larval development is best at salinities 
between $10-30 \%$ and inhibited below $6 \%$ (Hartmann-Schroeder, 1967). Below $2.0-3.0 \%$ chlorinity, no reproduction takes place and there is high mortality after a long time at such chlorinity levels (Wolff 1969a). Low salinities reduce growth of the calcareous tubes because of the lowered calcium concentrations in fresh water (Straughan, 1971). Settlement takes place on most substrates, but preferably in waters without low current speeds, as this species is unable to withstand deposition of mud. The larvae settle and metamorphose and may reach a tube length of $30 \mathrm{~mm}$ within 16 days (Ten Hove \& Van den Hurk, 1993).

In the Noordzeekanaal, the first settlement of $F$. enigmaticus was observed in the summer of 1991, followed by an increasing intensity of settlements after 1992. Settlement occurred from July to August, when temperatures $>15^{\circ} \mathrm{C}$ and salinity $>5 \%$. The resulting settlement densities were $64 \times 10^{3} / \mathrm{m}^{2}$, recorded on PVC panels in October 1993 after 160 days of exposure. There was intense competition for settlement space with both M. leucophaeata and Cordylophora caspia the result of which appeared to be a reduction in overall growth. The newly settled tube worms grew at a rate of $10 \mathrm{~mm} /$ week for the first 4-6 weeks but only reached a size of $60-70 \mathrm{~mm}$ by the end of the first year (pers. obs.).

Fouling by tube worms is strongly dependent on water velocities, high settlement is to be expected at velocities below $1 \mathrm{~m} / \mathrm{s}$. Old encrustations of dead tube worms will serve as substrate for new ones, which can lead to a firm crust up to $30 \mathrm{~cm}$ of thickness in six years. It is obvious that these encrustations serve also as a perfect substrate for mussels and other hydroids (Photo 2.9).

\section{Hydroids}

Cordylophora caspia is the main hydroid species causing fouling problems. It is a colonial hydroid found in brackish or estuarine waters and in fresh waters with often changing salinity or modified ionic conditions (Arndt, 1973; Kinne, 1956). This is an animal belonging to the same part of the animal kingdom as Sea Anemones, Jellyfish and Corals. It has a wide but discontinuous distribution throughout Europe, Asia, North and South America and Australasia.

Reproduction is by asexual budding of small colonies or from pieces of the basal attachment mesh or hydrorhiza called menonts. Growth is also by budding so the production of new colonies and increase of the size of the colonies is by the same process. As colonies usually die back in the winter, regrowth in the spring is from hydrorhizal pieces.

Colonies develop in brackish water with a salinity of $0.2-10 \%$, but there is a wide variation in the temperature and salinity conditions for optimal growth (Vervoort, 1946, Arndt, 1965; 1973; 1984; and Kinne, 1956). In the Noordzeekanaal, since 1986 it has been observed that these hydroids are the first colonisers of the fouling panels and attachment starts in May 


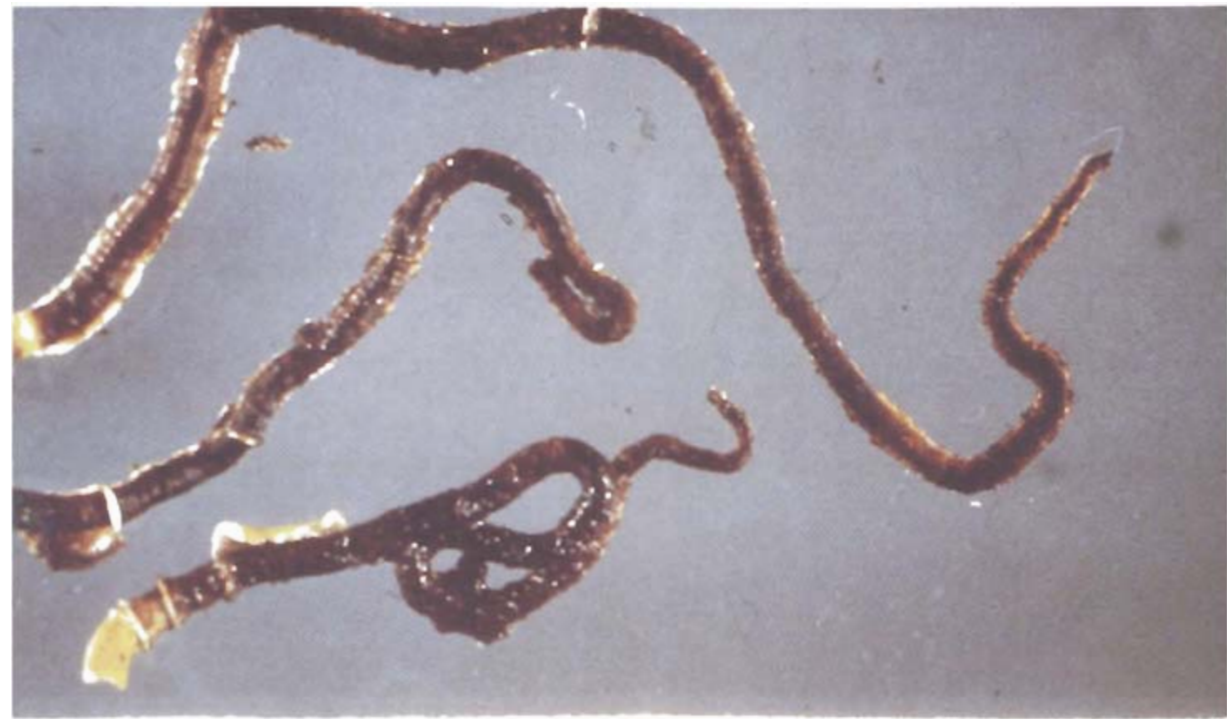

Photo 2.9. - Ficopomatus enigmaticus, showing the individual worms and the natural aggregations of worms (with M. leucophaeata) as found in cooling systems.

and finishes in October. These primary settlers are subsequently covered to various degrees by the brackish water barnacles and mussels. However there is a strong interaction between $F$. enigmaticus and the colonial-hydroid, Cordylophora caspia, as the latter prevents the settlement of the former by causing great accumulations of mud.

Similar observations have been made at Cattenom Power Station on the river Moselle, where Cordylophora is amongst the first organisms to settle in April. As this species grows it covers all the walls of the intake culverts and chambers and is in turn a suitable substrate for settlement by the Zebra mussel (Dreissena polymorpha) (Moreteau \& Khalanski, 1994).

\subsubsection{Microbial fouling}

The development of microbial fouling on surfaces in cooling systems depends on two features, the materials of the cooling system and the quality of the water. The materials affect the speed at which organic molecules and bacteria colonise the surfaces. Water quality controls the rate of growth, the 3-D architecture of the microbial community and thus the ultimate thickness of the slime layer. It is the rate of growth of this layer 
which determines the type and frequency of the treatment needed to control growth or to eliminate the slimes from condenser tubes.

In all environmental and power plant conditions, biofouling by microorganisms proceeds in a standard sequence: conditioning of the surface by attraction, adsorption and followed by adhesion of micro-organisms. The common species are those whose metabolism causes the release of extracellular metabolites called mucopolysaccharides. Recently, it has been a commonplace to replace copper alloy condenser tubes, with titanium steel tubes. These latter have a higher heat transfer coefficient but are colonized much more rapidly by slime-forming bacteria than the copper alloy tubes. The principles of bacterial effects in power stations are the same in marine, brackish and fresh waters.

\subsection{FRESHWATER FOULING}

Power stations sited on rivers, lakes or reservoirs may be directly-cooled where there is an adequate supply of water, as for example the River Rhine, in Germany and The Netherlands, the river Rhône in France, or they may need to be tower assisted where the water flows are lower, as on the River Trent, in England. Tower assisted cooling is also needed to avoid excessive temperatures in the receiving water, as with inland nuclear stations in France and all inland rive- rine stations in England. Should the discharge cause the water temperature to exceed the limits defined in the Freshwater Fisheries Directive (EEC 1978), then obviously the choice would be that of a tower assisted circuit. The impact of fouling on the performance of the power station differs greatly between the direct and indirect cooling systems. A wide variety of organisms are found and a useful description of them has been given by Callow (1993).

\subsubsection{Directly cooled circuits}

\section{Zebra mussels}

\section{Taxonomy and distribution}

The Zebra Mussel (Dreissena polymorpha), (Photo 2.10) is a freshwater bivalve mollusc, member of the Family Dreissenidae. It is widely distributed, where its current status has been aided by attachment to the hulls of boats and rafts used in the transportation of goods since 1760 (Kinzelbach 1992). Zebra mussels are now widely distributed throughout Europe, from the original area of the PontoCaspian to Britain and Ireland (recently), and from Sweden to the south of France and the Po river in Italy.

After the introduction of the Zebra Mussel in North America via ballast water since 1985-1986, two species have been identified: Dreissena polymorpha and Dreissena bugensis called the 'Quagga mussel' in the US and Canada. 


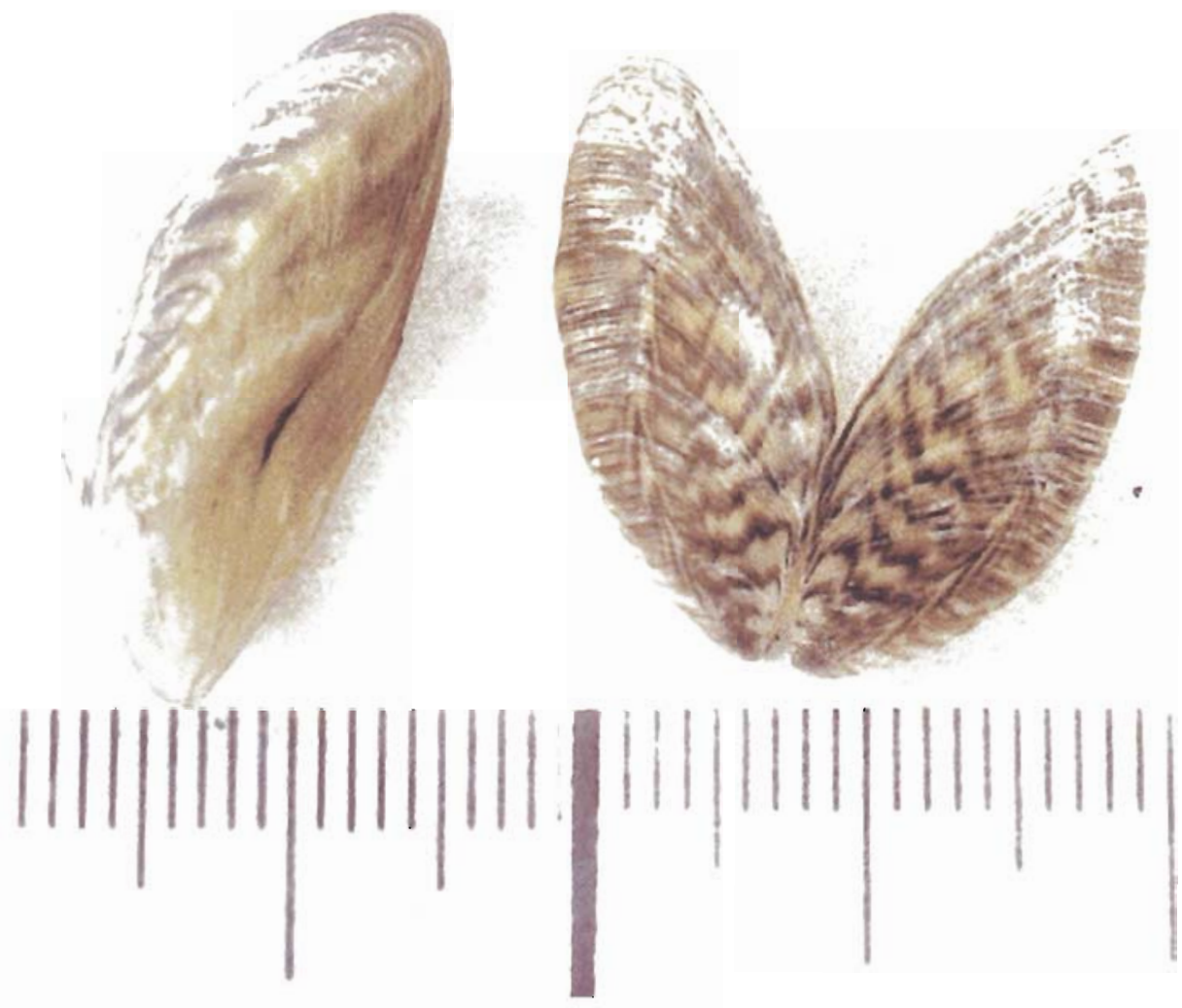

Photo 2.10. - D. polymorpha, adults. Main div. $=1 \mathrm{~cm}$.

\section{Biology and reproduction}

There is a vast European literature on all aspects of the biology of $D$. polymorpha. Much of the work is in Russian and references are listed in Schloesser et al. (1994), which aiso includes references to much published western European work. There have been many recent papers, conference proceedings and books covering the effects of this species on cooling water cricuits, municipal water treatment plants and also the ecolo- gical impact of the excessive spread of zebra mussels in North America. Most useful in this respect are the following: Proceedings of the International Zebra Mussel Conference (1991, 1992, 1993, 1994, 1995, 1996, 1997. 1998); EPRI (1992), Neumann \& Jenner (eds) (1992), Nalepa \& Schloesser (eds) (1993), Claudi \& Mackie (1994) D'Itri (ed), (1997), and Khalanski (1997a, b).

The most important features of the biology of this species with regard to 
fouling of power station cooling systems are the presence of a planktonic larval phase, the veliger, and the retention of the byssus thread system into the adult stage, enabling the adults to adhere in large numbers to hard surfaces.

The life cycle is divided into two phases, the larval and the adult. The adults, of separate sexes, release eggs and sperm into the surrounding water; after fertilisation and completion of the embryological stages, the eggs hatch to release a free swimming larva, the veliger. Reproduction is continuous throughout that part of the year in which the water temperature is above $13-15^{\circ} \mathrm{C}$ but settlement appears to be confined to distinct phases, of which there are a maximum of three in a good year (Neumann \& Jenner (eds), 1992). Ion concentration required for fertilization and early stage development has been investigated by Lynn et al., 1997; there is no development at $\mathrm{Ca}^{++}<8.0 \mathrm{mg} / \mathrm{L}$, and development is reduced at $\mathrm{K}^{+}<0.39 \mathrm{mg} / \mathrm{L}$. This veliger grows to give rise to the pediveliger, the settlement stage, which attaches itself to firm surfaces by the secretion of byssus threads. The newly settled juveniles grow to become the adult.

Veliger larvae are found during the summer months when there are higher water temperatures and the food supply is much increased. In the River Moselle at Cattenom veligers are found from April up to August with two peaks occurring round Mid-June and the end of August (Moreteau \&
Khalanski, 1994). The time of first occurrence of veligers in the River Seine near Paris was strongly associated with a water temperature greater than $13^{\circ} \mathrm{C}$ (Testard, 1990). Similar data have been reported from the River Meuse (Gillet \& Micha, 1985) and the River Rhine (Jantz \& Neumann, 1992). Data from the Moselle show the highest veliger densities in any one year to be associated with water temperatures of $21^{\circ} \mathrm{C}$ to $24.7^{\circ} \mathrm{C}$ (Moreteau \& Khalanski, 1994).

The plankton larval stages duration also depends on the water temperature (Table 2.1). In spite of significant differences in the estimated time, all the data show that during the summer period, it requires at least two to three weeks between the spawning and the settlement. This biological feature implies that, in rivers, the settled mussels are generated by parental populations located upstream far from the location of settlement (Neuman and Jenner (eds), 1992).

\section{Settlement and growth}

The densities of newly settled mussels can be as high as $7 \times 10^{5} \mathrm{~m}^{2}$ during one breeding season, but because of competition for space and food the maximum adult densities are $2 \times 10^{5}$ per $\mathrm{m}^{2}$, more than enough to cause serious impairment of cooling system functioning. There is some variation in settlement density of the spat with geographical location. In the River Waal (1984/5), a branch of the Rhine in The Netherlands, 400-600 $/ \mathrm{m}^{2}$ were recorded but in the Hollandsch Diep, another branch of the 
Table 2.1. - Duration of the plankton stages in Zebra mussels depending on the water temperature.

\begin{tabular}{|c|c|c|c|c|}
\hline Species & Location & $\begin{array}{l}\text { Water } \\
\text { Temperature }\end{array}$ & $\begin{array}{c}\text { Time between } \\
\text { spawning and } \\
\text { settlement }\end{array}$ & References \\
\hline $\begin{array}{l}\text { Dreissena polymor } \\
\text { pha }\end{array}$ & $\begin{array}{l}\text {-ITwo lakes near } \\
\text { Köln (Germany) }\end{array}$ & $\begin{array}{l}15^{\circ} \mathrm{C}-20^{\circ} \mathrm{C} \\
16^{\circ} \mathrm{C}-24{ }^{\circ} \mathrm{C}\end{array}$ & $\begin{array}{l}28 \text { days } \\
18 \text { days }\end{array}$ & Sprung 1987, 1989 \\
\hline $\begin{array}{l}\text { Dreissena polymor } \\
\text { pha and } D \text {. bugen } \\
\text { sis }\end{array}$ & r-1Experimental data & $24^{\circ} \mathrm{C}$ & 15 to 20 days & Baldwin 1995 \\
\hline $\begin{array}{l}\text { Dreissena polymor } \\
\text { pha }\end{array}$ & -I-Experimental data & $20^{\circ} \mathrm{C}$ & 18 days & $\begin{array}{l}\text { Vanderpoeg et al., } \\
1995\end{array}$ \\
\hline $\begin{array}{l}\text { Dreissena polymor } \\
\text { pha }\end{array}$ & $r-1$ Experimental data & $22{ }^{\circ} \mathrm{C}$ & 21 days & $\begin{array}{l}\text { Seltzer-Hamilton } \\
\text { et al., } 1995\end{array}$ \\
\hline
\end{tabular}

Rhine, $16 \times 10^{3}-60 \times 10^{3} / \mathrm{m}^{2}$ the range was similar to that in the Ysselmeer $\left(16 \times 10^{3}-45 \times 10^{3} / \mathrm{m}^{2}\right)$ (Jenner \& Janssen-Mommen, 1993).

The biological cycle of this species is summarized on Figure 2.6. and data on settlement and growth of the zebra mussel in European rivers and lakes are reported in Table 2.2.

Growth varies with temperature, food supply and flow water (Jantz \& Neumann, 1992; Jenner \& JanssenMommen, 1993) and shows an increment rate which decreases exponentially with increasing length (Jantz \& Neumann, 1992; Moreteau \& Khalanski, 1994). In the first growth season after settlement $(0+) \quad D$. polymorpha shells may be expected to reach $15-16 \mathrm{~mm}$, a length equal to approximately $50 \%$ of the total growth over three years. Growth of mussels at Cattenom has been modelled showing that cohort growth depends on time of settlement (Moreteau \& Khalanski, 1994). The first cohort, corresponding to the first settlement peak in the year, gives growth of approximately $15 \mathrm{~mm}$ whereas the last cohort in that year gives a maximum length of $10 \mathrm{~mm}$ (Fig. 2.7).

The important point here is that mussels of $15 \mathrm{~mm}$ in length are likely to block plate heat exchangers and even condenser tubes if they are dislodged in clumps.

\section{Asiatic clam}

\section{Taxonomy and distribution}

The Asiatic Clam Corbicula fluminea is a fresh water bivalve mollusc of the Family Corbiculidae, recorded for the first time in 1924 (McMahon (1983) or 1938 in North America near the mouth of the Columbia River (Burch, 1944), and probably introduced in Europe in the second part of the 20th century. First observations in The Netherlands were made in 1988 in the western part of the River Rhine, but in the south of France and Portugal Corbicula fluminea was already 


\begin{tabular}{|c|c|c|c|c|c|c|c|c|c|c|c|c|c|c|c|}
\hline 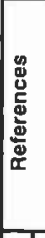 & & 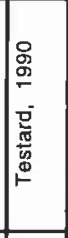 & 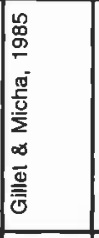 & 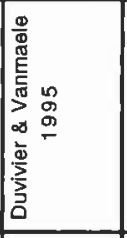 & 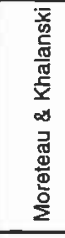 & 용 & & & 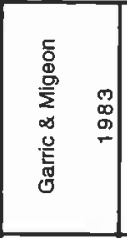 & 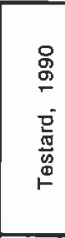 & & 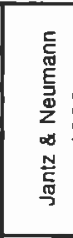 & 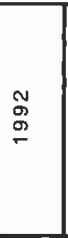 & 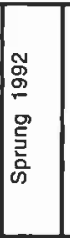 & 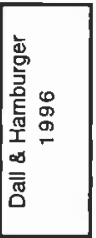 \\
\hline 하 & 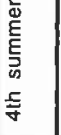 & $\mid \begin{array}{l}0 \\
\stackrel{0}{\infty} \\
\text { in } \\
\text { vi }\end{array}$ & & & & & & & & & & & & & $\begin{array}{c}\mathcal{N} \\
\wedge\end{array}$ \\
\hline 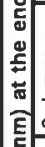 & 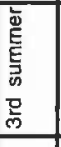 & 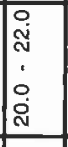 & & & & & & $\begin{array}{l}\infty \\
\stackrel{\infty}{2} \\
\stackrel{2}{\sim}\end{array}$ & & & & & & & 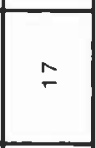 \\
\hline 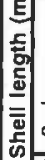 & 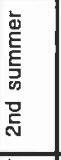 & 웅 & $\stackrel{0}{r}$ & & & & & $\begin{array}{l}\frac{1}{4} \\
\dot{N} \\
\vdots \\
\bar{N}\end{array}$ & $\stackrel{\circ}{\stackrel{\circ}{\circ}}$ & & 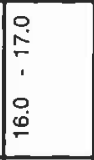 & & $\mid \begin{array}{ll}0 & 0 \\
\dot{U} & \dot{\sigma} \\
\tau\end{array}$ & & $\begin{array}{ll}0 \\
& 0 \\
& 0\end{array}$ \\
\hline 空. & 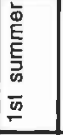 & $\mid \begin{array}{l}0 \\
\text { in } \\
1 \\
0 \\
\dot{q}\end{array}$ & & & & & & 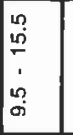 & $\begin{array}{l}\circ \\
\vdots \\
\dot{0} \\
0 \\
\infty\end{array}$ & & 足 & & $\left|\begin{array}{ll}m & 0 \\
\ddot{m} & \dot{m}\end{array}\right|$ & $\left|\begin{array}{cc}m & 0 \\
& \stackrel{m}{0}\end{array}\right|$ & $\overline{\mathrm{N}} \stackrel{\circ}{\mathrm{N}}$ \\
\hline 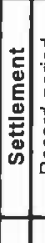 & 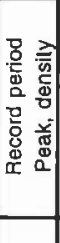 & & 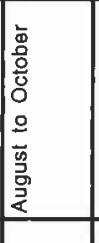 & 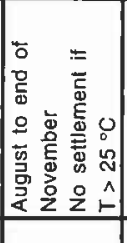 & 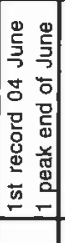 & 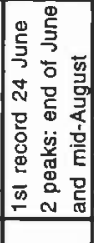 & 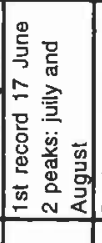 & 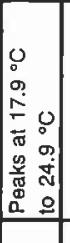 & 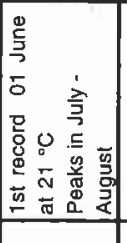 & & & & & & \\
\hline 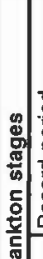 & 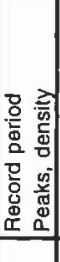 & & 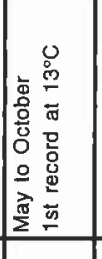 & 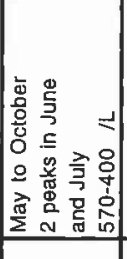 & 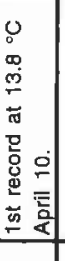 & 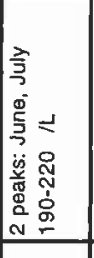 & 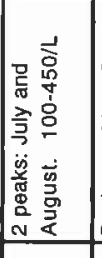 & 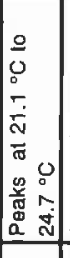 & 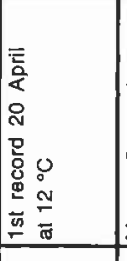 & 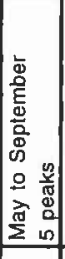 & 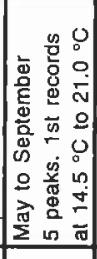 & 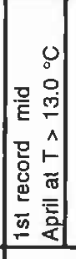 & & & 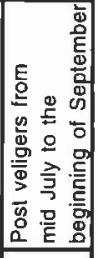 \\
\hline$\frac{\pi}{a}$ & $\begin{array}{l}\mathbf{\Phi} \\
\text { Ф }\end{array}$ & & $\begin{array}{l}J \\
\infty \\
0 \\
0\end{array}$ & $\stackrel{+}{\circ}$ & - & $\begin{array}{l}\text { N } \\
\sigma \\
\sigma \\
-\end{array}$ & $\begin{array}{l}9 \\
9 \\
0 \\
-5\end{array}$ & $\left|\begin{array}{cc}1 & 0 \\
\circ & 0 \\
0 & \circ \\
\hdashline & \circ\end{array}\right|$ & $\begin{array}{l}0 \\
\infty \\
\infty \\
\sigma\end{array}$ & $\left|\begin{array}{cc}1 & \\
0 & \infty \\
0 & 0 \\
\hdashline & 0\end{array}\right|$ & 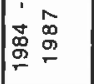 & 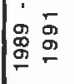 & & & $\mid$\begin{tabular}{ll}
0 & 9 \\
$\circ$ & $\stackrel{2}{\circ}$ \\
0 & 0 \\
\hdashline & 0
\end{tabular} \\
\hline 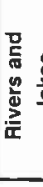 & 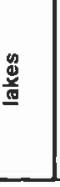 & 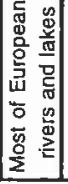 & 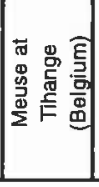 & 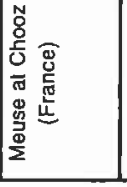 & & 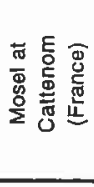 & & & 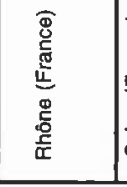 & 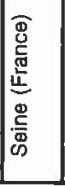 & 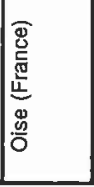 & . & 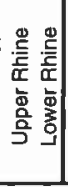 & 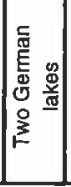 & 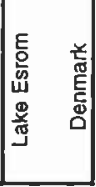 \\
\hline
\end{tabular}


present before 1988 (Mouthon 1981). In France the present distribution is: Garonne and tributaries (Lot and Tarn), Dordogne, Adour river basin, Aude and the canal du midi and the canal lateral à la Garonne, lower Loire, upper Rhône and the Moselle. This covers the south, the west and the north east. In addition Corbicula is found in the Rio Minho in Spain and the Rio Tejo in Portugal. The river
Rhine has populations of this species from The Netherlands as far upstream as half way along the German part of the river. The Asiatic clam is found in Belgium, in the river Meuse and in the canal Bocholt - Herentals; it has also invaded rivers in the UK. A second species is also found in some European rivers: C. fluminalis in the Rhine, the Weser and the French part of the Moselle.

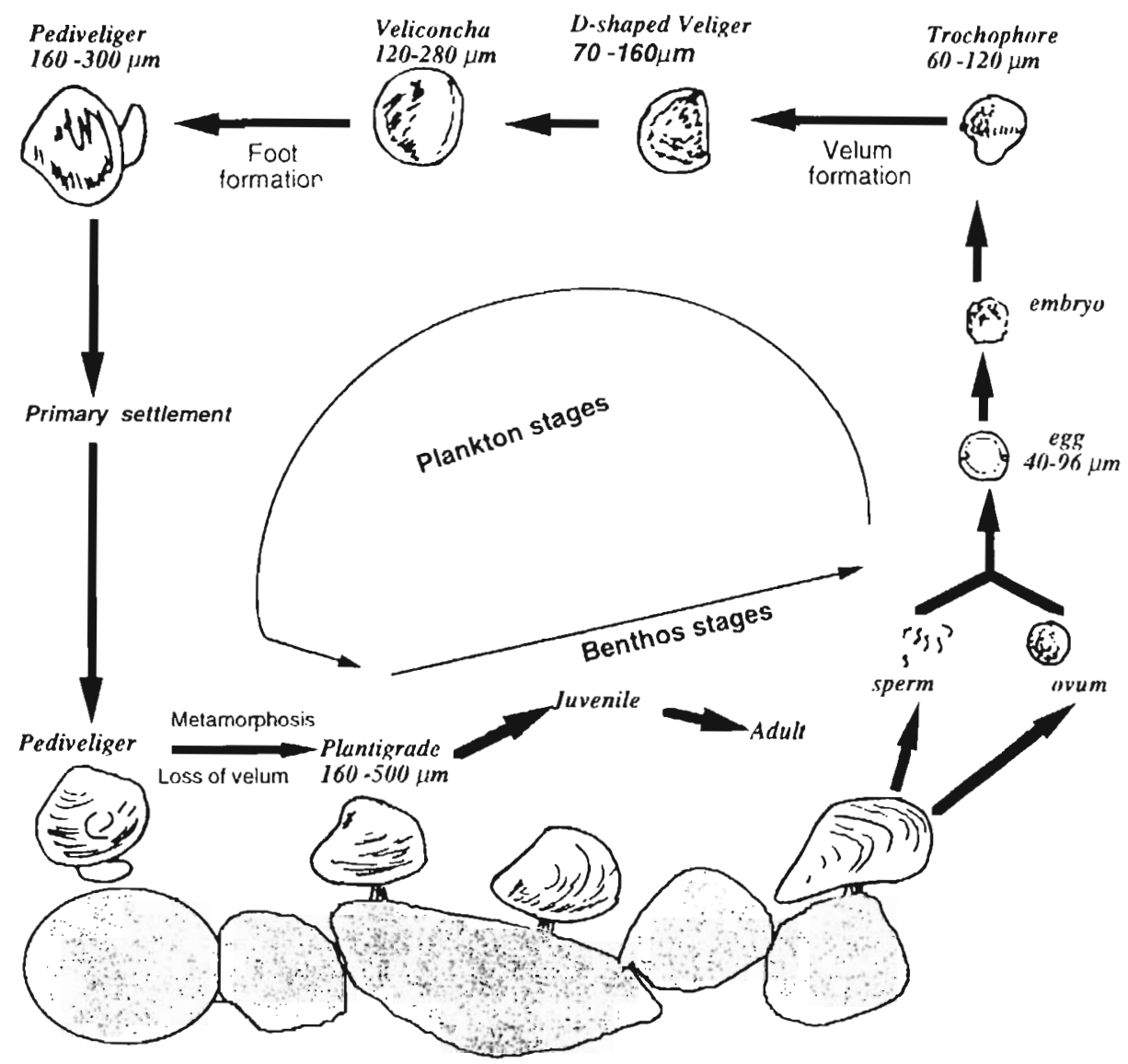

Fig. 2.6. - Biological cycle of Dreissena polymorpha, adapted from Ackerman (1995) 


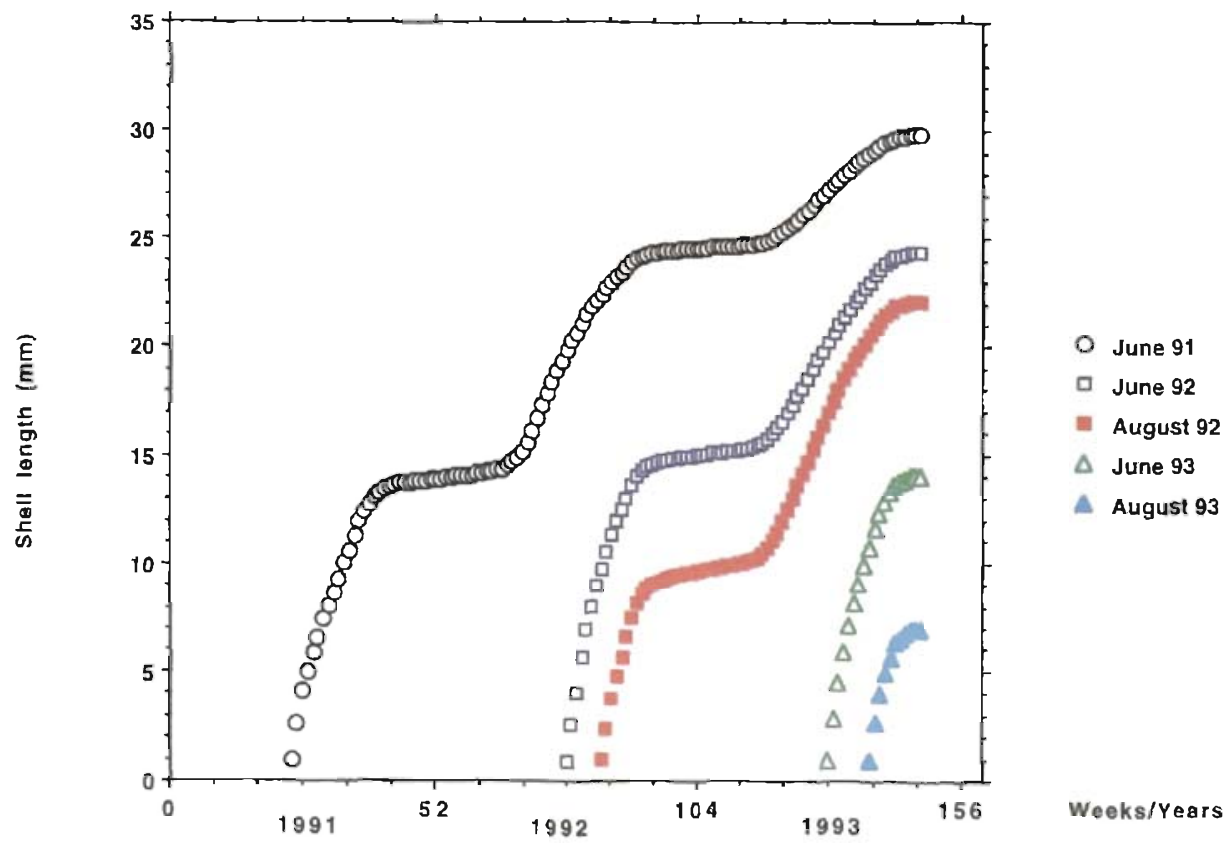

Fig. 2.7. - Shell growth modelling of 5 cohorts of Dreissena polymorpha recorded into the Cattenom cooling circuits from 1991 to 1993.

The two species may be distinguished with the aid of the table 2.3 and photo 2.11.

\section{Biology and reproduction}

The clam Corbicula fluminea is a free-living species found crawling around in the top layer of the river substrate, which in the Moselle is gravel and small pebbles on a clay base (Bachmann et al., 1995). Locomotion is accomplished by means of an extrusible foot (Photo 2.12). According to Morton (1983) a part of the population is hermaphrodite (30\% hermaphrodite; $40 \%$ female; $30 \%$ male). The percentage differs with the flow rate of the river. At higher currents, more females should occur. Reproduction can start at a length of between 6 and $13 \mathrm{~mm}$ (Mattice, 1983; Dubois, 1995). Depending on water temperatures, two to three peaks in reproductive activity can occur annually. The eggs are fertilized in the female and brooded on the two inner gills, till the larvae attain a length of about $220 \mu \mathrm{m}$. The non-planktonic larvae are then released and settle nearby. Up to a length of $14 \mathrm{~mm}$, they are capable of active transportation by water currents, by producing slime threads, and simultaneously opening the shells widely (Prezant \& Chalermwat, 1984). Often, there is largescale migration which results in distinct populations of clams all of 
Table 2.3. - Distinction of the two species of Corbicula by the shell shape and biological features.

\section{Species}

C. fluminalis

C. fluminea

\section{Criteria}

Reference

Shell triangular, pointed with a.Zadhin 1965 (in Dubois 1995)i rounded base, thicker than in C. Morton 1979; 1986

fluminea. Concentric ridges!

thinner and less spaced than in

$C$. fluminea. Maximum length 25

$\mathrm{mm}$. Separate sexes, larvae probably incubated on the gills.I

Life span > 10 years.

Shell an oval triangle. Concentric/Zadhin 1965 (in Dubois 1995), ridges widely spaced. Maximum।Morton 1979; 1986 Dubois 1995i length > $30 \mathrm{~mm}$. Hermaphrodite.'

Larvae incubated on inner gills.:

Life span approx. 3 years. about the same size. The number of larvae per female clam under optimal conditions can be 400 to 900 per day in a population of $20-90 \mathrm{clams} / \mathrm{m}^{2}$ (Aldrige \& McMahon, 1978). Dubois (1995) showed that larval numbers were proportional to the shell length : $\mathrm{Nm}=691{ }^{*} \mathrm{~L}-8568(\mathrm{~L}=$ shell length in $\mathrm{mm}$ ), giving a rate of larval production in the canal-lateral of the Garonne of 571-1372 for populations of 80-360 clams $/ \mathrm{m}^{2}$. Compared to Dreissena with numbers up to $10^{6}$, these numbers seem low, but as Dreissena eggs are fertilized in the water outside the female there will be high initial mortality. The maximum age of Corbicula, depending on the species, is thought to be 3-10 years.

\section{Settlement and growth}

Only the juveniles can form byssus threads, and these may be used temporarily for attachment. However, as this is only a transitory capability the juveniles and the adults can not attach to vertical walls of intake systems. According to Belanger \& Farris (1985) the clam prefers the more coarse aerobic sediment fraction with a particle size of $0.25-0.7 \mathrm{~mm}$. It is a species from subtropical regions and would die in winter if water temperatures stay near to $0^{\circ} \mathrm{C}$ longer than one week (Graney et al., 1980). However, in the muddy substrates in the Dutch river system, combined with the low water temperatures, the clams survive rather well. Presumably, the outlet regions of power stations serve as 'stepping stones' for this species.

Juveniles and adults, up to $14 \mathrm{~mm}$ in length, have been observed to drift in flowing water with the aid of mucous threads (Preznant \& Chalermwat 1984). Live specimens have a variable response to flow depending on the nature of the substrate. On rough sandy bottoms, part of the population drifts at velocities of $10-17 \mathrm{~cm} / \mathrm{s}$ whilst the other part only drifts at $40-45 \mathrm{~cm} / \mathrm{s}$ 


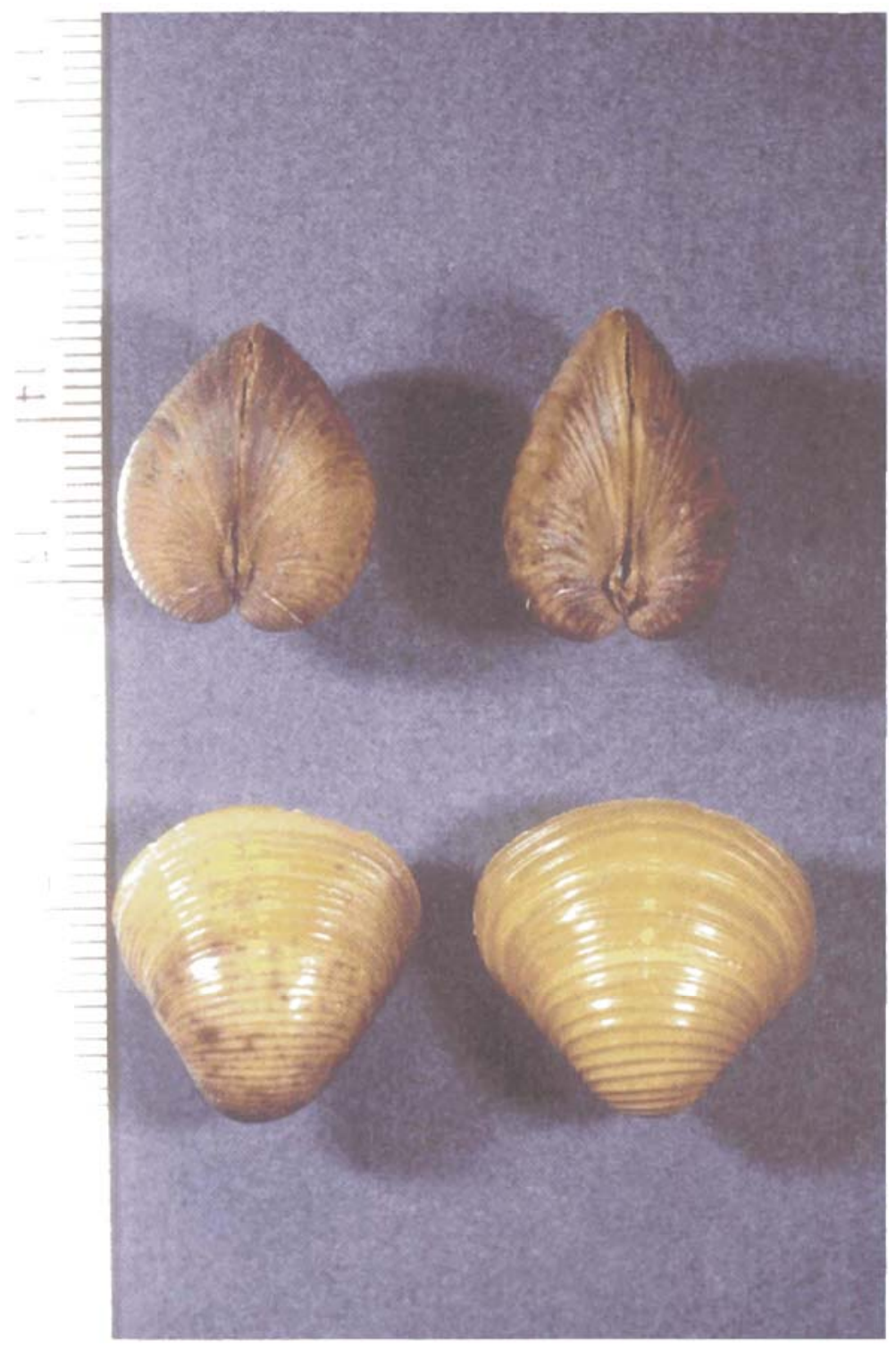

Photo 2.11. - The shell morphology of Corbicula fluminalis (on the left) and Corbicula fluminea (on the right). (Photo V. Bachmann).

(Table 2.4). Dead animals are entrained by water velocities of $15-30 \mathrm{~cm} / \mathrm{s}$ (Dubois, 1995).
The maximum shell size measured in the US is $60 \mathrm{~mm}$; in the Garonne it was $41 \mathrm{~mm}$ in 1995 (Dubois, 1995). 
Table 2.4. - Experimental determination of water velocity required to entrain Corbicula fluminea on rough sandy substrata (Dubois, 1995).

\begin{tabular}{|l|c|c|}
\hline \multicolumn{1}{|c|}{ Categories } & Shell length $(\mathbf{m m})$ & $\begin{array}{c}\text { Water velocity }(\mathbf{c m} / \mathbf{s}) \\
\text { inducing entrainment }\end{array}$ \\
\hline Dead animals & $4.5-15.5$ & $15-30$ \\
\hline Active drifting animals & $5.5-14.5$ & $10-17$ \\
\hline Non drifting animals & $6.5-16.5$ & $40-45$ \\
\hline
\end{tabular}

Optimum water temperatures are about $25^{\circ} \mathrm{C}$ and a growth rate of $1 \mathrm{~mm}$ per week is possible (Welch \& Joy, 1984).

In specimens from the Garonne the growth, which is temperature dependent, is very low when the temperature is below $15^{\circ} \mathrm{C}$ with an optimum very close to $25^{\circ} \mathrm{C}$ (Dubois, 1995) as in the USA. Dubois used one year's measurements to simulate the growth of the shell of the Corbicula fluminea population of a canal of the Garonne Basin. Dubois developed a shell growth model (Fig. 2.8) on three years, based with the thermal regime of 1993-1994. It shows that for the first cohort, the maximum size at the

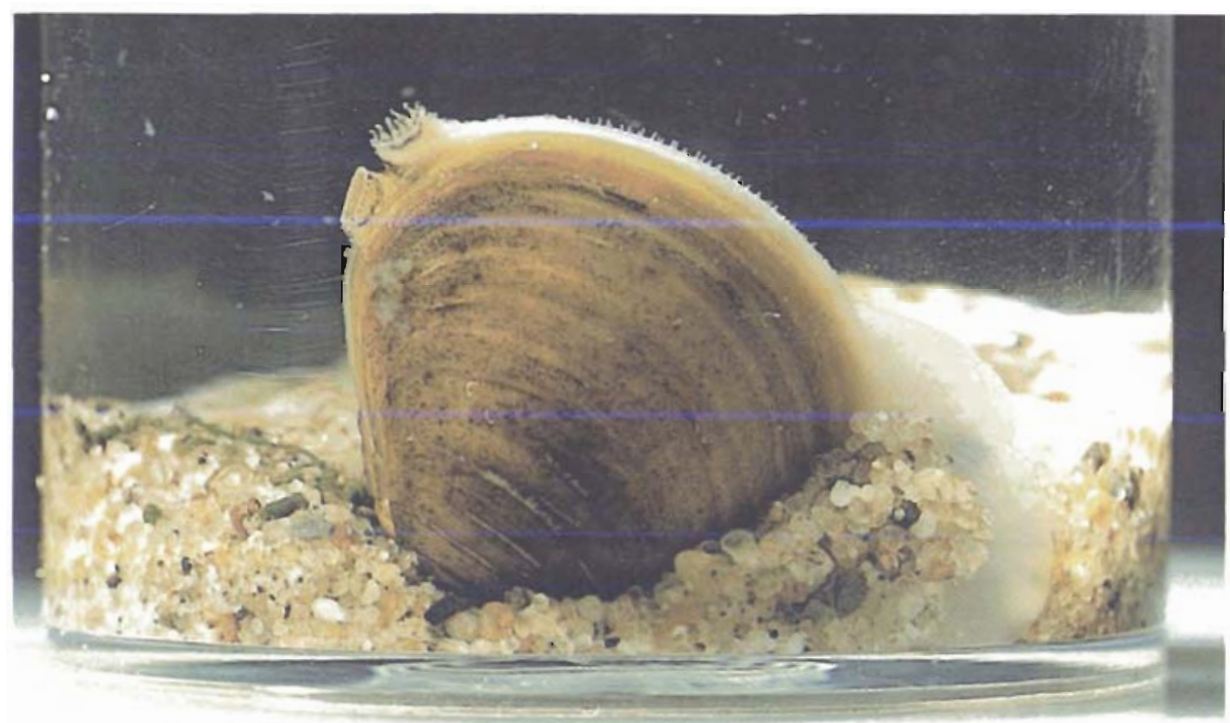

Photo 2.12. - Corbicula fluminea, note the extruded foot used for locomotion but not for byssus thread production. 


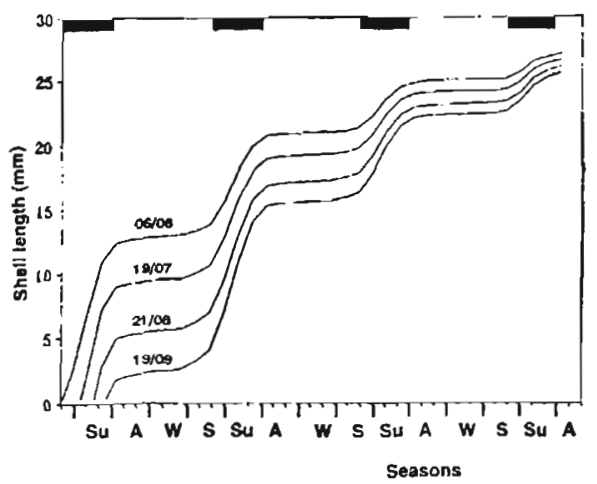

Fig. 2.8. - Shell growth modelling of Corbicula fluminea in the "Canal latéral à la Garonne" for 4 cohorts starting in June, July, August and September. Su : summer, A : autumn, S: spring, $W$ : winter. The black rectangles indicate the reproduction periods. From Dubois (1995 b).

end of the first summer is about 13 $\mathrm{mm}$, and it reaches $21 \mathrm{~mm}$ at the end of the second year.

\section{Amphipods - Corophium curvispinum}

\section{Taxonomy and distribution}

The Order Amphipoda are relatives of the Crabs and Lobsters and belong to the Class Crustacea (photo 13). They are commonly known as Sandhoppers or Scuds. The particular species Corophium curvispinum is a recent invader of the Rhine, originating from Eastern Europe (Behning 1914). Although it has a brackish origin, the var. devium is adapted to fresh water. This species was first recorded in the middle and lower Rhine in Germany and The Netherlands in 1987, since when it has also invaded the northern parts of the Rhine delta
(Van den Brink et al. 1989, 1993). It was earlier recorded since about 1935 (Lincoln, 1979; Harris, 1991) in rivers in the UK. In France the species has been recorded at only two sites in north east rivers: the river Meuse at Chooz (Duvivier \& Vanmaele, 1995) and in the river Moselle on a boulder and cobble bottom (Bachmann et al., 1995).

\section{Biology and reproduction}

C. curvispinum is a a small tubeliving animal: maximum length is 7.0 $\mathrm{mm}$. The tubes are formed from mud particles cemented together with mucus. Because of the density of the individuals on hard substrates and the tube dwelling habit, they form mud banks up to $4 \mathrm{~cm}$ thick (on stones).

Reproduction of Corophium curvispinum occurs in the lower Rhine from April to October when water temperature is in the range of $12{ }^{\circ} \mathrm{C}$ to $20^{\circ} \mathrm{C}$. Ovigerous females (carrying eggs) appear in April and reach a peak in May-June corresponding to $50 \%$ of the population. In July, the overwintering stock of gravid females decreases and reproduction ends in October.

The females carry their eggs in a brood pouch formed by plates on either side of the laterally flattened body. Egg numbers may be as large as 39 per female at the new sites in the lower Rhine, much higher than recorded previously at eastern European sites, and there is a strong positive relation between body length and egg number (Van den Brink et al., 1993, Rajagopal et al., 1999b). 


\section{Growth}

As a filter-feeder, C. curvispinum growth is maximum in rivers rich in plankton or organically polluted. The density of individuals on the stones is positively correlated with current velocity (Van der Velde et al., 1994).
The maximum density recorded from the River Rhine at Tiel in The Netherlands (River Waal) in the years 1986-1994 was $7.5 \times 10^{5}$ per $\mathrm{m}^{2}$ at a depth of 2-3 m (Fig. 2.9). As already stated, density increased with current velocity. As biomass, ash free dry weight (AFDW), at the maximum den-

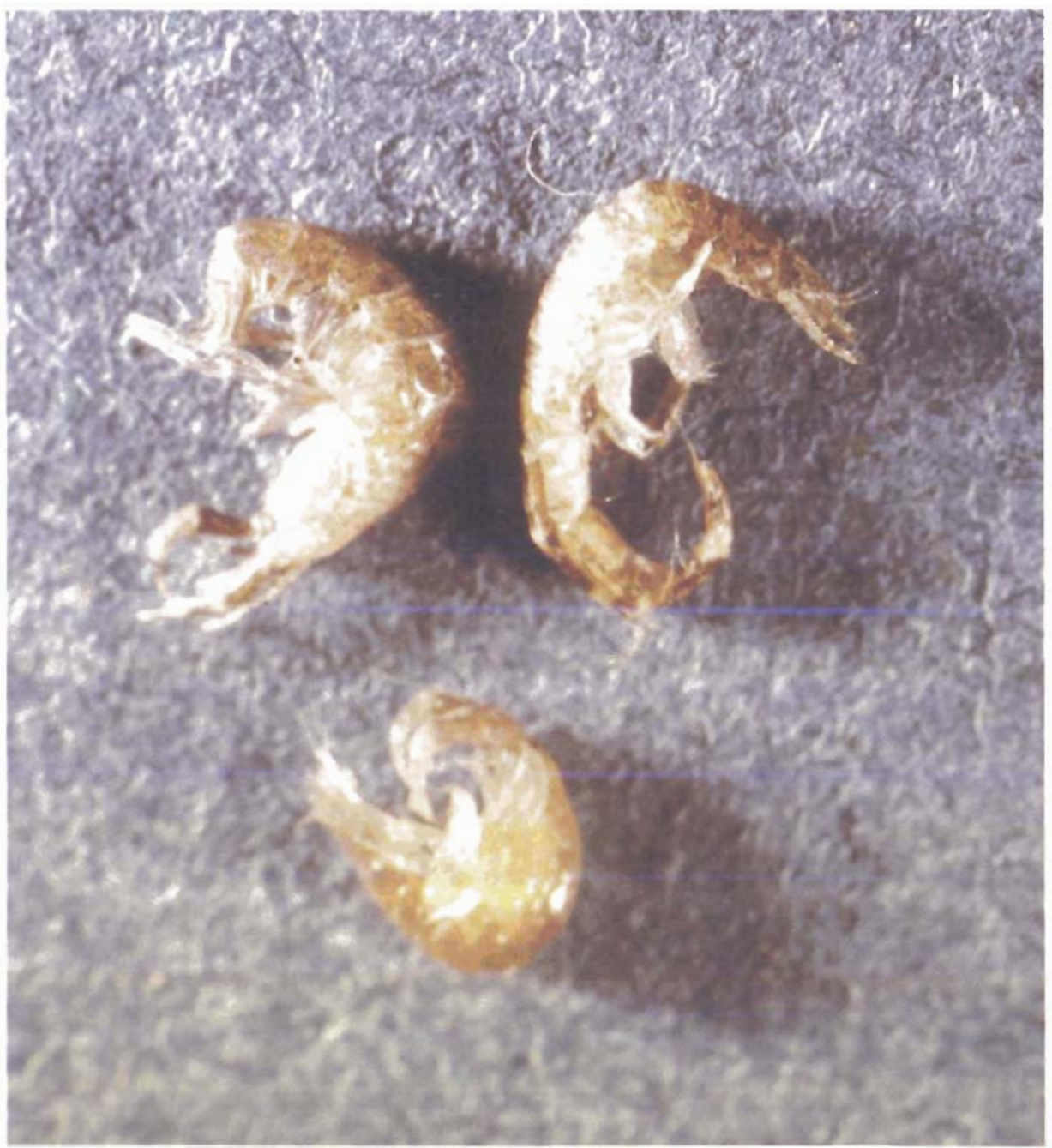

Photo 2.13. - Corophium curvispinum. Photo V. Bachmann. 


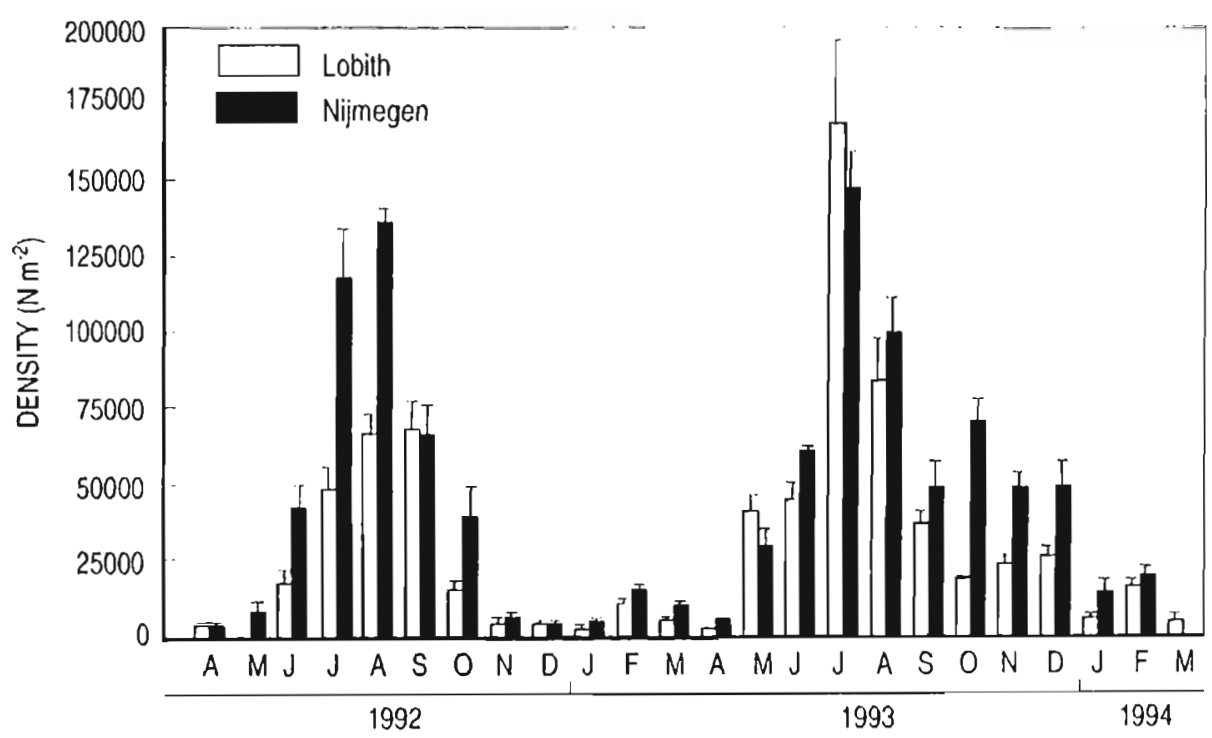

Fig. 2.9. - Density of C. curvispinum on stones in the Rhine (Rajagopal et al., 1999a).

sity was found to be equivalent to $73.0 \mathrm{~g}$ (Van der Velde 1995, pers. comm.). In the Moselle, the maximum density recorded in September 1994 was $97.500 / \mathrm{m}^{2}$ (Bachmann et al., 1995).

This species can accumulate and consolidate a large volume of mud in building its tubes.

\section{Microbial fouling}

Development of microbial slimes will occur on all the heat exchange surfaces. As with all slimes the rate of growth depends on the water quality and the ultimate thickness of the slime coatings will depend on the species, and how much silt is entrapped in the slimes. This problem is also exacerbated by the development of chemical scale within the slimes. Details are given in section 2.4.2.

\section{Chemical fouling}

Scale may develop on heat-exchanger surfaces of direct-cooled power stations when water which has a high natural alkalinity is used as cooling water. However, this problem is not as prevalent as that which occurs in recirculating cooling systems, details will be given in section 2.4.2. 


\subsubsection{Tower assisted cooling}

\section{Introduction}

Circuits equipped with cooling towers are large structures comprising ponds, pipes, culverts, dispersing devices and packing. Compared with once-through cooling circuits, the critical design aspects of the cooling water circuits with regard to the bio-fouling are the greater surface offered to settlement for fouling organisms and the greater extent of low water velocity areas. Such complex circuits have consequently more problems with bio-fouling, they have specific problems with chemical fouling in the form of "scaling".

The cold water pond of such a circuit is especially susceptible to fouling, as flows and temperature are non-limiting. Conduits or water chambers in which the water velocity stays at low level also favour the settlement of bio-fouling and sediment deposits. The shell of the cooling tower and the packing supply extremely large surfaces suitable for the settlement of various species.

The diversity of fouling problems is thus very much greater in such a closed circuit cooling water system than for directly-cooled (open) plant.

\section{Bivalve molluscs}

Significant infestations of Zebra Mussels and Asiatic clams have been reported in cooling tower assisted power stations. Large accumulations of Dreissena polymorpha are found in make-up water pipes and basins at the Cattenom station (Moreteau \& Khalanski, 1994) and Corbicula fluminea is abundant in the Golfech station cold-water pond (Khalanski, 1997 $a, b)$. The data and general comments on these species are given in section 2.4.1.

Unionids. These large bivalves, members of the family Unionidae live in muddy sediments covering the bottom of the water ponds, travelling screens chambers and parts of the cooling circuits where the water velocity is low enough to favour sedimentation. Two genera are commonly found in the circuits: Unio and Anodonta (photo 2) The length of the shell can reach up to $20 \mathrm{~cm}$. Anodonta can be recognised by its thin shell on which teeth are absent.

In muddy sediments, small size bivalves are very common, they generally belong to two genera of the family Sphaeriidae: Sphaerium and Pisidium (photo 2.15).

The shell length does not exceed $12 \mathrm{~mm}$ for Sphaerium and the maximum shell length is usually less than $10 \mathrm{~mm}$ for Pisidium. Sphaeriidae are characterized by a larval development on the gills inside of the pallial cavity.

In cooling circuits, their shells are frequently found in plate heat exchangers in association with muddy deposits.

\section{Bryozoans}

\section{Taxonomy and biology}

The Moss Animalcules are represented in the freshwater fouling com- 

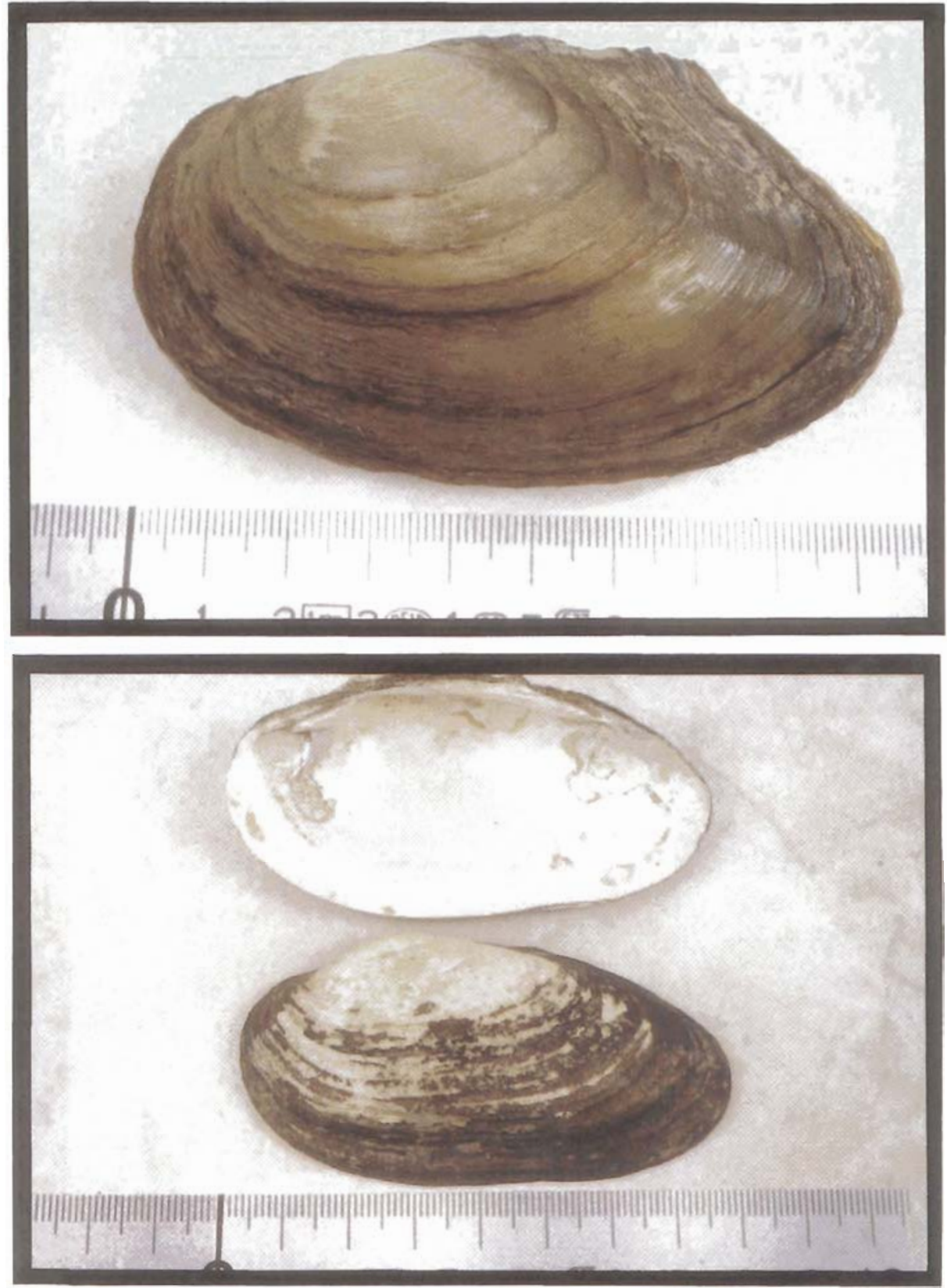

Photo 2.14. - Shells of Anodonta sp. (one valve) from the Seine river and Unio sp. (two valves from the Loire river. Main div. $=1 \mathrm{~cm}$. 
munity by several species: Plumatella fungosa; Plumatella emarginata; Plumatella repens; Fredericella sultana; Paludicella sp.

These are members of the Phylum Ectoprocta, one of the minor phyla of the animal kingdom, and are characterized by their colonial habit. The coIonies are formed of individuals which are about $1-2 \mathrm{~mm}$ in length, and have tentacles surrounding the mouth, the lophophore. The colonies are formed and grow by asexual budding of the animals located within an external chitinous branching sheath. There are both male and female adult members of the colony but reproduction is nor- mally limited to the production of specialised buds with a resistant external cover, known as statoblasts. These are the overwintering and dispersal stage and the means by which the animal recolonises new substrates each spring. Bryozoa feed on planktonic algae and are especially abundant in eutrophic rivers where algal biomass is of the order of several tens of $\mathrm{mg} / \mathrm{l}$ of chlorophyll-a.

Some species produce big colonies; for example, Plumatella fungosa colonies are rounded masses which can reach a diameter of $50 \mathrm{~cm}$. Others are thin rampant or arborescent filaments as Paludicella sp.
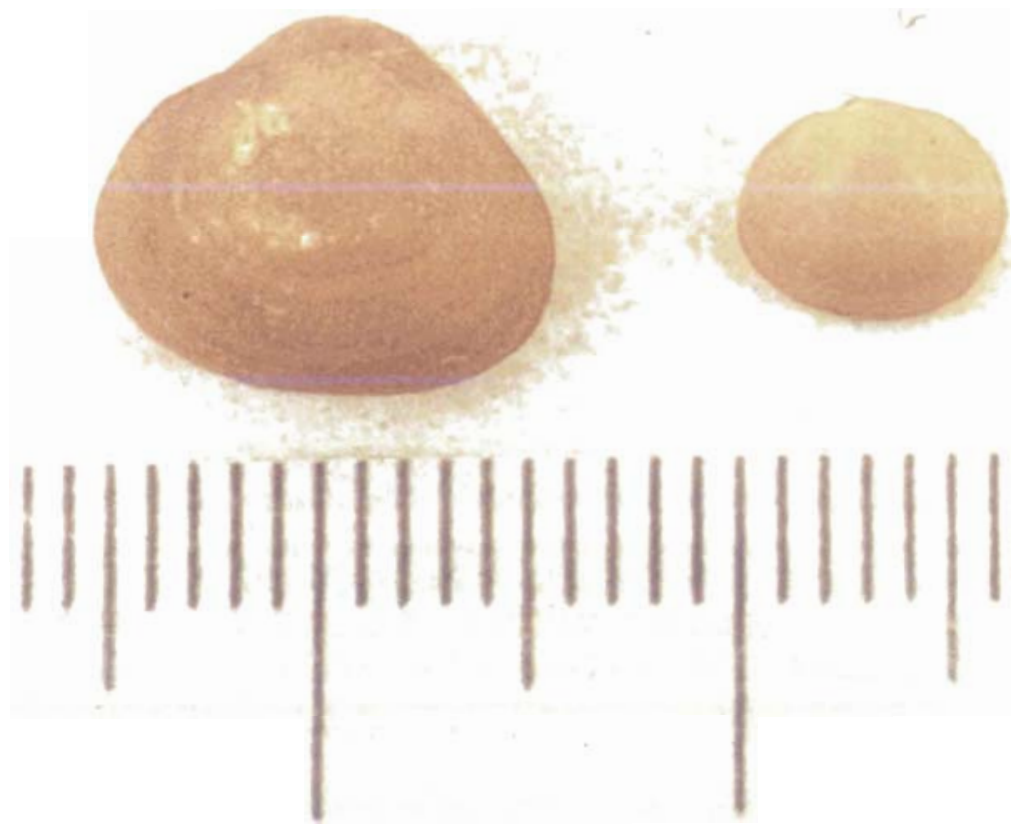

Photo 2.15. - Sphaeriidae bivalves from the Seine river. Main div. $=1 \mathrm{~cm}$. 


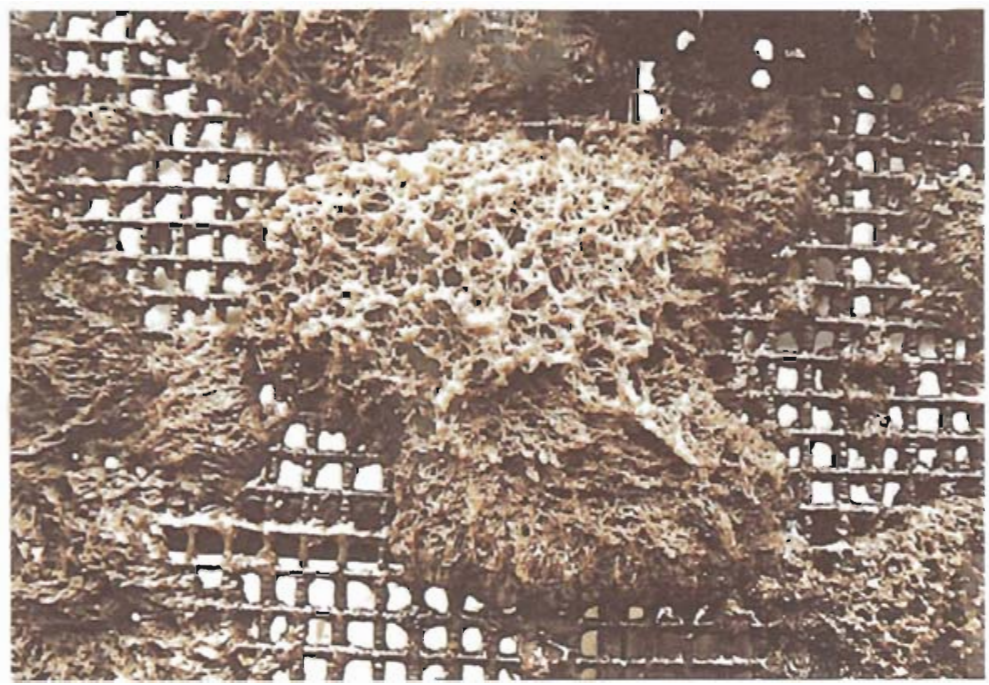

Photo 2.16. - Plumatella colonies on a screen at the exit of a cooling tower pond.

\section{Distribution and growth}

In rivers such as the Trent (UK) where there is a high suspended solids load, colonies are small, no bigger than a few centimetres in height. However, in water which is low in suspended solids and at the appropriate temperature, as in the ponds under cooling towers of power stations on the River Loire, the colonies of $P$. fungosa grow to a diameter of $50 \mathrm{~cm}$ (Photo 2.16). This size difference is related to the efficiency of filter feeding between clear and turbid water. The rate of growth of these large coIonies is between $5-8 \mathrm{~mm} / \mathrm{d}$ and they can interfere with water outflow from the cooling ponds within one year following settlement of the statoblasts (Thome et al., 1989; Aprosi et al., 1986).
Statoblast settlement is optimal at 25-30 ${ }^{\circ} \mathrm{C}$ (Aprosi \& Nepveu de Villemarceau, 1988), but the growth of the colonies by budding is found to be between $15-30^{\circ} \mathrm{C}$. Below $15^{\circ} \mathrm{C}$, growth stops (Duvivier \& Vanmaele, 1995).

Water flow also affects the settlement of statoblasts and has been found to be optimal at $0.2 \mathrm{~m} / \mathrm{s}$. Colonies stop growing at $0.6 \mathrm{~m} / \mathrm{s}$ and are detached by flows of $0.9 \mathrm{~m} / \mathrm{s}$ (Aprosi \& Nepveu de Villemarceau, 1988).

Light has no significant effect on settlement and growth: Bryozoa can settle and grow rapidly in dark pipes but it seems that the optimum for settlement and growth is semi-darkness.

At the Tihange nuclear power station, on the river Meuse in Belgium, the colonies of Plumatella fungosa and Plumatella emarginata are to be 
found growing in a band at levels of between $10-90 \mathrm{~cm}$ above the bottom of the cooling tower ponds (Thome et al., 1989). At this level the flow rate of the pond water is $0.2-0.3 \mathrm{~m} / \mathrm{s}$. Two generations of colonies develop in the ponds during the course of a year:

- The spring generation from April-June, with growth in April/May and die back in June;

- The summer/autumn generation with growth at the end of August to the end of September followed by die back in October.

In the Tihange cold water ponds, the maximum biomass (dry weigth) recorded during the year 1988 was $1,218 \mathrm{~kg}$ for $P$. fungosa and $456 \mathrm{~kg}$ for $P$. emarginata.

\section{Gastropoda}

\section{Taxonomy and distribution}

Gastropods (snails) are very abundant on the muddy bottoms of slow flowing channels, and also in the intake canals and ponds of French nuclear power stations. Four genera are commonly found, Bithynia, Viviparus, Lymnaea and Physa (Photo 2.17).

Small Lymnaea are very abundant in the cooling tower honeycomb packing at Golfech Power Station on the river Garonne and Bithynia are also abundant in the intake structure at power stations on the river Loire. The main problem caused by Bithynia is the clogging of the plate heat exchangers in the auxiliary cooling circuits. The same genus has also caused problems at stations on the river Trent
(UK) where they lodged in the water distribution spray jets of the cooling towers, thus interfering with tower efficiency.

\section{Cyanobacteria (Blue green algae)}

These photosynthesizing microorganisms are found on the inner surfaces of cooling tower shells, and are consequently known as 'shell algae' or 'algues de coque'. They grow as sheets over the inner surface of the towers and interfere with plant operations when the sheets or parts of the sheets fall off the tower shell. This happens when the tower is out of commission during the summer refueling and maintainance period. The algal debris (photo 2.18) collects on the drift eliminators and the top of the plastic honeycomb packing, and end up blocking the grids at the tower ponds exits. This problem is of great concern where a single large tower is used to cool one unit. Much work has been carried out to define the problem (Aprosi \& Nepveu de Villemarceau 1988; Aprosi \& Mossé, 1989; Aprosi \& Costaz, 1989; Aprosi \& Chauvel, 1990; Siclet, 1991).

\section{Taxonomy and distribution}

Shell algae, identified by the Museum National d'Histoire Naturelle (Paris), were collected from six EDF sites: Bugey and Cruas on the Rhône; Chinon, Saint-Laurent and Dampierre on the Loire and Cattenom on the Moselle, (Aprosi \& Mossé, 1989 ; Aprosi \& Costaz, 1989; Siclet, 1991). 


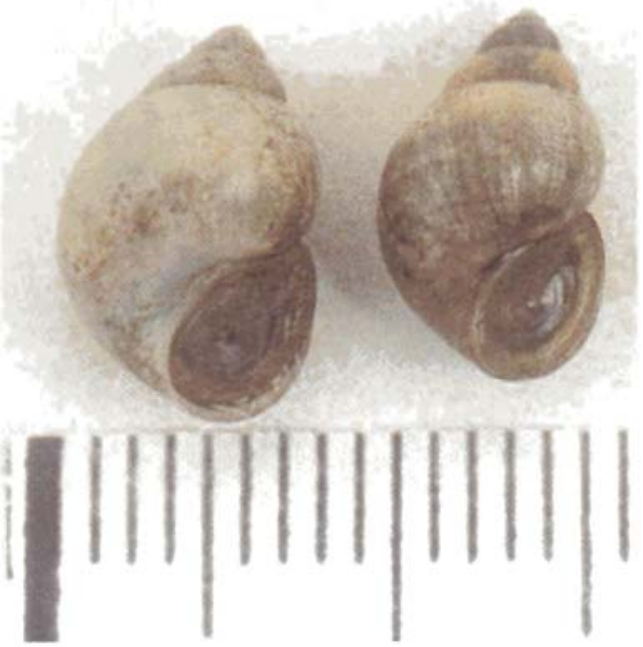

Photo 2.17 A. - Bithynia tentaculata.
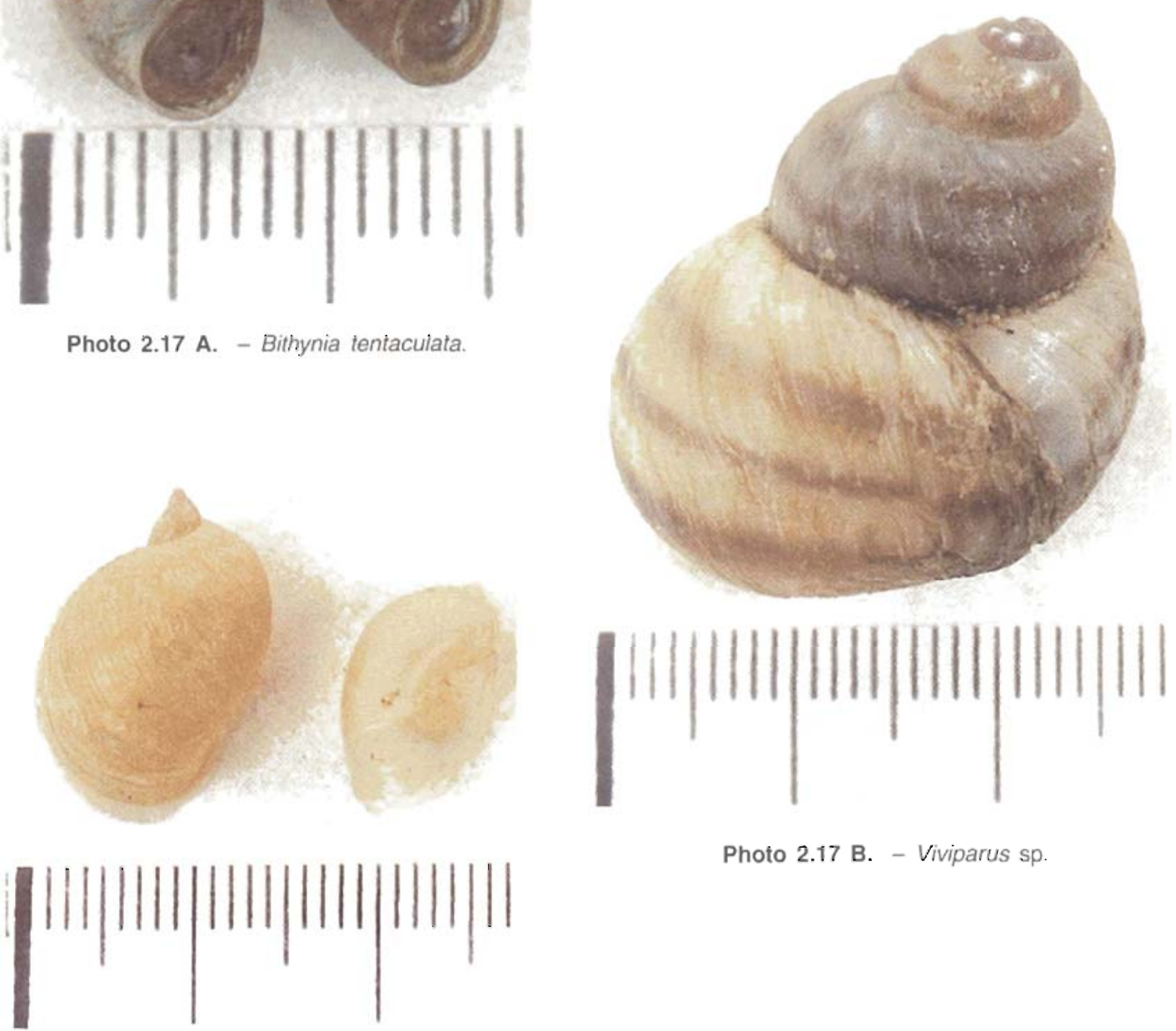

Photo 2.17 B. - Viviparus sp.

Photo 2.17 C. - Radix ovata = Lymnaea ovata.

Photo 2.17. - Gastropods commonly found in cooling circuits of power stations on the rivers Seine, Loire and Garonne (main div. $=1 \mathrm{~cm}$ ). 


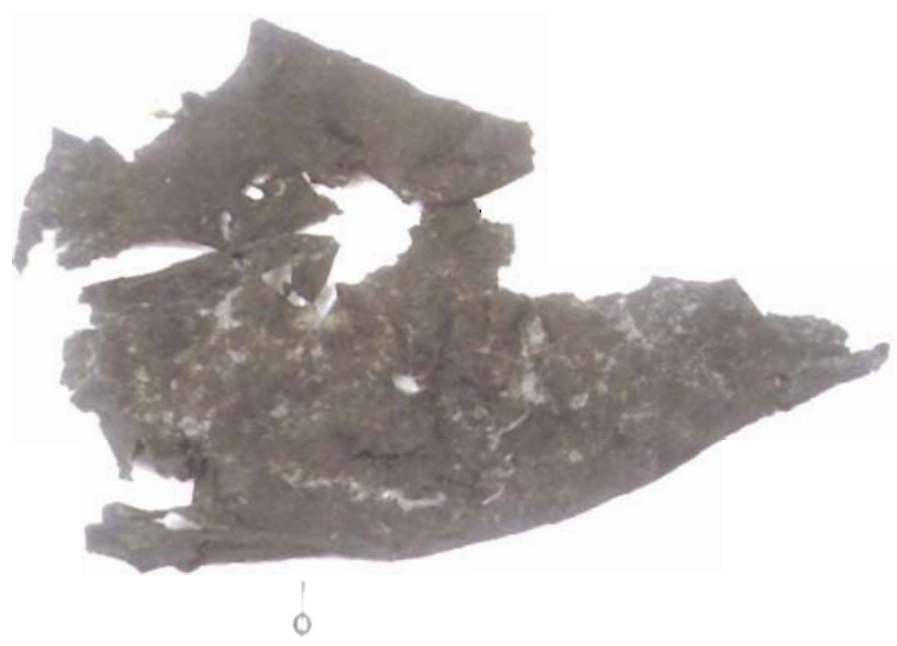

Photo 2.18. - Typical shape of "shell algae". Fragment found at the Saint-Laurent-des-Eaux power station on the river Loire $(25 \mathrm{~cm}$ length).

Three stages are recognised in the colonisation of the concrete shell :

1. Pioneering infestation by small filamentous species (Lyngbya sp., syn. Phormidium).

2. On the primary colonising layer larger species grow (Scytonema multiramosum) with a filament diameter of $15-20 \mu \mathrm{m}$. This second layer completely covers and kills the pioneer species.

3. S. multiramosum still dominates the algal population but additional species of colonial Cyanobacteria (Chroococcus, Nostoc, Gloeothece), some diatoms and green algae make for a more diverse flora.

Shell algae form a more or less continuous layer over the inner surface of the tower. Nutrients, carbon and nitrogen, are supplied by the air current whilst others, phosphorus, potassium, calcium, magnesium etc., come from the water flowing over the surface of the tower.

As Cyanobacteria and algae require light to function, it is evident that light is the main factor limiting growth in towers (Table 2.5).

The quantity of algae formed on the inner surface of a tower was estimated at Cruas (France). This showed that $394 \mathrm{~kg}$ of dry weight algal material was detached from a surface area of $9,650 \mathrm{~m}^{2}$ of the shell, equal to half the total internal surface area. In addition to the dried algae falling off the tower shell the sheet also contained small quantities of the inner surface concrete of the tower. This amounted to $252 \mathrm{~kg}$ from the same 
Table 2.5. - Stratification of algae on the Cruas unit 2 tower with solar light measurements. The green colour is caused by loss of pigments from $S$. multiramosum filaments.

$\left.\begin{array}{|l|c|c|c|}\hline \multicolumn{1}{|c|}{\text { Vertical areas }} & \text { Height }(\mathrm{m}) & \text { Algal layer colour } & \begin{array}{c}\text { Light }(\% \text { incident } \\ \text { sunlight) }\end{array} \\ \hline \begin{array}{l}\text { Top level (neck to } \\ \text { summit) }\end{array} & 120-155 & \text { brown layer } & 25 \% \text { at } 140 \mathrm{~m} \\ \hline \text { Neck level } & 100-120 & \text { brown layer } & \\ \hline \text { Below the neck } & 70-100 & - \text { green layer } & 6 \% \text { at } 90 \mathrm{~m} \\ \hline \text { lower level } & 70 & \text { no algae } & 3 \% \text { at } 70 \mathrm{~m}\end{array}\right]$

detached surface area. The total annual dry weight of shell algae detached from the cooling tower in Cruas unit 2, was thus $646 \mathrm{~kg}$ (Aprosi \& Chauvel, 1990; Siclet, 1991).

The distribution of the detached algae was estimated to be:

$-18 \%(100 \mathrm{~kg})$ is entrained outside the tower by the air current,

- $82 \%(530 \mathrm{~kg})$ fall on the drift eliminators and pass through the packing to go to the cold water pond $(57 \%$ or $371 \mathrm{~kg})$ or stay into the packing $(25 \%$ or $159 \mathrm{~kg})$.

The algal sheets staying in the packing are presumably more or less rapidly decomposed by bacteria but they also agglomerate suspended matters and can form organo-mineral plugs clogging the canals as observed in Cruas power station.

The second nuisance is the risk of clogging grids located in the cold water basin where water goes back to the condenser. However, shell algae contribution to the matters removed from the grids at the Cruas power station is very low compared to Zebra mussel shells.
This loss of concrete could pose a threat to the engineering integrity of the tower, so the weight data were recalculated as a thickness measurement, showing the loss to the surface was $20 \mathrm{~mm}$ per annum. Over a 40 year life this corresponds to an average loss of $2 \mathrm{~mm}$ with local maxima of $3 \mathrm{~mm}$ (Siclet, 1991). This does not pose a serious risk for the lifetime of the tower.

\section{Filamentous green algae}

\section{Taxonomy and biology}

The green alga Cladophora glomerata, belongs to the Thallophyta, Division Chlorophyceae, Order Siphonocladiales. These algae have a branched thallus, in which each branch consists of several multinucleate cells or coenocytes. The individual branches are called filaments. It is present in all rivers, especially those receiving sewage effluent. This alga is well known as 'Blanket Weed' in garden ponds. In power stations, it may cause reductions in efficiency by interfering with the flow of water over the packing in cooling towers. According to Sladeckova (1969), a wide variety of other algal species 
and genera are found fouling freshwater cooling systems, but these systems were of old design with wooden water distribution troughs.

\section{Reproduction and growth}

The alga reproduces both sexually and asexually. Asexual production of zoospores occurs throughout the year whilst gamete production is only found in spring.

Growth takes place at the free ends of the branches, by an apical segment and the filaments may grow to several metres in length. In power stations, they grow on the support legs of cooling towers, on packing exposed below the base of the tower shell (especially when the pack is of wooden slats) and on the walls of the open channels which distribute the warmed cooling water to the cooling tower spray jets and which return the water to the pump suction docks. The filaments may impair water distribution at the outer regions of the pack, causing an insufficient reduction of return water temperature and a consequent lowering of in thermal efficiency.

Monitoring for the presence of growth of green algae can be done by eye or by settlement plates of glass or other suitable material placed in the cooling circuit. Serious problems have been reported only where the packing in the tower is exposed below the base of the tower shell, when the filaments grow to a length of several metres and interfere with the water flow on the packing (Whitehouse \& Blank, 1985). In France, Cladophora are found growing on the walls of the tower ponds at sta- tions on the rivers Loire, Rhône and Garonne.

\section{Microbial Slimes}

Development of layers of slime form as a result of the colonization of surfaces by bacteria of the genera Pseudomonas, Flavobacterium and Bacillus. These bacteria are found on all surfaces throughout the cooling water system, but have most effect on the heat exchange surfaces of the condensers and auxiliary heat exchangers. They are also found on the surface of the plastic fill which is now standard in cooling towers. The conversion of the surface of the plastic sheets from the hydrophobic to the hydrophilic condition, known (to the engineers) as conditioning, is a direct function of the colonization of the surfaces by slime forming bacteria of the Pseudomonas group (Puckorius, 1997). This is only a problem in cooling towers if the slime acts as a base into which either scale or silt or both become entrapped. However, this expression of the slime problem is serious only if the deposits become so thick that the weight of the pack approaches or exceeds the load-bearing capacity of the pack support structure.

Details of the development of slimes has been described by Characklis (1981), who has shown that their growth follows standard bacterial kinetics and is thus dependent on temperature, nutrition and in this case, the surface area available for colonization. Growth also depends on 
the flow of the circulating water relative to the surface which is being colonized. In cooling towers, the flow is below the rate at which shear stress would operate to cause biofilm detachment (Characklis \& Cooksey, 1983), whereas in condensers, it is feasible to have flow rates which maintain the film at a minimum thickness. Growth usually follows the typical sinusoidal curve, showing a lag phase, when colonization is taking place, followed by accelerated growth up to a stationary phase, when diffusion of oxygen and nutrients are limited by the thickness of the biofilm. The rate of colonization is influenced by the choice of materials for the components of the cooling system, for example copper alloys leach copper ions which retard colonization (Chamberlain 1988). Titanium steel condenser tubes have no natural toxicity to bacteria and are therefore colonized very rapidly. The final phase in the development of a bacterial film is dying off, when the thickness of the film may decrease if the reattachment of new cells or the reproductive rates of surface living cells are lower than the death rates of existing cells (Fig. 2.10). A detailed description of microbial fouling and its effects on condensers in power stations is given by EPRI (1993).

Nutrition in cooling tower circuits is proportional to the quantity of makeup water entering the system. The make-up rate is a function of the cycles of concentration used in the system and decreases as the concentration factor (C.F.) increases. Thus, the higher the C.F., the lower the total organic load, and the smaller the bac- terial growth (Whitehouse 1990a; $1990 b)$. Not only is the bacterial nutrient load smaller with a high C.F. but so is the import of all dissolved and suspended materials. The entraining of silt in the slime is also reduced as the C.F. increases.

Other problems are associated with microbial slimes, when thermophilic pathogens such as the bacterium Legionella pneumophila and the protistan amoeba Naegleria fowleri develop in the heat exchangers. Thus $N$. fowleri has been detected in the warm water discharge from power plants in France (Delattre \& Oger, 1981), where it was also present in the discharges from steel works, and in the USA (Tyndal et al., 1989). When a public health risk is identified, either for personnel working on the cooling water circuits or for the public when swimming in designated waters, then specific measures must be taken. These have assessed by Bard

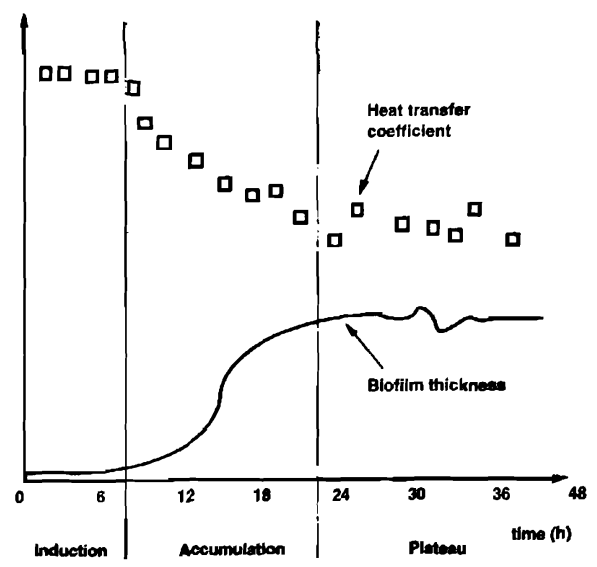

Fig. 2.10. - General growth pattern of slime built-up on surtaces. 
\& Siclet (1995), Cabanes et al. (1997).

\section{Chemical scaling}

Since chemicals, such as carbonates and phosphates are concentrated in the cooling circuit due to evaporation, a dilution with make-up water is required to avoid deposition of scale. The most usual type of scale is calcium carbonate, the input flux of carbonate in large nuclear power stations can vary between 10-60 tonnes per day. Precipitation of carbonate takes place when the solubility product is reached giving rise to scaling of the cooling circuits.

In general, three factors contribute to scaling in cooling circuits at power stations (Whitehouse, 1990a, 1990b; Combaz, 1994):

- heating of the water up to $30^{\circ} \mathrm{C}$ in direct cooling and $45^{\circ} \mathrm{C}$ in tower assisted circuits,

- evaporation of water to effect cooling in passage through the cooling towers, giving rise to concentration of the dissolved salt up to a factor of 1.6 ,

- the loss of free carbon dioxide during passage of water through the towers causing a rise in the $\mathrm{pH}$ which varies with the flow rate and the type of packing. With older timber latted packs, the $\mathrm{pH}$ was generally 7.5-7.8, with plastic film flow pack, this increases to 8.2-8.4 in small towers (250 Mwe) and to $8.5-9.0$ in large towers (900 Mwe or greater).
It is evident that power stations using cooling towers are more susceptible to scaling if the source of make-up water is rich in calcium. Also the materials of construction used in the cooling circuit have an effect on scaling; copper alloys scaling less than stainless steel and PVC (Dedieu et al., 1994). In addition, in experimental test loops (Bolsee et al., 1995), it has been shown that the form of various types of packing influences the rate of scaling (Table 2.6), and also the rate of development and growth of biodeposits (Whitehouse \& Coughlan, 1990; Whitehouse et al., 1987).

These experimental studies show what has been found in practice where massive scaling continued in spite of acid treatment. Thus, at the Golfech power station on the Garonne, 200 tonnes of scale were deposited on 17 months following start-up of the first unitised circuit. Weighings, taken at fortnightly intervals, showed the scaling rate in 1994 was 1 tonne per day (Combaz, 1994). Scaling came from the type of packing, over optimisation of temperature fall giving rise to zones of excessive evaporation, resulting in a heavy well fixed scale. The general view is that towers with plastic packings are more susceptible to scaling than the tubular or plate heat exchangers. Occasionally, excessive scaling has knock on effects; following a break down in the acid treatment, unit 1 at Nogent-sur-Seine power station developed a 10 tonnes per day deposition rate which necessitated the replacement of the packing (Combaz, 1994). 
Table 2.6. - Comparison of the susceptibility of different packing to scaling; from Bolsee et al., 1995.

\begin{tabular}{|c|c|c|c|c|c|}
\hline Material & PVC & PVC & PVC & Polypropylene & PVC \\
\hline $\begin{array}{c}\text { Specific surface } \\
\left(\mathrm{m}^{2} / \mathrm{m}^{3}\right)\end{array}$ & 60 & 180 & 130 & 45 & 120 \\
\hline Thermal efficiency & Satisfactory & High & Very High & Satisfactory & High \\
\hline $\begin{array}{l}\text { Scaling rate at } 40^{\circ} \mathrm{C} \\
\text { (g CaCO} \\
\text { (g } \mathrm{m}^{2} / \text { month) }\end{array}$ & $\begin{array}{l}\text { Non } \\
\text { significant }\end{array}$ & 4000 & 200 & Non significant & 400 \\
\hline
\end{tabular}

Film fill packs deposits are a combination of mineral and organic components. In absence of scaling process, dust and silt transported with air and make-up water contribute to the inorganic deposits. The organic layer on film fill packs is mainly produced by the slime forming bacteria of the Pseudomonas group (Puckorius, 1997). Different cooling water treatments can be made to control the deposits :

- use of biocides, such as chlorine, glutaraldehyde, to eliminate the bacterial development,

- use of dispersants to remove the muddy deposits from the fills.

In closed cooling circuits equipped with cooling towers, severe corrosion problem of copper alloy condensers can be avoided by addition of corrosion inhibitors, mainly aromatic triazoles, to the circulating water. Some research is in progress in the US to reduce the toxicity associated with this type of compounds by using more degradable substances (Rao et al., 1997).

\section{Siltssuspended solids}

Suspended solids are brought into the cooling system with the make-up water. Suspended solids in quantities greater than $100 \mathrm{mg} / \mathrm{L}$ give rise to two problems, accumulation in cooling tower ponds and entrapment in slimes found in condensers and on plastics packing in cooling towers. However, it appears that these problems only become serious when the load of solids in the make-up water is greater than $250 \mathrm{mg} / \mathrm{L}$, equivalent to a mass of 50 $t / d$ for a daily make-up volume of $2 \times 105 \mathrm{~m}^{3}$, the water replacement for a 2,000 MW plant operating at a concentration factor of 1.5. Evidently power stations with cooling towers utilising water with high suspended solids loadings are at risk from loss of system volume and therefore from thermal efficiency losses associated with running the plant at incorrect concentration cycles, caused by lack of observation of the loss of system volume.

Single towers of $1,300 \mathrm{MWe}$ nuclear units have a mass air flow of 
35,000 to $40,000 \mathrm{~m}^{3} / \mathrm{s}$ which contains gnificantly to the mineral and organic dust and various sorts of debris (lea- load in the cooling circuit and interfere ves, feathers, insects, papers etc.). with the mechanical and thermal funcThese airborne imports contribute si- tioning of these circuits. 


\section{Bio-fouling control methods}

The search for the most efficient methods for the control of fouling in fresh and salt water circuits has been going on for a very long time. The first major paper on the subject, with particular reference to power stations, was that of Ritchie (1927). This was followed by the publication of two books, 'Marine Fouling and its Prevention' (Woods Hole 1952) and 'Marine Boring and Fouling Organisms' (Ray 1959). The two works summarize the state of knowledge up to that time, but do not offer useful data upon which to base a marine fouling control protocol at power stations where very large volumes of sea water are continuously passed through the cooling system. However, the value of these two books is in the background information given on the wide variety of compounds investigated in the search for suitable chemicals, and in the details of the life history, colonization and growth rates of the various fouling organisms. Many papers reporting the efficacy of chlorine for the control of mussels have been published since that period (Whitehouse 1975).

It is clear that, to date, the major emphasis for work on fouling control has been in the marine field (White- house et al., 1985). The reasons for this have been well summarized (Mattice 1983), but it is also clear from experience in Europe and the USA in the last half century that freshwater fouling has been seen to prose an equally serious problem, especially as species are transported around the globe and colonize new geographical zones. Good examples of this problem are the Zebra Mussel and the Asiatic Clam. They are also good examples of the need to undertake new research to develop control procedures, as it has been found that previous work on fouling control has been based on american fauna species only and is thus inappropriate. Many studies conducted in Canada and the United States to control the impact of invasion of inland waters by the Zebra mussel at the end of the 80's have given rise to publications of great interest (EPRI 1992; Claudi \& Mackie 1994). Such on going research has been presented yearly since 1991 at the International Zebra Mussel and Aquatic Nuisance Conferences. At the same time, in Europe, continuing effort has been made in the optimization of conventional anti-fouling treatments. New methods have also been investigated. 


\subsection{AN OVERVIEW OF ANTI-FOULING METHODS}

Direct experience of cooling systems and their operational functioning is a prerequisite to the design and monitoring of fouling control in power stations.

Several types of anti-fouling processes have been used on large cooling water circuits, falling into two main categories : physical methods, in which there is no addition of chemical substances to the cooling water, and chemical treatments. Their development status is very variable: some are in widespread or moderate industrial use, others are being tested on site, and many remain for the moment at the level of laboratory research.

It is important to remember that the central focus of this book is biofouling in large cooling water systems (CWS) fed with natural raw waters with flow rates exceeding $1 \mathrm{~m}^{3} / \mathrm{s}$. Effective processes developed for other types of circuits, or to protect ship hulls, are not suitable for industrial applications such as power stations.

In order achieve economically practicable solutions, it is also important to note that methods must be appropriate to each type of fouling (bacterial slime, settled animals or plants) and to the specific design of the cooling circuits.

While there do exist generic solutions applicable to major categories of organisms, optimizing the procedures requires a minimum of biological knowledge. The objective of an eco- nomically and environmentally optimised anti-fouling regime is not total elimination of settled organisms; in most cases, the goal is to control species which settle in the circuits and to prevent their development from becoming excessive. Thus for the period between two scheduled physical cleaning procedures, a chemical treatment must limit fouling of circuits and heat exchangers below the threshold at which plant operation begins to be affected. In many cases, anti-fouling methods on a given site are concerned with only one or two invasive species, for which generic procedures must be adapted in light of their ecological demands which determine the most sensitive parts of the circuit, as well as their periods of larval settlement and their growth rate. This implies acquiring biological knowledge and carrying out long-term biomonitoring on each site so as to follow the evolution in populations and note the appearance of new species as they are introduced (Khalanski, 1997a, b).

Other important elements to be considered are the configuration of the circuits and feedpump operation. These determine the hydraulic regime, most particularly variations in discharge and water velocity, as well as the areas most favorable to settlement and growth of biofouling organisms.

A list of the methods generally used on the cooling circuits of European power stations is given in Table 3.1. As is clear there, many different methods are currently used in European power stations. The phy- 
Table 3.1. - Physical anti-fouling methods and chemical treatments commonly used on cooling circuits of European power stations.

N.B. : Macro-biofouling is that biological fouling of CWS typically caused by: Algae, Sponges, Hydroids, Annelids, Bryozoans, Barnacles, Bivalve shellish and Gastropod molluscs.

\begin{tabular}{|c|c|c|c|c|}
\hline $\begin{array}{l}\text { Processes } \\
\text { and }\end{array}$ & \multicolumn{2}{|c|}{ Methods } & Biofouling Target & $\begin{array}{l}\text { Uses in European } \\
\text { power stations }\end{array}$ \\
\hline \multirow[b]{2}{*}{$\begin{array}{l}\text { Water } \\
\text { filtration }\end{array}$} & $\begin{array}{l}\text { Gross filtration } \\
(>1 \text { to } 10 \mathrm{~cm}):\end{array}$ & $\begin{array}{l}\text { Grids at water } \\
\text { intake generally } \\
\text { equipped with } \\
\text { trash racks. }\end{array}$ & $\begin{array}{l}\text { To remove natural } \\
\text { or artificial drifting } \\
\text { debris at water } \\
\text { intakes. }\end{array}$ & Used everywhere \\
\hline & $\begin{array}{l}\text { Fine mesh } \\
\text { filtration } \\
(1 \text { to } 10 \mathrm{~mm})\end{array}$ & $\begin{array}{l}\text { Rotating screens, } \\
\text { band or drum } \\
\text { filters at water } \\
\text { intakes. Debris } \\
\text { filters to protect } \\
\text { heat exchangers. } \\
\text { Removable grids } \\
\text { with screens. }\end{array}$ & $\begin{array}{l}\text { To remove natural } \\
\text { or artificial drifting } \\
\text { debris at water } \\
\text { intakes. Stops } \\
\text { biological debris } \\
\text { arising from the } \\
\text { fouled walls of the } \\
\text { intake culverts } \\
\text { (shells). }\end{array}$ & Used everywhere \\
\hline \multirow{5}{*}{$\begin{array}{l}\text { Mechanical } \\
\text { cleaning }\end{array}$} & \multirow[t]{2}{*}{ Manual cleaning } & $\begin{array}{l}\text { Dry or underwater } \\
\text { cleaning of pipes } \\
\text { and basins. High- } \\
\text { pressure water } \\
\text { cleaning of } \\
\text { removable screens } \\
\text { and heat } \\
\text { exchangers. }\end{array}$ & $\begin{array}{l}\text { To remove settled } \\
\text { macro-biofouling. } \\
\text { To eliminate } \\
\text { bacterial slime on } \\
\text { condensers or } \\
\text { plate-type heat } \\
\text { exchangers. }\end{array}$ & Used everywhere \\
\hline & & $\begin{array}{l}\text { High-pressure } \\
\text { water cleaning of } \\
\text { rotating screens. }\end{array}$ & $\begin{array}{l}\text { To remove dritting } \\
\text { debris from the } \\
\text { screen. }\end{array}$ & Used everywhere \\
\hline & \multirow{3}{*}{$\begin{array}{l}\text { Automated } \\
\text { cleaning } \\
\text { systems }\end{array}$} & $\begin{array}{l}\text { Continuous } \\
\text { cleaning of } \\
\text { condenser tubes } \\
\text { by sponge balls }\end{array}$ & $\begin{array}{l}\text { To remove } \\
\text { bacterial slime } \\
\text { (and some scale). }\end{array}$ & Widely used \\
\hline & & $\begin{array}{l}\text { Self-cleaning } \\
\text { debris filters }\end{array}$ & $\begin{array}{l}\text { To remove } \\
\text { biological debris } \\
\text { produced by macro-: } \\
\text { biofouling. }\end{array}$ & Widely used \\
\hline & & $\begin{array}{l}\text { Cleaning plate-type } \\
\text { heat exchangers } \\
\text { by vacuum suction } \\
\text { processes. }\end{array}$ & $\begin{array}{l}\text { To remove } \\
\text { biological debris } \\
\text { and mineral } \\
\text { deposits. }\end{array}$ & Some uses \\
\hline \multirow{2}{*}{$\begin{array}{l}\text { Other } \\
\text { physical } \\
\text { methods }\end{array}$} & $\begin{array}{l}\text { High water } \\
\text { velocity }\end{array}$ & $\begin{array}{l}\text { Increasing the } \\
\text { water velocity } \\
\text { above critical } \\
\text { values dependent } \\
\text { on the species to } \\
\text { be eliminated. }\end{array}$ & $\begin{array}{l}\text { To avoid settlement } \\
\text { of macro-biofouling. }\end{array}$ & Used everywhere \\
\hline & Heat & $\begin{array}{l}\text { Increasing the } \\
\text { water temperature } \\
\text { by recirculation for } \\
\text { a few hours } \\
\text { several times a }\end{array}$ & $\begin{array}{l}\text { To avoid settlement } \\
\text { of macro-biofouling } \\
\text { on parts of the } \\
\text { circuits with lower } \\
\text { water velocities. }\end{array}$ & $\begin{array}{l}\text { Some marine and } \\
\text { freshwater power } \\
\text { stations }\end{array}$ \\
\hline
\end{tabular}


Table 3.1. - Contd.

\begin{tabular}{|c|c|c|c|c|}
\hline \multirow[t]{2}{*}{$\begin{array}{c}\text { Processes } \\
\text { and } \\
\text { treatments }\end{array}$} & \multicolumn{2}{|c|}{ Methods } & Biofouling Target & $\begin{array}{l}\text { Uses in European } \\
\text { power stations }\end{array}$ \\
\hline & $\begin{array}{c}\text { Low-toxicity } \\
\text { paints and } \\
\text { coatings }\end{array}$ & $\begin{array}{l}\text { Applied on parts } \\
\text { of the circuits with } \\
\text { lower water } \\
\text { velocities }\end{array}$ & $\begin{array}{l}\text { To avoid } \\
\text { settlement of } \\
\text { macro-biofouling }\end{array}$ & $\begin{array}{l}\text { Some parts of } \\
\text { cooling circuits. } \\
\text { Increasingly used }\end{array}$ \\
\hline \multirow[t]{2}{*}{$\begin{array}{l}\text { Chemical } \\
\text { treatments }\end{array}$} & $\begin{array}{l}\text { Chlorination } \\
\text { with sodium } \\
\text { hypochlorite or }\end{array}$ & $\begin{array}{l}\text { Continuous } \\
\text { treatment at a low } \\
\text { dosage (generally } \\
-1 \mathrm{mg} / \mathrm{L} \text { ). } \\
\text { Possibility of semi- } \\
\text { continuous } \\
\text { injection. }\end{array}$ & $\begin{array}{l}\text { To control marine } \\
\text { macro-biofouling } \\
\text { and bacterial slime. } \\
\text { To eliminate } \\
\text { Bryozoans in } \\
\text { cooling tower } \\
\text { basins }\end{array}$ & $\begin{array}{l}\text { Widely used at } \\
\text { marine power } \\
\text { stations; some use } \\
\text { in cooling towers. }\end{array}$ \\
\hline & $\vdots$ & $\begin{array}{l}\text { Shock chlorination } \\
\text { of cooling tower } \\
\text { basins : } 8 \text { to } 40 \\
\text { mg/L for } 4 \text { to } 6 \\
\text { hours. }\end{array}$ & $\begin{array}{l}\text { To eliminate green } \\
\text { and blue-green } \\
\text { algae. }\end{array}$ & $\begin{array}{l}\text { Some cooling } \\
\text { towers in France \& } \\
\text { Belgium }\end{array}$ \\
\hline
\end{tabular}

Table 3.2. - Methods used in 1996 in EDF power stations on rivers to control biofouling (Khalanski, 1997a).

\begin{tabular}{|c|c|c|c|c|c|c|}
\hline & . & Main & Fouling Orga & nisms & & $\begin{array}{c}\text { New } \\
\text { invasive } \\
\text { species }\end{array}$ \\
\hline $\begin{array}{l}\text { Anti-fouling } \\
\text { methods }\end{array}$ & $\begin{array}{c}\text { Bacterial } \\
\text { slime }\end{array}$ & $\begin{array}{c}\text { Zebra } \\
\text { mussels }\end{array}$ & Bryozoa & $\begin{array}{c}\text { Algae on } \\
\text { cooling } \\
\text { tower walls }\end{array}$ & $\begin{array}{c}\text { Green algae } \\
\text { on cold- } \\
\text { water basins }\end{array}$ & $\begin{array}{c}\text { Corbicula sp } \\
\text { Corophium } \\
\text { Curvispinum }\end{array}$ \\
\hline $\begin{array}{l}\text { Water } \\
\text { filtration }\end{array}$ & 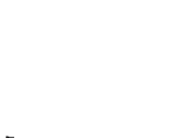 & $\begin{array}{c}\text { Travelling } \\
\text { screens } \\
\text { Debris filters }\end{array}$ & $\begin{array}{l}\text { Small mesh } \\
\text { grids } \\
\text { Travelling } \\
\text { screens }\end{array}$ & $\begin{array}{c}\text { Small mesh } \\
\text { grids } \\
\text { Travelling } \\
\text { screens }\end{array}$ & $\begin{array}{c}\text { Small mesh ! } \\
\text { grids } \\
\text { Travelling } \\
\text { screens }\end{array}$ & $\begin{array}{l}\text { Travelling } \\
\text { screens } \\
\text { Debris filters }\end{array}$ \\
\hline Cleaning & $\begin{array}{l}\text { Continuous } \\
\text { cleaning by } \\
\text { sponge balls }\end{array}$ & $\begin{array}{c}\text { High } \\
\text { pressure } \\
\text { water } \\
\text { Mechanical } \\
\text { cleaning }\end{array}$ & $\begin{array}{c}\text { High } \\
\text { pressure } \\
\text { water } \\
\text { : Mechanical } \\
\text { cleaning }\end{array}$ & $\begin{array}{l}\text { High } \\
\text { pressure } \\
\text { water } \\
\text { Mechanical } \\
\text { cleaning }\end{array}$ & $\begin{array}{c}\text { High } \\
\text { pressure } \\
\text { water } \\
\text { Mechanical } \\
\text { cleaning }\end{array}$ & $\begin{array}{c}\text { High } \\
\text { pressure } \\
\text { water } \\
\text { Mechanical } \\
\text { cleaning }\end{array}$ \\
\hline $\begin{array}{c}\text { Increasing } \\
\text { water } \\
\text { velocity } \\
\text { Shock } \\
\text { chlorination }\end{array}$ & & $\begin{array}{l}\text { Water } \\
\text { velocity } \\
>1 \mathrm{~m} / \mathrm{s}\end{array}$ & $\begin{array}{c}\text { Water } \\
\text { velocity } \\
>0.6 \mathrm{~m} / \mathrm{s}\end{array}$ & ! & $\begin{array}{l}\mathrm{NaOCl} \\
8 \text { to } 40 \mathrm{ppm} \text { to } 6 \text { hours : }\end{array}$ & \\
\hline
\end{tabular}


sical methods comprise water filtration, mechanical cleaning, high water velocity, heat shocks and the use of toxic or non-toxic paints. Among the chemical treatments, chlorination is the most common biocidal approach. This table is in no way exhaustive; the data presented comes essentially from experience acquired by power station operators in France, the United Kingdom, the Netherlands and Italy. For the purposes of illustration, the methods now used in France to control bacterial slime and settled organisms in power stations operated by EDF are summarized in Table 3.2.

New methods have developed from the zebra mussel research projects conducted in North America since the introduction of this species at the end of the 80s. Ontario Hydro and EPRI programs have played a major role in testing these new methods. Some have been tested on-site and have proven to be efficient against this particular invasive species.

Trials have been conducted or are now in progress to test the efficiency of physical methods or selected oxidizing compounds and organic compounds (Table 3.3). These include micro-filtration, non-toxic coatings, UV light, electrolytic currents, cathodic protection, sound energy and organic compounds. In European countries, alternatives to chlorination (chlorine dioxide or ozone) and some organics have been investigated.

All have proven efficient in controlling at least one type of biofouling; however, their field of application, their cost or environmental impacts will li- mit their uses on cooling water systems.

Zebra mussel control programs have shown that some methods such as magnetic fields are not effective or suitable for large cooling water systems. It is also known that bromination and ozonation of sea water generate the same oxidants and byproducts as does chlorination but are more expensive.

Finally, some methods can be useful for very specific applications, such as addition of potassium chloride in fire circuits to eliminate zebra mussels.

Table 3.4 presents a list of potential methods not currently used to control biofouling in large cooling water circuits. These primarily include natural repelling agents, natural biocides, toxins and biological control methods. For these methods, no data is yet available to allow assessment of their efficiency, cost and environmental acceptability on the basis of actual industrial feedback. Some are currently used on completely closed circuits or those with low discharge, or are still in the research phase. Of these, some appear promising and may, in coming years, find applications in large cooling water systems; others will not be applicable to these circuits or will not go beyond the laboratory stage.

It is clear that in this field, we cannot be exhaustive; we shall therefore base our discussion here on recent developments in Canada and the United States as they have been presented in "Zebra Mussel and Aquatic Nuisance International Conferences". 
Table 3.3. - Physical anti-fouling methods and chemical treatments tested on-site on large cooling circuits.

N.B. : Macro-biofouling: Especially Algae. Sponges, Hydroids, Annelids, Bryozoans, Barnacles, Bivalve shellfish and Gastropod molluscs.

(1) KEMA BV listed 13 different organic compounds used as anti-fouling agents in the Netherlands in 1996.

\begin{tabular}{|c|c|c|c|c|}
\hline $\begin{array}{l}\text { Processes and } \\
\text { treatments }\end{array}$ & Methods & Function & $\begin{array}{l}\text { Biofouling } \\
\text { Target }\end{array}$ & $\begin{array}{l}\text { Uses on large } \\
\text { cooling water } \\
\text { circuits }\end{array}$ \\
\hline $\begin{array}{l}\text { Water } \\
\text { filtration }\end{array}$ & $\begin{array}{c}\text { Microfiltration } \\
(<0.1 \mathrm{~mm})\end{array}$ & $\begin{array}{l}\text { Filters to protect } \\
\text { the entire circuit. }\end{array}$ & $\begin{array}{l}\text { Stops plankton } \\
\text { larvae (zebra } \\
\text { mussels, marine } \\
\text { mussels, } \\
\text { barnacles...) } \\
\text { to prevent } \\
\text { settlement on } \\
\text { the walls of the } \\
\text { circuit. }\end{array}$ & $\begin{array}{l}\text { Tested at the } \\
\text { Bergam power } \\
\text { station and in } \\
\text { Canada at an } \\
\text { Ontario Hydro } \\
\text { power station } \\
\text { against Zebra } \\
\text { Mussels. }\end{array}$ \\
\hline & Ultra-Violet light & $\begin{array}{l}\text { Kill macro-fouling } \\
\text { plankton larvae at } \\
\text { the water intake. }\end{array}$ & $\begin{array}{l}\text { To prevent } \\
\text { settlement of } \\
\text { macro-biofouling } \\
\text { on the walls of } \\
\text { the circuit. }\end{array}$ & $\begin{array}{l}\text { Tested in Canada } \\
\text { at an Ontario } \\
\text { Hydro power } \\
\text { station against } \\
\text { Zebra Mussels. }\end{array}$ \\
\hline $\begin{array}{l}\text { Other physical } \\
\text { methods }\end{array}$ & Sound blasts & $\begin{array}{l}\text { Remove macro- } \\
\text { fouling from the } \\
\text { walls of some } \\
\text { parts of the } \\
\text { circuits. }\end{array}$ & $\begin{array}{l}\text { To prevent } \\
\text { development of } \\
\text { macro-biofouling } \\
\text { on the walls of } \\
\text { the circuit. }\end{array}$ & $\begin{array}{l}\text { Tested in the US } \\
\text { on power stations } \\
\text { against Zebra } \\
\text { Mussels. }\end{array}$ \\
\hline & $\begin{array}{l}\text { Non-toxic paints } \\
\text { and coatings }\end{array}$ & $\begin{array}{l}\text { Especially } \\
\text { efficient on the } \\
\text { parts of circuits } \\
\text { where the water } \\
\text { velocity is high } \\
\text { enough to } \\
\text { produce a } \\
\text { synergistic effect. }\end{array}$ & $\begin{array}{l}\text { To reduce } \\
\text { settlement of } \\
\text { macro-biofouling. } \\
\text { To facilitate } \\
\text { cleaning of } \\
\text { fouled walls. }\end{array}$ & $\begin{array}{l}\text { Some parts of } \\
\text { cooling circuits. } \\
\text { Increasingly used } \\
\text { in the US and } \\
\text { Japan. }\end{array}$ \\
\hline $\begin{array}{l}\text { Chemical } \\
\text { treatments }\end{array}$ & & Chlorine dioxide & $\begin{array}{l}\text { To eliminate } \\
\text { macro-biofouling } \\
\text { and bacterial } \\
\text { slime. }\end{array}$ & $\begin{array}{l}\text { Tested on power } \\
\text { stations in Italy } \\
\text { and Spain; used } \\
\text { on large cooling } \\
\text { circuits in Italy } \\
\text { and France. }\end{array}$ \\
\hline & $\begin{array}{l}\text { Oxidizing } \\
\text { compounds }\end{array}$ & $\begin{array}{l}\text { Ozone: } \\
\text { continuous } \\
\text { treatment of } \\
\text { cooling water. }\end{array}$ & $\begin{array}{l}\text { To eliminate } \\
\text { macro-biotouling } \\
\text { and bacterial } \\
\text { slime. }\end{array}$ & $\begin{array}{l}\text { Tested on a } \\
\text { cooling tower } \\
\text { circuit in Belgium. } \\
\text { Applied at RoCa } \\
\text { power station } \\
\text { (tower assisted) in } \\
\text { Rotterdam, } \\
\text { Netherlands. }\end{array}$ \\
\hline
\end{tabular}




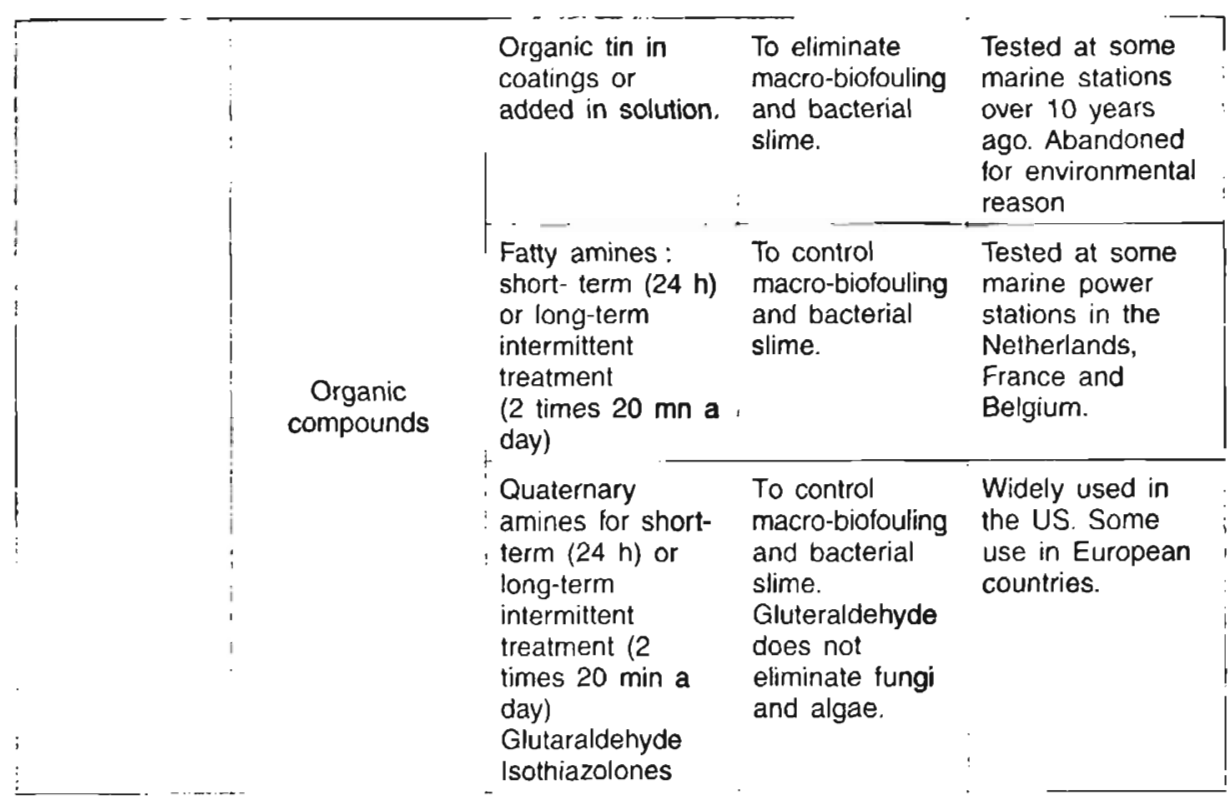

\section{Chemical treatment strategies}

Claudi \& Evans, 1993, defined four basic chemical treatments strategies to eliminate zebra mussels (fig. 3.1), which can be more generally applied to all the macrofouling:

1. End-of-season, consisting in killing the adults and juveniles established in the system at the end of the settlement period of the fouling species. It is only convenient when the operation is not threatened by the excessive development of fouling during the breeding and settling season. Depending on the chemical and the dosage, the required time can be shorter than a day or can cover some weeks.

2. Periodic treatments can be applied if the critical density of fouling is reached in the system before the "end-of-season", it is a variant of the end-of-season treatment.

3. Intermittent treatments are made at frequent dosing (every day or every three days for example) for short period of time (some minutes to one hour). This procedure generally kills or remove the settled fouling organisms on a long-term basis, it must be applied over all the settling season of the target organisms.

4. Continuous dosing at low level of chemical biocide was intially designed to stop the settlement of larvae, but in fact it was observed that this treatment stops or reduces drastically the growth of fouling and kills or removes the biofouling in the long-term more effectively than it is achieved with intermittent dosage.

A fifth category, intermediate between intermittent and continuous, can 
Table 3.4. - Physical anti-fouling methods and chemical treatments not presently used on large cooling water systems or still under investigation (laboratory studies).

Macro-biofouling : Especially Algae, Sponges, Hydroids, Annelids, Bryozoans, Barnacles, Bivalve shellfish and Gastropod molluscs.

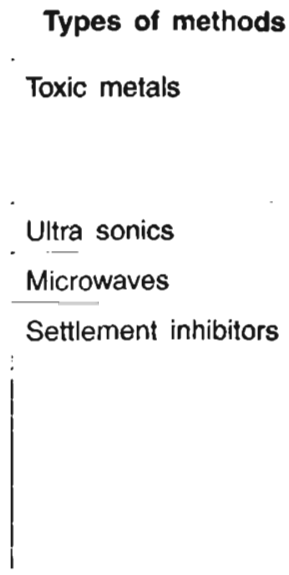

Oxidizing compounds

\section{Methods and Treatments}

Electrolytic generation

of copper and

aluminium ions

\section{Artificial or natural compounds \\ Toxic paints with no toxic releases: \\ Quaternary ammonium grafted on the paint}

Hydrogen peroxide

Paracetic acid

Brominated compounds such as BCDMH (bromochlorodimethyldantoin)

Pathogen agents

Bacterial toxins

Produced by plants or animals

\section{Biofouling Target}

Micro-fouling and macro-fouling.

To prevent settlement of mussel and barnacle larvae.

To eliminate the bacterial film and possibly to prevent settlement of macrobiofouling.

To eliminate bacterial slime and algae: probably efficient against macrobiofouling (known to be involved in some natural antifouling processes, by Echinoderms).

To eliminate bacterial slime and algae: probably efficient against macrobiofouling.

Bacterial slime.

To kill macrobiofouling such as Zebra mussels.

To kill macrobiofouling such as Zebra mussels.

\section{Major current uses}

In small cooling water systems (ships, offshore oil and gas industry)

Research in progress in the US and European countries.

Research in progress

Disinfection of swimming pools and in the food industry.

Disinfection in the food industry.

Research in progress in the US.

Research in progress in the US. 

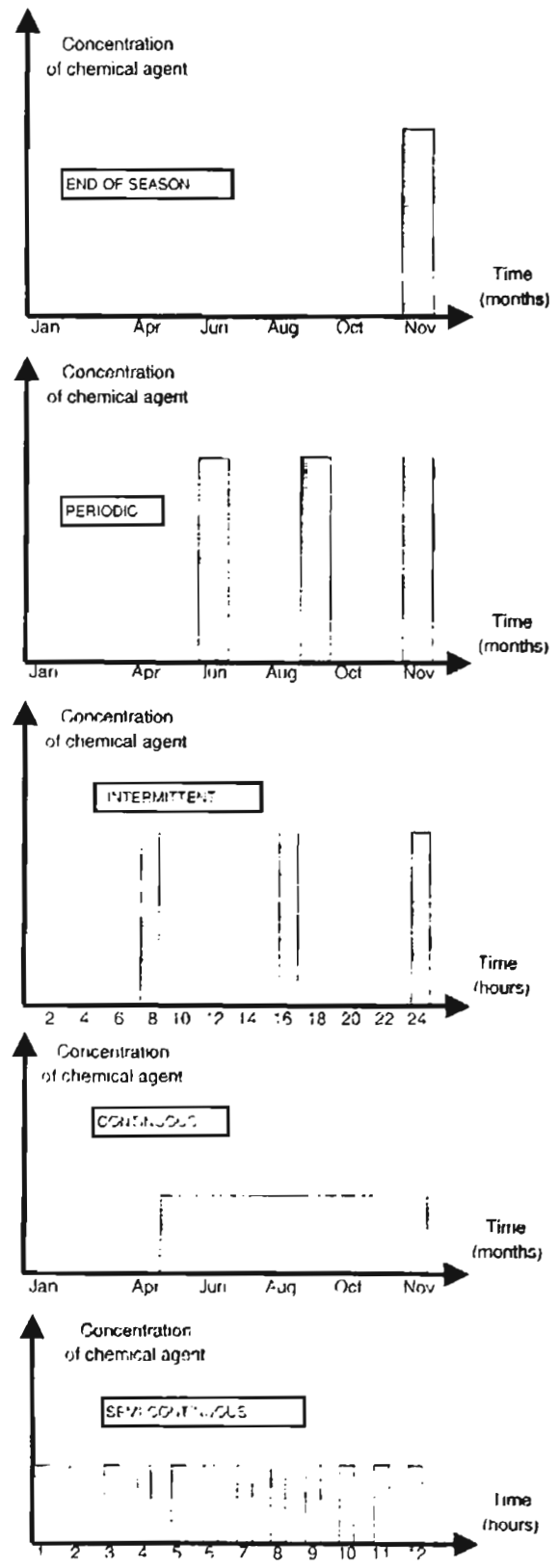

Fig. 3.1. - Chemical treatment strategies. After Claudi \& Mackie, (1994). 
be added; semi-continuous dosing. A low dose of the chemical applied for a short period (15-60 minutes) then stopped for a equally brief period. This long-term, high-frequency treatment, (for instance 30 minutes on / 45 minutes off), can have the same effect as continuous dosing at the same low level.

Regarding efficacy, four selection criteria of chemicals have to be considered :

- the biology of the target biofouling, in particular the location and duration of the settlement period;

- the growth rate of the target species depending mainly of the trophic resource level;

- the mode of action and the toxicity of the chemical (acute or chronic biocidal strategy);

- the maximum fouling density acceptable in the cooling system to be protected (operational tolerance).

For various ecological and economic reasons, continuous or semi-continuous dosing at subacute (chronic) toxicity levels most often is found to be the most pragmatic option.

\section{Cooling towers microfouling}

Film fill packs deposits are a combination of mineral and organic components. In absence of scaling process, dust and silt transported with air and makeup water contribute to the inorganic deposits. The organic layer on film fill packs is mainly produced by the slime forming bacteria of the Pseudomonas group (Puckorius, 1997). Different cooling water treatments can be made to control the deposits :

- use of biocides, such as chlorine, glutaraldehyde, to eliminate the bacterial development,

- use of dispersants to remove the muddy deposits from the fills.

In closed cooling circuits equipped with cooling towers, severe corrosion problem of copper alloy condensers can be avoided by addition of corrosion inhibitors, mainly aromatic triazoles, to the circulating water. Some research is in progress in the US to reduce the toxicity of this type of compounds by using more degradable substances (Rao et al., 1997).

\subsection{WATER FILTRATION}

Water filtration devices of various types are always installed on cooling water systems fed by natural waters. Such devices have specific purposes.

The coarse grid (about $10 \mathrm{~cm}$ spacing) is the first protection; it is located at the opening of the water intake and is frequently equipped with trash racks for removing the largest natural and artificial drifting debris entrained with the water.

The design of this grid and the dimensions of the trash rack system depend on the drifting debris most common in the area in question: kelp at marine sites, aquatic plants on rivers, anthropogenic debris everywhere.

The debris removed is most often accumulated in a special tank and processed as solid wastes. 
Travelling screens represent the second filtration level. These generally consist of a band screen when the flow rate is lower than $10 \mathrm{~m}^{3} / \mathrm{s}$, or drums for higher flow rates. The screen mesh is in the range of $1 \mathrm{~mm}$ to about $1 \mathrm{~cm}$, depending on the type of heat exchangers to be protected: $1 \mathrm{~cm}$ corresponds to circuits with tubular exchangers, 1 to $3 \mathrm{~mm}$ corresponds to plate-type heat exchangers in which the distance between two plates is a few $\mathrm{mm}$.

Such rotating screens are equipped with automated cleaning systems which use pressurized water sprays. The debris removed is sometimes driven with the washing water to the outlet system and mixed with the cooling water; in other instances, it is again accumulated in skips for latter disposal. A great variety of debris is removed by these rotating screens such as seaweed, aquatic plants, mussel mats from the intake canal, shells of organisms settled on the walls of the cooling circuit, etc.

Rotating screens or removable grids with small-mesh screens (1 to $3 \mathrm{~mm}$ ) are installed on the outlet of the cold water basin in cooling towers in order to protect the condenser tubes and the plate exchangers against biological debris coming from the tower : algae, bryozoans, bivalves, gastropods.

Specific debris filters are also sometimes to protect heat exchangers. This type of filter is installed just before the exchanger; the mesh size is generally $1 \mathrm{~mm}$ and the debris is removed by backwashing or intermit- tent maintenance. Equipping platetype heat exchangers with debris filters generally reduces the frequency of cleaning heat exchanges and the investment cost of the filters is thus economically justified.

Microfiltration backwashed systems have recently been developed to remove very small particles (50 to $100 \mu \mathrm{m})$ and theoretically eliminate the plankton larvae of barnacles or mussels from the cooling water. These new filters are claimed to work in high flows, up to $4 \mathrm{~m}^{3} / \mathrm{s}$. Trials have been conducted in Canada by Ontario Hydro to eliminate zebra mussels from an auxiliary circuit of a power station on a lake. In this very pure water, the system succeeded. In practice, this type of system has two major drawbacks in most large European rivers: its low availability in waters heavily loaded with suspended matter, and the limited water flow which can be filtered before clogging occurs. As a result, filtration costs for the high flow rates found in the main cooling system of power stations ( 8 to 240 $\mathrm{m}^{3} / \mathrm{s}$ ) are prohibitive.

\subsection{MAINTENANCE OF FILTRATION SYSTEMS AND CLEANING}

It is difficult to keep a rotating screen fully efficient on a long-term basis; degradation of rubber seals or holes in the screening panels can easily cause entrance of raw water into the circuit, entraining debris such as shells or aquatic plants. One means 
of overcoming this difficulty is to allow in-line maintenance using removable grids, such a system comprises two successive grids, each of which is periodically removed and washed with high-pressure water sprays.

Maintaining trash racks, rotating screens and removable grids in good operating condition requires considerable effort. This induces significant maintenance costs.

Tubular heat exchangers, like condensers in power stations, are frequently cleaned by an on-line cleaning system. The technique consists in recirculation of sponge rubber balls released in the inlet water box of the condenser, then extracted by a strainer at the outlet water box and pumped back to the inlet. This system is convenient for large heat exchangers and commonly used in European power stations supplied by freshwater. Several types of balls covered with specific coatings are used to eliminate more or less hard deposits. With this system, additional chemical treatment is generally not required, but on some sites, such as the Gravelines nuclear power station in France and Hartlepool power station in the UK, continuous water chlorination is combined with sponge rubber balls to control bacterial slime. On-line cleaning systems are costly in terms of investment and operation.

Off-line cleaning can take place at the time of scheduled unit shutdowns for maintenance, inspection, and refueling in nuclear power stations, or during periods of reduced output. Heat exchangers are cleaned with high-pressure water jets or by shooting hard objects into the tubes. Platetype exchangers must be dismounted for cleaning and then remounted, requiring several hours' work on each. Sometimes, they can also be rapidly cleaned by a physical process: vacuum suction or back-flushing which removes any clogging debris and muddy deposits.

Dry manual cleaning of filter chambers, galleries, culverts, pipes and basins, is periodically performed by scraping the macro-biofouling from the walls during maintenance operations. On some sites, in the parts of the circuit which cannot be dried, underwater cleaning is also carried out by divers. The debris covering the bottom of the circuits is removed by suction pumps.

\subsection{WATER VELOCITY}

Water velocity and the potentially complex hydrodynamics of circuit design are important factors in the "fouling potential" of a given cooling system.

Settlement of larvae and the ability of settled organisms to remain on a given surface depend greatly on water velocity. Some species are well adapted to slow-running or even stagnant waters, while others require strong speedy currents.

Water velocity varies considerably in cooling circuits from the water intake structure to the outlet. It is low near filtering devices like traveling screens and in basins, especially coo- 
ling tower basins. It is higher in pipes leading to heat exchangers and in tube heat exchangers. The operating regime of pumps in any given circuit must also be considered as this can cause both variations in flow rate locally and even periods of stagnation.

For organisms which settle on circuit walls, the routine renewal of water in a cooling system is an extremely favourable factor as it provides a source of particulate nourishment and dissolved oxygen. For this reason, when water velocity is not excessive, organisms show optimum growth, generally more rapid than among populations in a natural environment. When the velocity exceeds a critical threshold, larvae no longer settle and adults can no longer feed well; they are even detached from the substrate. In the absence of water circulation, dissolved oxygen becomes the limiting factor and causes death by asphyxia in one to three weeks, depending on the temperature.

These considerations lead to three recommendations :

1. maintain a sufficient water velocity to prevent settlement and growth of macro-biofouling, threshold values are discussed below.

2. avoid a regime with long periods of velocities favourable to the development of biofouling, followed by periods with unfavorable higher velocities, as the larvae can settle and begin growth which will then be temporarily halted. When pumps operate alternately on several circuits, frequent rotation is desirable so as not to leave one circuit at a low velocity for more than one to two consecutive days.

3. avoid temporarily suspending all circulation in a circuit invaded by macro-biofouling for a period of more than three days. During the summer thermal peak, organisms die in about five days. Upon startup of the pumps, they are massively detached and filters at the inlet to heat exchangers are plugged, and often damaged, by the arrival of tons of shells.

\section{Freshwater biofouling and water velocities}

Bryozoans are extremely abundant in the cold water basins of cooling towers on the Loire in France and the Meuse in Belgium. Experimental and field data on the influence of water velocity on the development of bryozoans are summarized in Table 3.5 .

In cooling tower cold basins where the water velocity is less than $0.5 \mathrm{~m} / \mathrm{s}$, gastropod molluscs (Bithynia, Physa, Lymnaea) and Asiatic clams (Corbicula) develop well. Small individuals of these species are also found on the packing.

In pipes and galleries or basins, at maximum water velocities of 0.6-0.7 $\mathrm{m} / \mathrm{s}$, mud deposits favour the development of large Unionid bivalves (Unio, Anodonta) and Asiatic clams.

In natural running waters, Zebra mussels Dreissena polymorpha tolerate a wide water velocity range from $0.05 \mathrm{~cm} / \mathrm{s}$ to $1.0 \mathrm{~m} / \mathrm{s}$ (Leglize \& Ollivier, 1981). Post veligers (<1 mm) are more sensitive to current than adults : 
Table 3.5. - Water velocity and growth of freshwater Bryozoans. Data from Aprosi et al., 1988, Thome et al., 1989.

Species
$\begin{aligned} & \text { Plumatella fungo- Chinon on the } \\ & \text { La Loire }\end{aligned}$

attachment strength is two order of magnitude less than adults (Ackerman et al., 1995). This species is not found at $2 \mathrm{~m} / \mathrm{s}$ although some isolated settled mussels can resist $2 \mathrm{~m} / \mathrm{s}$. At the Mery-sur-Oise drinking water plant near Paris, it was observed that a water velocity of $1.5 \mathrm{~m} / \mathrm{s}$ detaches clusters of mussels. In cooling water circuits of some EDF power stations, zebra mussels are very abundant in all areas where the water velocity is in the range of $10 \mathrm{~cm} / \mathrm{s}$ to $50 \mathrm{~cm} / \mathrm{s}$ but the species is not observed on the parts of the circuit with water velocities exceeding $1 \mathrm{~m} / \mathrm{s}$.

\section{Marine biofouling and water velo- cities}

The effect of water velocity on concrete walls is clearly visible in the data in Table 3.6, collected at the Le Havre plant on the English Channel, operated by EDF.

In a conduit with a large circular section ( 3 to $5 \mathrm{~m}^{2}$ ), colonization of the walls by mussels (Mytilus edulis), barnacles (Balanus crenatus) and hy- droids (Tubularia) is considerably reduced when the mean velocity in the section is in the range of $1.8 \mathrm{~m} / \mathrm{s}$ to $2.2 \mathrm{~m} / \mathrm{s}$; organisms settle in depressions in the walls (anfractuosities, seals). Hydroids trap suspended matter and deposit mud and organic debris. In practice, it appears that settlement and growth of macro-biofouling is halted at $1.8 \mathrm{~m} / \mathrm{s}$ except in specific zones very limited in area. The organic film of bacterial origin, including some hydroids, develops up to $2.2 \mathrm{~m} / \mathrm{s}$ on very rough concrete and is rich in mud. Deposits are completely eliminated at $2.9 \mathrm{~m} / \mathrm{s}$.

In a conduit with a large rectangular section (5 to $11 \mathrm{~m}^{2}$ ), colonization of walls by mussels, barnacles and hydroids is significant at mean velocities of $1.4 \mathrm{~m} / \mathrm{s}$, but seems to be limited at $2.0 \mathrm{~m} / \mathrm{s}$. In galleries with elbows, one wall is less colonized than the other, due to the heterogeneity in velocities.

At the Esbjerg power station (Denmark), the walls of a square section intake conduit $\left(6.25 \mathrm{~m}^{2}\right)$ are totally covered by mussels, the mean water velocity is $1.4 \mathrm{~m} / \mathrm{s}$. 
Table 3.6. - Biofouling development in two intake conduits at Le Havre power station units 1 and 2, as a function of mean water velocity.

\begin{tabular}{|c|c|c|c|c|c|c|}
\hline \multirow[b]{2}{*}{$\begin{array}{l}\text { Ascidians } \\
\text { Ascidiella } \\
\text { aspersa }\end{array}$} & \multirow{2}{*}{$\begin{array}{c}\begin{array}{c}\text { Water } \\
\text { chamber } \\
\text { rotating } \\
\text { screen }\end{array} \\
<0.5 \mathrm{~m} / \mathrm{s} \\
\text { Important } \\
\text { coverage }\end{array}$} & \multicolumn{5}{|c|}{ 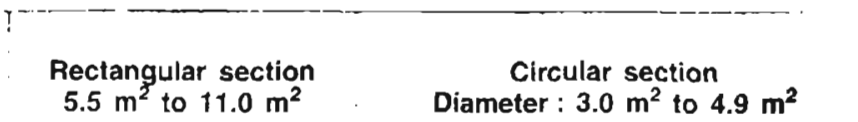 } \\
\hline & & $\begin{array}{l}1.4 \mathrm{~m} / \mathrm{s} \\
\text { Absence }\end{array}$ & $\begin{array}{r}2.0 \mathrm{~m} / \mathrm{s} \\
\text { Absence }\end{array}$ & $\begin{array}{l}1.8 \mathrm{~m} / \mathrm{s} \\
\text { Absence }\end{array}$ & $\begin{array}{l}2.2 \mathrm{~m} / \mathrm{s} \\
\text { Absence }\end{array}$ & $2.9 \mathrm{~m} / \mathrm{s}$ \\
\hline $\begin{array}{l}\text { Mussels } \\
\text { Mytilus } \\
\text { edulis }\end{array}$ & $\begin{array}{l}\text { Important } \\
\text { coverage }\end{array}$ & $\begin{array}{l}\text { Total } \\
\text { coverage of } \\
\text { one wall; } \\
14,400 / \mathrm{m}^{2} \\
\end{array}$ & $\begin{array}{c}\text { Total } \\
\text { coverage of } \\
\text { one wall; } \\
\text { the other is } \\
\text { less } \\
\text { colonized } \\
\text { than at } 1.4 \\
\mathrm{~m} / \mathrm{s}\end{array}$ & $\begin{array}{c}\text { Presence } \\
\text { on seals } \\
\text { only }\end{array}$ & $\begin{array}{l}\text { Presence } \\
\text { on seals } \\
\text { and some } \\
\text { small mats. }\end{array}$ & $\cdot$ \\
\hline $\begin{array}{l}\text { Barnacles } \\
\text { Balanus } \\
\text { improvisus }\end{array}$ & $\begin{array}{l}\text { Important } \\
\text { coverage }\end{array}$ & $\begin{array}{c}\text { Total } \\
\text { coverage of } \\
\text { one wall ; } \\
\text { the other is } \\
\text { less } \\
\text { colonized } \\
\text { (mussels } \\
\text { are settled } \\
\text { on this } \\
\text { surface). }\end{array}$ & $\begin{array}{l}\text { Infrequent } \\
\text { living } \\
\text { barnacles }\end{array}$ & $\begin{array}{l}\text { Presence } \\
\text { on seals } \\
\text { only }\end{array}$ & $\begin{array}{l}\text { Infrequent } \\
\text { living } \\
\text { barnacles }\end{array}$ & $\begin{array}{c}\text { Total } \\
\text { absence of } \\
\text { settled } \\
\text { organisms } \\
\text { and organic } \\
\text { debris }\end{array}$ \\
\hline $\begin{array}{l}\text { Hydroids } \\
\text { Tubularia }\end{array}$ & $\begin{array}{l}\text { Important } \\
\text { coverage }\end{array}$ & $\begin{array}{c}\text { Total } \\
\text { coverage of } \\
\text { one wall } \\
\text { the other is } \\
\text { less } \\
\text { colonized }\end{array}$ & $\begin{array}{l}\text { Some mats } \\
\text { of hydroids } \\
\text { in decompo- } \\
\text { sition }\end{array}$ & $\begin{array}{c}\text { Presence } \\
\text { on seals } \\
\text { only }\end{array}$ & $\begin{array}{c}\text { Some mats } \\
\text { of hydroids } \\
\text { in decompo- } \\
\text { sition }\end{array}$ & \\
\hline $\begin{array}{l}\text { Mud and } \\
\text { organic } \\
\text { debris }\end{array}$ & $\begin{array}{l}\text { Abundant } \\
\text { deposits }\end{array}$ & $\begin{array}{l}\text { Abundant } \\
\text { deposits }\end{array}$ & $\begin{array}{l}\text { Abundant } \\
\text { deposits }\end{array}$ & Very little 0 & rganic deposit & \\
\hline
\end{tabular}

New observations made at the Vado Ligure power station, operated by ENEL in Italy, show that in the intake pipe where the water velocity is near $3.0 \mathrm{~m} / \mathrm{s}$, there are barnacles everywhere, and mussels located mainly on the seals of the pipe, but this "residual fouling" does not pose any problem for the plant operation.
From Japanese experimental data, Kawabe (pers. com.) concluded that the appropriate velocity value must be taken very close to the walls, at $1 \mathrm{~mm}$ from the surface, rather than the mean water velocity. As a consequence, the critical water velocity to avoid macro-fouling growth depends on the size of the conduits. In large 


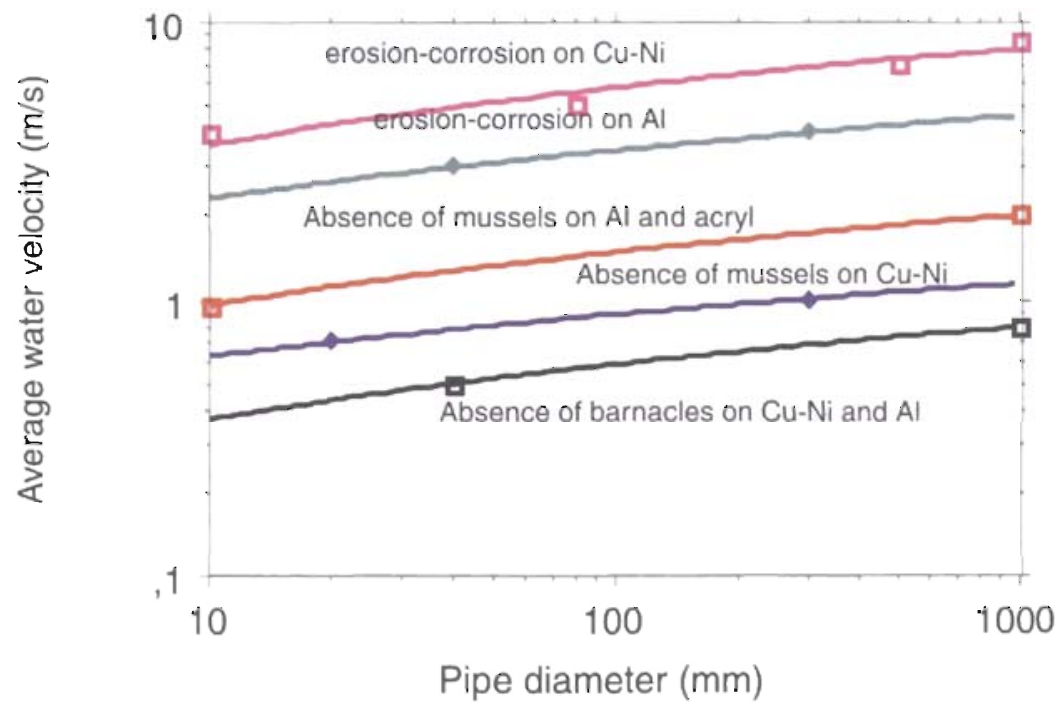

Fig. 3.2. - Average water velocity required to eliminate marine biofouling and erosion-corrosion on metal pipes. Redrawn from Kawabe et al.. 1985.

pipes, the velocity must be higher than in small condenser tubes. A second factor has to be taken into account: the surface roughness which can favour the settlement of larvae. According to this approach, A. Kawabe recommends to maintain in intake conduits a velocity of $1.4 \mathrm{~m} / \mathrm{s}$ at $1 \mathrm{~mm}$ from the walls. In conduits of a $2 \mathrm{~m}$ diameter, the mean water velocity must be $\geq 3.3 \mathrm{~m} / \mathrm{s}$ to prevent the macro-fouling development.

Whatever the discrepancy of these observations and experimental data, it can be concluded that, in pipes maintained without the presence of dead legs or low flow areas, marine mussels generally do not settle in water where the velocity is near $3.0 \mathrm{~m} / \mathrm{s}$, and that macro-biofouling is already reduced at $2.0 \mathrm{~m} / \mathrm{s}$.
The worst case is represented by a square section conduit with water velocities lower than $2.0 \mathrm{~m} / \mathrm{s}$, and rough concrete walls.

On metal walls, Kawabe et al. (1985) tested settlement of mussels and barnacles in circular conduits of three types: a copper-nickel alloy, an aluminum alloy and an acrylic coating. The nomogram obtained from this study (Figure 3.3) gives the mean velocity needed to prevent biofouling and erosion-corrosion of the wall in a pipe with a diameter between $20 \mathrm{~cm}$ and $1 \mathrm{~m}$. On a non-toxic surface (acrylic coating), a velocity of $2 \mathrm{~m} / \mathrm{s}$ must be reached in a large conduit to eliminate mussel settlement totally. This velocity is markedly less than that which determines erosion-corrosion on metal structures $(>4 \mathrm{~m} / \mathrm{s}$ ). 
One important point highlighted by this study is the important influence of the composition of the wall; the efficient velocity in copper or aluminum alloy conduits is considerably lower than that found for the acrylic coating. We can assume that a toxic reaction of the metal ions on the wall makes mussels, and barnacles to an even greater degree, more sensitive to water velocity.

\subsection{HEAT TREATMENT}

Thermal treatment is a highly efficient way to eliminate all macro-biofouling from cooling circuits and is adopted on some European power stations. In the Netherlands, four stations use heating as the only anti-fouling method (Jenner, 1983a).

The cooling water is progressively heated by means of recirculation (see Annex 1) to a maximum temperature of about $40^{\circ} \mathrm{C}$. This maximum temperature is maintained in the circuit for a short time (30 minutes to two hours). All macro-biofouling organisms are killed by the heat shock. It is necessary to optimize this type of treatment in order to kill very small organisms to avoid clogging of exchangers or filters, which requires that one know precisely the settlement periods and growth rate of the major fouling species.

Thermal treatment is not effective against bacterial slime, as the temperature level required to control the bio- film on the heat exchangers is much higher $\left(70\right.$ to $\left.80^{\circ} \mathrm{C}\right)$.

This type of treatment requires a special design of the cooling water system and this needs to be adopted at an early stage of plant construction. Subsequent adaptations are often technically difficult and expensive.

Problems of the expansion and contraction of the concrete walls of the tunnels and conduits as they warm and cool in the cycle of treatment must be solved. Probably even more important are the effect on the turbine and the loss of generation during the treatment period.

\section{Experimental data on freshwater biofouling}

Many experiments have been performed to determine the lethal temperature for the zebra mussel, Dreissena polymorpha, in European countries (Hoestland and Lassablière, 1959; Fejgina, 1959; Kirpichenko et al., 1962; Gillet \& Micha, 1985; Jenner \& Jenssen-Mommen, 1993; Khalanski, 1993; Rajagopal et al., 1997) and in North America (Griffiths, 1992; Iwanyzki \& McCauley, 1993; McMahon et al., 1993). The thermal resistance of the zebra mussel depends on the acclimatation temperature and the biological stage; it would appear that it also depends on mortality criteria (Iwanyzki \& McCauley, 1993).

Table 3.7. shows selected data corresponding to the acclimatation temperature of $25^{\circ} \mathrm{C}$, which is close to 
Table 3.7. - Time to kill $100 \%$ zebra mussels exposed to upper lethal temperatures. All data refer to mussels acclimated to $25^{\circ} \mathrm{C}$.

\begin{tabular}{|c|c|c|}
\hline Upper lethal temperature $\left({ }^{\circ} \mathrm{C}\right)$ & Exposure time (min) & Reference \\
\hline $\begin{array}{l}40 \\
36\end{array}$ & $\begin{array}{l}15 \\
60\end{array}$ & Hoestland \& Lassablière, 1959 \\
\hline $\begin{array}{ll}3 & 7 \\
3 & 7 \\
4 & 0 \\
4 & 0\end{array}$ & $\begin{array}{c}40 \\
20 \\
5 \\
20\end{array}$ & Khalanski, 1993 \\
\hline $\begin{array}{l}34 \\
35 \\
36 \\
37 \\
38 \\
35 \\
36 \\
37 \\
38\end{array}$ & $\begin{array}{c}687 \\
271 \\
202 \\
126 \\
66 \\
525 \\
261 \\
153 \\
78\end{array}$ & $\begin{array}{l}\text { Griffiths } 1990 \\
\text { in Claudi \& Mackie, } 1993\end{array}$ \\
\hline $\begin{array}{l}30 \\
31 \\
32 \\
33 \\
34 \\
35 \\
36\end{array}$ & $\begin{array}{c}5702 \\
3157 \\
2812 \\
1848 \\
253 \\
41 \\
39\end{array}$ & Iwanyzki \& McCauley, 1993 \\
\hline
\end{tabular}

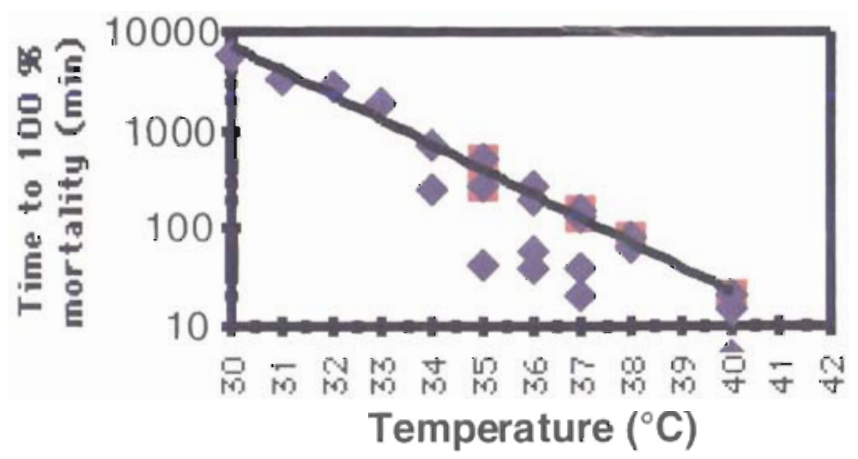

Fig. 3.3. - Time-temperature treatment to kill $100 \%$ of adult zebra mussels acclimated to $25^{\circ} \mathrm{C}$, From experimental data of Table. 
the maximum water temperature in European rivers. A regression line has been fitted on the maximum values (Fig. 3.3), having the formula :

Log Time $(\mathrm{min})=-0.251 *$ Temperature $\left({ }^{\circ} \mathrm{C}\right)+11.38 \quad r^{2}=0.95$.

According to this relationship, at $40^{\circ} \mathrm{C}$ or $39^{\circ} \mathrm{C}$, the exposure time is only 20 to 40 minutes; 1 hour is required at $38^{\circ} \mathrm{C}$ and 2 hours at $37^{\circ} \mathrm{C}$, but more than 11 hours at $34^{\circ} \mathrm{C}$.

In fact, the optimum temperature for this treatment is in the range of 35 to $40^{\circ} \mathrm{C}$ and the exposure time will consequently be in the range of 30 minutes to 10 hours.

In practice, the temperature rise which can be achieved is relatively slow (a $1^{\circ} \mathrm{C}$ to $2{ }^{\circ} \mathrm{C}$ increase per hour), and it generally takes several hours to reach the maximum temperature.

\section{Experimental data on brackish water biofouling}

Laboratory studies have shown that at $37^{\circ} \mathrm{C}$, a $100 \%$ kill of the brackish water mussel Mytilopsis leucophaeata can be achieved by maintaining this temperature for a period of 2 hours. At given target temperatures, $M$. leucophaeata appears to need a longer exposure to ensure $100 \%$ kill than the time needed by M. edulis, (Jenner, 1982) and D. polymorpha (Jenner \& Janssen-Mommen, 1993). The greater environmental stress imposed by brackish waters compared with fresh and marine waters presupposes a higher temperature tolerance in estuarine species (Wright et al., 1983) and this would conform to expectations for an animal originating in the Caribbean (Marelli \& Gray, 1983).

\section{Experimental data on seawater biofouling}

Information on thermal death point for marine organisms can be found in the scientific literature. Marine mussels have been extremely studied and a recent study has been made on the mussels in several parts of the northern hemisphere (Gosling, (ed.), 1992).

In principle, it is best to determine the lethal thermal dose curve for the population of mussels in the area from which the cooling water is to be extracted. Because it is not always possible to do this, an envelope curve can be drawn based on the lethal thermal data for fouling species. Using the equation of the envelope curve:

$\mathrm{T}\left({ }^{\circ} \mathrm{C}\right)=50-2.46$ In $\mathrm{t}\left(\mathrm{T}\right.$ in ${ }^{\circ} \mathrm{C}, \mathrm{t}$ in minutes) [see Fig. 3.4].

It has been found that $40^{\circ} \mathrm{C}$ for a period of one hour will kill $M$. edulis and $M$. californianus, and coincidentally all other macrofouling organisms such as barnacles, hydroids, sea anemones etc. (Jenner, 1983a; Rajagopal et al., 1994).

Where heat has been used as the method for the control of mussels, as at Eems power station in the Netherlands, it has been found that barna- 


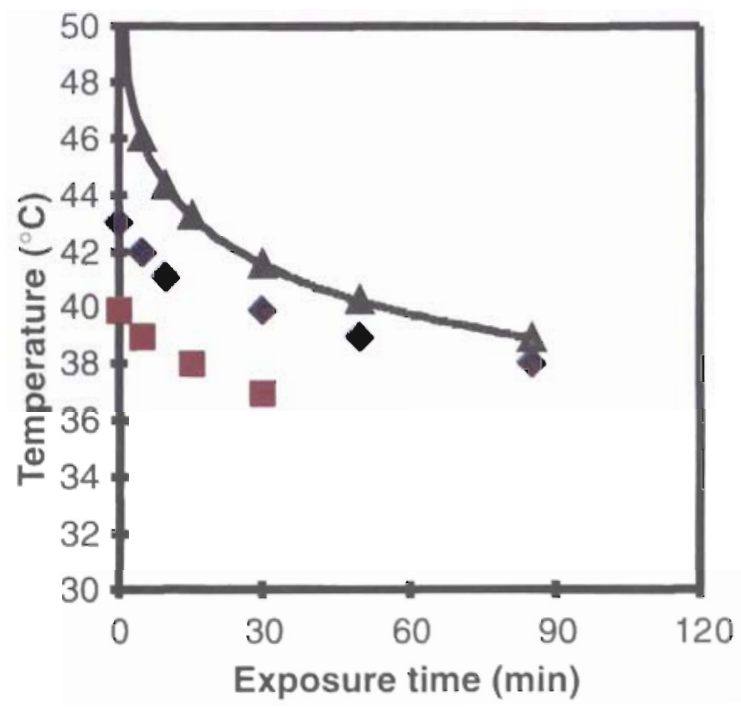

Mytilopsis

Mytilus

A Envelope curve

Fig. 3.4. - Lethal thermal dose curves for marine mussels (Jenner, 1982), brackish water mussels (Rajagopal et al., 1994) and the theoretical curve for thermal data lethal for all fouling species found in the northern hemisphere.

cles, Balanus crenatus, are killed by the application of a temperature of $38^{\circ} \mathrm{C}$ for 30 minutes. The time-temperature mortality curve shows that the mussels are killed in only $30 \mathrm{mi}-$ nutes, but prudence in use of this method of control, due to the narrow band separating survival and mortality, would suggest the use of $60-\mathrm{mi}-$ nute treatments rather than repeated treatments. This approach is consistent with the observation that barnacles have a lower lethal temperature than mussels (Foster, 1969).

\section{Implementation at industrial sites}

In the Netherlands, practical application of thermal treatment at the pre- sent time is restricted to a limited number of locations operating with seawater CWS (Hoogovens, lijmuiden; Eems power station, Delfzijl). In the future it will be used at freshwater-cooled locations as well (Diemen power station; Moerdijk power station). In Dutch marine power stations, blue mussels and barnacles are eliminated by heat treatments 4 to 5 times a year, while treatment can be limited to once or twice a year on cooling circuits using freshwater.

In Italy, thermal treatment is used at La Spezia power station on the Mediterranean coast.

The crucial factor for the determination of treatment frequency is that 
Table 3.8. - Examples of heat treatment at power stations.

\begin{tabular}{|c|c|c|c|}
\hline & & & \\
\hline Power station & Location & $\begin{array}{l}\text { Heat treatment } \\
\text { procedure }\end{array}$ & Reference \\
\hline Eems & $\begin{array}{l}\text { Eems-Dollard estuary } \\
\text { in the Netherlands }\end{array}$ & $\begin{array}{l}3 \text { to } 4 \text { treatments a } \\
\text { year. Maximum } \\
\text { temperature: } 38{ }^{\circ} \mathrm{C} \\
\text { for } 60 \text { min }\end{array}$ & $\begin{array}{l}\text { Whitehouse et al., } \\
1985\end{array}$ \\
\hline La Spezia & $\begin{array}{l}\text { Mediterranean coast } \\
\text { in Italy }\end{array}$ & $\begin{array}{l}20 \text { treatments per } \\
\text { year. Maximum } \\
\text { temperature: } 35^{\circ} \mathrm{C} \\
\text { for } 10 \text { hours }\end{array}$ & \\
\hline SCEC plant & $\begin{array}{l}\text { Pacific coast in the } \\
\text { USA }\end{array}$ & $\begin{array}{l}\text { Maximum } \\
\text { temperature : } 51.7^{\circ} \mathrm{C}\end{array}$ & Graham et al., 1977 \\
\hline $\begin{array}{l}\text { Commonwealth Edi- } \\
\text { son plant }\end{array}$ & $\begin{array}{l}\text { Power stations } \\
\text { cooled by fresh water. }\end{array}$ & $\begin{array}{l}\text { Maximum } \\
\text { temperature : } 37.2^{\circ} \mathrm{C} \\
\text { for } 6 \text { hours. }\end{array}$ & $\begin{array}{l}\text { Claudi \& Mackie, } \\
1994\end{array}$ \\
\hline
\end{tabular}

mussels detached from the walls be small enough to pass through heat exchangers or not be abundant enough to clog the filters.

Typical heat treatments used at power stations are summarized in Table 3.8, and details regarding the Eems and La Spezia power stations are given in Annex 1.

\section{Environmental assessment}

There are advantages to this approach, the greatest being that there is no addition of chemicals, but heat does not function as a method for the control of slime in the condenser and special terms would have to be agreed with the local and national Environment Control Agencies to permit the discharge of water at temperatures well in excess of $30^{\circ} \mathrm{C}$. In practice, if the physical methods adopted are not sufficient to control bacterial slime, or if some critical parts of the circuit cannot be treated by heat, it becomes necessary to complement heat treatment by some use of chemical antifouling products.

\subsection{PAINTS AND COATINGS}

Rather than adding toxic substances into the rapid flow of cooling water circuits, it is possible to treat the surfaces on which biofouling develops so as to prevent settlement of larvae and halt the growth of settled organisms. Paints or complex multi-layer coatings may be applied at different locations in the cooling water systems : intake conduits, screens, pipes, condenser waterboxes and condenser tube plates.

Two major classes of paints and coatings have been developed: those containing one or several toxic substances, and those which contain none and whose action is due rather to their physical surface properties. 
Table 3.9. - Antifouling efficiency of $\mathrm{Cu}_{2} \mathrm{O}$ paints depending on the leaching rate of the copper. Adapted from Kawabe, 1997.

Copper leaching rate

$>20 \mu \mathrm{g} / \mathrm{cm}^{2} /$ day

$20 \mu \mathrm{g} / \mathrm{cm}^{2} /$ day

$15 \mu \mathrm{g} / \mathrm{cm}^{2} /$ day

$10 \mu \mathrm{g} / \mathrm{cm}^{2} /$ day

$<10 \mu \mathrm{g} / \mathrm{cm}^{2} /$ day
These products have mainly been developed for treating boat hulls. For use on cooling water circuits, such paints must be selected in the light of four criteria (Ewans et al., 1992) :

- ability to resist fouling or to provide an "easy-clean" surface,

- absence of toxic releases, or release of toxic substances at an acceptable level,

- long lifetime, steel.

- applicability to concrete and/or

Two other criteria must also be considered: the cost of the product and of product application, and the way in which the coating degrades. To be applicable to cooling water systems, coatings must not detach from the surface at the end of their lifetime, producing fragments which might plug up heat exchangers. The points also have to be applied in the brief opportunities allowed by maintenance programmes and outages.

\subsubsection{Toxic paints and coatings}

Selected toxic substances are introduced in these paints and are progressively released to the surface by

\section{Antifouling action}

No fouling

First weed settlement

Settlement of Hydroids

Settlement of Barnacles

Settlement of all macro-biofouling

a leaching process and by surface erosion. Very low amounts of such substances can generate a sufficient concentration in the immediate surface water layer to have adverse effects on settled organisms. In some new paints, the toxic substance (quaternary ammonium) is fixed on the polymer matrix.

Amongst those surface treatments incorporating toxic organic compounds, thoses paints and coatings containing tributyl tin oxide (TBTO) are very efficient against all types of marine organisms. Because of its extreme toxicity to marine molluscs, TBTO was rapidly abandoned for power stations antifouling treatments in Europe (Whitehouse et al., 1985) and in Japan (Kawabe, 1997). The toxicity of organic tin is now well documented and severe biological effects have been reported for tin concentrations below $1 \mu \mathrm{g} / \mathrm{L}$ (His, 1995). However, some organic biocides, such as 4,5 dichloro-2-n-octyl-4-isothiazolin-3 in Rohm \& Haas paints, are apparently degradable and generate non-toxic metabolites.

Commercially-available toxic coatings generally contain inorganic zinc 
and copper. They are marketed as slow-release, self-polishing and ablative coatings for protection against micro- and macrofouling. In self-polishing paints, the leaching rate of the biocide is constant, whereas it decreases rapidly in traditional paints.

Zinc silicate paint was found to be efficient against zebra mussels, while a copper paint lost its efficacy after 7 months of tests conducted by Ontario Hydro at a power station on Lake Erie (Ewans et al., 1992).

In $1992,77 \%$ of the marine power stations in Japan used toxic antifouling paints. The more commonly used $(39 \%)$ are copper oxide paints $\left(\mathrm{Cu}_{2} \mathrm{O}\right)$ and $8 \%$ are paints containing copper powder. In units painted with $\mathrm{Cu}_{2} \mathrm{O}$ paints, the repainting time interval is generally one to two years $(77 \%)$, but $23 \%$ of the units can withstand a 4-year rhythm (Kawabe, 1997). Tests performed with paints containing $\mathrm{Cu}_{2} \mathrm{O}$ (Yokouchi et al., 1996), have nonetheless demonstrated that they are efficient for only 9 months. The efficacy of such paints depends on the leaching rate of copper ions : the paint is totally ineffective when the rate is less than $10 \mu \mathrm{g} \mathrm{Cu}$ $/ \mathrm{cm}^{2} /$ day (Table 3.9 ). Thus in about 9 months, the leaching rate can decrease from $60 \mu \mathrm{g} \mathrm{Cu} / \mathrm{cm}^{2} /$ day to $10 \mu \mathrm{g} \mathrm{Cu} / \mathrm{cm}^{2} /$ day.

Several types of toxic and non-toxic coatings were tested by Electricité de France on PVC and concrete panels at the Cattenom on the Moselle, from 1991 to 1993. Copper panels were also tested. The reference panels were totally colonized by Hydroids
(Cordylophora caspia) and by zebra. mussels. After four months of tests, the copper panel had no settled organisms and four of the coated panels were less colonized than the controls. A new 12-month series of tests demonstrated the total efficacy of copper against zebra mussels, and the partial efficacy of certain chlorinated vinyl resins containing quaternary ammonium.

The possibility of surface antifouling protection by means of localized production of chlorine at an anode was reported by Lovegrove \& Robinson (1968). Electro-conductive coatings have been developed in Japan for applications in seawater. A current passes through the paint film, generating hypochlorous ions by electrolysis of seawater. The power consumption is very low: a few $w$ per $100 \mathrm{~m}^{2}$. Field tests have proved the antifouling efficiency of such coatings applied with favourable results on the hulls of boats (Usami \& Ueda, 1993), and four marine power station units have experimented with this type of paint. This process generates very small amounts of chlorine, and could be a good solution in environmental terms. However, experiments performed on model canals at the Anan power station showed that cracks appeared in the paint after 6 months and that thereafter biofouling spreads rapidly even on previously treated areas (Yokouchi et al., 1996).

\subsubsection{Non-toxic coatings}

Non-toxic foul-release coatings reduce biofouling by weakening the 
adhesive bond between the organism, film or deposit and the coating. The most promising products available for CWS at this moment are silicone-based paints.

Although silicone-based coatings are fouled by biogrowth, the rate of fouling is lower and it can be wiped off more easily by the cooling water flow.

Silicone-based coatings need generally be applied to a perfectly clean and dry surface, or to clean and almost dry (5\% or less moisture) concrete. For this reason, the technique is more difficult to apply in existing systems, where dry conditions are hard to obtain, than in newly-built CWS. The coatings are usually applied in layers, although experiments with a single layer have also shown good results. The silicones are physically soft and therefore susceptible to impact damage and abrasion. Attempts to toughen silicone paints have always resulted in diminished antifouling performance. The development of a paint with both properties remains a challenge to the paint industry (Leitch 1994). The estimated lifetime of commercially-available silicone coatings is claimed by manufacturers to be 4-5 years, but experimental data generally indicate a shorter period of efficacy.

Results in the U.S. have shown that silicone-based coatings applied to intake pipes accumulate less fouling than those applied to intake walls and other areas exposed to lower flow velocities (EPRI, 1989; Gross, 1991).
In 1990-1991, Ontario Hydro tested different antifouling paints on panels placed at a forebay of the Nanticoke power station on Lake Erie (Ewans et al., 1992). The water velocity was relatively low: 7 to $8 \mathrm{~cm} / \mathrm{s}$. Some silicone paints gave good results : zebra mussel coverage was $\leq 1 \%$ compared to the $100 \%$ coverage on the control, and the settled mussels were only weakly attached to the painted panel. Unfortunately, it was observed that the topcoat of the best silicone paints is easily damaged during handling and preparation of the panels.

Similar findings were obtained by Electricite de France in 1991-1993 in tests at the Cattenom plant on the Moselle, using a silicone epoxy resin which proved efficient against zebra mussels, but which showed poor adherence on a PVC panel.

According to Kawabe (1997), $30 \%$ of Japanese marine power stations used silicone-based paints in 1992. Areas painted with this type of paint are generally retreated every 2 years, but $22 \%$ of the units are repainted on a 4-year rhythm. This does not mean that they are efficient for this long, since tests conducted with these paints on experimental canals in the Anan plant, with a velocity of $20 \mathrm{~cm} / \mathrm{s}$, showed that organisms can settle after 3 to 9 months (Yokouchi et al., 1996).

Practical experience has been acquired in the Netherlands through a number of pilot trials with exposure panels, inlet culverts and heat exchanger inlet boxes at Dow Benelux, Terneuzen, Dodewaard power station 
(freshwater) and Maasvlakte power station. Two commercially-available silicone-based coatings have been tested on exposure panels by KEMA for two seasons in fresh, brackish and sea water. In freshwater, the panels were still clean after two seasons. In brackish water and seawater, fouling developed, although less than on reference (PVC) panels, although the biofouling that had developed was easily removed by hand. The coatings proved to be effective in cooling water intakes, conduits and the inlet chambers of heat exchangers.

At Dow Benelux, experiments with a coated plate in the "KEMA Biofouling Monitor", showed that young stages of mussels settled on the coating, and detached when having reached a length of approximately $1 \mathrm{~mm}$. On the uncoated PVC plates in the same device, mussel spat settled and grew up to $2 \mathrm{~cm}$ within one fouling season.

In a recent study subsidized by the German Federal Environmental Agency, some non-toxic coatings were tested in seawater at four sites on the North Sea and the Baltic coast (Watermann et al., 1997). The marine fouling organisms on the control panels were barnacles, Bryozoa, mussels, annelids, hydroids and ascidians. Nine silicone coatings were selected as being the most representative of "non-stick" coatings and were tested in "static conditions" with water velocities in the range of $0.22 \mathrm{~m} / \mathrm{s}$ to $0.45 \mathrm{~m} / \mathrm{s}$ generated by tidal currents or with a shortterm increase to $2.2-2.7 \mathrm{~m} / \mathrm{s}$ for one hour a month when panels were placed on board a catamaran. Four sili- cone polydimethylsiloxanes (PDMS) were very effective in the prevention of macrofouling over the 6-month period. The four coatings showed no significant variation in surface free energy over the 6-month test period. The adhesion force of adult barnacles Balanus amphitrite was considerably reduced compared with the control (Table 3.10). In this study, some discrepancies appeared between laboratory experiments and field trials: Intersleek and Everclean did not inhibit cyprid settlement in the laboratory whereas they do in the field.

\section{Prospects for antifouling paints in cooling water systems}

At the moment, the most promising paints and coatings are :

- self-polishing paints containing $\mathrm{Cu}_{2} \mathrm{O}$ and possibly some organic biocide with no adverse ecological effects,

- silicone-based "foul-release" coatings, whose efficacy depends to a large extent on the water velocity: they are more effective at high water velocities.

It remains necessary to perform on-site tests with rigorous measurement procedures to verify the conditions of applicability on treated surfaces, the antifouling effects and the lifetime. Only on-site experiments can provide the quantitative data required for an economic estimation, by indicating the reduction in the cost of cleaning processes and of loss of power generation. 
Table 3.10. - Adhesion force of barnacles on different coatings and areas free of macrofouling in \% of the test area after 6 months of trials. Data from Watermann et al. (1997).

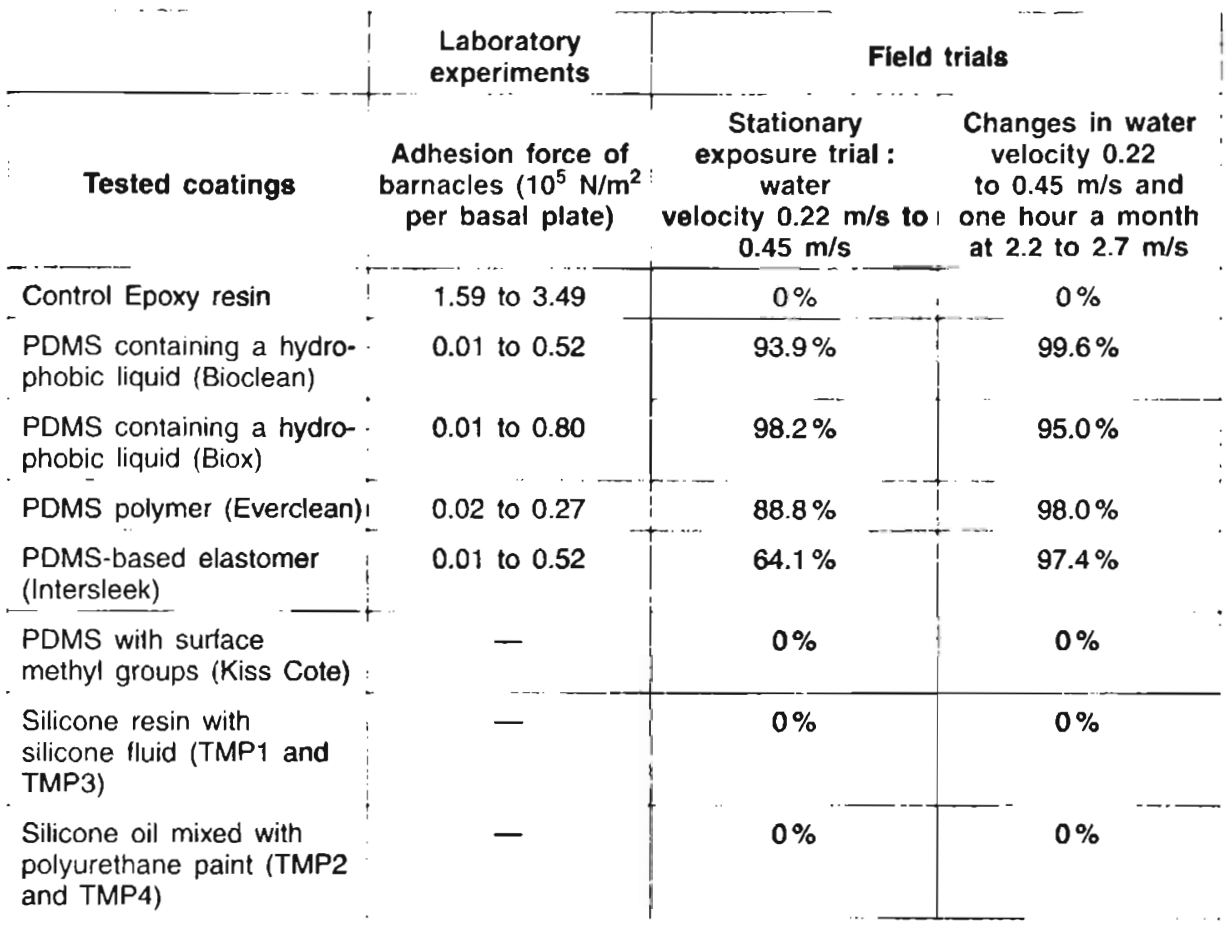

Despite the uncertainties, it is clear that antifouling paints are of particular interest in the control of macro-biofouling and will probably see great development and use by European operators in the future.

Some U.S. utilities operating marine power stations which have problems with barnacles, oysters and mussels developing in intake conduits, have collaborated with EPRI in testing siliconebased foul-release coatings with some success (Tsou 1996, Gross 1996). At a LILCO power station, such a coating was still found to provide excellent macrofouling protection in the fourth year after application. The use of non-toxic coatings is encouraged by the U.S. EPA and generates financial benefits due to savings on cleaning, disposal and fuel costs.

In Denmark at the Esbjerg power station, a marine site with severe mussel fouling, a full-scale experiment with a three-layer silicone coating from a Danish manufacturer was found to be successful during 3 years of operation. Inspection of the culverts during maintenance showed that the top-layer of the coating was still intact; which expects a lifetime of at least 4 years.

In Spain, toxic and non-toxic coatings were applied in 1997 to intake conduits at the Vandellos B nuclear power station, operated by UNESA. 


\subsection{CHEMICAL TREATMENTS WITH OXIDIZING COMPOUNDS}

\subsubsection{Chlorine}

Chlorine was first used in Europe and North America in the early 1900s for the disinfection of drinking water, and resulted in a dramatic decline in typhoid and cholera cases. At the present time, it is largely used as a powerful oxidizing agent for water treatment, such as taste and odour control, disinfection of drinking water and waste water, in the food industry and for biofouling control. Of all the disinfectants, it is certainly the most extensively studied with regard to chemistry, toxicity and ecotoxicity. Due to its well-tried technology, its longterm worldwide industrial uses and its acceptable cost, chlorine remains the most common antifouling treatment to date.

The ideal biocide is highly toxic to one particular organism or group of organisms but has no side effects on 'non-target' organisms. It is not consumed by reactions with materials in the water (i.e. there is no 'demand') and as soon as it enters the environment, it breaks down into non-toxic forms. Chlorine is a long way from this ideal: it is non-specific and reacts with virtually all constituents of natural waters - including man-made pollutants - to yield products having varying degrees of persistence and toxicity. Traditionally, the main environmental concern has been with the acutely toxic but easily measured oxidants, rather than with possible chronic effects of non-longer term oxidants. This situation is changing and the time has now come to consider the complex mixture of halogenated by-products produced by water chlorination.

\subsubsection{Chlorine storage and on-site production}

Chlorination in natural waters is possible in one of three ways : dissolution of chlorine gas, mixture with a sodium hypochlorite solution which, like the gas, may be stored on site, or production of a sodium hypochlorite solution in situ by electrolysis of seawater.

Chlorine gas $\left(\mathrm{Cl}_{2}\right)$, can be kept under pressure in tanks, which presents the advantage of storing large amounts of chlorine in a small volume and of allowing for treatment of water at high flow rates. Chlorine gas is the least expensive of chlorine products. A few accidents during transport or storage have led industry to prefer sodium hypochlorite. Great progress has recently been made, however, in ensuring safe storage of chlorine gas.

Sodium hypochlorite $(\mathrm{NaOCl})$ in concentrated solutions is stored onsite in tanks with no metal walls, to prevent decomposition. In the dark, decay is temperature-dependent. The recommended maximum storage time is one month. Commercially available sodium hypochlorite has an active chlorine concentration of $10 \%$ to $15 \%$. To improve mixing with cooling 


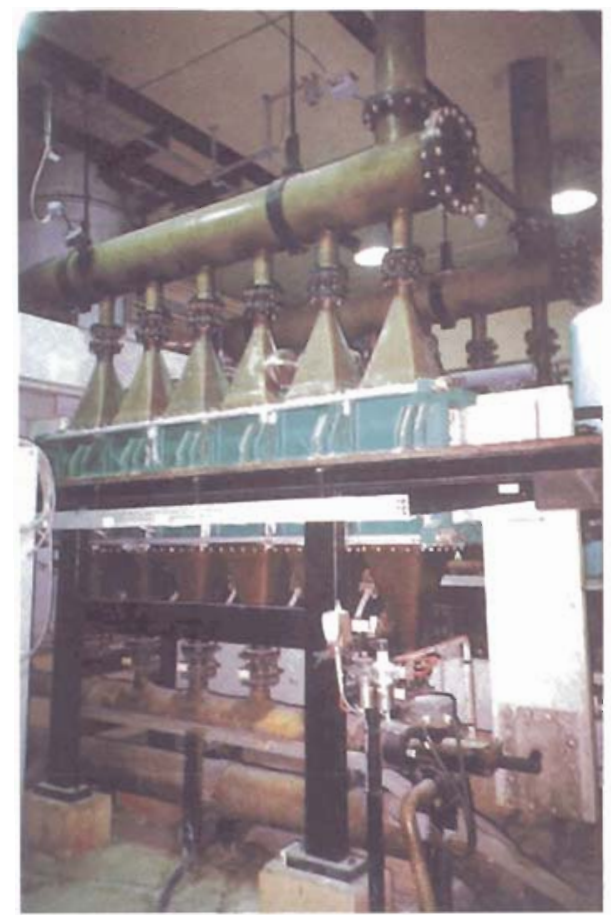

Fig. 3.5. - Electrochlorination cells at the Paluel Nuclear power station, operated by EDF.

water, the concentrated solution can be diluted prior to dosing to about 0.5 $\mathrm{g} / \mathrm{L}$ to $2.0 \mathrm{~g} / \mathrm{L}$.

At marine sites, when large amounts of chlorine are required to treat cooling water, electrochlorination enables onsite production of the sodium hypochlorite required by the demand, by means of the following global chemical reaction:

$$
\mathrm{NaCl}+\mathrm{H}_{2} \mathrm{O} \rightarrow \mathrm{NaOCl}+\mathrm{H}_{2}
$$

This process is somewhat more costly than purchasing sodium hypochlorite due to the investment cost of the electrolysis cells, energy consumption, and maintenance costs.
Electrochlorination is largely used to treat the cooling water of large marine power stations in the UK, France, Italy and Spain. Recently, problems with mal function have led some power station operators to shift over to sodium hypochlorite or chlorine dioxide.

\subsubsection{Chlorine chemistry}

\section{Terminology}

When dissolved in natural waters, chlorine gas or a sodium hypochlorite solution produce different oxidizing compounds depending on the reaction of hydrolysis and oxidation of ammonia, leading to chloramines or bromamines. The oxidants also react with organic matter to produce chlorinated or brominated organics. As a result, water chlorination chemistry involves many molecular and ionic species or groups, whether oxidants or non-oxidants, whose terminology must be precisely defined.

Chlorine is described in the literature as 'free', 'active', 'available', 'combined' or 'residual' - or by a combination of these adjectives.

(a) Free chlorine/Free available chlorine (FAC) is present as an equilibrium mixture of hypochlorous acid $(\mathrm{HOCl})$ and hypochlorite ions $\left(\mathrm{OCl}^{-}\right)$. Both are oxidants, but $\mathrm{OCl}^{-}$is far less effective than $\mathrm{HOCl}$. Fugitive elemental chlorine can be ignored.

(b) Combined chlorine/Combined available chlorine is available in chloramines or other compounds having a N-C link; these are also oxidants. 
(c) Total available chlorine (TAC) is the sum of (a) and (b).

(d) Residual is analogous to Available, but serves to emphasize the concept of a pool of oxy-disinfectant capacity that persists after the initial demand (below) has been met. Hence : free residual chlorine, combined residual chlorine and total residual chlorine (TRC/TRO).

(e) Chlorine demand is defined as the difference between the amount of chlorine added (dosage) and the useful (residual) chlorine remaining at the end of a specified contact period. Demand is best considered as a once-off reaction that "mops up" a finite quantity of oxidizable substrate.

(f) Chlorine decay is a continuing series of reactions that will in time lead to the complete disappearance of all measurable chlorine. Decay, unlike demand, is not substrate-limited.

The toxicity of chlorinated water, and particularly its acute toxicity, is correlated with its oxidizing potential. It is suggested that for a chlorine species to have any significant efficacy as a biocide, it must have an oxidation-reduction or redox potential (ORP) sufficient to oxidize iodide to iodine at $\mathrm{pH} 7$. It is becoming more common and is, in many instances (e.g. seawater) is more correct, to refer to "oxidants" rather than to chlorine.

(g) Total Residual Oxidant (TRO). Most methods for determining "chlorine" actually measure oxidant capacity via the stoichiometric iodide/iodine route. For this reason alone, it is preferable to refer to total, free and combined residual oxidant rather than to total, free and combined residual chlorine in seawater where brominated oxidants are the dominant species. TRO is numerically and operationally equivalent to TRC and TAC as defined above.

(h) Chlorine Produced Oxidants (CPO) is a self-explanatory term, reminding us that oxidants occur naturally in many waters and that some will be measured as though they were CPOs. These will appear as 'background' in blank determinations but for most practical purposes their concentrations are so low that they can be ignored.

When using oxidant terminology, it is important to remember that the instrument or method used for measurement was almost certainly developed and calibrated for chlorine and that (strictly) the result should be expressed as "mg/L TRO as $\mathrm{Cl}_{2}$ ". Generally, the calibration curve is drawn for free chlorine in $\mathrm{HOCl}$-dominant solutions, which means that chloramines, bromamines and brominated oxidants are measured as free chlorine equivalents.

The concept of Available chlorine (as distinct from 'free available' and 'total available') is confusing and should be avoided wherever possible. It originated as a way of comparing bleaching agents, much as water hardness may be measured 'as $\mathrm{CaCO}_{3}$. The concept can be applied equally well to oxidants containing no chlorine at all (e.g. ozone) and to those whose chlorine does not hydro- 
lyze to produce hypochlorous acid (e.g. chlorine dioxide), but the calculations are heavily dependent upon knowledge of valence state during reaction conditions. Neither ozone nor chlorine dioxide are Available chlorine compounds - specifically chlorine compounds that hydrolyze to hypochlorous acid. This is therefore another term to be avoided. A similar source of error is the expression of biocide concentrations as, for example, $\mathrm{mg} / \mathrm{L}$ bromine. Such values must be reduced by the atomic weight ratio $33.5: 80$ to be directly comparable with chlorine oxidants.

To summarize, it is more precise and thus preferable in most situations to use the term residual oxidant prefaced by free, combined or total as appropriate, with "as $\mathrm{Cl}_{2}$ " implicitly understood.

Among the non-oxidizing chlorine by-products (CBPs) generated by reactions with organic matter, several categories have been defined.

a) Organohalogens (OX) designates organochlorinated or organobrominated compounds; altogether, these compounds constitute Total Organohalogens (TOX).

b) Purgeable Organohalogens (POX) designates volatile organohalogens. The trihalomethanes (THMs) represent a significant proportion of POX.

C) Adsorbable Organohalogens (AOX) designates organohalogens adsorbable on activated carbon. These are all the heavy (non-volatile) compounds as well as some volatile com- pounds not eliminated before dosage. If the AOX measurement is performed after elimination of the volatile compounds, AOX represents the non-volatile compounds, such that TOX $=$ AOX + POX.

d) Extractable Organohalogens (EOX) designates organohalogens extracted in an organic solvent. As for the AOX, some of the volatile compounds may persist in the extract, so that EOX represents the sum of nonvolatile compounds and some volatile compounds.

POX, AOX and EOX are global measurements obtained by microcoulometry of halogens. EOX was especially developed for measurements in solutions rich in chloride ions $(\geq 1$ $\mathrm{g} / \mathrm{L}$ ) and is used on chlorinated seawater.

CBPs also contain polar compounds (haloacetic acids) which are not measured by such methods.

Part of these CBPs can be identified and measured by gas or liquid or ion chromatography when calibration standards are available.

\section{Chemistry of chlorine in freshwater}

\section{Free oxidant chemistry}

The addition of chlorine (or sodium hypochlorite) to water can be viewed as an instantaneous reaction resulting in an equilibrium mixture of hypochlorous acid - $\mathrm{HOCl}$ and hypochlorite ions $\mathrm{OCl}$ :

$$
\begin{gathered}
\mathrm{Cl}_{2}+\mathrm{H}_{2} \mathrm{O} \leftrightarrow \mathrm{HCl}+\mathrm{HOCl} \\
\mathrm{HOCl} \leftrightarrow \mathrm{H}^{+}+\mathrm{OCl}^{-}
\end{gathered}
$$


Both are oxidants and comprise the free residual, but $\mathrm{OCl}^{-}$is far less effective as a biocide than $\mathrm{HOCl}$.

Decreasing the concentration of $\mathrm{H}^{+}$ ions (increasing the $\mathrm{pH}$ ) shifts the equilibrium towards $\mathrm{OCl}^{-}$, which is substantially less effective as a biocide than $\mathrm{HOCl}$.

The ionization constant also varies with temperature; the percentage of undissociated $\mathrm{HOCl}$ at temperatures between $0^{\circ} \mathrm{C}$ and $30^{\circ} \mathrm{C}$ over the $\mathrm{pH}$ range 5.0 to 11.7 , is summarized in Table 3.11.

Comparison of the percentage of undissociated $\mathrm{HOCl}$ as a function of $\mathrm{pH}$ is given in Figure 3.8.

The effect of ionic strength (or TDS concentration) on the dissociation of $\mathrm{HOCl}$ over the $\mathrm{pH}$ range 6.0 to 8.5 at $25^{\circ} \mathrm{C}$ is shown in Table 3.12 ; it should be noted that fully saline seawater contains around $32,000 \mathrm{mg} / \mathrm{L}$ TDS.

The influence of Ammonia : combined chlorine

Chlorination would follow the simple and predictable chemistry outlined above were it not for the presence in the water of nitrogenous compounds. Chlorine reacting with any amines (compounds containing the $\mathrm{N}$ atom with one or more hydrogen atoms attached) will form a molecule broadly classified as a chloramine or N-chloro compound. The terms "combined (residual) chlorine" or "combined (residual) oxidant" generally refer to such halogenated nitrogen compounds of which the most significant are the inorganic chloramines, formed by reac- tion with free ammonia. Relatively little is known about the formation or biocidal potential of organic chloramines, since organic amino nitrogen is generally far more abundant than ammonia.

The reaction with ammonia proceeds by sequential substitution of each of its hydrogen atoms. As such, the reactions are competitive and, for practical purposes, may be considered as irreversible:

$$
\mathrm{NH}_{3}+\mathrm{HOCl} \rightarrow \mathrm{NH}_{2} \mathrm{Cl}+\mathrm{H}_{2} \mathrm{O}
$$

(1)(monochloramine)

$$
\mathrm{NH}_{2} \mathrm{Cl}+\mathrm{HOCl} \rightarrow \mathrm{NHCl}_{2}+\mathrm{H}_{2} \mathrm{O}
$$

(2) (dichloramine)

$\mathrm{NHCl}_{2}+\mathrm{HOCl} \rightarrow \mathrm{NCl}_{3}+\mathrm{H}_{2} \mathrm{O}$

(3) (trichloramine/nitrogen trichloride)

The reactions are dominated by 5 factors: $\mathrm{pH}$, temperature, contact time, the initial ratio of chlorine: ammonia and, most importantly, by the initial chlorine and ammonia concentrations. The first reaction is almost instantaneous at $\mathrm{pH} 8.3$ and will convert all the free chlorine to monochloramine when the initial ratio is equimolar ( $5: 1$ by weight) or less. The other reactions are slower (several minutes), consistent with the decreased basicity of the chloramines. At higher chlorine: ammonia ratios, chloramines disappear and the TRC decreases to a minimum so-called "breakpoint" value theoretically located at the molar ratio of 1.5 (7.6 by weight) as shown in Figure 3.6.

These reactions, and the breakpoint phenomenon, are of fundamen- 
Table 3.11. - Variation in percentage of undissociated hypochlorous acid $(\mathrm{HOCl})$ with changing $\mathrm{pH}$ and temperature.

\begin{tabular}{|c|c|c|c|c|c|c|c|}
\hline $\begin{array}{c}\text { Temp } \\
\mathrm{pH}\end{array}$ & $0^{\circ} \mathrm{C}$ & $5^{\circ} \mathrm{C}$ & $10^{\circ} \mathrm{C}$ & $15^{\circ} \mathrm{C}$ & $20^{\circ} \mathrm{C}$ & $25^{\circ} \mathrm{C}$ & $30^{\circ} \mathrm{C}$ \\
\hline 5.0 & 99.85 & 99.82 & 99.80 & 99.79 & 99.74 & 99.71 & 99.68 \\
\hline 6.0 & 98.53 & 98.28 & 98.00 & 97.73 & 97.45 & 97.18 & 96.92 \\
\hline 6.5 & 95.50 & 94.75 & 93.96 & 93.16 & 92.37 & 91.60 & 90.87 \\
\hline 7.0 & 87.04 & 85.08 & 83.10 & 81.16 & 79.29 & 77.53 & 75.90 \\
\hline 7.2 & 80.91 & 78.25 & 75.64 & 73.11 & 70.73 & 68.52 & 66.52 \\
\hline 7.4 & 72.78 & 69.42 & 66.20 & 63.18 & 60.39 & 57.87 & 55.63 \\
\hline 7.6 & 62.79 & 58.89 & 52.27 & 51.98 & 49.03 & 46.43 & 44.17 \\
\hline 7.8 & 51.57 & 47.48 & 43.81 & 40.58 & 37.77 & 35.35 & 33.30 \\
\hline 8.0 & 40.18 & 35.32 & 32.98 & 30.12 & 27.69 & 25.65 & 23.95 \\
\hline 8.2 & 29.77 & 26.46 & 23.69 & 21.38 & 19.46 & 17.88 & 16.58 \\
\hline 8.4 & 21.10 & 18.50 & 16.38 & 14.64 & 13.23 & 12.07 & 11.14 \\
\hline 8.6 & 14.44 & 12.53 & 11.00 & 9.77 & 8.77 & 7.97 & 7.33 \\
\hline 8.8 & 9.62 & 8.29 & 7.23 & 6.39 & 5.72 & 5.18 & 4.75 \\
\hline 9.0 & 6.29 & 5.39 & 4.69 & 4.13 & 3.69 & 3.33 & 3.05 \\
\hline
\end{tabular}

Table 3.12. - Effect of the total dissolved solids (TDS) concentration on the percentage of undissociated $\mathrm{HOCl}$.
$25^{\circ} \mathrm{C} \quad{ }^{\top} \quad \mathrm{pH} 6.0$
$\mathrm{pH} 6.5$
$\mathrm{pH} 7.0$
$\mathrm{pH} 7.5$
$\mathrm{pH} 8.0$
$\mathrm{pH} 8.5$ TDS $\mathrm{mg} / \mathrm{L}$

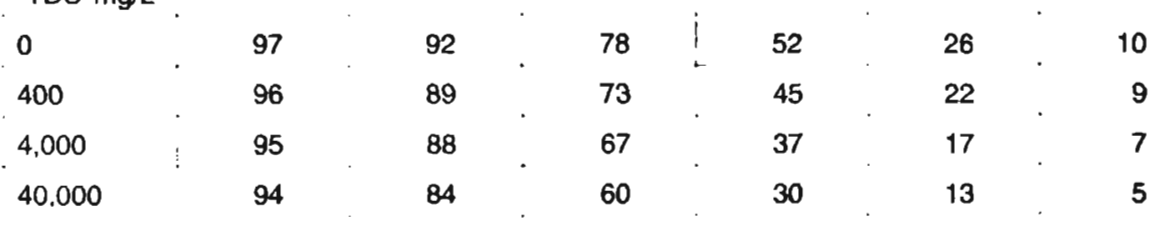

tal importance when treating natural freshwaters because the combined forms are less toxic (efficacious), but are more persistent than free chlorine. Chlorination by-products

Since the discovery of the halogenation of organic matter by Rook (1974), a wide range of compounds have been associated with the chlorination of freshwater for the production of drinking water and for the primary sterilization of effluents in sewage treatment (see Jolley et al., 1983 and other Chlorination conferences Jolley et al., 1976.1978, 1980, 1983, 1986, 1990). 


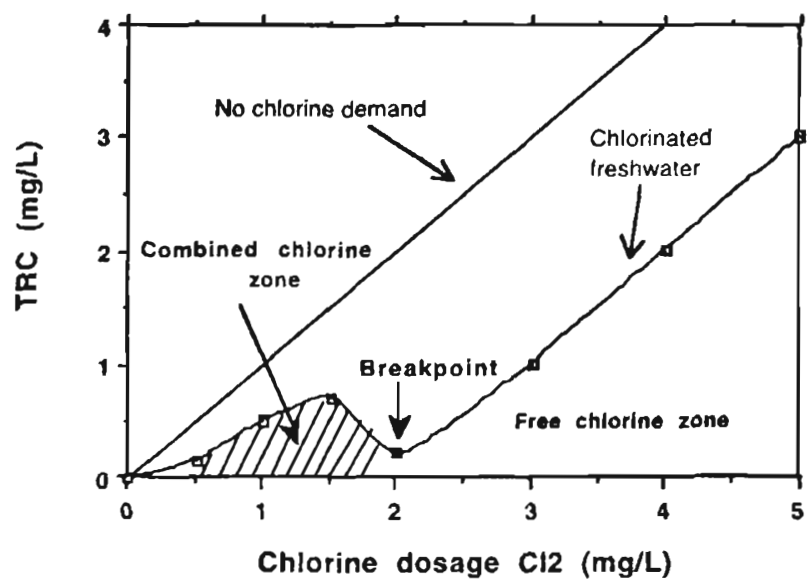

Fig. 3.6. - Example of a chlorination curve in freshwater containing ammonia.

The formation of organohalogenated compounds depends mainly on the organic matters present in all river and lake waters; the role of humic acids as precursors of THMs is well documented (Doré, 1989; Duvivier, 1993). On the other hand, chloramines produce less THMs, POX and AOX than free chlorine (Fig. 3.7). The major volatile compound is chloroform, but among the organics, many chlorinated compounds can be detected: chlorophenols, cyanogen chloride, chlororesorcinol, etc.

The U.S. EPA has proposed monitoring of selected CBPs when chlorine is used as a disinfecting agent for drinking water (Richardson 1997):

THMs.

Haloacetic acids, six HAAs (chloro-, dichloro-, trichloro-, bromo-, dibromo- and bromochloro- acetic acids).

Haloacetonitriles (dichloroacetonitrile and trichloroacetonitrile, bromochloroacetonitrile, dibromoacetonitrile).

Haloketones (1,1-Dichloropropanone, 1,1,1-trichloropropanone).

Chloral Hydrate.

Chloropicrine.

Finally, traces of bromates are found in sodium hypochlorite solutions; 2 to $5 \mathrm{mg} \mathrm{BrO}_{3}^{-}$per $\mathrm{g}$ of chlorine.

Chemistry of chlorine in seawaters

Free oxidant chemistry

When added to seawater, chlorine oxidizes the bromide ions $(68 \mathrm{mg} / \mathrm{L}$ bromide at full salinity), yielding hypobromous acid $(\mathrm{HOBr})$. This reaction is rapid, with $99 \%$ conversion within 10 


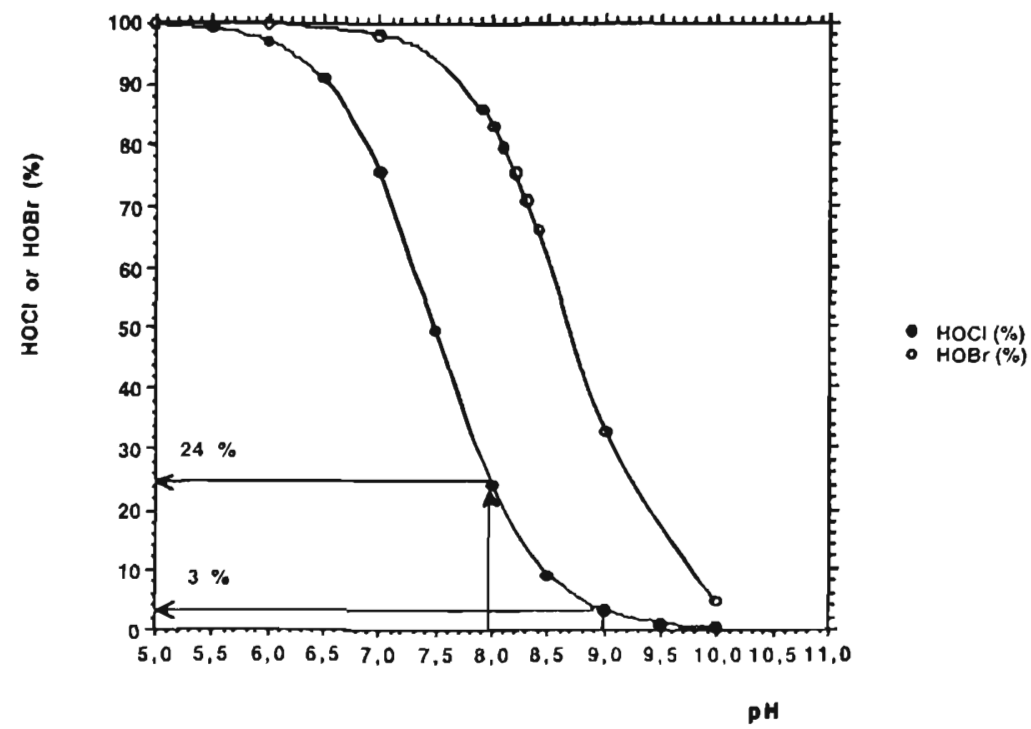

Fig. 3.8. - Comparison of the dissociation of hypochlorous acid and hypobromous acid with changing $\mathrm{pH}$ at $20^{\circ} \mathrm{C}$.

seconds at full salinity and within 15 seconds even at half salinity (Hergott et al., 1978).

$$
\mathrm{Br}-+\mathrm{OCl}^{-} \rightarrow \mathrm{Cl}^{-}+\mathrm{OBr}^{-}
$$

Thus in seawater, the free oxidants are predominantly composed of $\mathrm{HOBr}$ and the hypobromite ions $\mathrm{OBr}$

$$
\mathrm{HOBr} \leftrightarrow \mathrm{H}^{+}+\mathrm{OBr}-
$$

The dissociation of hypobromous acid depends on the same factors as the dissociation of hypochlorous acid, however the $\mathrm{HOBr}$ acid remains undissociated at higher $\mathrm{pH}$ values than for $\mathrm{HOCl}$ (Fig. 3.8). This implies that, at the $\mathrm{pH}$ of seawater (8.0 to 8.2), the free oxidant $(\mathrm{HOBr})$ is essentially undissociated and consequently more efficient as a biocide than the dissociated $\mathrm{OCl}^{-}$in the same range of $\mathrm{pH}$ in freshwater.
Where ammonia levels are high with respect to the chlorine dose, a competitive reaction of $\mathrm{HOCl}$ to ammonia leads to the formation of monochloramine $\left(\mathrm{NH}_{2} \mathrm{Cl}\right)$. Moreover, $\mathrm{HOBr}$ reacts rapidly with any $\mathrm{NH}_{2} \mathrm{Cl}$ that has been formed, yielding dibromamine $\mathrm{NHBr}_{2}$ and a bromine-based chemistry. In coastal seawater, the brominated compounds largely dominate but a mixed chlorine/bromine system can prevail at estuarine sites with varying salinity and ammonia levels.

In seawater containing ammonia, the combined oxidants formed by chlorination are monobromamine $\mathrm{NH}_{2} \mathrm{Br}$, dibromamine $\mathrm{NHBr}_{2}$ and tribromamine, and a breakpoint curve similar to that of freshwater is found in chlorinated seawater (Fig. 3.9). In this case however, the combined oxi- 


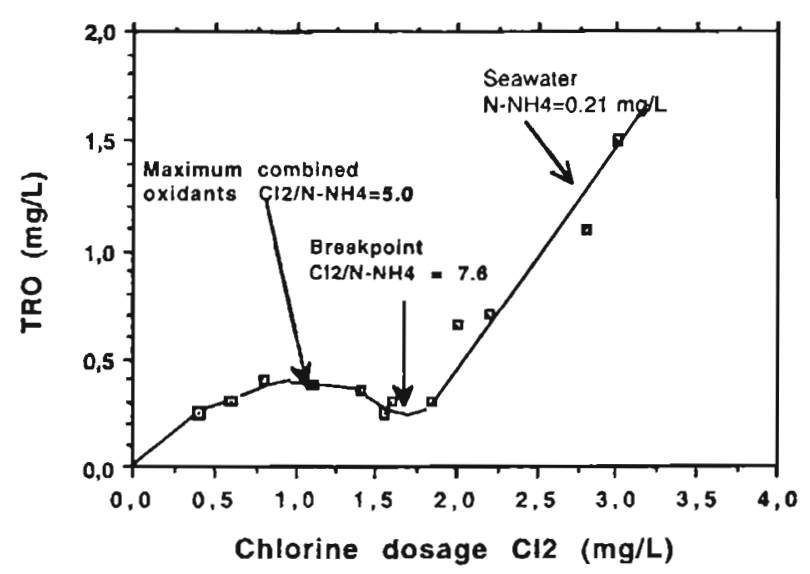

Fig. 3.9. - Experimental chlorination of seawater from the Gravelines power station intake canal. $\mathrm{N}$ - ammonia $=0.21 \mathrm{mg} / \mathrm{L}$, contact time $20 \mathrm{~min}$. (Allonier \& Khalanski 1997).

dants are brominated compounds but the chlorine: ammonia ratio is the same : 5.0 at the maximum of combined TRO and 7.6 at the breakpoint.

A second feature of bromine chemistry is that bromamines, unlike chloramines, interconvert rapidly and reversibly. $\mathrm{NHBr}_{2}$ decays rapidly, as does $\mathrm{NHCl}_{2}$, but unlike $\mathrm{NHCl}_{2}$ it does not form a persistent monohalamine at seawater $\mathrm{pH}$. This high oxidative reactivity leads to claims that bromocompounds are more potent biocides than their chlorine analogues.

\section{Formation of by-products}

In seawater, global analysis of EOX and POX gives poor results in the range of low concentrations $\leq 40$ $\mu \mathrm{g} / \mathrm{L}$ ), probably due to interference with chlorides (Allonier 1996). Chromatography is therefore needed to measure organohalogenated compounds in low concentrations.
The chemistry of oxidant species in seawater is dominated by brominated compounds and, consequently, the major organohalogenated compounds produced by chlorination of seawater are also brominated. Experimental data (Abarnou, 1979) have shown that the major THM is bromoform $\mathrm{CHBr}_{3}$, with a molar formation yield of a few $\%$ of added chlorine.

A long-term survey of the THM level at the Gravelines power station, operated by EDF on the North Sea coast, confirms this yield but shows consistent variations due to water quality changes and, more importantly, the ammonia content of the coastal water (Fig. 3.10).

The linear regression fitted on the data from Penly and Gravelines corresponds to a bromoform formation yield of $28.6 \mu \mathrm{g} / \mathrm{L}$ for a $1 \mathrm{mg} / \mathrm{L}$ injection of chlorine. The formation yield of bromoform, based on weight, is thus 


\section{Data from PENLY 1993-1996 and GRAVELINES 1995-1996.}

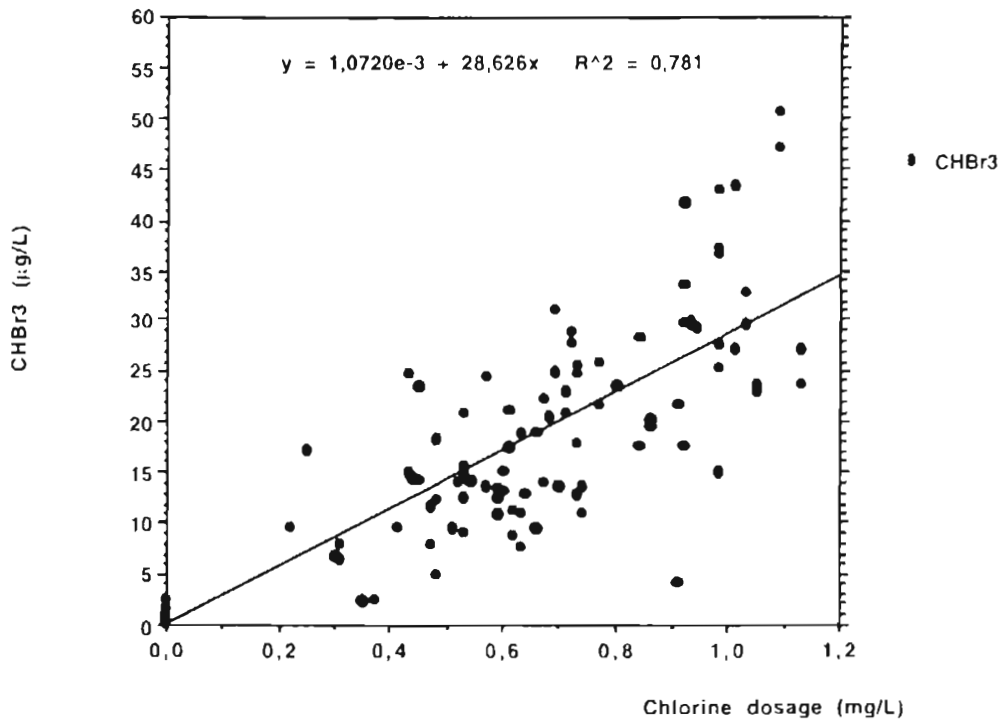

Fig. 3.10. - Bromoform in chlorinated seawater with changing chlorine dosage at the Penly and Gravelines power stations. Data from measurements taken by Institut Pasteur de Lille and the EDF Environment Department.

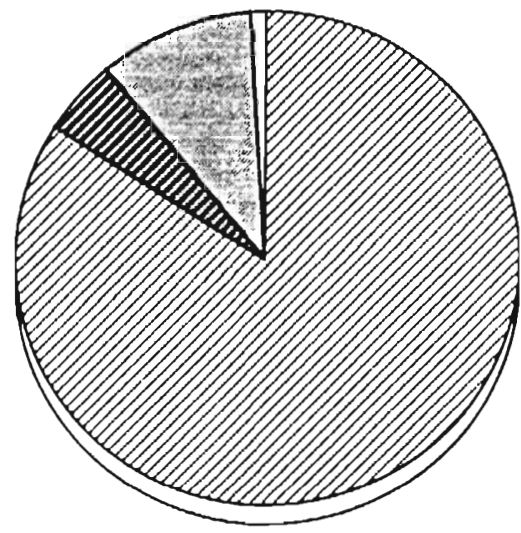

Z Bromoform $(84 \%)$

Eather Tritss $15 \%$

$\square$ DBAN (10 \%)

$\square \operatorname{TBP}(1 \%)$

Fig. 3.11. - Average distribution of organohalogens measured by gas chromatography in seawater chlorinated at $0.8 \mathrm{mg} / \mathrm{L}$ at the Gravelines power station. EDF DER data (Allonier \& Khalanski. 199.97) 
Table 3.13. - Bromoform and dibromoacetonitrile at the oufall of selected marine European power stations, mean $\pm 95 \%$. Chlorine dosage in the range of 0.3 to $1.5 \mathrm{mg} / \mathrm{L}$. (Jenner et al., 1997).

\begin{tabular}{|c|c|c|c|}
\hline Power station & Period & Bromoform $(\mu g / L)$ & DBAN $(\mu g / L)$ \\
\hline Heysham (UK) & $\begin{array}{r}11 / 08 / 92-15 / 12 / 92 \\
12 / 01 / 93-07 / 09 / 93\end{array}$ & $\begin{array}{l}29.20 \pm 24.25 \\
23.00 \pm 8.24\end{array}$ & $\begin{array}{l}3.15 \pm 3.59 \\
2.12 \pm 1.08\end{array}$ \\
\hline Dungeness (UK) & $03 / 08 / 93$ & 5.75 & 0.20 \\
\hline Wylfa (UK) & 21/09/93 & $27.00-27.50$ & $0.79-0.87$ \\
\hline Bradwell (UK) & $19 / 10 / 93$ & 25.00 & 0.87 \\
\hline Hartlepool (UK) & 17/08/93 & 3.50 & $<0.10$ \\
\hline Sizewell (UK) & $23 / 08 / 93$ & 14.50 & $<0.10$ \\
\hline Penly (France) & $\begin{array}{r}27 / 05 / 93-18 / 08 / 93 \\
21 / 06 / 94-27 / 07 / 94\end{array}$ & $\begin{array}{r}13.37 \pm 4.17 \\
15.01 \pm 3.22\end{array}$ & $\begin{array}{l}\text { NA } \\
\text { NA }\end{array}$ \\
\hline Paluel (France) & $14 / 10 / 92$ & $3.10-9.65$ & $0.10-1.05$ \\
\hline Gravelines (France) & $03 / 05 / 93-25 / 10 / 93$ & $18.63 \pm 3.70$ & NA \\
\hline : Maasvlakte (NL) & $\begin{array}{r}02 / 07 / 92-22 / 10 / 92 \\
16 / 05 / 93-10 / 08 / 93\end{array}$ & $\begin{array}{l}11.54 \pm 5.40 \\
8.35 \pm 12.35\end{array}$ & $\begin{array}{l}0.83 \pm 0.56 \\
0.94 \pm 1.22\end{array}$ \\
\hline
\end{tabular}

about $3 \%$ of chlorine dosage. The kinetics of THM formation in seawater is a more rapid process than in freshwater. About $80 \%$ of the final bromoform concentration is formed in three hours (Allonier \& Khalanski, 1997).

Using gas chromatography, only THMs, dibromoacetonitrile and tribromophenol were detected in seawater samples from the Gravelines power station, chlorinated at $0.8 \mathrm{mg} / \mathrm{L}$ (Allonier \& Khalanski 1997), giving the following average concentrations:

— bromoform : $24 \mu \mathrm{g} / \mathrm{L}$,

- dibromoacetonitrile

(DBAN) : $3 \mu g / L$,

— tribromophenol : $0.3 \mu \mathrm{g} / \mathrm{L}$.

The average distribution is given in Figure 3.11.
This evaluation does not take in account the haloacetic acids (HAA). Preliminary results indicate that the main HAA formed by sea water chlorination is dibromoacetic acid, at a level higher than DBAN. Nevertheless, bromoform remains the major organohalogenated compound formed by low-level chlorination of sea water $\left(\mathrm{Cl}_{2} \leq 1 \mathrm{mg} / \mathrm{L}\right)$.

In an effort to compare the range of compounds produced under conditions of on-load chlorination at power stations, a large-scale survey was undertaken in France, the Netherlands and the UK. The study was conducted between 1992 and 1994 with the express purpose of examining as wide as possible a range of water qualities used for cooling by power stations (Jenner et al., 1997). The data collected in this survey confirmed that the organohalogen produced in the lar- 
gest quantity was bromoform (Table 3.13).

The results from this survey show that point-of-discharge bromoform concentrations varied from $53.45 \mu \mathrm{g} / \mathrm{L}$ (Heysham) to $3.1 \mu \mathrm{g} / \mathrm{L}$ (Paluel) and dibromoacetonitrile concentrations from $11.39 \mu \mathrm{g} / \mathrm{L}$ (Heysham) to $0.1 \mu \mathrm{g} / \mathrm{L}$ (Paluel). Other compounds detected in the surveys at discharge were bromodichloromethane and dibromochloromethane, with concentrations of 0.8 and 0.7 $\mu \mathrm{g} / \mathrm{L}$ respectively at Maasvlakte and Heysham; 2,4,6-tribromophenol at $0.25 \mu \mathrm{g} / \mathrm{L}$ (Heysham) and $0.29 \mu \mathrm{g} / \mathrm{L}$ (Maasvlakte) and 2,4-dibromophenol at $0.055 \mu \mathrm{g} / \mathrm{L}$ (Dungeness). These large discrepancies can primarily be explained by differences in chlorine dosage or dilution with non-chlorinated cooling water, and secondly by differences in water quality.

\subsubsection{Measurement of residual oxidants}

Chlorine residuals may be measured in the laboratory using several techniques, including amperometric and potentiometric titration, colorimetric titration using the FAS-DPD (Ferrous ammonium sulfate/DPD) method and colorimetry. Field determinations are usually colorimetric since most titration equipment is insufficiently robust for field use; indeed, it can be argued that since titrimetrc methods offer little if any improvement in precision and accuracy over colorimetric methods, there is not much of a case to be made for them. Brief descrip- tions of the principal methods and their limitations are given in White (1986) and in APHA-AWWA-WPCF (1992).

The methods were developed for potable water where quality (colour, odour and taste) is almost as important as microbial purity. Consequently, great emphasis is attached to the ability of the various methods to discriminate between the products of chlorination, particularly between free and combined forms. These distinctions are largely irrelevant to cooling water chlorination - and even to environmental monitoring - where the merits of the various methods may be judged on the more basic criteria of practicability and reliability. Information on a probe designed for combined measurements of biofilm growth and chlorine dosage is given on section 3.11.

DPD is the only colorimetric method capable of differentiating chlorine residuals; Syringaldazine is responsive only to free residuals. In the absence of iodide ions, free available chlorine reacts instantly with DPD to produce a red colour. Subsequent addition of a small amount of iodide causes monochloramine to produce colour, while addition of excess iodide activates dichloramine as well. Since iodide is already present in seawater, it follows that free 'chlorine' cannot be estimated without some breakthrough from halomines.

All small portable water test kits now on the market will handle chlorine by colorimetric DPD. The great advantage of portable kits is that the 
samples can be tested without delay, which is of crucial importance in view of the loss of chlorine from seawater samples through decay reactions. DPD reagents are available as compressed tablets in foil or as sachets of powder. The tablets are stable for a year or more, depending on conditions of storage, but should be discarded if the white tablet shows brown or greasy mottling. Liquid reagents are no longer available commercially prepacked in dropper bottles but can be made up from stock. The shelf life of the DPD component is comparable with that of tablets.

Small photometers using a standard $10-15 \mathrm{~mm}$ cell can theoretically read down to $0.01 \mathrm{mg} / \mathrm{L}$ TRO (10 $\mathrm{mg} / \mathrm{L})$. Visual comparison, using $113 \mathrm{~mm}$ path length Nessler cells, also reads down to $0.01 \mathrm{mg} / \mathrm{L}$ TRO but it is possible to extrapolate a value $0.01 \mathrm{mg} / \mathrm{L}$ TRO (i.e. TRO between zero and 0.01). The FAS-DPD titration has a lower limit of $18 \mathrm{mg} / \mathrm{L}$. Potentiometric titration limits depend very much on the type of electrode employed but are around $10 \mathrm{mg} / \mathrm{L}$. Amperometric titration can be improved from $30 \mathrm{mg} / \mathrm{L}$ (manual titration) to 10 $\mathrm{mg} / \mathrm{L}$ with a recorder and to $2 \mathrm{mg} / \mathrm{L}$ with a polarograph.

In practice, several factors complicate measurement of residual oxidants in natural waters:

- interferences: most methods for determining TRO are sensitive to other compounds present in the water such as metals or oxidants that have neither antifouling value nor potential for environmental harm; in the Loire, the interferences measured by colorimetric DPD reach $0.15 \mathrm{mg} / \mathrm{L}$ TR;

- turbidity and water colour are of particular importance for the use of colorimetric methods;

- water temperature: the response of electrochemical methods depends on the water temperature and, to a certain extent, on the conductivity of the water.

As a result, laboratory calibrations are generally much better than field measurements due to the respective sensitivity and accuracy of the methods. In practice, the quantitative measurement threshold for colorimetric DPD can generally not be lower than $0.02 \mathrm{mg} / \mathrm{L}$ in $\mathrm{FRC}$; it frequently happens that the variability of the blank gives a threshold of $0.05 \mathrm{mg} / \mathrm{L}$. While electrochemical methods always produce a signal related to the oxidants present in the sample to be analyzed, they also have limitations in natural waters, and the theoretical threshold of $0.01 \mathrm{mg} / \mathrm{L}(10 \mu \mathrm{g} / \mathrm{L})$ is rarely reached.

Due to these limitations, it is recommended to perform a series of field measurements in order determine the quantitative threshold corresponding to natural waters of a given quality.

\section{Continuous monitoring}

Regulatory authorities are in favour of continuous records for discharges - particularly as an adjunct to selfmonitoring. At present, there would appear to be no really satisfactory instrument for use with raw freshwater, 
let alone seawater. Some instruments are totally unsuited to seawater use, either by virtue of materials or process. The instrument must be capable of accommodating variations in salinity, temperature and suspended solids and, at the lower TRO levels, must be able to withstand bacterial slimes growing on their internals or be self cleaning. Nearly all the instruments currently available can be made to work; there is, however, a world of difference between this labourintensive situation and continuous monitoring. The lower limits of detection are effectively $0.05-0.10 \mathrm{mg} / \mathrm{L}$ (50-100 $\mu \mathrm{g} / \mathrm{L})$. The concept of using monitoring not merely for simple recording but actually for reliable feedback control of chlorine injection is therefore not realistic.

There do, however, exist analyzers based on semi-continuous colorimetric DPD measurement of free and total oxidants which give satisfactory results. The devices must nonetheless be regularly checked, the tanks cleaned and the measurement systems recalibrated.

\subsubsection{Experimental data on the efficacy of chlorine}

\section{Freshwater biofouling}

Bacterial slime

Continuous low-level chlorination was found effective in tests carried out from July to November with Lake Erie water at concentrations as low as TRC $=0.1 \mathrm{mg} / \mathrm{L}$ (Ewans et al., 1992). In this experiment, discontinuous chlorination treatments for 30 minutes every 12 hours was not effective : substantial biofilm growth was seen at all dosages from $0.5 \mathrm{mg} / \mathrm{L}$ to $1.5 \mathrm{mg} / \mathrm{L}$.

\section{Zebra mussels}

Much experimental data is available on the effect of different protocols in treatment of zebra mussels : continuous, intermittent and shock chlorination.

Table 3.14 gives the data on continuous low-level chlorination. These data, presented graphically in Figure 3.12 , clearly show an influence of water temperature on the exposure time needed to kill from $90 \%$ to $100 \%$ of the Zebra mussels. It must nonetheless be noted that, even at very low temperatures $\left(0-4{ }^{\circ} \mathrm{C}\right)$, chlorination causes partial mortality in the long term.

Age has little influence on the lethal dose: juveniles (1 to $5 \mathrm{~mm}$ ) respond like adults (> $10 \mathrm{~mm}$ ). Considerable differences are observed in the experimental results, particularly at the lowest concentrations.

Furthermore, the minimum exposure time reaches a plateau at 5 to 7 days at the highest concentrations and temperatures. For water temperatures $\geq 15^{\circ} \mathrm{C}$, a continuous exposure time of 3 weeks kills all the exposed mussels.

Data from Van Benschoten et al. (1993) on mortality of zebra mussels exposed to a TRC level of $0.5 \mathrm{mg} / \mathrm{L}$ indicate that the $95 \%$ mortality level is reached in about 42 days at $10^{\circ} \mathrm{C}$, but in only 7 days at $25^{\circ} \mathrm{C}$. The following equation has been fitted for 
Table 3.14. - Mortality of adult and juvenile zebra mussels exposed to continuous lowlevel chlorination.

Experimental conditions ITR $(\mathrm{mg} / \mathrm{L}) \mid$

Thames River. Adults

$\mathrm{T}=10^{\circ} \mathrm{C}$
$\mathrm{T}=10^{\circ} \mathrm{C}$
$\mathrm{T}=10^{\circ} \mathrm{C}$
$\mathrm{T}=21^{\circ} \mathrm{C}$
$\mathrm{T}=21^{\circ} \mathrm{C}$
$\mathrm{T}=21^{\circ} \mathrm{C}$

Seine river

Shell length : $28-30 \mathrm{~mm}: 1.0$

$\mathrm{T}=22^{\circ} \mathrm{C}$

\section{Meuse river. Adults}

$\mathrm{T}=14.5^{\circ} \mathrm{C}$

The Netherlands.

Adults

$\mathrm{T}=12$ to $15^{\circ} \mathrm{C}$

Niagara river. Adults

$\mathrm{T}=9.0$ to $15.0^{\circ} \mathrm{C}$

$\mathrm{T}=9.0$ to $15.0^{\circ} \mathrm{C}$

$\mathrm{T}=9.0$ to $15.0^{\circ} \mathrm{C}$

$\mathrm{T}=18.0$ to $21^{\circ} \mathrm{C}$

Sheil length : $10-15 \mathrm{~mm}$

$\mathrm{T}=12$ to $15^{\circ} \mathrm{C}$

$\mathrm{T}=12$ to $15^{\circ} \mathrm{C}$

$\mathrm{T}=17$ to $27^{\circ} \mathrm{C}$

$\mathrm{T}=17$ to $27^{\circ} \mathrm{C}$

$\mathrm{T}=17$ to $27^{\circ} \mathrm{C}$

Shell length : $14-16 \mathrm{~mm}$

$\mathrm{T}=7.2$ to $17.5^{\circ} \mathrm{C}$

$\mathrm{T}=7.2$ to $17.5^{\circ} \mathrm{C}$

$\mathrm{T}=4.8$ to $9.5^{\circ} \mathrm{C}$

$\mathrm{T}=4.8$ to $9.5^{\circ} \mathrm{C}$

$\mathrm{T}=4.8$ to $9.5^{\circ} \mathrm{C}$

Shell length : $2-6 \mathrm{~mm}$

$\mathrm{T}=20$ to $22{ }^{\circ} \mathrm{C}$

! $\mathrm{T}=20$ to $22{ }^{\circ} \mathrm{C}$

$\mathrm{T}=20$ to $22^{\circ} \mathrm{C}$

$\mathrm{T}=20$ to $22^{\circ} \mathrm{C}$

Shell length : $2.5 \mathrm{~mm}$

$\mathrm{T}=8$ to $12^{\circ} \mathrm{C}$

$\mathrm{T}=10$ to $11.5^{\circ} \mathrm{C}$

$\mathrm{T}=21.5$ to $24.0^{\circ} \mathrm{C}$

Shell length:

$0.75-2.0 \mathrm{~mm}$

$\mathrm{T}=8$ to $12{ }^{\circ} \mathrm{C}$

Lake Erie. Adults

$\mathrm{T}=0$ to $4{ }^{\circ} \mathrm{C}$

5.0

0.5

2.0

0.5

1.1
1.5

0.25

0.5

1.0

3.0

0.62

4.3

9.02

0.5

2.5

5.0

1.0

1.0

0.3 to

0.5
Exposure time $t$ (days) Mortality rate $M(\%)$

$t=7 d \quad M=5 \%$

$t=7 d \quad M=20 \%$

$t=7 d \quad M=40 \%$

$t=7 d \quad M=40 \%$

$t=7 d \quad M=70 \%$

$t=7 d \quad M=100 \%$

$t=19$ d $M=99 \%$

$t=15 d \quad M=99 \%$

$t=12 d \quad M=99 \%$

Reference

- Greenshield \& Riedley, 1957

$\begin{array}{ll}1.0 & t=12 d \\ 0.1 & \text { to } 10.0 \\ M & =99 \%\end{array}$

$t=\left(-9.69^{*} \log T R C\right)+11.92$

$\mathrm{t}=44 \mathrm{~d} \quad \mathrm{M}=0 \%$

$t=41 d \quad M=65 \%$

$t=35 d \quad M=83 \%$

$t=21 \mathrm{~d} M \geq 90 \%$

$t=16 \mathrm{~d} \quad M 93 \%$

$1.0 \quad t=14$ d M $95 \%$

Jenner, 1985

Garric \& Migeon, 1983

Gillet \& Micha, 1985

$t=27 d \quad M=50 \%$

$1.0 \quad t=27$ d $M=100 \%$

$0.5 \quad t=9 d \quad M=100 \%$

De Girolamo et al., 1991

in Van Benschoten et al., 1993

$t=17 d M=93 \%$

$t=17 d \quad M=93 \%$

$t=15 d \quad M=95 \%$

$t=9 d \quad M=100 \%$

$t=5 d \quad M=100 \%$

$t=6 \mathrm{~d} \quad M=100 \%$

Klerks \& Fraleigh, 1991

0.32

$t=54 d \quad M=50 \%$

$t=32 d \quad M=50 \%$

$t=17$ d $M=50 \%$

$t=25 d M=50 \%$

$t=20 d \quad M=50 \%$

$\underline{t=20} d M=50 \%$

$t=20$ d $M=7 \%$

$t=13 d \quad M=100 \%$

$t=9 d \quad M=100 \%$

$t=7 d \quad M=100 \%$

$M=100 \%$

$t=28 d \quad M=70 \%$

$0.6 \pm 0.2 \quad t=15 d \quad M=40 \%$

$0.6 \pm 0.2 \quad t=8 d \quad M=100 \%$

Martin et al., 1990

$t=25$ d $M=100 \%$

$t=27 d \quad M=30 \%$
Van Benschoten et al., 1993 


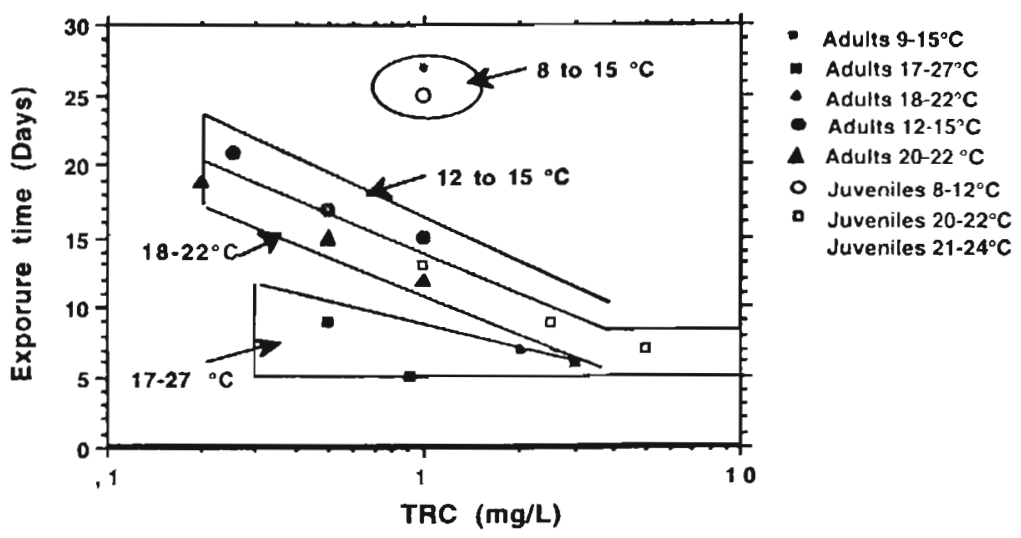

Fig. 3.12. - Exposure time required to kill 90 to $100 \%$ of Zebra mussels exposed to continuous chlorination from data in Table 3.14.

temperatures of $0{ }^{\circ} \mathrm{C}$ to $25^{\circ} \mathrm{C}$ (Fig. 3.13) :

LOG $\left(\mathrm{LT}_{95}\right)=3.458-0.0486 * \mathrm{~T}$

LT $_{95}$ : exposure time to achieve $95 \%$ mortality in days, $\mathrm{T}=$ water temperature in ${ }^{\circ} \mathrm{C}$.

The effectiveness of the combined use of heat and oxidants - chlorine and ozone - to control adult Zebra mussels has been investigated by Harrington et al. (1997). It is possible to reduce the exposure time by heating the water to higher temperatures. At $30{ }^{\circ} \mathrm{C}$, the time required to reach $95 \%$ mortality at a chlorine concentration of $0.5 \mathrm{mg} / \mathrm{L}$ is one day; at $34^{\circ} \mathrm{C}$, it is only one hour (Fig. 3.13).

At the Ontario Hydro experimental facility located on Lake Erie at Nanticoke, experiments were conducted at different intermittent chlorination regimes (Ewans et al., 1992). This study produced extremely interesting results, later applied to Ontario Hydro installations.
Continuous treatments at TRC $\geq$ $0.3 \mathrm{mg} / \mathrm{L}$ was efficacious: no attachment of mussels was observed in the experimental flow-through cells.

Discontinuous treatment (half an hour every 12 hours) was not effective even at higher chlorine dosages: TRC of $0.5 \mathrm{mg} / \mathrm{L}$ to $1.5 \mathrm{mg} / \mathrm{L}$. This type of discontinuous chlorine regime also failed to kill the mussels at a Cleveland Electric Illuminating Company installation on Lake Erie with a TRC of $0.3 \mathrm{mg} / \mathrm{L}$ for 28 days (Barton, 1990).

Experiments with semi-continuous treatments have shown good results at $T R C=0.5 \mathrm{mg} / \mathrm{L}$ with "high-frequency treatments" : 15 minutes on/15 minutes off and 15 minutes on/30 minutes off. On the other hand, as soon as the "off" time reaches $60 \mathrm{mi}-$ nutes, efficacy drops (Wiancko \& Claudi, 1994).

Some physiological responses of juvenile and adult zebra mussels to 


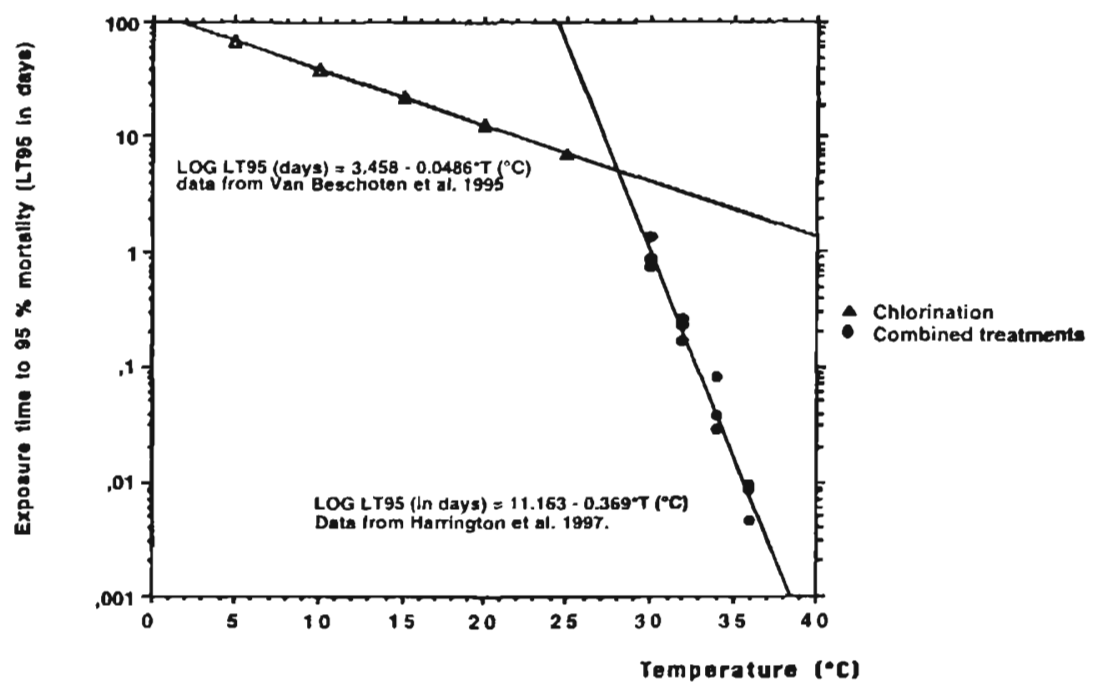

Fig. 3.13. - Exposure times to reach $95 \%$ mortality of adult zebra mussels depending on the water temperature. Triangles: chlorination at $0.5 \mathrm{mg} / \mathrm{L}$ on mussels acclimated to the test temperature, according to data of Van Benschoten et al. (1993). Circles: combined effects of $0.5 \mathrm{mg} / \mathrm{L}$ chlorination and heat shocks in the range of 30 to $36^{\circ} \mathrm{C}$ on mussels acclimated from 5 to $25^{\circ} \mathrm{C}$, according to data of Harrington et al. (1997).

low-level chlorination $(0.1$ to $1.0 \mathrm{mg} / \mathrm{L})$ have been investigated by Van der Velde et al. (1997), who measured the filtration rate, the foot activity, the byssus thread production and the strength of byssus threads at $20^{\circ} \mathrm{C}$. All physiological activities are affected by continuous exposure to chlorine with a dose-dependent relationship in the range of 0.1 to $0.5 \mathrm{mg} / \mathrm{L} \mathrm{TRC}$. The filtration rate is reduced by $50 \%$ at $0.3 \mathrm{mg} / \mathrm{L}$ and up to $90 \%$ at $0.5 \mathrm{mg} / \mathrm{L}$ (Fig. 3.14). Juvenile mussels are slightly more affected than the adults. The filtration rate remains very low at 1.0 $\mathrm{mg} / \mathrm{L}$ TRC : $5 \%$ to $9 \%$ of the control.

Shock chlorination has been tested by Khalanski (1993) on adult zebra mussels (17-22 mm). In this static ex- periment, it was necessary to apply two successive shocks of 24 hours each, at $200 \mathrm{mg} / \mathrm{L}$ chlorine dosage, to kill $100 \%$ of the tested mussels over 9 days. In 24 hours, the chlorine concentration decreased from 200 $\mathrm{mg} / \mathrm{L}$ to $30 \mathrm{mg} / \mathrm{L}$.

\section{Asiatic clam}

According to Dohorty et al. (1986) and Ramsey et al. (1988), C. fluminea could be killed by continuous chlorination for two to three weeks at concentrations of $0.5 \mathrm{mg} / \mathrm{L}$ total residual chlorine (TRC). It must be noted that water temperatures were relatively high $\left(20-25^{\circ} \mathrm{C}\right)$. 
Table 3.15. - Data on zebra mussel attachment on flow-through cells after exposure to intermittent chlorination regimes. (Evans et al., 1992, Wiancko \& Claudi, 1994). The values in parentheses correspond to percentages of attached mussels after 10 weeks compared to the control.

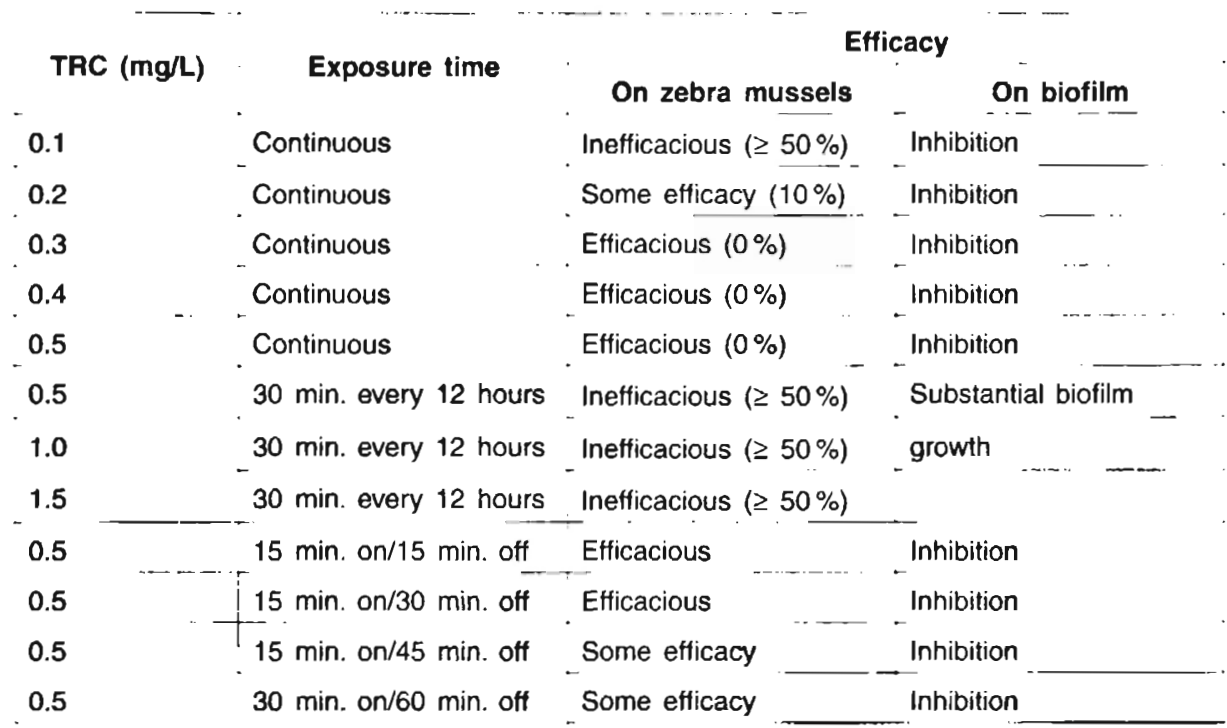

\section{Brackish waters}

On the brackish mussel Mytilopsis, exposure times for $100 \%$ mortality with chlorination show a size-dependent effect; $2-\mathrm{mm}$ mussels require 29 days and $10-\mathrm{mm}$ mussels, 36 days using $1.0 \mathrm{mg} / \mathrm{L}$ TRO (Table 3.16). Filtration rate, foot activity and byssus thread production were reduced in proportion to the increase of the applied chlorine dose below $1.0 \mathrm{mg} / \mathrm{L}$ TRC (Rajagopal et al., 1994). This species is significantly more resistant to chlorination than the mussel, Brachidontes striatulus; tests in Madras (India) also showed a high resistance to chlorine (Table 3.16).
Marine mussels Mytilus edulis and Mytilus galloprovincialis

Trials using continuous chlorination in the range of $0.2-1.0 \mathrm{mg} / \mathrm{L}$ total residual oxidant (TRO) showed that total mortality requires periods of treatment between 15 and 135 days, according to Lewis (1983 a and b). (Fig. 3.16).

Temperature was the driving parameter in this toxicity model when TRO fell below $1.0 \mathrm{mg} / \mathrm{L}$. Data based on this model show an almost tenfold decrease in the time required to kill when comparing mortality at 10 and $25{ }^{\circ} \mathrm{C}$ (Table 3.17). 
Table 3.16. - Data on lethal chlorine doses for two species of brackish water bivalves.

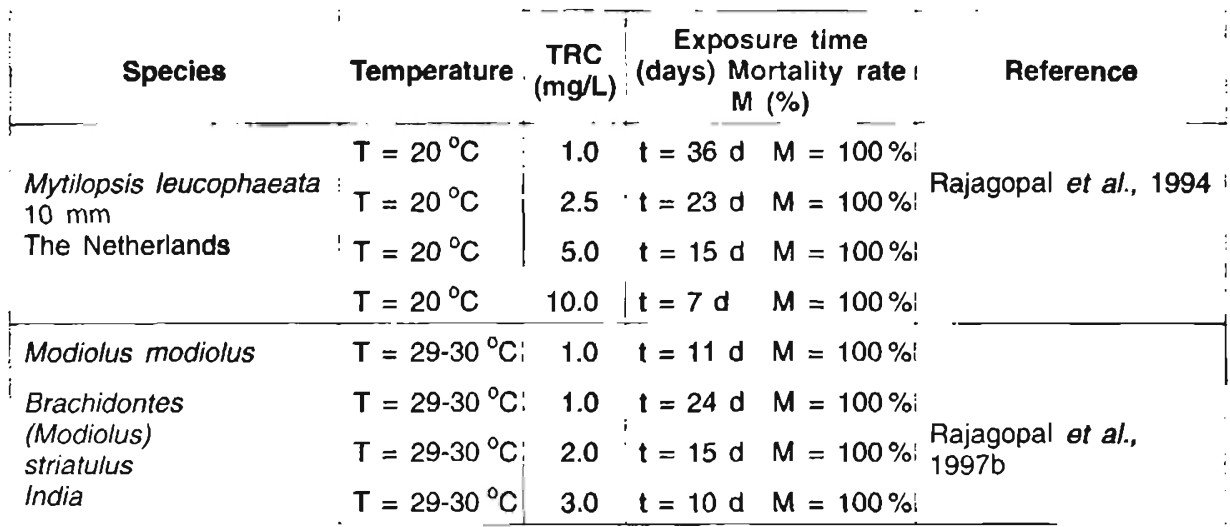

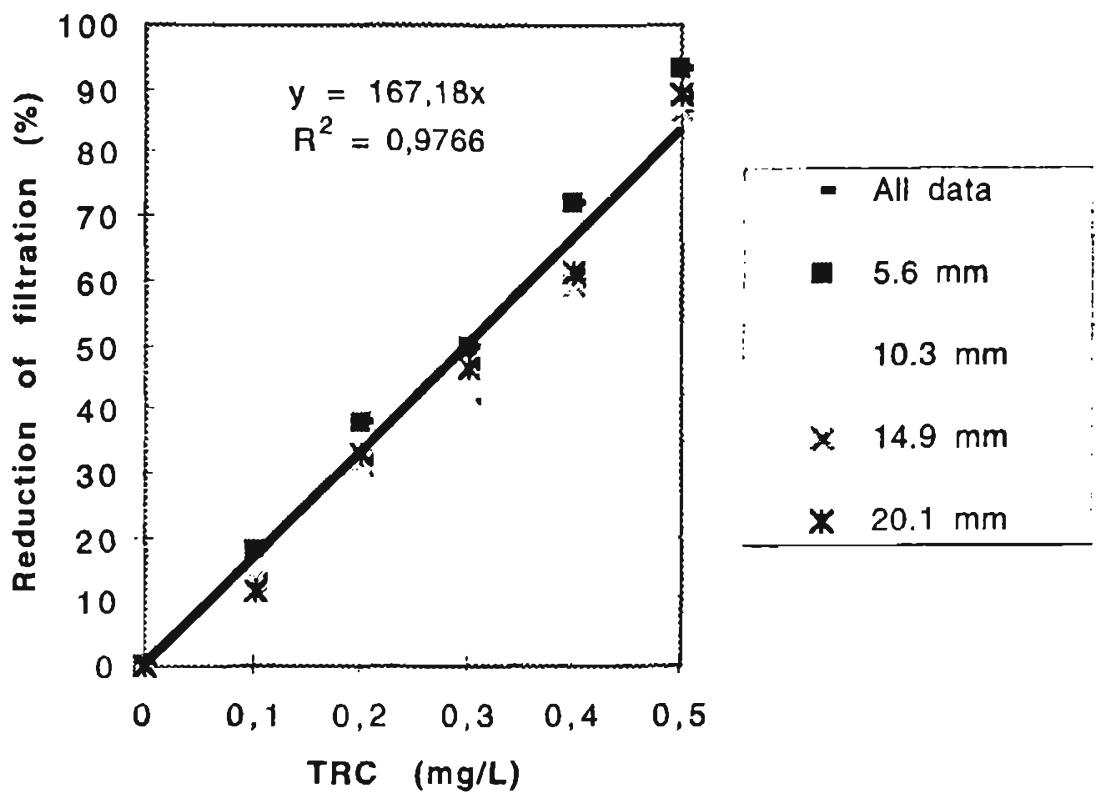

Fig. 3.14. - Effect of water chlorination on the filtration rate of Dreissena polymorpha juveniles $(5.6 \mathrm{~mm})$ and adults $(10.3$ to $20.1 \mathrm{~mm})$ at $20^{\circ} \mathrm{C}$. Redrawn from data of Van der Velde et al., (1997).

A comparative study of the efficacy of two chlorination levels was conducted at the Gravelines plant from May to November in 1983 and 1984 (Tra- vade \& Khalanski, 1986). During this field experiment, settlement, growth and mortality of larvae were monitored in spat monitors supplied with wa- 
Table 3.17. - Data for the time (in days) required for $100 \%$ mortality at various temperatures and two TRO levels, from Lewis (1983a).

\begin{tabular}{|l|c|c|c|c|}
\hline Temperature $\left({ }^{\circ} \mathrm{C}\right)$ & 10 & 15 & 20 & 25 \\
\hline TRC & & & & \\
\hline $0.2 \mathrm{mg} / \mathrm{L}$ & 788 & 369 & 172 & 81 \\
\hline $0.4 \mathrm{mg} / \mathrm{L}$ & 451 & 211 & 99 & 46 \\
\hline
\end{tabular}

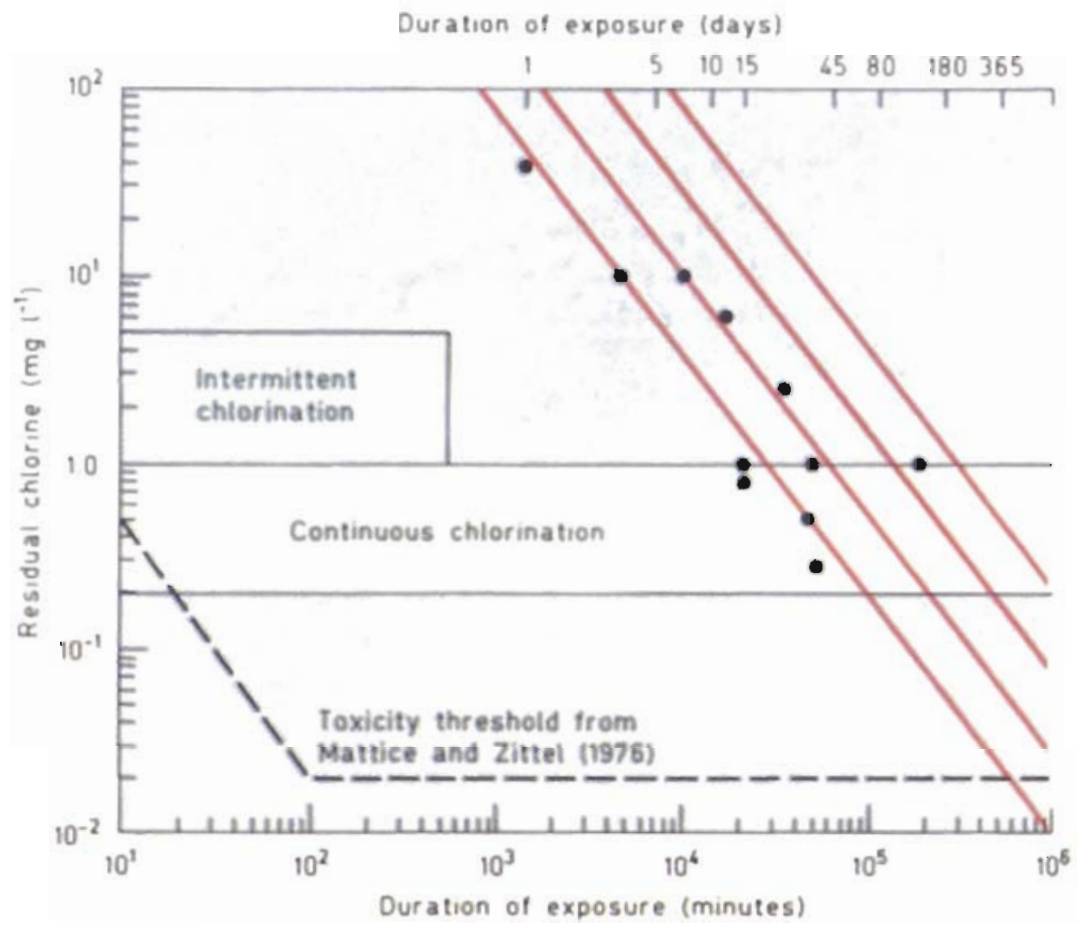

Fig. 3.16. - Plot of TRO against time for continuous chlorination regimes (injection level) with zone of $100 \%$ mortality indicated by lines of temperature for residual and exposure (after Lewis, 1983 $a, b)$.

ter taken from two circuits chlorinated at $0.8 \mathrm{mg} / \mathrm{L}$ and $0.4 \mathrm{mg} / \mathrm{L}$ with mean TRO concentrations of respectively $0.49 \mathrm{mg} / \mathrm{L}$ and $0.29 \mathrm{mg} / \mathrm{L}$. The results summarized in Table 3.18 confirm Lewis's model of adult mussels: they survive in the long term (5 months) when exposed to relatively high TRO levels, even though growth is stopped.

On the other hand, observations using spat monitors show clearly that recently settled mussels are far more 
Table 3.18. - Comparison of the efficacy of two continuous low-level dosages over a 150-day period on Mytilus edulis spat and adults at Gravelines (Travade \& Khalanski, 1986).

\begin{tabular}{|c|c|c|c|c|c|c|}
\hline \multirow[b]{2}{*}{$\begin{array}{c}\text { Chlorine } \\
\text { dosage } \mathrm{mg} / \mathrm{L}\end{array}$} & \multirow[b]{2}{*}{ TRO $\mathrm{mg} / \mathrm{L}$} & \multicolumn{3}{|c|}{ Spat $(<5 \mathrm{~mm})$} & \multicolumn{2}{|c|}{ Adults (> $10 \mathrm{~mm}$ ) } \\
\hline & & Settlement & Growth & $\begin{array}{l}\text { Detachment } \\
\text { and mortality }\end{array}$ & Growth & Mortality \\
\hline 0.8 & 0.49 & none & none & $\begin{array}{l}90 \text { to } 95 \% \\
\text { in } 20 \text { days. } \\
100 \% \text { in } 30 \\
\text { days. }\end{array}$ & none & $\begin{array}{l}\leq 25 \% \text { in } \\
150 \text { days. }\end{array}$ \\
\hline 0.4 & 0.29 & $\begin{array}{l}\text { less than in } \\
\text { the control }\end{array}$ & none & $\begin{array}{l}50 \text { to } 71 \% \\
\text { in } 15 \text { days. } \\
\leq 30 \% \\
\text { remain } \\
\text { settled in } \\
150 \text { days. }\end{array}$ & no data & $\begin{array}{l}\text { no significant } \\
\text { mortality in } \\
150 \text { days. }\end{array}$ \\
\hline
\end{tabular}

sensitive to residual oxidants : spat do not grow and a large proportion detach or die in 20 to 30 days at 0.49 $\mathrm{mg} / \mathrm{L} \mathrm{TRO}$; at $0.29 \mathrm{mg} / \mathrm{L}$ TRO, growth is also inhibited and half the spat detach in 15 days, though up to $30 \%$ still remain in 150 days. In conclusion, continuous chlorination in low concentrations is more effective on recently settled juveniles than on adults; it should be performed as soon as they begin to attach. Continuous treatment with a TRO of $0.1 \mathrm{mg} / \mathrm{L}$ for one week in the spring, during the period of mussel ( $M$. edulis) larva settlement, is sufficient to reduce the density of spat fifteenfold, according to experiments conducted at the Astoria power station (NY, U.S.A.). In these tests, barnacles (Balanus eburneus) proved more resistant to chlorination than mussels (Sarunac et al., 1994).

Continuous low-level chlorination (dosage $\leq 1.0 \mathrm{mg} / \mathrm{L}$ ) has the effect of eliminating mussels due to two processes (Khalanski \& Bordet, 1981):
- a major decrease in the water filtration rate, which deprives the mussels of food,

- progressive intoxication by oxidant compounds absorbed with the small amounts of seawater necessary to survival of the mussels.

Measurements performed on adults show that the filtration rate is reduced by $60 \%$ at TRC $=0.2 \mathrm{mg} / \mathrm{L}$. In 35 to 45 days at this dosage, we find a $70 \%$ decrease in the growth rate of juveniles, according to Bucaille (1981) (Fig. 3.17).

In continuous low-level chlorination, the effect is to reduce filtration and thus food intake and cause the mussels to use up their food reserves and tissues until their body weight is so reduced that they are unable to continue filtration and die.

The availability of food for mussels, and for filter-feeding organisms in general, determines to a large degree their resistance to chlorination. In a 


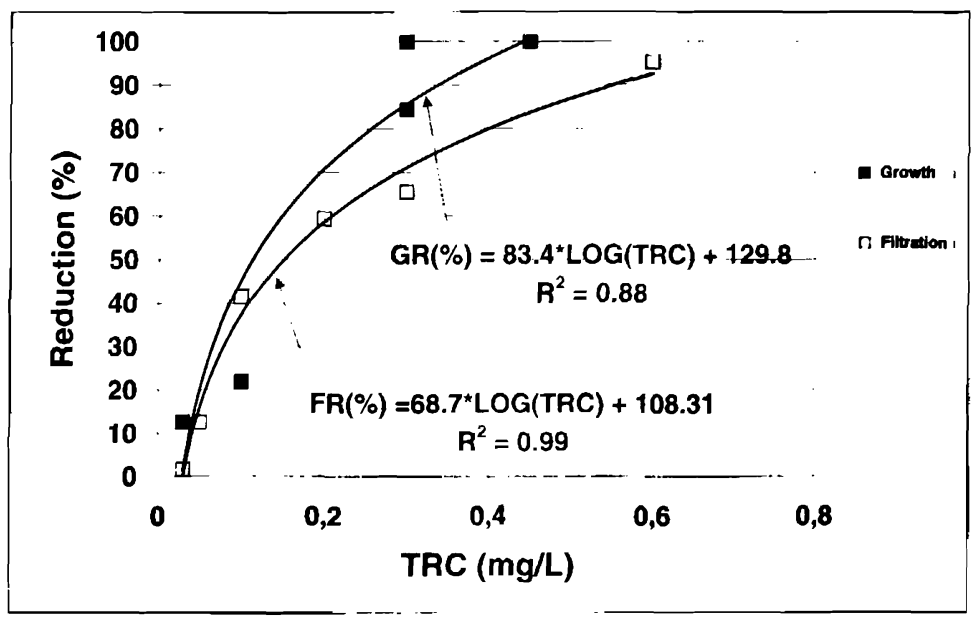

Fig. 3.17. - Reduction of the filtration rate for adults and growth reduction for juvenile blue mussels (Mytilus edulis) exposed for 35 to 45 days to continuous chlorination. Redrawn from previous data by Khalanski (1995).

food-rich environment, the mussels can withstand a substantial reduction of their filtration rate while maintaining rapid growth, and this is the case in certain coastal areas. In water with scant food supply, any reduction in filtration activity will affect growth.

The most favourable conditions for the development of mussel populations are eutrophicated waters, as found in some parts of the English Channel and the North Sea coasts. The Mediterranean coasts are normally very poor in food for filter-fee- ding organisms but some harbour areas, such as La Spezia, Naples and Brindisi in Italy, are very rich and suitable for mussel growth.

\section{Intermittent chlorination}

In waters rich in food particles, discontinuous treatments of a few hours per day or a few days per month at high concentrations ( 3 to $5 \mathrm{mg} / \mathrm{L}$ ) do not kill mussels, which merely close their shells during the treatment.

On the other hand, semi-continuous treatments can kill mussels in nourishment-poor waters due to trophic limitation: an 8-hour treatment each day can be sufficient to halt mussel growth.

Finally brief, frequently repeated chlorine shocks are extremely disturbing for mussels, as they do not recover their filtration capacity immediately following the shock (Khalanski \& Bordet, 1981). To optimize the effect of reduced filtration, it is advisable to suspend treatment for less than one hour, which corresponds to experimental findings for zebra mussels (Wiancko \& Claudi, 1994).

In 1997-1998, KEMA developed a new system to optimize a chlorination regime called Pulse-chlorination ${ }^{\mathfrak{B}}$. This system is based on the exact 
measurement of the valve movement behaviour of mussels with the Mosselmonitor ${ }^{\circledR}$. Pulse-chlorination ${ }^{\circledR}$ uses the recovery period of the mussel species to be mitigated. By short chlorination periods, alternating with periods without chlorine (i.e. recovery periods), the mussels will experience the total period as continuous chlorination. Reduction in hypochlorite is possible of $50 \%$, and even $75 \%$ reduction is expected, compared with continuous chlorination.

\section{Barnacles}

As there are several species of barnacles which colonize surfaces in cooling systems, those for which treatment data are available will be mentioned on a species-by-species basis. First, unnamed adults tolerated residuals of $1.0 \mathrm{mg} / \mathrm{L}$ for up to 15 days, though $75 \%$ of them survived only 5 days (Turner et al., 1948). Elminius modestus, showed growth inhibition at chlorine residuals of 1.0 $\mathrm{mg} / \mathrm{L}$ and above, with partial growth limitation at $0.5 \mathrm{mg} / \mathrm{L}$, leading to the deduction that free chlorine in excess of $0.5 \mathrm{mg} / \mathrm{L}$ causes heavy mortalities and a marked reduction in growth of survivors (Waugh 1964). This agrees with other data showing $80 \%$ average mortalities using Balanus improvisus with 5 -minute exposures to $2.5 \mathrm{mg} / \mathrm{L}$ total chlorine (McLean 1973). In general, it has been found throughout Europe that when mussels are controlled by chlorination, no operational problems are caused by barnacles.

\subsubsection{Chlorine use at industrial sites}

\section{Bacterial slime in cooling water systems}

Cooling water circuits of power stations on rivers are generally equipped with on-line sponge ball cleaning systems which control bacterial slime perfectly.

At marine sites, bacterial slime in heat exchangers is controlled using different types of treatments depending on the potential growth of bacteria.

In France, continuous low-level chlorination at $\geq 0.2$ TRC at the inlet of the heat exchangers is efficient during the spring and summer months (May to November) at the EDF power stations located on the English Channel. Using this procedure to eliminate macro-biofouling, no additional cleaning system is required at these sites. However, in areas where the bacterial slime is very high, as in some harbours or at Gravelines on the French North Sea coast, it is necessary to combine continuous low-level chlorination with an on-line sponge ball cleaning system.

Discontinuous treatments are efficient in waters with low amounts of organic matter, as at the EDF Martigues-Ponteau power station on the Mediterranean coast, where a chlorine dosage at $3.0 \mathrm{mg} / \mathrm{L}$ for one hour every eight hours was successfully applied. At the Maasvlakte power station, Rotterdam, a semi-continuous treatment ( 4 hours on/4 hours off) at 0.2 to $0.3 \mathrm{mg} / \mathrm{L}$ TRC is used to control 
both macro- and micro-biofouling. According to the experience of KEMA in the Netherlands, micro-biofouling can be generally controlled by dosing hypochlorite at $0.5 \mathrm{mg} / \mathrm{L} \mathrm{TRC}$ for $30 \mathrm{mi}-$ nutes a day. A specific condenser biofouling treatment has been designed by EPRI, so-called "targeted chlorination", consisting in injecting a relatively high chlorine dose $(1 \mathrm{mg} / \mathrm{L}$ TRC) at the inlet of the condenser for a few minutes each day (Mussali et al., 1985). The water box of the condenser is divided into zones; injection nozzles are placed in each zone to treat the tubes in that zone selectively. The zones are chlorinated alternately and the chlorine consumption can be reduced by more than $80 \%$ compared to conventional mass chlorination (Thompson et al., 1994). This system is perfectly suited to protection of condensers, but has the disadvantage of not protecting other parts of the cooling circuit, especially against macrobiofouling.

\section{Shock chlorination \\ of recirculating circuits}

In large natural cooling towers, algae tend particularly to develop in three areas:

- on the inner surface of the shell, all the wet parts exposed to some light are covered with a layer Cyanobacteria (Blue-green algae) whose detachment during the shutdowns leads to a great input of organic matter in the packing,

- on the parts of the honeycomb packing structure exposed to light, essentially at the base; here again, they are Cyanobacteria in addition to filamentous green algae and a great deal of microalgae,

- in cold-water basins, on all concrete walls and pillars, Cyanobacteria and filamentous green algae can be very abundant.

In the 1980s at inland power stations operated by the CEGB in the UK, periodic changes of the packing elements within the tower shell were carried out to reduce the exposure time of packing to light. Discontinuous chlorination is the second control method used by CEGB. For this type of treatment, it is necessary to raise the water level in the tower ponds so there is no need to add make-up water or to purge the system during the course of treatment. When the water is at its highest operational level, hypochlorite is added to give a residual of $2.5 \mathrm{mg} / \mathrm{l} \mathrm{TRC}$ to be maintained over a period of 24 hours or until the residual level has fallen to the permitted discharge level (Blank 1984). This method kills the outer layers of the encrusting algae, turning the filaments white, but does not kill the deepest layers of horizontal filaments adhering to the timber slats. When the dead filaments have been washed off, the horizontal filament system is once again exposed to the flow of cooling water and growth begins again.

A discontinuous mass chlorination process was implemented by EDF to prevent or eliminate algae in the coldwater basins. To avoid the discharge of residual chlorine and to ensure more efficient cleaning, the blowdown is shut down for a few hours and 
Table 3.19. - EDF mass chlorination procedure used in some cooling towers to eliminate algae (Lutz \& Merle, 1983).

\begin{tabular}{|l|l|}
\hline \multicolumn{1}{|c|}{ TREATMENT STEPS } & \multicolumn{1}{c|}{ TIMING } \\
\hline $\begin{array}{l}\text { Set-up } \\
\text { - Make-up flow stopped } \\
\text { - blowdown suppressed } \\
\text { - water level lowered in the basin }\end{array}$ & 2 to 3 hours \\
\hline $\begin{array}{l}\text { Hypochlorite injection } \\
\text { Dosage } 20 \text { to } 40 \mathrm{mg} / \mathrm{L} \text { as chlorine }\end{array}$ & 10 to 30 minutes \\
\hline $\begin{array}{l}\text { Oxidant decay } \\
\text { Down to } 0.1 \mathrm{mg} / \mathrm{L} \text { as free residual chlorine } \\
\text { Duration dependent on fouling and operating temperature } \\
\text { Water level regulation through intermittent makeup }\end{array}$ & $\begin{array}{l}\text { From } 6 \text { hours in hot water } \\
\text { to hours in cold water }\end{array}$ \\
$\begin{array}{l}\text { Analytical control } \\
\text { Using DPD colorimetric method }\end{array}$ & Semi-continuous measurements \\
\hline $\begin{array}{l}\text { Return to normal service } \\
\text { Continuous make-up flow }\end{array}$ & $<1$ hour \\
\hline
\end{tabular}

make-up flow is regulated to balance the loss through evaporation and maintain a constant level in the basin (Lutz \& Merle, 1983). The typical process of this type of mass chlorination treatment is described in Table 3.19.

Mass chlorination is used to control algae as required at EDF-operated power stations : once a year on average, one or two treatments are performed at three sites. The chlorine concentration can be decreased at some sites, where $8 \mathrm{mg} / \mathrm{L}$ is sufficient. This type of mass chlorination was also performed in Belgium to clean the packing of a cooling tower fouled by organic deposits.

Continuous and semi-continuous treatments on freshwater

Experimental data have shown that, depending on water temperature and condition of the mussels, Dreissena polymorpha, the Zebra mussel, can be killed in a few weeks with continuous low-level chlorination (Fig. 3.12). As Jenner \& Janssen-Mommen (1993) explain, it is recommended to chlorinate at water temperatures $15^{\circ} \mathrm{C}$ to keep the duration of treatment as short as possible, but the threshold temperature can be lowered to $12{ }^{\circ} \mathrm{C}$ according to some industrial experience in the Netherlands. If we assume that "low-level" means TRC from 0.2 to $0.5 \mathrm{mg} / \mathrm{L}$, the following envelope for the duration of continuous chlorination treatment can be proposed :

For water temperatures $\geq 12^{\circ} \mathrm{C}$

- at TRC of 0.2 to $0.3 \mathrm{mg} / \mathrm{L}$, the treatment time is 28 days,

- at TRC of 0.4 to $0.5 \mathrm{mg} / \mathrm{L}$, the treatment time is 21 days. 
The chlorination period should be scheduled at the end or after the reproduction period to ensure that no 'new' spat will enter the system.

In the Netherlands, continuous lowlevel chlorination is used to treat large cooling water systems in petrochemical plants and power stations for two to four weeks after the mussel settlement period; this treatment, called "autumn chlorination", begins in midSeptember (Jenner 1985, Jenner \& Janssen-Mommen, 1993).

At the Monroe drinking water plant and the Monroe power station on Lake Erie, continuous chlorination at 0.5-0.6 mg/L TRC has been applied from June to November to eliminate Zebra mussels (Lepage 1993, Kovalak et al., 1993).

Hydro Quebec implemented periodic chlorination at the Beauharnois Hydropower plant, with two 30-day treatment periods, in spring and autumn, at a dosage of $2 \mathrm{mg} / \mathrm{L}$ TRC.

All dead mussels are small enough to pass through the cooling system without blocking the condenser tubes. Care should be taken in situations when the mussels are clustered and, after death, fall from the wall in small clumps and block the tubes. Even after death, the mussel shells are clustered because the byssus is not degraded. If settlements are dense and successional, there is a danger that one treatment will not be sufficient to protect the cooling system, so additional chlorination treatments may be necessary.
At the Dampierre-en-Burly power station on the Loire, equipped with cooling towers, a two-month (July-August 1996) continuous chlorination with a TRC of $0.3 \mathrm{mg} / \mathrm{L}$ resulted in total elimination of bryozoans, Zebra mussels and gastropod molluscs (Physa and Bithynia) from the cold water basins.

The treatment can be optimized and adapted to a given site by means of biomonitoring. A spat monitor can detect settlement peaks in the intake water and the chlorination time can be reduced by monitoring the survival of samples of mussels in test cells.

Since 1994, semi-continuous chlorination has been implemented at Ontario Hydro plants to eliminate Zebra mussels using the following procedure developed on the basis of experimental findings :

- chlorine dosage: $\mathrm{TRC}=0.5$ $\mathrm{mg} / \mathrm{L}$,

- chlorine addition regime : $30 \mathrm{mi}-$ nutes on, 45 minutes off,

- treatment throughout the Zebra mussel growing season.

Control of macro-biofouling in marine cooling water systems

As is clear from experimental data, the treatment procedure must be designed in light of two major criteria :

- the reproduction period, which determines larval settlement for a more or less long period in the year,

- the growth rate, which determines the size reached by the organisms by a given time after settlement. 
These two biological processes are dependent on the thermal regime; in the English Channel, for example, barnacles settle in early spring, sooner than the mussels which begin to settle at the end of spring. It has been shown that growth of natural mussel populations does not start until the seawater temperature is above $12^{\circ} \mathrm{C}$ (Bayne (ed.), 1976). This winter growth halt is mainly due to immersion of the mussels at low tide. Populations settled in cooling water circuits which are constantly underwater may have strong winter growth rates.

\section{Continuous low-level chlorination}

Water temperature is often adopted as the criterion for starting and stopping continuous low-level chlorination in the Channel and the North Sea. Continuous chlorination is performed in EDF-operated plants for as long as the temperature of the seawater exceeds $10^{\circ} \mathrm{C}$ or $12^{\circ} \mathrm{C}$, with a chlorine dosage of 0.5 to $1.0 \mathrm{mg} / \mathrm{L}$ depending on the site. The objective is to keep a TRC level of 0.2 to $0.4 \mathrm{mg} / \mathrm{L}$ at the inlet to the condensers and auxiliary exchangers. This represents a long period of treatment: 7 to 8 months per year in the Channel and North Sea.

The use of low-level dosing has important consequences for the operational staff in power stations. It is evident that the dosing equipment must be well-maintained in order for the supply of chlorine, from whatever source, to be sustained for periods of at least 200 days per year. As breakdowns are inevitable but usually unforeseen, guidance is required on the outage times permitted for completing maintenance of the dosing equipment. This is not a problem, provided the total time without chlorine in any annual dosing period does not exceed 30 days. Within this annual outage total, no single outage exceeding 15 consecutive days without chlorination is allowed. This maximum allowance is related to the growth of newly-settled mussels, which will not reach a length greater than $10 \mathrm{~mm}$ in 15 days and therefore will not block condenser tubes (19.0-mm diam.).

Auxiliary circuits are generally protected by means of chlorinated water derived from the main cooling system. It is recommended to ascertain that the residual chlorine level remains below the minimum required concentration. If this is not the case, the best solution is to have separate chlorine injection systems for the auxiliary circuits (Whitehouse et al., 1987).

These are of two main types, offshore and onshore intakes. In the case of offshore intakes, there are one or more tunnels of varying length and the chlorine distribution pipework is usually located as close to the point of ingress of the water as possible; the water transit time to the condenser generally exceeds 20 minutes. Where onshore intakes are used, the water transit time from the distribution point to the condenser inlet is about 5 to 10 minutes. This means that the dose needed at the onshore intakes will be lower than that used for offshore intakes. 
Engineering design recommendations for implementation of chlorination at marine power stations may be found in Whitehouse et al., 1985. Among these, the following should be noted:

- the distribution device must be placed at the water intake far enough upstream of the fixed bar screens to give adequate protection,

- all injectors must distribute the same quantity at all dosing points,

- at the dosing point, the best achievable mixing of the hypochlorite solution in the cooling water is required to avoid zones with low chlorine concentrations,

- the injection rate must be adjustable, requiring in turn that the flow and the concentration be measured with good precision.

\section{Semi-continuous chlorination}

The DOW Chemicals plant at Terneuzen (the Netherlands), located on the Escault estuary north of Antwerp, uses three types of antifouling treatments on cooling circuits : semi-continuous low-level chlorination of circuits with constantly flowing water, targeted chlorination of the tubular heat exchangers and intermittent chlorination of still water zones. The regime for semi-continuous chlorination is 30 minutes on / 30 minutes off with a TRC of 0.2 to $0.3 \mathrm{mg} / \mathrm{L}$.

The fact that high-frequency semicontinuous chlorination reduces the amount of chlorine needed prompted EDF in 1997 to change the conti- nuous chlorination regime at Flamanville to the following semi-continuous regime : 30 minutes on / 30 minutes off at $0.5 \mathrm{mg} / \mathrm{L}$. The limited growth of mussels on this site is a positive element in favour of this regime, which was found to be effective, saving $50 \%$ of chlorine from May to November.

At the Maasvlakte power station in Rotterdam, semi-continuous hypochlorite dosing, 4 hours on / 4 hours off, is applied when the water temperature is above $12^{\circ} \mathrm{C}$, with a TRC of 0.25 to $0.35 \mathrm{mg} / \mathrm{L}$ at the condenser inlet. Continuous dosing is applied when mussel spat are detected, using a spat collector. The mussel settlement period is usually June-July on the Dutch coast. After the mussel spat period, chlorination returns to a semicontinuous regime (4 hours on / 4 hours off). Chlorination is stopped when the water temperature falls below $12{ }^{\circ} \mathrm{C}$.

\section{Discontinuous chlorination}

At the Martigues-Ponteau plant on the French Mediterranean coast, a discontinuous chlorination protocol has been implemented with success on both Mytilus galloprovincialis and bacterial slime:

- from November to April, sodium hypochlorite injection for one hour per day at 2.5 to $3.0 \mathrm{mg} / \mathrm{L}$,

- from May to October, sodium hypochlorite injection for one hour every eight hours at 2.5 to $3.0 \mathrm{mg} / \mathrm{L}$. 


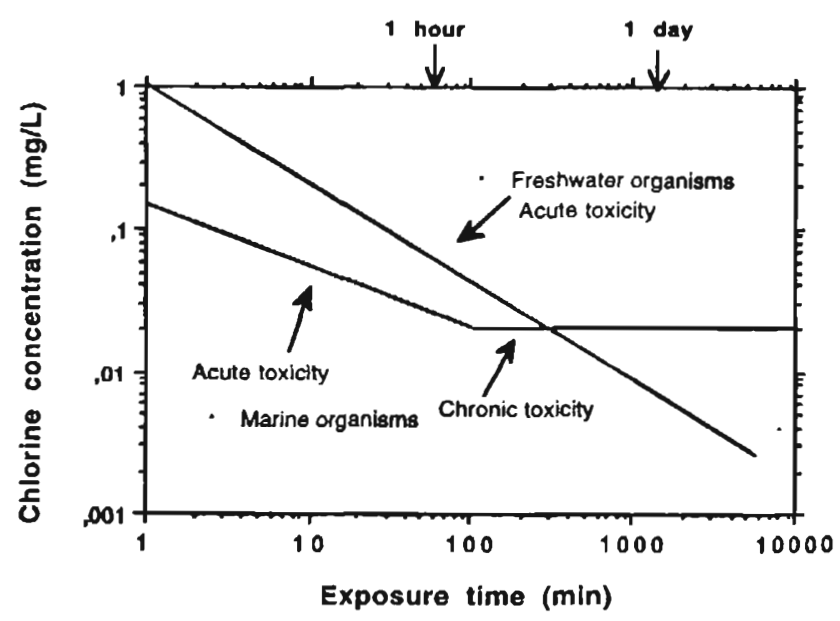

Fig. 3.18. - Toxicity thresholds for aquatic organisms exposed to residual chiorine (Mattice \& Zittel, 1976).

The success of this treatment is due to the low growth rate of macrobiofouling species, and especially of mussels, on this site with scanty nourishment for bivalves.

At other sites, however, discontinuous treatments have failed (Anderson \& Richards, 1966) due to the rapid growth rate of local mussel populations. At the Dunkerque plant on the French North Sea coast, for example, chlorination was performed from 1969 to 1971 according to the following protocol (Lagouche \& Guillon, 1976) :

- two periods of continuous chlorination at $1.0 \mathrm{mg} / \mathrm{L}$ at the injection point, from May 15 to June 20 and from September 1 to October 15,

- the rest of the year, two 20-minute injections per day at $5.0 \mathrm{mg} / \mathrm{L}$.

In 1971 at this plant, $360 \mathrm{~m}^{3}$ of mussels (Mytilus edulis) had to be removed from the pumping station and the water intake tunnel. Since then, continuous low-level chlorination has been performed from May to November.

\subsubsection{Environmental assessment of chlorination}

The complex chemistry of chlorine in natural waters was discussed earlier (paragraph 3.7.1.2) and two major categories of compounds were distinguished: oxidants and non-oxidants. The distinction between these two chemical categories is important to the evaluation of ecotoxicological risk. They have neither the same lifetime, nor the same capacity for bioaccumulation, nor the same toxicity for aquatic organisms.

Oxidants disappear more rapidly than non-oxidants; they are not bioaccumulated, but are nonetheless toxic in low concentrations. Chlorine 
Table 3.20. - Some bromoform bioaccumulation factors in freshwater fish.

\begin{tabular}{lc}
\multicolumn{1}{c}{ Species } & Bioaccum \\
Lepomis macrochirus & 0.8 \\
Lepomis macrochirus & $0.2-0.4$ \\
Micropterus salmoides & 0.5 \\
Cat fish & $0.5-0.6$ \\
Common trout & $0.5-1.0$ \\
& \\
by-products - CBPs - are, in the \\
main, more persistent; some are ac- \\
cumulated in animal fats; they are not \\
toxic in the short term, but some are \\
mutagens and carcinogenic.
\end{tabular}

\section{Freshwater chlorination}

Chlorination of freshwaters leads to the formation of essentially chlorinated compounds.

Chlorine consumption in river water due to reactions with ammonia and dissolved organic matters is high, and a rapid decay of the TRC is observed in chlorinated waters. In once-through cooling circuits treated by low-level chlorination, at a TRC $\leq 0.5 \mathrm{mg} / \mathrm{L}$ at the heat exchanger inlet, the residual at the circuit outlet does not generally exceed $0.1 \mathrm{mg} / \mathrm{L}$. In the mass chlorination procedure used for cooling towers, recirculation for 3 to 6 hours also reduces the TRC to $0.1 \mathrm{mg} / \mathrm{L}$, which is the regulation limit. Dilution in the river water causes a rapid decrease of TRC and residual chlorine is not measurable by conventional methods in the discharge plume.

Mattice \& Zittel (1976) reviewed the toxicity data of residual chlorine to aquatic organisms and proposed acute and chronic toxicity thresholds (Fig. 3.18). Although the chronic toxicity threshold is very low $(2 \mu \mathrm{g} / \mathrm{L})$ and non-realistic in terms of measurement, dilution and chemical consumption of residual chlorine is normally high enough to eliminate risks of toxicity.

The main organohalogenated compounds identified in natural waters are chlorinated trihalomethanes, chloracetic acids and chlorophenols; they represent, however, only a part of the total organohalogens found with the AOX method. We shall therefore take a succinct look at the question of the environmental impact of these different categories of organohalogenated compounds.

Chloroform $\mathrm{CHCl}_{3}$, the main THM formed by chlorination of natural freshwaters, disappears rapidly from the water, passing into the atmosphere. Its half-life - the time needed to halve its concentration in the water - has been estimated at 36 hours in a large river, 40 hours in a relatively shallow body of water, and from 9 to 10 days in a lake. Chloroform is degraded by photolysis in the atmosphere, whereas the processes causing disappearance of chloroform 
Table 3.21. - Some aquatic toxicity data on bromoform.

\begin{tabular}{|c|c|c|c|}
\hline Species & $\begin{array}{c}\text { Toxicity } \\
\text { parameter }\end{array}$ & $\begin{array}{c}\text { Concentration } \\
(\mathrm{mg} / \mathrm{L})\end{array}$ & Reference \\
\hline \multicolumn{3}{|l|}{ Bacteria } & \\
\hline Pseudomonas putida & Toxicity threshold & 125 & \\
\hline Cyanobacteria & & & \\
\hline Microcystis aeruginosa & Toxicity threshold & 185 & \\
\hline \multicolumn{4}{|l|}{ Green algae } \\
\hline Scenedesmus quadricauda & Toxicity threshold & 1100 & \multirow[t]{7}{*}{ Verschueren, 1983} \\
\hline Protozoa & & & \\
\hline Entosiphon sulcatum & Toxicity threshold & $>6590$ & \\
\hline Uronema parduczi & Toxicity threshold & $>6590$ & \\
\hline \multicolumn{3}{|l|}{ Fish } & \\
\hline Poecilia reticulata & $\mathrm{LC}_{50}, 14$ days & 102 & \\
\hline Carp embryo & $\mathrm{LC}_{50}, 96$ hours & 161 & \\
\hline Oyster larvae & & & \multirow[t]{2}{*}{ Trabalka et al., 1980} \\
\hline Crassostra virginica & $\mathrm{LC}_{50}, 48$ hours & 1 & \\
\hline
\end{tabular}

Table 3.22. - Selected toxicity data for monochloracetic acid to freshwater organisms (Verschueren, 1983).

Species Toxicity parameter Concentration $(\mathrm{mg} / \mathrm{L})$

Oligochaete worms Tubifex tubifex Toxicity threshold 150

Protozoa

Vorticella campanula

Toxicity threshold

9 Crustacea

Gammarus pulex

Toxicity threshold

30

Insects

Chironomus plumosus

Toxicity threshold

Fish

Trout

Salmo trutta iridea

Toxicity threshold

20

Carp

Cyprinus carpio

Toxicity threshold

14 
in the water (hydrolysis, photodegradation, biodegradation) are negligeable. Very little bromoform is adsorbed on suspended matter and sediments; bioaccumulation is also very limited (Table 3.20).

Toxicity bioassays show that bromoform has very low toxicity for bacteria, algae and freshwater fish. Only the oyster larva, an extremely sensitive bioindicator, shows a response to a one $\mathrm{mg} / \mathrm{L}$ concentration (Table 3.21).

\section{Monochloracetic acid}

This haloacetic acid $\left(\mathrm{CH}_{2} \mathrm{ClCOOH}\right)$ is completely ionized at the $\mathrm{pH}$ of natural waters; it is not very volatile but is biodegradable: $73 \%$ is converted into $\mathrm{CO}_{2}$ in 8 to 10 days at $29^{\circ} \mathrm{C}$ (Boetling \& Alexander, 1979). Its toxicity for freshwater organisms is comparable to that of chloroform; toxic effects can be observed at concentrations over one $\mathrm{mg} / \mathrm{L}$ (Table 3.22).

The octanol/water partition coefficient of monoacetic acid is very low $(\log$ Kow $=0.22)$; the lipophilic and bioaccumulation factors of this compound are therefore also very low. Application of the Isnard \& Lambert (1988) relation (log $\mathrm{BCF}=0.80 \mathrm{log}$ (Kow) - 0.52) gives a bioaccumulation factor of 0.45 , indicating that the compound is not bioaccumulated by aquatic organisms.

\section{2,4,6 Trichlorophenol $\left(\mathrm{C}_{6} \mathrm{H}_{3} \mathrm{Cl}_{3} \mathrm{O}\right)$}

This chlorophenol, taken as an example, is slightly volatile; it is photodegradable and biodegradable: $100 \%$ biodegradation in 7 days in do- mestic wastewater, according to Tabak (1981).

In view of the data available (Verschueren 1983), its toxicity can be qualified as moderate :

Goldfish (Carassius auratus), CL50, 24 hours : $10.0 \mathrm{mg} / \mathrm{L}$

Fathead minnow (Pimaphelas promeles), CL50, 96 hours : 0.1 to $1.0 \mathrm{mg} / \mathrm{L}$.

It is moderately bioaccumulated, according to available data. Its bioaccumulation factor can reach 32-63 for the sea mussel, 50 for the green alga Chlorella (Freitag et al., 1982) and 250-316 for freshwater fish (Geyer et al., 1982).

Case study: mass and continuous chlorination of a large recirculating cooling circuit

Since 1996, two 900-MW units of the Dampierre-en-Burly nuclear power station, located on the Loire River in France, have been chlorinated in summer from mid-June to mid-September to eliminate some pathogenic amoebae from the blowdown of the cooling towers. A two-step treatment has been implemented with success.

The first is mass chlorination, by adding sodium hypochlorite as rapidly as possible at $20 \mathrm{mg} / \mathrm{L} F R C$ in the cooling circuit and recirculating for a few hours. This procedure is applied at the beginning of cleaning of the cooling tower and the condensers.

The second step is the maintenance treatment, consisting in the continuous addition of sodium hypochlorite downstream the condensers at a concentration equivalent to 0.27 
Table 3.23. - Levels of oxidants and AOX in the cooling system and at the outlet of the discharge canal at Dampierre power station during the summer 1996 continuous chlorination treatment (Cabanes et al., 1997). FRC: Free residual chlorine.

\begin{tabular}{|c|c|c|c|}
\hline & $\begin{array}{l}\text { Chlorine addition } \\
\left(\mathrm{mg} / \mathrm{L} \text { in } 34 \mathrm{~m}^{3} / \mathrm{s}\right)\end{array}$ & FRC (mg/L) & AOX ( $\mu g / L)$ \\
\hline $\begin{array}{l}\text { July } \\
\text { Unit } 1 \text { cooling water } \\
\text { Unit } 3 \text { cooling water } \\
\text { Power station outlet }\end{array}$ & $\begin{array}{l}0.38 \\
0.36\end{array}$ & $\begin{array}{l}0.49 \\
0.48 \\
0.06\end{array}$ & $\begin{array}{l}390 \\
422 \\
186\end{array}$ \\
\hline $\begin{array}{l}\text { August } \\
\text { Unit } 1 \text { cooling water } \\
\text { Unit } 3 \text { cooling water } \\
\text { Power station outlet }\end{array}$ & $\begin{array}{c}\text { Off-line } \\
0.36 \\
0.27\end{array}$ & $\begin{array}{c}0.48 \\
0.30 \\
0.01-0.02\end{array}$ & $\begin{array}{c}387 \\
470 \\
110-113\end{array}$ \\
\hline $\begin{array}{l}\text { September } \\
\text { Unit } 1 \text { cooling water } \\
\text { Unit } 3 \text { cooling water } \\
\text { Power station outlet }\end{array}$ & $\begin{array}{l}0.27 \\
0.27\end{array}$ & $\begin{array}{l}0.35 \\
0.30 \\
0.02\end{array}$ & $\begin{array}{l}393 \\
543 \\
220\end{array}$ \\
\hline
\end{tabular}

to $0.38 \mathrm{mg} / \mathrm{L}$ into the $34 \mathrm{~m}^{3} / \mathrm{s}$ cooling water closed loop, in order to maintain a FRC concentration of 0.5 or 0.3 $\mathrm{mg} / \mathrm{L}$ (Table 3.23). Due to the high $\mathrm{pH}$ in the cooling water in summer, the non-dissociated fraction of hypochlorous acid was in the range of $3 \%(\mathrm{pH}$ 9) to $24 \%(\mathrm{pH} 8)$ of the FRC. The Dampierre power station comprises 4 units with a common discharge canal, so that the blowdown of the chlorinated units is diluted with the blowdown of the other units in operation.

Very low levels of FRC have been found in the discharge canal during continuous chlorination. The maximum FRC value was measured at the end of the mass chlorination of unit 1 , but the regulation limit was always respected : $0.1 \mathrm{mg} / \mathrm{L} \mathrm{FRC}$ at the outlet of the discharge canal.

Ammonia was at a low level in the cooling water circuit, but the Loire is very rich in phytoplankton during the summer months (> $100 \mu \mathrm{g} / \mathrm{L}$ of chlo- rophyll a), and experimental chlorination curves have shown the formation of combined chlorine, most probably corresponding to organic chloramines. Combined residual chlorine measured by colorimetric DPD was in the range of 0.58 to $0.90 \mathrm{mg} / \mathrm{L}$ in the cooling water and 0.13 to $0.21 \mathrm{mg} / \mathrm{L}$ at the outlet of the discharge canal.

The mass chlorination process generates large amounts of AOX at the outlet of the discharge canal (193 $\mu \mathrm{g} / \mathrm{L}$ for unit 3 to $690 \mu \mathrm{g} / \mathrm{L}$ for unit 1 ), but chloroform remains at $20 \mu \mathrm{g} / \mathrm{L}$ due to volatilization in the cooling tower.

During continuous chlorination, chloroform stays at a low level : 5.1 to $9.6 \mu \mathrm{g} / \mathrm{L}$ for $F R C=0.5 \mathrm{mg} / \mathrm{L}$ and 2.4 to $3.8 \mu \mathrm{g} / \mathrm{L}$ for $F R C=0.3 \mathrm{mg} / \mathrm{L}$. Bromodichloromethane varied between 0.2 and $0.6 \mathrm{mg} / \mathrm{L}$, and dibromochloromethane remained below $0.2 \mu \mathrm{g} / \mathrm{L}$. Thus, THMs represent no more than $5 \%$ of the $\mathrm{AOX}$ in the discharge canal, where concentrations ranged from 110 to $220 \mu \mathrm{g} / \mathrm{L}$. 
Table 3.24. - EOX concentrations measured in fish flesh upstream and downstream of the Dampierre en Burly power station, after one month of continuous chlorination in July 1996. Measurements made by F. Hayer at Université de Metz.

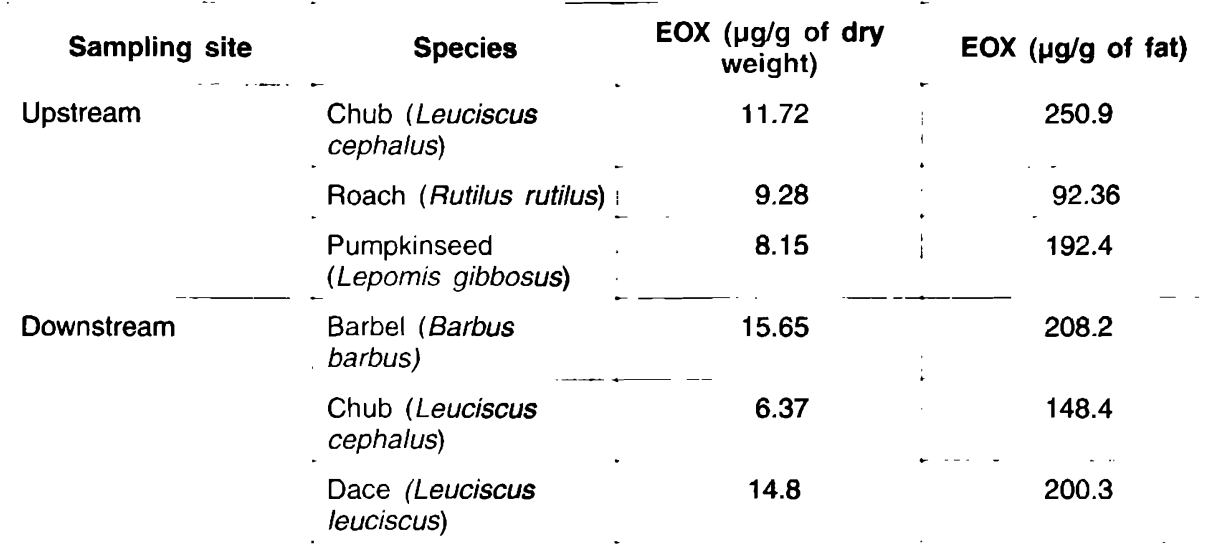

Toxicity of the discharge water was monitored by using Daphnia and Microtox standardized bioassays; there was no acute toxicity throughout the chlorination treatment. In the ecological monitoring program at the Dampierre power station, samples of plankton, periphyton and macroinvertebrates are collected and fish are sampled by electrofishing up- and downstream the power station. No modification in these ecological compartments can be attributed to the continuous chlorination.

A temporary drop in periphyton algal diversity was observed following mass chlorination; it is most probably due to the addition of organic matters from cleaning of the cooling tower.

EOX dosages were performed on the flesh of fish caught up- and downstream of the plant after one month of continuous chlorination. The two zones of the river are separated by a sill which prevents caught fish from returning upstream. The same EOX levels were measured upstream and downstream (Table 3.24).

\section{CBPs and drinking water}

When organohalogenated compounds are added to freshwater used to produce drinking water, a sanitation risk must be considered. WHO (1993b) guidelines and regulation limits exist on the main CBPs identified in chlorinated natural waters (Table 3.25). To be able to continue to use surface water for drinking purposes, it is advisable to reduce CBP loads as much as possible; production of drinking water therefore limits the potential for use of chlorination as an antifouling treatment in rivers.

\section{Chlorination at marine sites}

In seawater, chlorination produces primarily oxidizing and non-oxidizing brominated compounds. 
Table 3.25. - Guideline values and regulation limits for the principal disinfectants used to produce drinking water.

\begin{tabular}{|c|c|c|c|c|c|}
\hline Source & $\begin{array}{l}\text { Chlorine and } \\
\text { derived oxidants } \\
(\mathrm{mg} / \mathrm{L})\end{array}$ & $\begin{array}{l}\text { Chlorine } \\
\text { dioxide } \\
\mu g / L\end{array}$ & $\begin{array}{c}\text { Chlorites } \\
\mu \mathrm{g} / \mathrm{L}\end{array}$ & $\begin{array}{c}\text { Organohalogens } \\
\mu \mathrm{g} / \mathrm{L}\end{array}$ & $\begin{array}{c}\text { Bromate } \\
\mu g / L\end{array}$ \\
\hline $\begin{array}{l}\text { WHO } \\
\text { guidelines } \\
1993 b\end{array}$ & $\begin{array}{c}\text { Free } \\
\text { chlorine : } \mathbf{5} \\
\text { Chloramines : } \mathbf{3}\end{array}$ & Absence & 200 & $\begin{array}{c}\mathrm{CHCl}_{3}: 200 \\
\mathrm{CHCl}_{2} \mathrm{Br}^{2}: 60 \\
\mathrm{CHClBr}_{2}: 100 \\
\mathrm{CHBr}_{3}: 100 \\
\mathrm{DCAN}: 90 \\
\text { DBAN }: 100 \\
\text { TCAN : } 1 \\
\text { BCAN : Absence } \\
\text { DCAA : } 50 \\
\text { TCAA : 100 } \\
\text { MAA : Absence } \\
\text { 246TCP : } 200\end{array}$ & 25 \\
\hline $\begin{array}{l}\text { European } \\
\text { Directive } \\
\text { EEC } 1998\end{array}$ & & & & $\begin{array}{l}\mathrm{CHCl}_{3}: 40 \\
\mathrm{CHCl}_{2} \mathrm{Br}: 15 \\
\mathrm{THMs}: 100\end{array}$ & 10 \\
\hline US EPA (1) & Free Chlorine : 4 & 800 & 1000 & THMs : 80 & 10 \\
\hline & Chloramines : 4 & & & 5 HAA : 60 & \\
\hline
\end{tabular}

(1) Richardson, 1997. Maximum Residual Disinfectant Level.

DCAN : dichloroacetonitrile - DBAN : dibromoacetonitrile - TCAN : trichloroacetonitrile BCAN : bromochloroacetonitrile - HAA : haloacetic acids - MAA : monochloracetic acid - DCAA : Dichloracetic acid - TCAA : Trichloracetic acid.

No chlorate limit in the WHO guidelines.

There is a considerable decrease in residual oxidants in thermal plant cooling systems, as seen from the example in Figure 3.19: an hypochlorite injection at $0.8 \mathrm{mg} / \mathrm{L}$ gives a TRO of $0.3 \mathrm{mg} / \mathrm{L}$ at the condenser; the decrease along the outlet pipe is then sufficient to bring TRO to $0.1 \mathrm{mg} / \mathrm{L}$ at the point of discharge into the sea.

On-site measurements at power station sites in Gravelines, Penly and Heysham, (Khalanski, 1985, Jenner et al., 1997) have shown that the residual chlorine concentration decreases very rapidly in the discharge plumes due to dilution and chemical consumption of oxidants. Davis \& Coughlan (1983) proposed a simple model to predict the residual oxidant concentration in the cooling circuits and in the plume.

Extensive field studies have been conducted at coastal power stations in the UK and in France (Davis \& Coughlan, 1983; Khalanski, 1993) to assess the impact of seawater chlorination on the marine littoral system. The major changes concern the plankton passing through the cooling circuit during chlorination: oxidants 


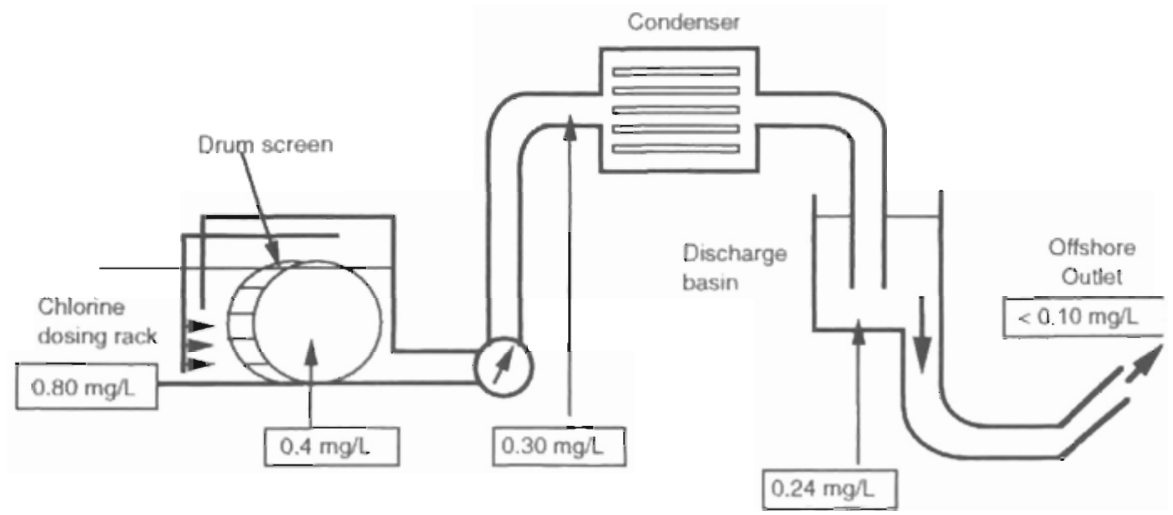

Fig. 3.19. - Decay of TRO at the Penly nuclear power station for a chlorine dosage of $0.8 \mathrm{mg} / \mathrm{L}$.

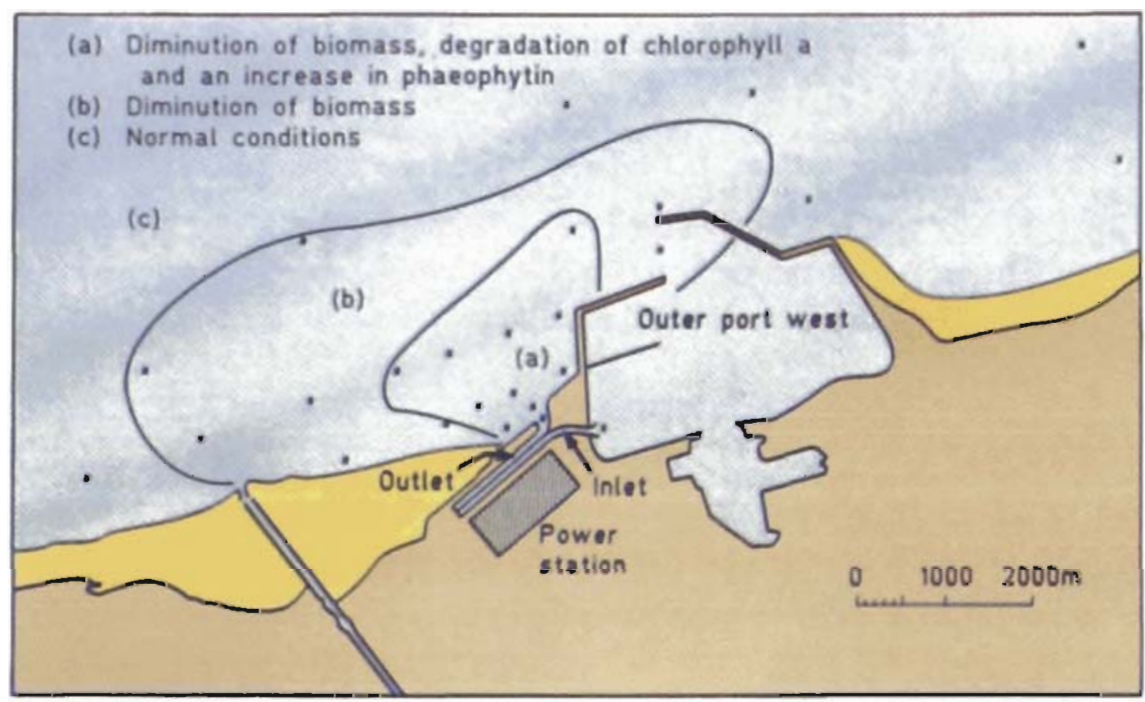

Fig. 3.20. - Maximum extent of the discharge plume at Gravelines over one tidal cycle showing the effect on phytoplankton biomass. Cooling water flow $160 \mathrm{~m}^{3} / \mathrm{s}$, chlorination $1.0 \mathrm{mg} / \mathrm{L}$ injected.

are responsible for decreases in the bacteria and phytoplankton biomass and production, but the disappearance of residual oxidants leads to recovery of plankton productivity. A return to normal conditions is observed as soon as one moves away from the near vicinity of the release (Fig. 3.20).

Plume studies conducted at the same time showed that the bromoform concentration decreased along the plume with a non-linear reduction in concentration from $14 \mathrm{mg} / \mathrm{L}$ at the 


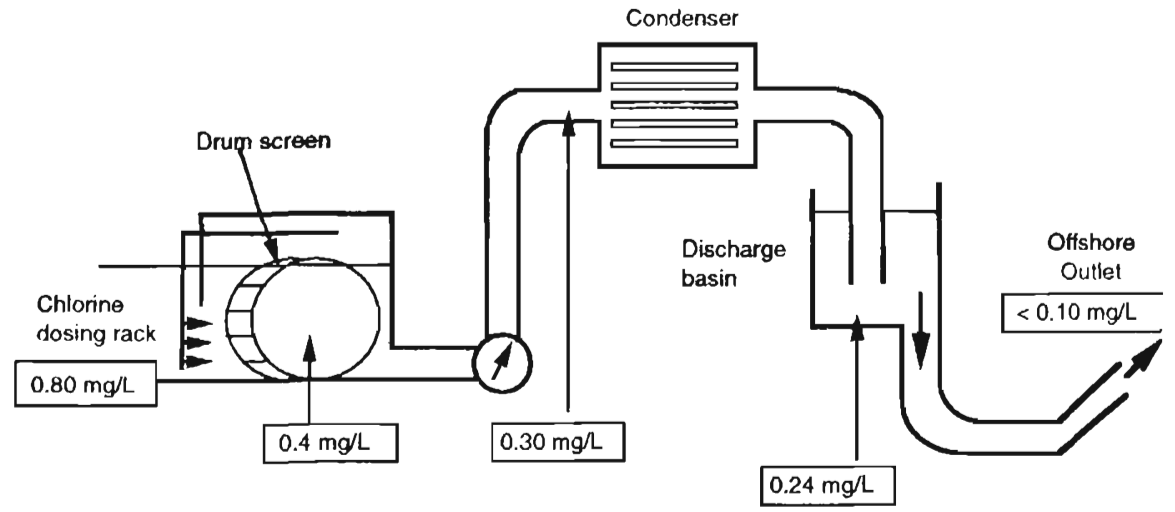

Fig. 3.19. - Decay of TRO at the Penly nuclear power station for a chlorine dosage of $0.8 \mathrm{mg} / \mathrm{L}$.

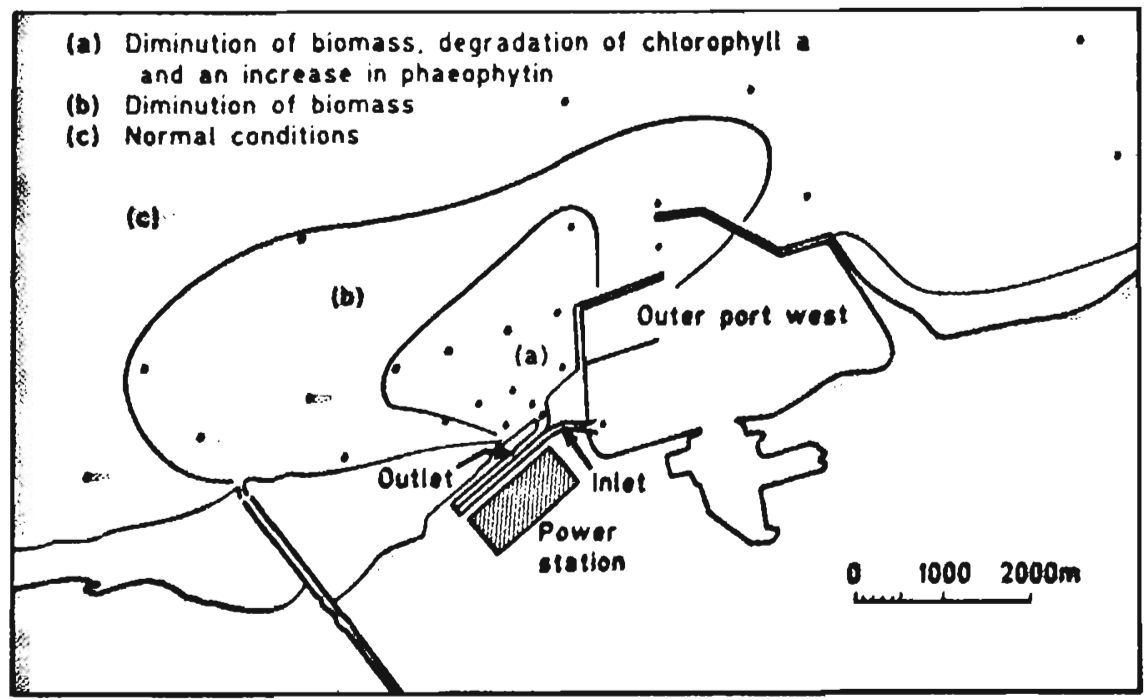

Fig. 3.20. - Maximum extent of the discharge plume at Gravelines over one tidal cycle showing the effect on phytoplankton biomass. Cooling water flow $160 \mathrm{~m}^{3} / \mathrm{s}$, chlorination $1.0 \mathrm{mg} / \mathrm{L}$ injected.

are responsible for decreases in the bacteria and phytoplankton biomass and production, but the disappearance of residual oxidants leads to recovery of plankton productivity. A return to normal conditions is observed as soon as one moves away from the near vicinity of the release (Fig. 3.20).

Plume studies conducted at the same time showed that the bromoform concentration decreased along the plume with a non-linear reduction in concentration from $14 \mathrm{mg} / \mathrm{L}$ at the 


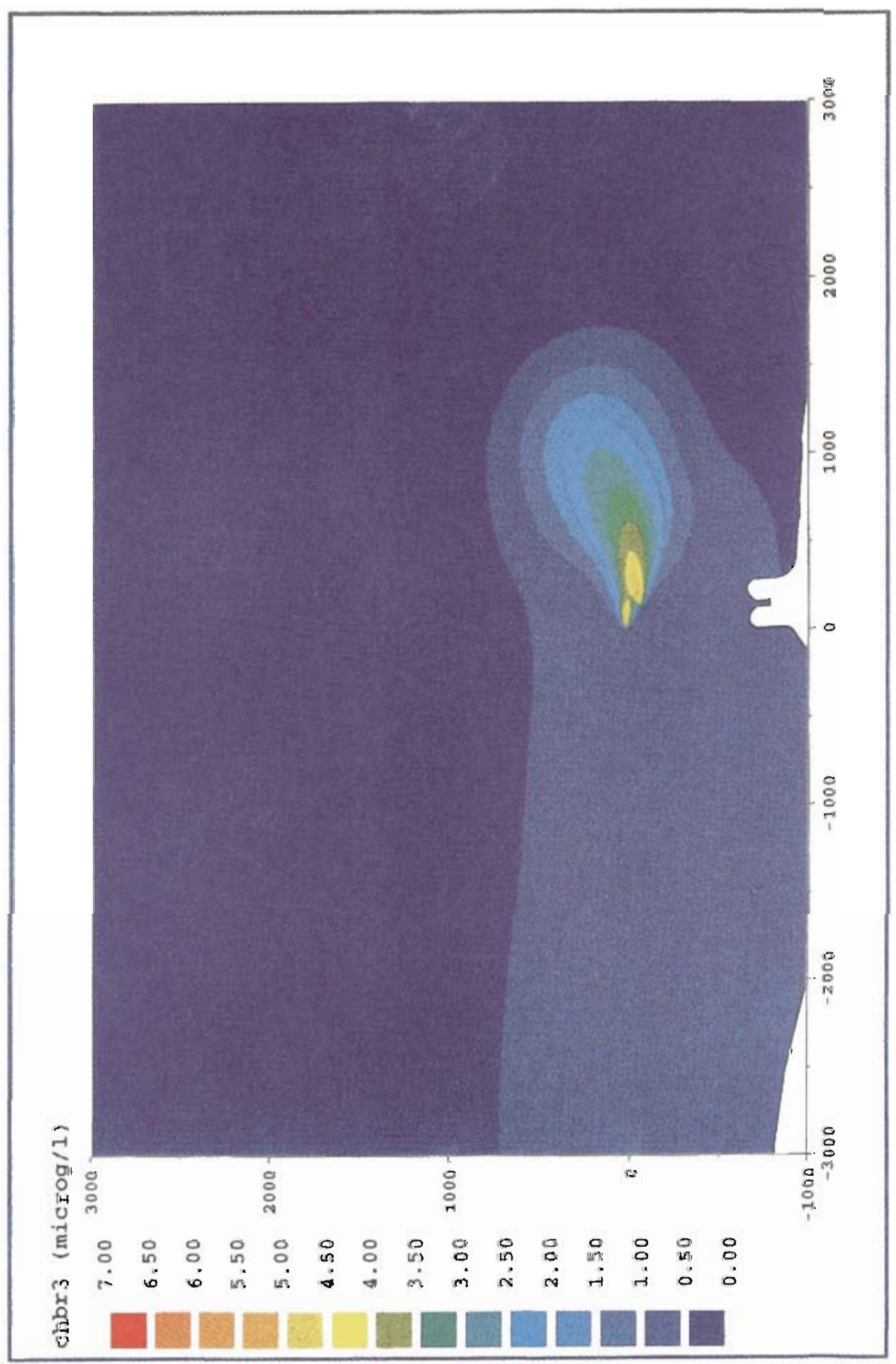

Fig. 3.21. - Dilution of bromoform in the discharge plume of the Penly nuclear power station, located on the English Channel. (Marcos \& Gailhard, 1994). 
discharge to approximately $1.0 \mathrm{mg} / \mathrm{L}$ $2 \mathrm{~km}$ from the discharge at Heysham and Sizewell (Jenner et al., 1997).

Measurements of THMs have been taken at the Gravelines power station with a flow of $160 \mathrm{~m}^{3} / \mathrm{s}$, chlorinated to $1 \mathrm{mg} / \mathrm{L}$ (Khalanski \& Lutz, 1987). The bromoform concentration falls rapidly to about $1 \mu \mathrm{g} / \mathrm{L}$ in the plume. Similar measurements at Penly showed three zones in the vicinity of the offshore outlet :

$100-200 \mathrm{~m}$ from the discharge

$$
1.66 \pm 0.40 \mu \mathrm{g} / \mathrm{L}
$$

200-1500 $\mathrm{m}$ from the discharge

$$
0.44 \pm 0.13 \mu \mathrm{g} / \mathrm{L}
$$

$1500-15 \mathrm{~km}$ from the discharge

$$
0.26 \pm 0.10 \mu \mathrm{g} / \mathrm{L}
$$

The dilution of bromoform in the discharge plume of the Penly power station was modeled using the TELEMAC 3D code (Marcos \& Gailhard, 1994) (Fig. 3.21) showing that the concentration level is less than $1 \mu \mathrm{g} / \mathrm{L}$ at that site.

These results may be compared with published data on the toxicity of chlorination by-products in a marine environment (Table 3.26). The evidence available up to 1995 suggests that the concentrations of THM in the discharges from a wide variety of power stations in Europe are on the order of $10^{-3}$ times the EC50 and LC50 data from published results. This implies that in the marine environment, there is no expected acute toxic effect from these compounds.

Until recently, it was considered that natural sources of halocarbons were extremely rare and the presence of halocarbons in the environment indicated anthropogenic contamination. It is now recognized that many organisms, particularly in the sea, produce halocarbons which closely resemble those found in chlorinated water (e.g. THMs, halophenols and halo-aromatic acids) (Gribble, 1994). Natural production of AOX in the Rhine is approximately $50 \%$ of the total (Hoekstra \& De Leer, 1994) and Harper (1994) estimates the natural global air-ocean flux of bromoform at 1 to $2 \times 10^{6}$ tons annually. This indicates not only that some organisms are capable of thriving in the presence of these compounds but also that if there are natural sources, there must also be natural sinks.

\subsubsection{Chloramine}

A number of power stations in Belgium (Drogenbos, Seraing and Tihange) suffer from fouling by bryozoans, Plumatella sp, very abondants in the cold basins of the towers or in some water chambers. To eliminate Molluscs and small colonies of Bryozoans, the procedure used in Belgian power stations is a periodic treatment to kill the bio-fouling from the main settlement peak to the end of the developping period in autumn. The chloramine dosage at a concentration $\geq 5 \mathrm{mg} / \mathrm{L}$ is applied twice a weeks (about 10 times a month), for 3 to 4 hours. Monochloramine kills bryozoans for 3 hours at $6.0 \mathrm{mg} / \mathrm{L}$ (Duvivier \& Vanmaele, 1995), but it is also effective against zebra mussels. 
Table 3.26. - Summary of selected data on THM toxicity to marine organisms.

\begin{tabular}{|c|c|c|c|c|}
\hline Compound & Marine groups & Toxicity index & $\begin{array}{c}\text { Concentration } \\
\mathrm{mg} / \mathrm{L}\end{array}$ & Reference \\
\hline \multirow{4}{*}{ Bromoform } & $\begin{array}{l}\text { Diatoms, } \\
\text { Flagellates }\end{array}$ & $\mathrm{EC}_{50}, 7$ days & $>32$ & $\begin{array}{c}\text { Erikson \& } \\
\text { Freeman, } 1978\end{array}$ \\
\hline & Molluscs & $L_{50}, 96$ hours & $40-140$ & \multirow{3}{*}{$\begin{array}{c}\text { Gibson et al., } \\
1980\end{array}$} \\
\hline & Crustaceans & LC 50,96 hours & 26 & \\
\hline & Fish & LC 50,96 hours & 12 & \\
\hline $\begin{array}{l}\text { Bromodichloro- } \\
\text { methane }\end{array}$ & Ciliate & $\mathrm{EC}_{50}, 24$ hours & 240 & $\begin{array}{c}\text { Yoshioka et al., } \\
1985\end{array}$ \\
\hline \multirow{4}{*}{ Chloroform } & $\begin{array}{l}\text { Diatoms, } \\
\text { Flagellates }\end{array}$ & $\mathrm{EC}_{50}, 7$ days & $>32$ & $\begin{array}{c}\text { Erikson \& } \\
\text { Freeman, } 1978\end{array}$ \\
\hline & Molluscs & $L_{50}, 48$ hours & $0.15-1$ & $\begin{array}{c}\text { Stewart et al., } \\
1979\end{array}$ \\
\hline & Crustaceans & $\mathrm{LC}_{100}, 24$ hours & $464-800$ & $\begin{array}{c}\text { Okubo \& Okubo } \\
1962\end{array}$ \\
\hline & Fish & $L^{2} C_{50}, 96$ hours & 28 & Madeley, 1973 \\
\hline
\end{tabular}

At Drogenbos and Seraing (450 MW each) the method currently used to control and kill this organism is chloramination. Monochloramine is produced on-site by means of mixing solutions of sodium hypochorite and ammonia chloride $\left(\mathrm{NH}_{4} \mathrm{Cl}\right)$. The optimum mass ratio chlorine/nitrogen must be $5 / 1$ to produce monochloramine (Duvivier, 1993).

\subsubsection{Chlorine dioxide}

Chlorine dioxide is a potential alternative to chlorination because of its effectiveness as a disinfectant (Benarde et al., 1965), for control of microbial slimes in condenser tubes of inland power stations (Rauh 1979, Mayack et al., 1984) and because there is less production of organoha- logenated by-products (Ben Amor et al., 1988, Lykins \& Griese, 1986). Although the main uses of chlorine dioxide are pulp and paper bleaching, food processing and drinking water and wastewater disinfection, the efficacy of chlorine dioxide has been tested on-site on large marine cooling water systems in Italy and Spain.

\subsubsection{Production of chlorine dioxide}

Chlorine dioxide gas cannot be condensed and liquefied as chlorine because of the risk of explosive disintegration. For this reason, it is produced on-site from sodium chlorite $\mathrm{NaClO}_{2}$ in two principal ways (Schneider 1997):

- chlorite oxidation by chlorine gas. 
$2 \mathrm{NaClO} \mathrm{Cl}_{2}+\mathrm{Cl}_{2} \rightarrow 2 \mathrm{ClO}_{2}$ $+2 \mathrm{NaCl}$

This reaction requires an excess of chlorine to optimize the chlorine dioxide production yield.

- acidification of chlorine.

$$
\begin{gathered}
5 \mathrm{Na} \mathrm{ClO}_{2}+4 \mathrm{HCl} \rightarrow 4 \mathrm{ClO}_{2} \\
+5 \mathrm{NaCl}+2 \mathrm{H}_{2} \mathrm{O}
\end{gathered}
$$

This is the most common industrial process used for cooling water treatments. To maximize the production yield of chlorine dioxide, up to $95 \%$, and to reduce resulting by-products, a large excess of $\mathrm{HCl}(>250 \%)$ is required.

According to Schneider (1997): "There is no such thing as stabilized chlorine dioxide in a canister! These claims are simply unfounded. Our own experiments and those of external institutes have shown that these preparations are invariably diluted sodium chlorite solutions."

Safety. Chlorine dioxide solutions are explosive above a concentration of $30 \mathrm{~g} / \mathrm{L}$; this means that the concentration must be below $30 \mathrm{~g} / \mathrm{L}$ at all points of the production system. It is also necessary to avoid any accidental mixing of the reagents (chlorite and acid), which can explode. In the gaseous state, they can explode at air concentrations above $10 \%$ in the presence of a flame (Masschelein, 1979). Chlorine dioxide generators are therefore especially designed to eliminate this risk. Acute exposure of workers results in irritation of eyes, nose, throat and lungs. For people working in chorine dioxide production areas, the short-term exposure limit is $0.9 \mathrm{mg} / \mathrm{m}^{3}$ (Gordon \& Bubnis, 1997).

\subsubsection{Chemistry of chlorine dioxide in aqueous solution}

Chlorine dioxide is a gas at ambient temperature; its ebullition point is $11^{\circ} \mathrm{C}$. It is very soluble in water and is decomposed by light. As mentioned above, it is very unstable and explosion must be avoided. It is a powerful oxidant with the following global reduction reaction involving 5 electrons (Belluati et al., 1997) :

$$
\mathrm{ClO}_{2}+4 \mathrm{H}^{+}+5 \mathrm{e}^{-} \rightarrow \mathrm{Cl}^{-}+2 \mathrm{H}_{2} \mathrm{O}
$$

Contrary to free chlorine, the oxidizing power of chlorine dioxide does not depend on the $\mathrm{pH}$ in a wide $\mathrm{pH}$ range (5.0 to 9.5 ).

In aqueous solutions, chlorine dioxide does not react with bromide ions as do other oxidants: ozone, chlorine, hypochlorite. This means that it does not produce free bromine in seawater.

It does not react with ammonia to form chloramines and does not chlorinate organic compounds; as a consequence, it does not produce chlorophenols, THMs and, in general, AOX.

Chlorine dioxide oxidizes metals in reduced forms $\left(\mathrm{Fe}^{++}, \mathrm{Mn}^{++}\right)$, nitrites $\left(\mathrm{NO}_{2}^{-}\right)$and sulfites $\left(\mathrm{SO}_{2}^{-}\right)$and dissolved organic matter (Dore 1989). This process can cause a very high demand in polluted or eutrophicated natural waters. It can also produce deposits of $\mathrm{Fe}(\mathrm{OH})_{3}$ and $\mathrm{MnO}_{2}$ in heat exchangers. 
Inorganic by-products - chlorite ions $\left(\mathrm{ClO}_{2}^{-}\right)$and chlorate ions $\left(\mathrm{ClO}_{3}^{-}\right)$ are produced during the generation phase (Lefebvre \& Deguin, 1997), but chlorite is also formed by the oxidation process itself :

$$
\begin{gathered}
\mathrm{ClO}_{2}+\text { organics } \rightarrow \text { oxidation } \\
\text { products }+\mathrm{ClO}_{2}^{-}
\end{gathered}
$$

The chlorite concentration in treated water depends on the demand of the water; it will be $>1 \mathrm{mg} / \mathrm{L}$ if the $\mathrm{ClO}_{2}$ demand is higher than $1 \mathrm{mg} / \mathrm{L}$ (Gordon \& Bubnis, 1997).

At $\mathrm{pH} 7$, chlorine dioxide solutions are stable but hydrolysis occurs at basic $\mathrm{pH}$ to form chlorite and chlorate :

$$
\begin{gathered}
2 \mathrm{ClO}_{2}+2 \mathrm{OH}^{-} \rightarrow \mathrm{ClO}_{2}^{-}+\mathrm{ClO}_{3}^{-}+ \\
\mathrm{H}_{2} \mathrm{O}
\end{gathered}
$$

Photochemical reactions result in formation of chlorate ions.

Some organohalogenated compounds can also be formed by indirect chlorination due to the hypochlorous acid produced by chlorine dioxide reactions on different chemical structures such as phenolic compounds (Doré, 1989).

Finally, the U.S. E.P.A. has identified bromates and aldhehydes as byproducts which can be formed by chlorine dioxide. The aldehydes include the propanal to decanal series, glyoxal, methyl glyoxal, and benzaldehyde (Richardson, 1997).

Several analytical methods have been developed to measure chlorine dioxide and its inorganic by-products. The amperometric method (Standard methods 1992) determines concentrations of $\mathrm{ClO}_{2}, \mathrm{ClO}_{2}^{-}$and $\mathrm{ClO}_{3}^{-}$; this method by difference is, however, subject to major errors, in particular for chlorates (Gordon \& Bubnis, 1997). On-line amperometric systems exist for continuous monitoring of the chlorine dioxide level with a detection threshold on seawater as low as 10 $\mu \mathrm{g} / \mathrm{L}$. ENEL has developed a continuous potentiometric method with the same detection threshold of $10 \mu \mathrm{g} / \mathrm{L}$.

Among the colorimetric methods (lissamine green $B$, chlorophenol red, amaranth), amaranth has the best specificity and the lowest quantification limit, at $20 \mu \mathrm{g} / \mathrm{L}$ (Mantisi et al., 1997).

Ion chromatography is used to measure chlorites and chlorates at the $10 \mu \mathrm{g} / \mathrm{L}$ level (Gordon \& Bubnis, 1997).

\subsubsection{Experimental data on efficacy of chlorine dioxide on biofouling}

To eliminate the micro-biofouling and filamentous algae which develop on the packing of cooling towers, experiments performed at a pilot plant fed with Seine river water have shown that a residual dose of $1.5 \mathrm{mg} / \mathrm{L}$ chlorine dioxide for two hours is required. At the $0.3 \mathrm{mg} / \mathrm{L}$ concentration, the exposure time required is a few days (Merle \& Montanat, 1980).

With respect to freshwater systems, laboratory tests have been conducted on zebra mussels Dreissena polymorpha (Montanat et al., 1980; Van Benschoten et al., 1993; Khalanski, 1993; Matissoff et al., 1996). 
An initial series of tests in Seine river water bore on the effect of single injections at high concentrations ranging from 10 to $40 \mathrm{mg} / \mathrm{L}$ (Montanat et al., 1980). It was observed that brief exposure (13 minutes at $10 \mathrm{mg} / \mathrm{L}$ or 3.2 minutes at $40 \mathrm{mg} / \mathrm{L}$ ) kills $50 \%$ of adult mussels. On the other hand, there is no significant mortality for 6 hours of exposure at $2 \mathrm{mg} / \mathrm{L}$ (Table 3.27).

On Lake Erie mussels (Matissoff et al., 1996), intermittent injections of 1 $\mathrm{mg} / \mathrm{L}$ for 30 minutes a day for 28 days are not effective; mortality is significant at $5 \mathrm{mg} / \mathrm{L}$ and it takes only 4 days of exposure at $40 \mathrm{mg} / \mathrm{L}$ to kill $95 \%$ of adult mussels (Table 3.28 ).

Table 3.27. - Mortality of adult zebra mussels exposed to single shocks of chlorine dioxide. Experiments on river Seine and Moselle water at temperature of $15^{\circ} \mathrm{C}$ to $20^{\circ} \mathrm{C}$. ns : non significant data.

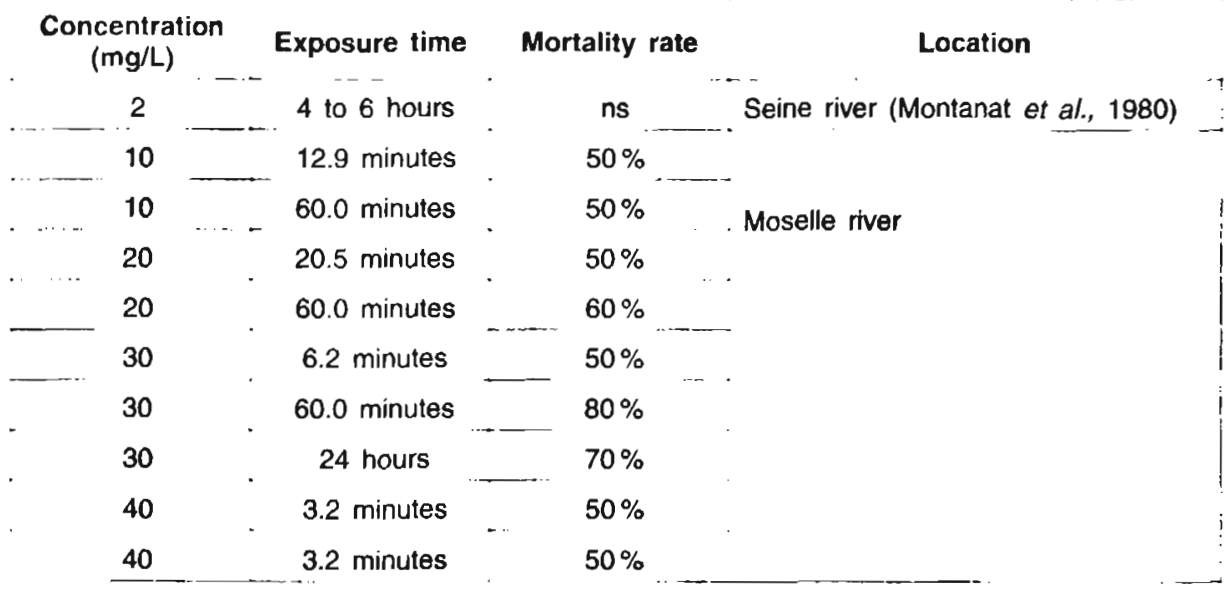

Table 3.28. - Mortality of adult zebra mussels exposed to intermittent chlorine dioxide doses in Lake Erie water at temperatures of $13^{\circ} \mathrm{C}$ to $20^{\circ} \mathrm{C}$ (Matisoff et al., 1996).

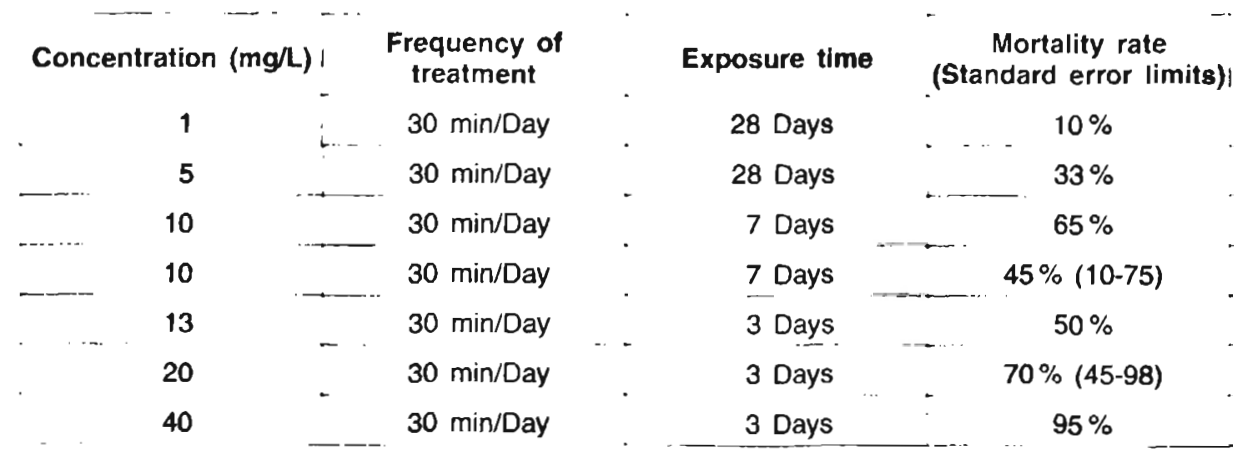


These findings show that chlorine dioxide shocks in relatively low concentrations, whether single or repeated over several days, kill between $50 \%$ and $90 \%$ of adult zebra mussels. Chlorine dioxide is therefore more effective than chlorine in intermittent treatments at high concentrations.
Continuous treatment with chlorine dioxide kills adult zebra mussels in 8 days at a residual of $0.2 \mathrm{mg} / \mathrm{L}$ (Table 3.29). The lethal time ( $\left.L T_{100}\right)$, the time required to kill $100 \%$ of the exposed mussels, is given by the following relation (Fig. 3.22) :

$$
\begin{gathered}
\mathrm{LT}_{100}=4.47+3.79^{*} \mathrm{LOG}\left(\mathrm{ClO}_{2}\right) \\
\mathrm{r}^{2}=0.94
\end{gathered}
$$

Table 3.29. - Mortality of adult zebra mussels exposed to continuous chlorine dioxide

\begin{tabular}{|c|c|c|c|c|}
\hline $\begin{array}{c}\text { Concentration } \\
(\mathrm{mg} / \mathrm{L})\end{array}$ & Exposure time & Mortality rate & $\begin{array}{c}\text { Water } \\
\text { Temperature }\end{array}$ & Reference \\
\hline 0.15 & 7 days & $100 \%$ & $15^{\circ} \mathrm{C}$ & Montanat et al., 1980 \\
\hline 0.20 & 8 days & $100 \%$ & $20-25^{\circ} \mathrm{C}$ & Khalanski, 1993 \\
\hline 0.25 & 6 days & $45 \pm 20 \%$ & & \\
\hline 0.50 & 6 days & $70 \pm 10 \%$ & & 1 \\
\hline 1.00 & 2 days & $60 \pm 7 \%$ & $13^{\circ} \mathrm{C}$ to $20^{\circ} \mathrm{C}$ & Matissoff et al., 1996 \\
\hline 1.00 & 3 days & $90 \pm 10 \%$ & & $i$ \\
\hline 1.00 & 4 days & $99 \pm 10 \%$ & & i \\
\hline 5.00 & 2 days & $100 \%$ & & ! \\
\hline
\end{tabular}
doses.

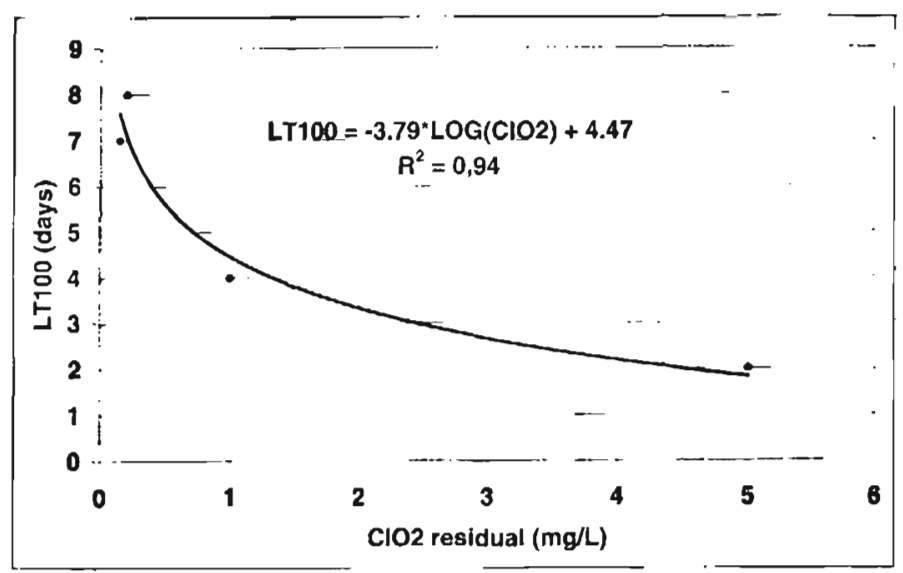

Fig. 3.22. - Lethal time for $100 \%$ of adult zebra mussels exposed to chlorine dioxide. Data from Table 3.29. 
ENEL has tested the efficacy of chlorine dioxide on seawater in model culverts. No macro-biofouling development was found on concrete plates at residual concentrations of 0.1 to $0.2 \mathrm{mg} / \mathrm{L}$ and after a month of continuous treatment at $0.1 \mathrm{mg} / \mathrm{L}$, there was no microfouling growth on condenser tubes (Ambrogi, 1997).

Experiments on the Mediterranean hydroid Laomedea flexuosa exposed to chlorine dioxide by ENEL (Geraci et al., 1993) have given the following results :

- no significant reduction of hydroids at $0.05 \mathrm{mg} / \mathrm{L}$ for 96 hours' exposure,

- significant reduction at 0.1 to $0.2 \mathrm{mg} / \mathrm{L}$ for 48 hours' exposure,

- elimination of hydroids at 0.1 to $0.2 \mathrm{mg} / \mathrm{L}$ for 96 hours' exposure.

On the Mediterranean coast of $\mathrm{Ca}$ talonia in Spain, experiments have been conducted on the marine mus- sel Mytilus galloprovincialis at the Vandellos II nuclear power station (Bielza et al., in Belluati et al., 1997). A comparison between the efficacy of chlorine and chlorine dioxide treatments in killing the marine mussel has shown that chlorine dioxide at a residual of $0.2 \mathrm{mg} / \mathrm{L}$ kills the mussels more rapidly than chlorine at a residual of $1.1 . \mathrm{mg} / \mathrm{L}$ (Table 3.30). Specific experiments shown that long-term semi-continuous additions of chlorine dioxide at a residual of $0.2 \mathrm{mg} / \mathrm{L}, 1$ hour on, 2 hours off, is as efficient as continuous treatment. This semi-continuous procedure is also efficient with hypochlorite at a residual of 1.0 to 1.2 $\mathrm{mg} / \mathrm{L}$ (Castellnou, pers. com).

As regards other macro-biofouling, intermittent treatment with chorine dioxide can significantly reduce biological development when the oxidant is added for 8 hours per day (Table 3.31).

Table 3.30. - Exposure time to reach $50 \%, 80 \%$ and $95 \%$ mortality on three sets of adult Mediterranean mussels Mytilus galloprovincialis, having different shell size when exposed continuously to chlorine dioxide $(0.2 \mathrm{mg} / \mathrm{L}$ residual) or to hypochlorite $(1.1 \mathrm{mg} / \mathrm{L}$ residual). Data from a figure in Belluati et al., 1997.

\begin{tabular}{|c|c|c|c|}
\hline & Shell length & $\begin{array}{c}\text { Chlorine dioxide } \\
0.2 \mathrm{mg} / \mathrm{L}\end{array}$ & $\begin{array}{l}\text { Chlorine } \\
1.1 \mathrm{mg} / \mathrm{L}\end{array}$ \\
\hline & Small & 15 days & $>26$ days \\
\hline \multirow[t]{3}{*}{$50 \%$ mortality } & Medium & 10 days & 15 days \\
\hline & Large & 8 days & 13 days \\
\hline & Small & 20 days & $>28$ days \\
\hline \multirow[t]{3}{*}{$80 \%$ mortality } & Medium & 14 days & 28 days \\
\hline & Large & 14 days & 28 days \\
\hline & Small & 26 days & $>28$ days \\
\hline \multirow[t]{2}{*}{$95 \%$ mortality } & Medium & 20 days & $>28$ days \\
\hline & Large & 20 days & $>28$ days \\
\hline
\end{tabular}


Table 3.31. - Efficacy of intermittent chlorine dioxide treatments on macro-biofouling growth at Vandellos, Mediterranean coast of Catalonia in Spain. UNESA data.

\begin{tabular}{l}
$\begin{array}{l}\text { Chlorine dloxide treatment } \\
\text { control (0) }\end{array}$ \\
\hline 4 hours/day \\
\hline 6 hours/day \\
\hline 8 hours/day \\
\hline \\
3.7.3.4 Chlorine dioxide testing \\
at industrial sites
\end{tabular}

An on-site experiment was conducted for 4 months on a recirculating cooling water system at a chemical plant located at Höcht on the Main river in Germany (Wasel-Nielen \& Baresel, 1997). Chlorine dioxide was added to the circulating water $(6,000$ $\mathrm{m}^{3} / \mathrm{h}$ ) twice a day for at least 2 hours to reach the concentration peak of 0.2 $\mathrm{mg} / \mathrm{L}$. This target concentration was difficult to achieve even after 8 hours of treatment because of the chlorine dioxide demand in the cooling water, which was high and variable. In this experiment, high levels of chlorine dioxide were measured: 1.5 to $5.0 \mathrm{mg} / \mathrm{L}$. Nevertheless, this treatment reduced the AOX production in comparison to that produced by chlorination.

As for the cooling circuits of power stations fed with seawater, large-scale experiments have been conducted in recent years in Italy and in Spain.

Brindisi Nord power station, operated by ENEL on the Adriatic Sea

Hydroids
Algae
Tubeworms
Hydroids
Algae
Tubeworms
Hydroids
Algae
Tubeworms
Hydroids

Magnitude of fouling
Large deposits
Moderate deposits
Moderate deposits
Some deposits

(4,320-MW units) (Ambrogi, 1997). The cooling water intake is located in a sheltered basin of the Brindisi harbour where municipal sewage discharges high amounts of organic matter. Biofouling is mainly composed of calcareous tube serpulids (Spirorbis, Hydroides elegans), hydroids, mussels and barnacles. The biomass, measured on $20 \times 30 \mathrm{~cm}$ panels, reaches a maximum wet weight of $160 \mathrm{~g}$ for 3 months. The condenser tubes are not equipped with a sponge-ball cleaning system. Chlorine dioxide produced on-site by a chlorite/ $\mathrm{HCl}$ generator was continuously added to the cooling water from 1989 to 1992. In 1989, the dosage was $0.22 \mathrm{mg} / \mathrm{L}$; since 1990 , it has been reduced to $0.18 \mathrm{mg} / \mathrm{L} \mathrm{du}$ ring the summer season and 0.07 $\mathrm{mg} / \mathrm{L}$ in winter from November to May. This variation of dosage allows for the seasonal variation in chlorine dioxide demand. Control panels placed inside the condenser box were invariably clean of both macrofouling and slime.

At the end of the outlet canal, amperometric measurements of chlorine 
dioxide showed very low residuals $(\leq 0.024 \mathrm{mg} / \mathrm{L})$; outside the canal, residuals were below the quantification limit of $0.010 \mathrm{mg} / \mathrm{L}$. Chlorite was always present in both the canal and the harbour water.

Leghorn - Livorno power station operated by ENEL on the Mediterranean (2,160-MW units). Short-term injection of chlorine dioxide at $\leq 0.2$ $\mathrm{mg} / \mathrm{L}$ was performed for 20 days in 1995 and 1996 to eliminate Serpulid growth in the circuit downstream of the point of injection of hypochlorite.

Vandellos II nuclear power station, operated by UNESA on the Mediterranean coast of Catalonia in Spain $(1,000 \mathrm{MW})$. A program was conducted to compare the efficacy of chlorination and chlorine dioxide and the production of THMs with these two methods.

Half the cooling water flow (25 $\mathrm{m}^{3} / \mathrm{s}$ ) was treated with chlorine dioxide produced by a chlorite/ $\mathrm{HCl}$ generator; the remainder was treated by electrochlorination. At Vandellos, the water is treated 3 to 4 months a year, depending on biofouling monitoring data. The following dosages were adopted :

- continuous addition of $\mathrm{ClO}_{2}$ at $0.16 \mathrm{mg} / \mathrm{L}$ to $0.20 \mathrm{mg} / \mathrm{L}$; the residual at the outlet was around $0.04 \mathrm{mg} / \mathrm{L}$; - continuous addition of $\mathrm{NaClO}$ at $1.1 \mathrm{mg} / \mathrm{L}$ to $1.2 \mathrm{mg} / \mathrm{L}$; the residual at the outlet was 0.3 to $0.4 \mathrm{mg} / \mathrm{L}$.

Both procedures eliminate the macro-biofouling organisms. The cost of chlorine dioxide has been estimated to be some $30 \%$ higher than electrochlorination.

Three steel plants in Italy and two petrochemical plants in Italy and France use chlorine dioxide as an anti-fouling agent on seawater.

The Taranto steel plant, located in the south of the Italian Peninsula, uses $35 \mathrm{~m}^{3} / \mathrm{s}$ seawater for cooling a power station and numerous circuits with heat exchangers. Macro-biofouling is composed of mussels, barnacles, hydroids and serpulids; the biomass reaches $60 \mathrm{~kg} / \mathrm{m}^{2} /$ year. At the beginning of the treatment, in 1980 , the dosage was $0.5 \mathrm{mg} / \mathrm{L}$ continuously. Intermittent chlorine dioxide treatment was further applied:

- $0.5 \mathrm{mg} / \mathrm{L}$ for 9 hours per day in winter,

- $0.5 \mathrm{mg} / \mathrm{L}$ for 16 hours per day in summer.

The residual in the circuits of the power station remains in the range of 0.02 to $0.05 \mathrm{mg} / \mathrm{L}$. Monitoring of fouling by visual inspection with cameras and installation of fouling collectors showed no macrofouling development; a few juvenile settlements can be observed during the reproduction periods. As the water demand is in the range of 1.3 to $1.8 \mathrm{mg} / \mathrm{L}$, this indicates that all the $\mathrm{ClO}_{2}$ disappears prior to the discharge (Belluati et al., 1997).

At the petrochemical plant in Lavera (Mediterranean coast, south of France), the dosage is in the range of $0.15 \mathrm{mg} / \mathrm{L}$ to $0.20 \mathrm{mg} / \mathrm{L}$ depending on the seawater chlorine dioxide demand. This dosage is sufficient to maintain a $0.02 \mathrm{mg} / \mathrm{L}$ residual in all 
Table 3.32. - By-products formed by river waters treated with chlorine dioxide $\left(\mathrm{ClO}_{2}\right)$ and sodium hypochlorite $\left(\mathrm{Cl}_{2}\right)$. All data on chlorine dioxide and chlorine correspond to dosages with the exception of data on the Main river, corresponding to residual concentrations.

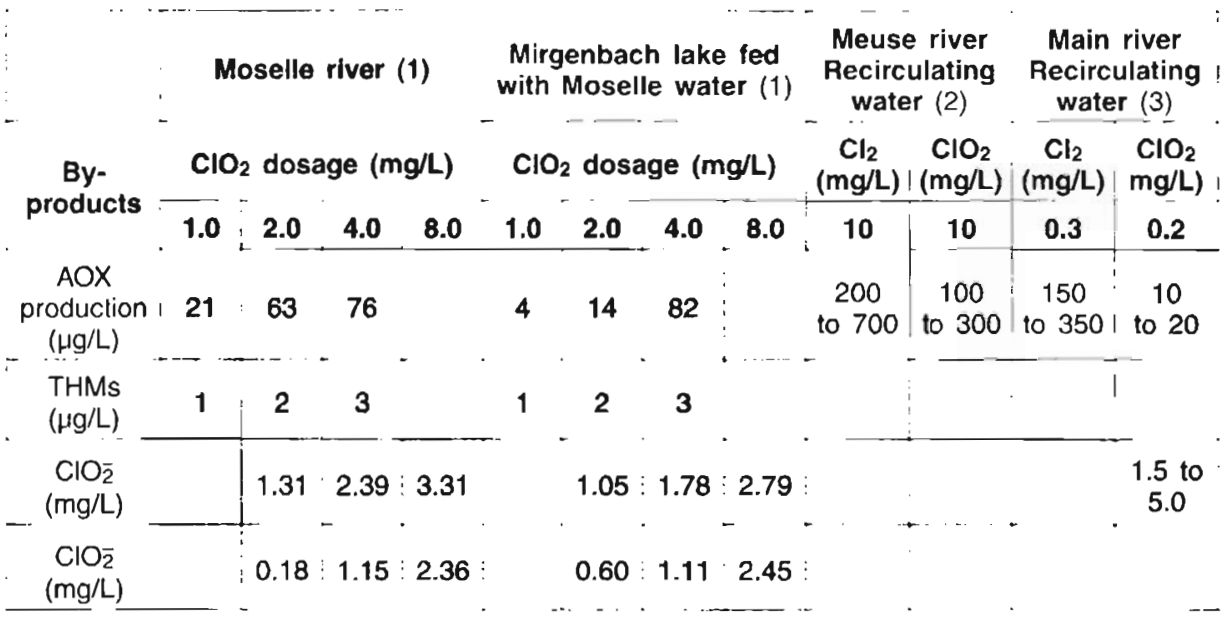

(1) Khalanski, 1993 with complements, (2) Duvivier, 1993, (3) Wasel-Nielen \& Baresel, 1997.

parts of the circuit needing protection against slime and macrofouling. The chlorine dioxide level is continuously monitored by amperometry with a detection threshold of $0.01 \mathrm{mg} / \mathrm{L}$, and the addition of $\mathrm{ClO}_{2}$ is determined by the residual target of $0.02 \mathrm{mg} / \mathrm{L}$.

\subsubsection{Environmental assessment}

\section{Treatments on freshwaters}

Three types of by-products can be found in natural waters treated with chlorine dioxide:

- residual chlorine dioxide $\mathrm{ClO}_{2}$, but this powerful oxidant disappears rapidly in the cooling circuit itself or in the discharge plume,

- weak oxidant ions: chlorites $\left(\mathrm{ClO}_{2}^{-}\right)$and chlorates $\left(\mathrm{ClO}_{3}^{-}\right)$, and possibly bromates $\left(\mathrm{BrO}_{3}^{-}\right)$,
- organics, including organohalogenated compounds (THMs, AOX) and aldehydes.

The formation yield of these products depends on the production yield of chlorine dioxide in the generator and on the chemical composition of the water, which determines the chlorine dioxide demand.

Table 3.32 gives data relative to the production of chlorite and chlorate ions and organohalogenated compounds in river water. Measurements in Moselle water show that, for an injection of between 1 and $8 \mathrm{mg} / \mathrm{L}$, $40 \%$ to $60 \%$ of the chlorine dioxide is found again in the form of chlorites. Chlorine dioxide treatment of river water or of a solution of humic acids can produce from $60 \%$ to $80 \%$ of 
Table 3.33. - Comparison of lethal concentrations $\left(L_{50}\right)$ of chlorine dioxide and chlorite ion for Daphnia and zebra fish (Montanat et al., 1980).

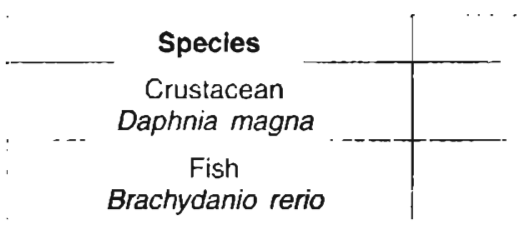

Compound
chlorine dioxide
sodium chlorite
chlorine dioxide
sodium chlorite

\section{$\mathrm{LC}_{50}(\mathrm{mg} / \mathrm{L})$}

$24 \mathrm{~h}: 0.30-0.42$

$24 \mathrm{~h}: 20.0$

$24 \mathrm{~h}: 0.34$

$48 h: 450.0$ chlorites (Doré, 1989). As for chlorates, the proportion in relation to the chlorine dioxide injected in Moselle water ranges between $10 \%$ and $30 \%$.

Chlorite and chlorate ions are transformed by anaerobic bacteria into chlorides by the chlorite dismutase enzyme; this is one step in the reduction of perchlorates as follows (Rikken et al., 1996) :

$\underset{\text { perchlorate }}{\mathrm{ClO}_{4}} \rightarrow \underset{\text { chlorate }}{\mathrm{ClO}_{3}} \rightarrow \underset{\text { chlorite }}{\mathrm{ClO}_{\overline{2}}} \rightarrow \underset{\text { chloride }}{\mathrm{Cl}}$

Chlorine dioxide produces very little THM $(<5 \mu \mathrm{g} / \mathrm{L})$, and forms only $10 \%$ to $50 \%$ of $\mathrm{AOX}$ in comparison with equivalent treatments with sodium hypochlorite, according to data in the table. Here again, formation of AOX is dependent on the quality of the water treated.

The toxicity of chlorine dioxide is far greater than that of chlorites, as found in toxicity tests performed in Seine water (Montanat et al., 1980) (Table 3.33). While chlorine dioxide is toxic in the short term in concentrations of $1 / 10 \mathrm{mg} / \mathrm{L}$, chlorites are toxic in the tens to hundreds of $\mathrm{mg} / \mathrm{L}$ range.

The toxicity of chlorite is very low when the concentration is below 10 $\mathrm{mg} / \mathrm{L}$ (Couri et al., 1982).
Chlorate toxicity is also very low for freshwater organisms, as found in a review of toxicity data by Van Wijk \& Hutchinson (1995) (Table 3.34). NOECs range from several tens to several hundreds of $\mathrm{mg} / \mathrm{L}$ for invertebrates and freshwater fish. Marine brown algae are the group of organisms most sensitive to chlorates, the longterm (6 months) NOEC is only $5 \mu \mathrm{g} / \mathrm{L}$.

With respect to the health risk of chlorine dioxide by-products in drinking waters, WHO 1993b did not set any limit for the following reason: "A guideline value has not been established because of chlorine dioxide's rapid breakdown and because the chlorite guideline value is adequately protective for potential toxicity from chlorine dioxide". The new U.S. maximum concentration level will be 0.8 $\mathrm{mg} / \mathrm{L}$ for chlorine dioxide (Richardson, 1997).

For chlorites, WHO 1993b recommends $0.2 \mathrm{mg} / \mathrm{L}$ as a provisional guideline and the new U.S. maximum concentration level is $1.0 \mathrm{mg} / \mathrm{L}$ (Table 3.25).

WHO 1993b established no guideline for chlorates, due to the present lack of data.

The new projected European Directive on drinking water set no limits 
for chlorites and chlorates (Ottaviani, 1997).

\section{Treatments on seawater}

As observed on freshwaters, the formation of THM following chlorine dioxide treatment of seawater is lower than that resulting from chlorination. Laboratory findings on seawater enriched with humic acid (Table 3.35) confirm that, at the same dosage in the range of $0.5 \mathrm{mg} / \mathrm{L}$ to $2.0 \mathrm{mg} / \mathrm{L}$, chlorine dioxide produces no more than $3 \%$ to $4 \%$ of the THM produced with hypochlorite treatments (Am- brogi, 1997). At higher chlorine dioxide dosages (20 to $40 \mathrm{mg} / \mathrm{L}$ ), THM formation increases up to $58 \%$ of the THM formed with chlorine.

With a chlorine dioxide dosage of $0.2 \mathrm{mg} / \mathrm{L}$ at the Vandellos II nuclear power station, operated by UNESA in Spain, the $\mathrm{ClO}_{2}$ residual at the outlet was about $0.04 \mathrm{mg} / \mathrm{L}$ and the THM concentration was estimated at 3.5 $\mu \mathrm{g} / \mathrm{L}$, whereas hypochlorite treatment generates $30 \mu \mathrm{g} / \mathrm{L}$ of $\mathrm{THMs}$.

At the Taranto steel plant, intermittent chlorine dioxide treatment at a dosage of $0.5 \mathrm{mg} / \mathrm{L}$ for 9 to 16 hours

Table 3.34. - Comparative toxicity of the chlorate ion for aquatic organisms (Van Wijk \& Hutchinson, 1995). EC50: median effect (lethal) concentration, LOEC : lowest observed effect concentration, NOEC : no observed effect concentration.

\section{Taxons}

Marine and freshwater bacteria

\section{Marine and Freshwater Microalgae} (phytoplankton)

Marine Macroalgae

(Fucus vesiculosus, Fucus serratus)

Marine algae in mesocosms ( 6 months)

Freshwater Invertebrates

Freshwater Fish

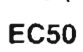

38.823

(34.510-43.137)!

563.1

(298-1350)

0.1

(0.08-0.13)

2442.4

(880-12549)

3815.3

(<31-10667)
NOEC

LOEC

1.7

(0.1-1900)

20.7

(0.1-3340)

0.1

(0.015-0.58)

0.015

3325

8628
118.2

(0.05-3137)

0.06

(0.005-0.58)

0.005

600

109.6

(35-784)

Table 3.35. - THM formation $(\mu \mathrm{g} / \mathrm{L})$ in seawater treated with chlorine dioxide and sodium hypochlorite after addition of standard humic acids (T.O.C $=5 \mathrm{mg} / \mathrm{L}$ ), temperature : $35{ }^{\circ} \mathrm{C}$, reaction time: one hour. (Ambrogi, 1997).

\section{Dosage of oxidizing agent $(\mathrm{mg} / \mathrm{L})$}

\begin{tabular}{|c|c|c|c|c|c|}
\hline Oxidizing agent & 0.50 & 1.00 & 2.00 & 20.00 & 40.00 \\
\hline Chlorine dioxide & $0.93 \mu \mathrm{g} / \mathrm{L}$ & $1.63 \mu \mathrm{g} / \mathrm{L}$ & $4.25 \mu \mathrm{g} / \mathrm{L}$ & $452.02 \mu g / L$ & $460.48 \mu \mathrm{g} / \mathrm{L}$ \\
\hline Sodium hypochlorite & $22.42 \mu \mathrm{g} / \mathrm{L}$ & $48.52 \mu \mathrm{g} / \mathrm{L}$ & $112.90 \mu g / L$ & $788.28 \mu \mathrm{g} / \mathrm{L}$ & $787.63 \mu \mathrm{g} / \mathrm{L}$ \\
\hline
\end{tabular}


a day generates no THMs and a mussel farm located close to the outlet is not affected by the discharges from the plant (Belluati et al., 1997).

ENEL has conducted some studies on the toxicity of chlorine dioxide for non-target marine organisms. The first test was intended to evaluate sperm toxicity and embryotoxicity in the seaurchin Sphaerechinus granularis. The sperm inactivation test, with 10 minutes' contact before fertilization of the ovocyte, showed that a significant reduction in the percentage of fertilized eggs occurred at $0.74 \mathrm{mg} / \mathrm{L}$. The development of embryos was blocked at the morula stage at concentrations higher than $2.0 \mathrm{mg} / \mathrm{L}$, whereas there is no significant difference with the untreated control at concentrations of $0.74 \mathrm{mg} / \mathrm{L}$ and $0.22 \mathrm{mg} / \mathrm{L}$ (Geraci et al., 1993).

Acute toxicity of chlorine dioxide for young sea bass (Dicentrarchus labrax of $7 \mathrm{~g}$ ) showed a $96-\mathrm{h} \mathrm{LC}_{50}$ of 20.8 $\mu \mathrm{g} / \mathrm{L}$ while there was no significant toxicity after $96 \mathrm{~h}$ at $15 \mu \mathrm{g} / \mathrm{L}$ (Ambrogi et al., 1994). Under the same experimental conditions on the same species with sodium hypochlorite, the TRO 96-h LC $_{50}$ was $78.6 \mathrm{\mu g} / \mathrm{L}$ (Saroglia \& Scarano, 1974).

\subsubsection{Ozone}

Ozone is an allotropic species of oxygen obtained by means of the ionisation of oxygen by the action of an electric field.

Molar mass : $48 \mathrm{~g} / \mathrm{mole}$

Density vs air : 1.657
Volumetric mass at $0^{\circ} \mathrm{C}, 760 \mathrm{~mm} \mathrm{Hg}$ : $2.134 \mathrm{~kg} / \mathrm{m}^{3}$.

Ozone is produced on-site from air or pure oxygen. Two types of ozone generators are available: plated and tubular generators; the largest units, which can produce 5 to $10 \mathrm{~kg} / \mathrm{h}$, are tubular generators (Duvivier et al., 1996). Recently, Mitsubishi Electric developed a storage system (MABOS), which makes it practical to apply intermittent ozonation to cooling water (Nakayama et al., 1997). This system is tested since 1996 by Ontario Hydro.

Ozone is very volatile compared with other oxidizing biocides. McCoy et al. (1990), compared the volatility of various oxidants in cooling towers. From this study, the following order of volatility appeared:

ozone $>$ chlorine $>$ chlorine dioxide $>$ chloramine $>$ hypochlorous acid $>$ hypobromous acid.

Compared to other oxidizing agents, ozone shows two major specificities.

Ozone is a stronger oxidant than chlorine, it can decompose high molecular organic substances like humic acids to produce low molecular compounds such as aldehydes and carboxylic acids. It is thus a very effective sterilisation agent whose main appliances are in desinfection of drinking water and bathing waters but also in food industry. The use of ozone decreases the organic carbon content of water and AOX formation (Duvivier, 1993).

On the contrary, this property is responsible for the generation of bro- 
minated oxidants in sea water. Ozone oxidises the bromide ions almost instantaneously to form active bromine, producing the same oxidising products as those occuring after chlorination. This is why ozonation of sea water is not suitable as an anti-fouling treatment.

Ozone decomposes rapidly in water, its half-life time in pure water is a few hours but in raw waters used for cooling purpose, the half-life is reduced to minutes by consumption with organic matters. The rate of decomposition also depends on the $\mathrm{pH}$, it increases with increasing $\mathrm{pH}$. At acidic $\mathrm{pH}$, the dominant species is molecular ozone $\left(\mathrm{O}_{3}\right)$, but at alkaline $\mathrm{pH}$, ozone generates very short-lived (micro-seconds) hydroxy free radicals $\left(\mathrm{OH}^{\circ}\right)$.

\subsubsection{Experimental studies}

In Switzerland, in a small closed cooling water system $\left(10-12 \mathrm{~m}^{3} / \mathrm{s}\right)$, a two years period continuous treatment with approximately $50 \mu \mathrm{g} / \mathrm{L}$ was found effective against bacterial slime and total bacteria counts decreased by a factor of about 100 times (Wellauer \& Kyas, 1987; Wellauer and Oldani, 1990). Some corrosion was observed on C-steel materials; corrosion rate was 1.5 times higher when ozonising water was used but no corrosion was recorded in the presence or absence of ozone for stainless steel alloys, titanium and also copper alloys. A pilot plant $\left(1,000 \mathrm{~m}^{3} / \mathrm{h}\right)$ was set up at the EVS Heilbronn coal-fired power station in Germany where the cooling water is conditioned river water.

In Canada, experimental data on Zebra mussels mortality in ozonised water (Claudi \& Mackie, 1994) show that mortality rate for adult mussels depends on the water temperature. At the ozone concentration of $2 \mathrm{mg} / \mathrm{L}$, the $90 \%$ to $100 \%$ mortality level is reached in 9 days at $4{ }^{\circ} \mathrm{C}$ and in 5 days at $20^{\circ} \mathrm{C}$ (Table 3.36 ).

Experimental trials have been made on Zebra mussels and freshwater snails in Belgium (Duvivier et al., 1996). It was observed that adult Zebra mussels $(2 \mathrm{~cm}$ to $3 \mathrm{~cm}$ ) exposed to dissolved ozone keep their shell open but stop to filter the water. At $21^{\circ} \mathrm{C}$, the $100 \%$ mortality rate is observed at a concentration of 0.32 $\mathrm{mg} / \mathrm{L}$ in 39 days (Table 1 ). Ozone is also very efficient in preventing the settlement of mussel's larvae and there is no production of byssal threads for ozone concentration in the range of $20 \mu \mathrm{g} / \mathrm{L}$ to $30 \mu \mathrm{g} / \mathrm{L}$.

The fresh water snail Physa acuta is more susceptible to ozone than adult Zebra mussels : at $21^{\circ} \mathrm{C}, 100 \%$ mortality is observed in 10 days for $0.32 \mathrm{mg} / \mathrm{L}$ (Table 3.36).

Lethal concentration for $100 \%$ $\left(\mathrm{LC}_{100}\right)$ of the tested adult Zebra mussels at temperatures of $20^{\circ} \mathrm{C}$ to $21^{\circ} \mathrm{C}$ are represented on the figure 3.23. A power function curve can be fitted to the data for exposure time _ 2 days :

$$
\begin{gathered}
\mathrm{LC}_{100}(\mathrm{mg} / \mathrm{L})=17.73 * \mathrm{t}^{-1.1127} \\
\mathrm{r}^{2}=0.91, \text { with } \mathrm{t}=\text { exposure time } \\
\text { in days. }
\end{gathered}
$$


Table 3.36. - Experimental data on the mortality of fresh water molluscs exposed to dissolved ozone.

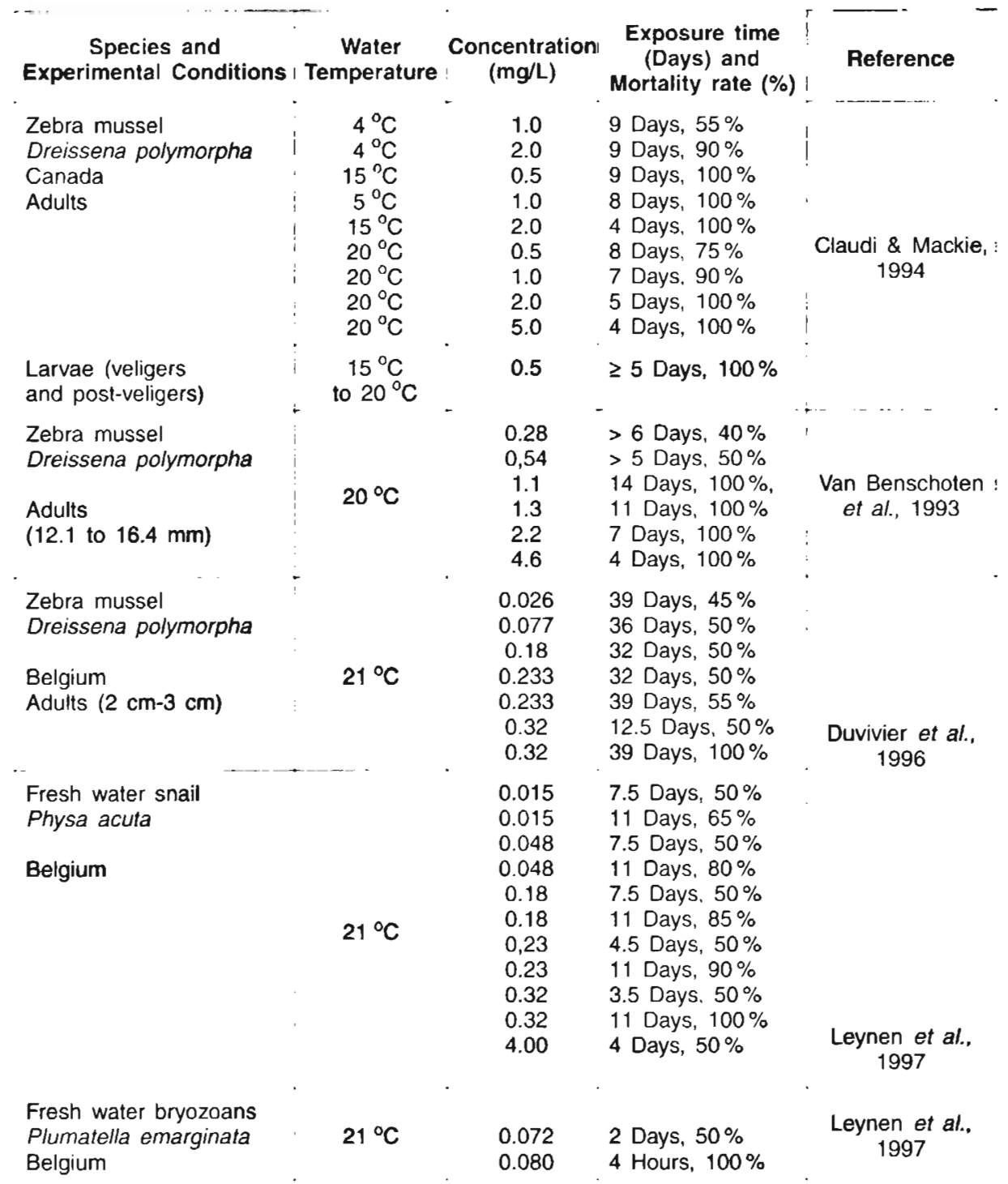




\section{Ozone continuous treatment}

Adult Zebra mussels

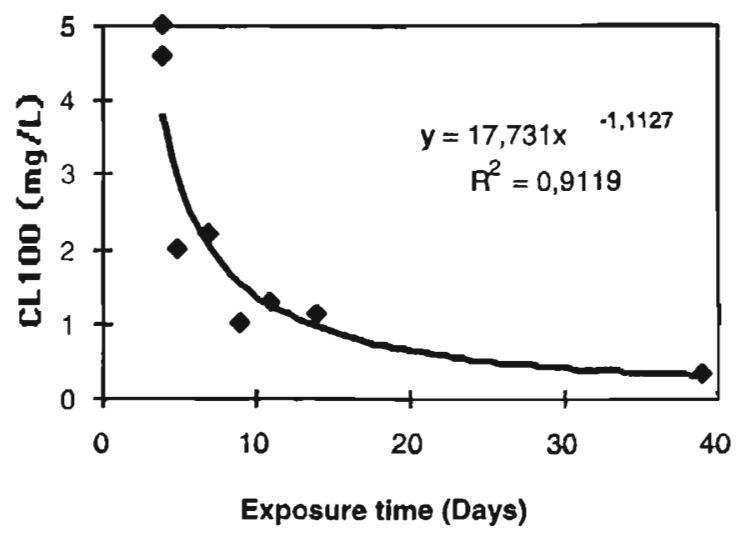

Fig. 3.23. - Ozone lethal concentration for adult zebra mussels depending on the exposure time.

The young colonies ot the bryozoan Plumatella emarginata are very sensitive to ozone : $L C_{100}=0.08$ $\mathrm{mg} / \mathrm{L}$ with a 4 hour exposure. Statoblasts and large colonies are more resistant. Nevertheless, Leynen et al., (1997), concluded that a continuous low level ozone treatment up to 0.1 $\mathrm{mg} / \mathrm{L}$ is sufficient to eliminate Bryozoans and Zebra musels; however, at $20 \mu \mathrm{g} / \mathrm{L}$, there is no effect on zebra mussels, Duvivier et al., 1996.

Intermittent application of ozone has been tested in Canada in a test rig at Lake Ontario Hydro (Nakayama et al., 1997), Addition of about 10 $\mathrm{mg} / \mathrm{L}$ of ozone leading to a residual of 2 to $8 \mathrm{mg} / \mathrm{L}$ for 6 minutes twice a day was found efficient on microfouling which was reduced by $94 \%$ to $99 \%$. Zebra mussel mortality was very low $(3 \%)$, but a $30 \%$ reduction in tissue weigth was observed. In this experiment, the ozone storage system developed by Mitsubishi Electric was used.

\subsubsection{Ozone testing at industrial sites}

On-site studies performed in the USA, at the Bergen power station on the Delaware river, have been clearly negative for ozone (Sugam, 1985). Ozone is an efficient biocide against the bacterial slime but it produces deposits of manganese dioxide and the cost of ozone treatment is much higher compared to chlorine.

Ozone was implemented in 1995 at the Mol power station, operated by Electrabel in Belgium : injection in the inlet canal at $0.3 \mathrm{mg} / \mathrm{L}$, at pH 8 ozone half-life is 25 minutes. The ozone consumption was very rapid and the effect on Zebra mussel was limited in the canal to only the first 50 meters. 
The use of ozone as a biocide still remains a very expensive method, estimated to 3.8 times the cost sodium hypochlorite (Duvivier et al., 1996).

At the Seraing power station, in Belgium on the river Meuse, ozone dosing is implemented at $1.0 \mathrm{mg} / \mathrm{L}$ in the auxiliary cooling system. This circuit is the make-up of the main semiclosed cooling system. In this system, the concentration factor reaches 1.8 . In the cold water basin of the cooling tower, the ozone residual is as low as $5 \mu \mathrm{g} / \mathrm{L}$. This treatment kills $100 \%$ of bivalves (Corbicula and Dreissena) in 18 days. Total bacteria decreases below $100 / \mathrm{ml}$ and DOC was reduced by $30 \%$.

In Germany, the recirculating cooling system of the air separation plant at Höchst is continuously treated by ozone since 1985. This circuit, fed with river Main water, comprises four cooling towers, the recirculating rate is $4,800 \mathrm{~m}^{3} / \mathrm{h}$ (Wasel-Nielen and Baresel, 1997). Ozone is added at 0.10 to $0.15 \mathrm{mg} / \mathrm{L}$ and the ozone is measured in the water supply at 0.05 to $0.08 \mathrm{mg} / \mathrm{L}$. The water is clear and colourless "like a mountain stream". A slight reduction of the AOX was measured in the cooling system compared to river Main levels ( 5 to $30 \mu \mathrm{g} / \mathrm{L}$ ). Corrosion of copper alloy was stopped by addition of a nonferrous corrosion inhibitor. New systems are ozonised since 1992 with a mean recirculating rate of $12,000 \mathrm{~m}^{3} / \mathrm{h}$ to $22,500 \mathrm{~m}^{3} / \mathrm{h}$. The ozone level must be at least $0.1 \mathrm{mg} / \mathrm{L}$ in the supply water, it is sufficent to eliminate all biological deposits in the heat exchangers.
In the Netherlands, ozonation is applied at a cooling tower assisted power station (RoCa) in Rotterdam. Make-up water is filtered over sand filters, improving the water quality which enables the use of ozone. A recirculating cooling water system at a chemical plant is also treated with ozone in the Netherlands. This system is completely made out of stainless steel and fed with demineralised water. The system was put in operation in 1995 and the results have sofar been excellent.

\section{Safety of workers}

The high volatility of ozone causes enrichment of ozone gas in the vicinity of treated waters. The air concentration limit to protect the workers is $0.2 \mathrm{mg} / \mathrm{m}^{3}$. Ozone generators are presently equipped with removing systems destroying the excess ozone in the air using different processes: ther-mal destruction, activated carbon, catalytic systems.

\subsubsection{Ozone environmental assessment}

Although the formation energy of ozone is high, the application of ozone is often refered to as more environmentally acceptable than hypochlorite, since it leads to less formation of trihalomethanes (THMs) and extractable organic halides (EOX).

Compared chlorination by-product formation, relatively little attention has been paid to by-product formation re- 
sulting from ozonation. Ozonation may however lead to formation of bromate $\left(\mathrm{BrO}_{3}\right)$ and aldehydes (Cavanagh et al., 1992). The new WHO guidelines for drinking water (WHO, 1993b; Table 3.25), recommands a limit of $25 \mu \mathrm{g} / \mathrm{L}$ for bromate and a new proposed regulation in the European Union countries (Ottaviani, 1997) and in the USA (Richardson, 1997), require a lower limit at $10 \mu \mathrm{g} / \mathrm{L}$.

The formation of bromates by ozonation can be reduced at $\mathrm{pH}<7$, but the $\mathrm{pH}$ of most of the large European waters suitable for cooling purposes is frequently higher. At the Höcht plant on the river Main, in Germany, no bromate was detected in the recirculating cooling system treated with ozone at 0.10 to $0.15 \mathrm{mg} / \mathrm{L}$, but the detection level for bromate was $100 \mu \mathrm{g} / \mathrm{L}$ (Wasel-Nielen \& Baresel, 1997).

By-product formed by ozonisation at a dosage of 6 to $12 \mathrm{mg} / \mathrm{L}$ of effluent from a wastewater treatment plant in La Roche-sur-Yon (France) was investigated by Langlais et al. (1992). Ozo- nisation led to complete or partial elimination of aromatics (allyltoluene, dichlorobenzene, dimethoxubenzene...) and non saturated fatty acids, whereas no significant change on the concentration of long-chain saturated fatty acids was observed. Aldehydes (heptanal, nonanal) and short-chain saturated fatty acids appeared or increased in concentration.

Short-term toxicity tests carried out on the ozonised effluent showed no mortality on fish (Brachydanio rerio) and crustacean (Artemia salina), but some growth inhibition on the green algae scenedesmus subspicatus. These tests were made with no residual dissolved ozone and the conclusion was that ozonisation of wastewater does not generate acute toxicity.

Dissolved ozone is very toxic for fish, as shown on juveniles of fresh water fishes (Table 3.37). However, the high ozone consumption in river waters can be used to eliminate the residuals by diluting the ozonised water.

Table 3.37. - Toxicity date on ozone for juveniles of fresh water fish.

\begin{tabular}{|c|c|c|}
\hline $\begin{array}{c}\text { Species } \\
\text { Carp } \\
\text { Cyprius carpio } \\
1.1 \mathrm{~cm} \\
\text { Chub }\end{array}$ & LC50, $48 \mathrm{~h}$ & Reference \\
\hline $\begin{array}{c}\text { Leuciscus cephalus } \\
1.7 \mathrm{~cm}\end{array}$ & $0.043 \mathrm{mg} / \mathrm{L}$ & \\
$\begin{array}{c}\text { Sharptooth Catfish } \\
\text { Clarias gariepinus } \\
1.1 \mathrm{~cm}\end{array}$ & $0.036 \mathrm{mg} / \mathrm{L}$ & Duvivier, 1993 \\
\hline
\end{tabular}




\subsubsection{Other oxidizing compounds}

\section{Bromine}

In some freshwater CWS, sodium hypochlorite is dosed in combination with $\mathrm{NaBr}$. Some practical experiments are presently being carried out in the Netherlands. From an antifouling efficacy point of view hypochlorite dosing in combination with $\mathrm{NaBr}$ - in freshwater - may indeed lead to a reduction of the required dose, since free bromine is not totally dissociated at basic $\mathrm{pH}$ and bromamines have proven to be more toxic than chloramines. In seawater, with natural $\mathrm{Br}$ concentrations of $65 \mathrm{mg} / \mathrm{L}$, additional dosing of $\mathrm{NaBr}$ makes no sense.

\section{Hydrogen peroxide and peracetic acid}

Hydrogen peroxide is sometimes applied an algicide or biocide in small recirculating CWS. Hydrogen peroxide disintegrates easily and reacts with some materials. One practical application in a CWS is known in the Netherlands, in the food sector. This is a recirculating system, fed with demineralised water, with hydrogen peroxide dosed continuously at a concentration of $15 \mathrm{ppm}$. The concentration is maintained at a high level, because bacterial counts in this system need to be low. A motive to choose for peroxide in this CWS is that it does not add salts $\left(\mathrm{Cl}^{-}\right)$to the cooling water.

Hydrogen peroxide does not produce organohalogenated compounds and there are no known harmful decomposition products. Its use for CWS treatments is mainly limited by a poor anti-fouling activity at low concentrations and at low temperatures and by the inactivation by bacterial enzymes (catalases and peroxidases).

Peracetic acid, or peroxyacetic acid $\left(\mathrm{CH}_{3} \mathrm{CO}_{3} \mathrm{H}\right)$, is a weak acid, which does not exist as a pure compound. The peracetic acid solutions are equilibrium mixtures of acetic acid and hydrogen peroxide:

$$
\begin{aligned}
\mathrm{CH}_{3} \mathrm{CO}_{3} \mathrm{H} & +\mathrm{H}_{2} \mathrm{O} \leftrightarrow \mathrm{CH}_{3} \mathrm{CO}_{2} \mathrm{H} \\
& +\mathrm{H}_{2} \mathrm{O}_{2}
\end{aligned}
$$

Commercial solutions for water treatment applications are available at concentrations of $1 \%$ to $15 \%$. Peracetic acid is very corrosive at higher concentrations.

The final decomposition products are methane, carbon dioxide, oxygen and water, but acetic acid is the major intermediate compound. According to Fraser (1986) the desinfection activity is based on the production of oxygen free radicals breaking the chemical bounds $\mathrm{SH}$ and $\mathrm{S}-\mathrm{S}$ in cell membrane's enzymes.

In the food sector industry, peracetic acid is applied on a small scale for desinfection, (Swinnen, 1995), but no applications in large CWS are known. However, peracetic acid seems to have a greater efficacy than glutaraldehyde and isothiazolones for elimination of Pseudomonas aeruginosa, common slime forming bacteria, and could be used to control biofilms in cooling towers (Kramer, 1997). The dosage in cooling water should be in the range of 1 to $10 \mathrm{mg} / \mathrm{L}$ for a contact time of 1 to 3 hours. 


\subsection{CHEMICAL TREATMENTS WITH NON-OXIDIZING COMPOUNDS}

This category groups mineral or organic components with biocidal effects on the main species responsible for biofouling of cooling systems. The composition of the commercial products, particularly in the case of organic products, is generally more complex than that of the "active substance"; in this case, the chemical and ecotoxicological properties of the product may differ from those of the active substance. For this reason, it appears to us to be necessary in certain cases to identify the products by their commercial brand name.

While oxidising biocides exercise non-specific biocidal action on the target organisms, from bacteria to mussels, organics have more specific action, for example on weeds (algicides), or molluscs (molluscicides). Their greater or lesser toxicological specificity is an important characteristic of these anti-fouling agents.

\subsubsection{Organic agents}

Toxics for molluscs were produced in the Sixties to combat parasitic diseases, such as bilharziosis, in which aquatic snails are intermediate hosts of the parasitic agent. Some of these products are also very toxic for Zebra mussels (Hoestland, 1972). In a review of toxicity data on molluscicides used in African continental waters, Dejoux (1988) concluded that they cause mortality of non-target organisms. For water treatment against macro-biofouling in industrial systems, specific products have been developed.

Three major groups of organics currently used in industry to control fouling in cooling water systems can be identified:

- products containing isothiazolones as the toxic substance,

- products containing quaternary amines as the toxic substance,

- other organics, such as glutaraldehyde, 2,2,-dibromo-3-nitrilo-propionamide (DBNPA), 2-bromo-2-nitropropane-1,3,-diol (BNPD), methylenebisthiocyanate, 2,-dithiobisbenzamide, b-bromo-b-nitrostyrene, etc.

This is probably the situation in most European Countries, but it should be added that use of products containing filming agents, composed of fatty amines, is developing for antifouling applications.

Figure 3.24. shows the chemical structure of QACs, isothiazolones and fatty amines.

All have the common property of not being detected as toxic (at least for short-term applications) by the target organisms. Thus, bivalve molluscs continue to filter the water when the product is added at a non-excessive dosage, and they are exposed to the toxic until the first detrimental effects cause a behavioural response : valve closure, reduction of the water filtration rate.

As a consequence, most of these organic agents are effective for shortterm applications : 12 to 48 hours, while others require a few days' exposure (Table 3.38). They are generally used in recirculating cooling water systems. 
clams (mortality rate $\geq 95 \%$ ).

\section{Commercial \\ Brand \\ Active \\ substance}

\section{Concentration}

Target
organism

$$
15.0 \mathrm{mg} / \mathrm{L}
$$

Asiatic clam $\quad 25.0 \mathrm{mg} / \mathrm{L}$

$25.0 \mathrm{mg} / \mathrm{L} \quad 3.25 \mathrm{mg} / \mathrm{L}$

$15.0 \mathrm{mg} / \mathrm{L}$

$10.0 \mathrm{mg} / \mathrm{L}$

$14.3 \mathrm{mg} / \mathrm{L}$

$14.3 \mathrm{mg} / \mathrm{L}$

(Betz)

ADBAC

(QUAC) +

dodecylguanidine। Zebra mussel

$\mathrm{H}-130 \mathrm{M}$

(Calgon)

DDAC

(QUAC)

Zebra mussel :

$2.0 \mathrm{mg} / \mathrm{L}$

$2.0 \mathrm{mg} / \mathrm{L}$

$2.0 \mathrm{mg} / \mathrm{L}$

$1.0 \mathrm{mg} / \mathrm{L}$

Bulab 6002

(Buckman)

Polyquat

TCMTB

Isothiazole

Bulab 6009

(Buckman)

TD 2335

(Atochem)

Pesticide + alkylamine

Filming agent

Mexel 432

Falty amines

Filming agent

Zebra mussel : $\quad 1.0 \mathrm{mg} / \mathrm{L}$
$0.5 \mathrm{mg} / \mathrm{L}$

$1.0 \mathrm{mg} / \mathrm{L}$

Zebra mussel :

$2.0 \mathrm{mg} / \mathrm{L}$

$4.0 \mathrm{mg} / \mathrm{L}$

$8.0 \mathrm{mg} / \mathrm{L}$

$0.25 \mathrm{mg} / \mathrm{L}$

$0.50 \mathrm{mg} / \mathrm{L}$

$2.0 \mathrm{mg} / \mathrm{L}$

$5.0 \mathrm{mg} / \mathrm{L}$

$3.0 \mathrm{mg} / \mathrm{L}$

(1.27-3.52)

Zebra mussel :

$5.1 \mathrm{mg} / \mathrm{L}$

$2.0 \mathrm{mg} / \mathrm{L}$

$2.0 \mathrm{mg} / \mathrm{L}$

$3.5 \mathrm{mg} / \mathrm{L}$

(residual)

$0.3 \mathrm{mg} / \mathrm{L}$

$0.6 \mathrm{mg} / \mathrm{L}$

$1.2 \mathrm{mg} / \mathrm{L}$

$2.4 \mathrm{mg} / \mathrm{L}$

$4.8 \mathrm{mg} / \mathrm{L}$

$0.07 \mathrm{mg} / \mathrm{L}$

$0.15 \mathrm{mg} / \mathrm{L}$

$0.30 \mathrm{mg} / \mathrm{L}$

$0.60 \mathrm{mg} / \mathrm{L}$

$1.20 \mathrm{mg} / \mathrm{L}$

$6.0 \mathrm{mg} / \mathrm{L}$

Zebra mussel :

$10 \mathrm{mg} / \mathrm{L}$

$0.7 \mathrm{mg} / \mathrm{L}$

$1.2 \mathrm{mg} / \mathrm{L}$

$2.0 \mathrm{mg} / \mathrm{L}$

$0.1 \mathrm{mg} / \mathrm{L}$

24

$0.5 \mathrm{mg} / \mathrm{L}$

$0.9 \mathrm{mg} / \mathrm{L}$

8

\section{8}

48

8

19

\section{Exposure \\ time \\ (hours)}

24

24

12

24

24

12

12

24

48

12

24

48

24

72

72

24

72

120

24

Temperature :

$\left({ }^{\circ} \mathrm{C}\right)$

Reference

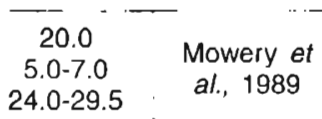

11.0

15.0-20.0 Lyons et al., !

19.0

14.5

20.0

15.0

20.0

15.0

10.0

15.0

10.0

5.0

22.0

18.0

14.0

Muia et al., 1993

Petrille \&

Werner, 1993 :

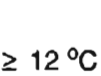

Command \& : Matthews, 1994

826

680

313

244

197

$>825$

$22.0-25.0$

McMahon et al., 1990

485

313

260

Piccirillo et al., 1994

Piccirillo et al., 1995

20.0

Khalanski, 1993

3h/day

for 30

days

$18^{\circ} \mathrm{C}$

3h/day

for 15

days

$18^{\circ} \mathrm{C}$

Giamberini et: al., 1994

Hoestland, 1972

Sheide, 1997

Hoestland, 1972 


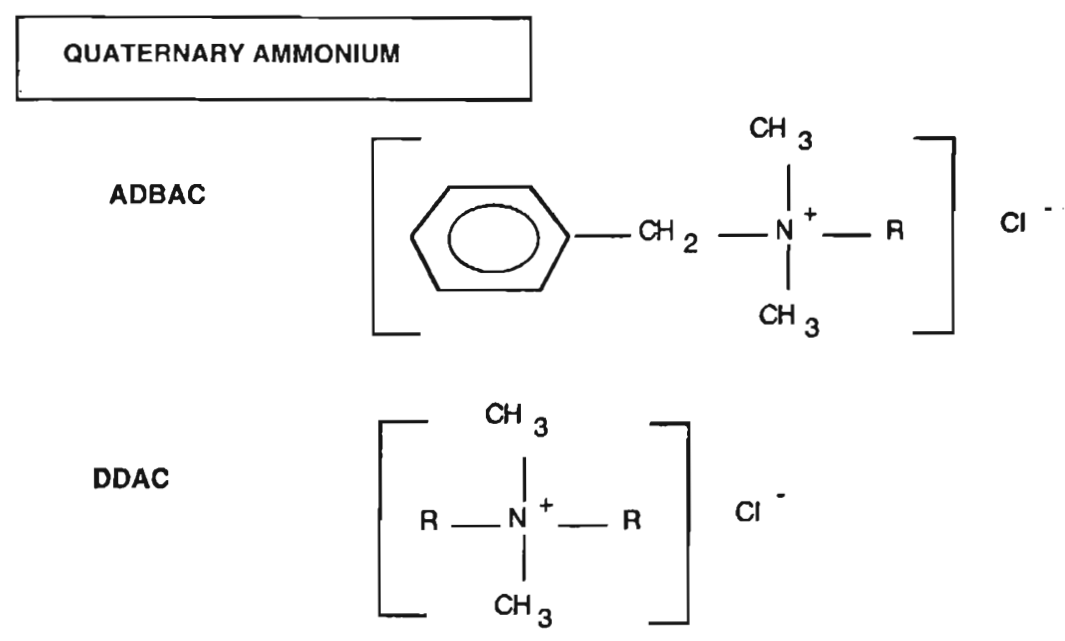

ISOTHIAZOLONES

$$
\text { BENZOTHIAZOLES }
$$
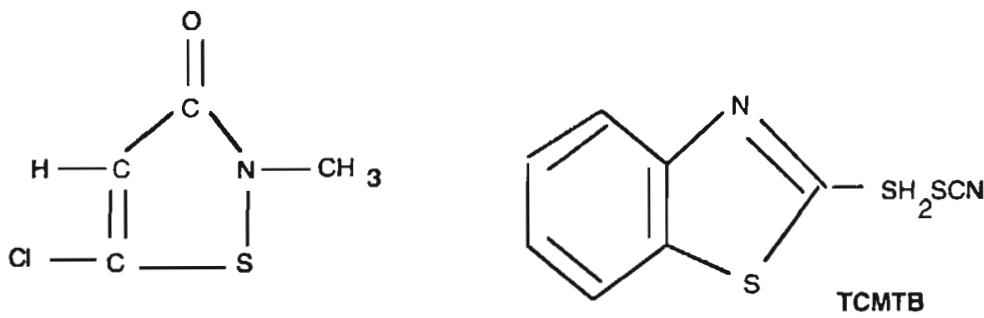

\section{FATTY AMINES}

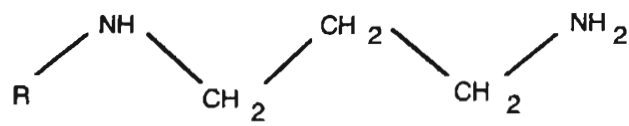

Fig. 3.24. - Chemical structure of some organic anti-fouling agents. 


\subsubsection{Quaternary ammonium compounds (QAC)}

This chemical category has long been known to have strong bactericidal properties. Some products in particular are used as molluscicides in industrial systems :

- Clam Trol from Betz, whose active substance is an ADBAC (Alkyl dimethyl benzyl ammonium chloride), associated with dodecylguanidine;

- H-130 M, from Calgon, whose active substance is a DDAC (didecyl dimethyl ammonium chloride);

- Bulab 6002, from Buckman, whose active substance is a poly [oxyethylene(dimethyliminio)ethylene (dimethyliminio)ethylene dichloride].

Their spectrum of action is wide, ranging from micro-organisms to molluscs. The toxic effect is due to destruction of the cellular membrane of bacteria or the destruction of branchiae of molluscs. Some of these products act rapidly; others require longer exposure. Their effectiveness is heavily dependent on water temperature, which is to say the physiological activity of the organisms (Petrille \& Werner, 1993).

Treatments are of the "periodic" type (see 3.1), and are applied 1 to 6 times a year depending on the site and the system, with exposure times of 6 to 24 hours. One example is given by Command \& Matthews (1994) who treated a cooling water system supplied by water from Lac Saint-Clair (Canada) with DDAC in two injections at $1 \mathrm{mg} / \mathrm{L}$ for 24 hours in mid-July and late September. These periods were chosen due to the water temperature, as the product is less effective below $12{ }^{\circ} \mathrm{C}$.

QACs are surfactants which are adsorbed on suspended matter in water or on colloids such as humic acids. To reduce the concentration of active compounds in the treated water before discharge, clay is added, resulting in immediate detoxification. The bentonite concentration required to detoxify the discharged water is in the range of $5 \mathrm{mg} / \mathrm{L}$ to $40 \mathrm{mg} / \mathrm{L}$.

Degradation of ADBAC has been measured by carbon dioxide production tests; $66 \%$ is degraded in 29 days in aerobic conditions with an initial concentration of $10 \mathrm{mg} / \mathrm{L}$ (Dobbs et al., 1995).

QACs are not metabolized by aquatic organisms; they are but little accumulated in the consumable parts of fish (factor 40 to 50); they are immobilized in the ground and do not pass into underground waters (Schroenig et al., 1995).

\subsubsection{Isothiazolones, benzothiazoles}

3-isothiazolone compounds exhibit high toxicity toward micro-organisms, and are used to control bacterial slime in recirculating cooling water systems.

Krzeminski et al., 1975a, have investigated the degradation process of 3-isothiazolone. They found that these compounds are rapidly degraded in aqueous systems by hydrolysis (at basic $\mathrm{pH}$ ) and by biological processes. Degradation products have no 
special toxicity toward aquatic organisms (Krzeminski et al., 1975b).

Benzothiazoles are mainly used as vulcanization accelerators for rubber, but they also have uses as slimicides, fungicides and herbicides. TCMTB (2-(thiocyano-methylthio)-benzotiazole) is effective against Zebra mussels in low concentrations, but requires exposure times of at least 10 days (Table 3.38).

TCMTB also hydrolyzes in alkaline waters and is partially adsorbed on suspended matters. According to Buckman Laboratories, TCMBT is rapidly degraded in aerobic conditions (half-life of 3.7 days). However, the degradation pathway of benzothiazoles is relatively complex, comprising hydrolysis in anaerobic and aerobic conditions, biomethylation and photolysis. The recent isolation of bacteria (Rhodococcus) capable of growth on first-stage degradation by-products is an important finding for elucidating the degradation pathway (De Wever \& Verachter, 1997).

\subsubsection{Filming agents}

Some long-chain alkylamines (fatty amines) destroy the gill tissues of aquatic organisms by acting directly on the cell membrane, and/or by combination with the mucous layer produced by the gills.

TD 2335 (Elf Atochem) contains, as active agent, a dimethylalkylamine salt of an algicide and herbicide compound: endothall. Extensive studies have been made on the degradation and aquatic toxicity of endothall. Endothall disappears rapidly in natural waters, with a half-life of less than 1 day.

Thus, TD 2335 offers the dual efficacy of a pesticide and of a filming agent. On-site trials at the Toledo power station (Ohio) showed that 8 hours of application at $3.0 \mathrm{mg} / \mathrm{L}$ is enough to kill Zebra mussels. The decrease in concentration over long stretches including a fly ash pond resulted in low residual concentrations of the active agent, and the absence of toxicity on non-target organisms (Piccirillo et al., 1994).

Mexel 432 is a commercially available compound primarily constituted of long-chain aliphatic amines. In aqueous emulsions, this product forms a film on the cell membranes causing destruction of tissues in a varying proportion depending on the dosage. It can be effective against bivalves on a periodic treatment basis : at residual concentrations of 3.5 $\mathrm{mg} / \mathrm{L}$, the product rapidly causes major damage to the gills of Zebra mussels and causes death after 19 hours of exposure (Khalanski, 1993). The efficacy of long-term intermittent treatments on zebra mussels has also been shown in experiments: a dosage of 3 hours per day at $6 \mathrm{mg} / \mathrm{L}$ kills $100 \%$ of zebra mussels; the effective concentration corresponding to the residual was probably close to 3 $\mathrm{mg} / \mathrm{L}$ (Giamberini et al., 1994). In this experiment, it was also observed that byssus thread formation was reduced or inhibited by intermittent Mexel 432 
injections. It has a broad spectrum of action on microfouling and macrofouling in both seawater and freshwater. An example of control of slime deposits on condenser tubes at a marine power station is presented in Figure 3.25. As this product also has anticorrosion and anti-scaling properties, the treatment procedure is generally intermittent, intended to renew the film on the surfaces to be protected, but periodic treatments can be more effective on macrofouling.

Three processes are involved in the disappearance of Mexel 432 in solution: an immediate demand wherein clays and humic acids play an important role, the effect of stirring the water and injecting air bubbles, and bacterial degradation in aerobic conditions. Isolated bacterial strains in the Seine degrade Mexel 432; one of these degrades $98 \%$ of the product in 10 days. A first-order kinetics equation fitted to the experimental results frequently shows disappearance of $60 \%$ of the product in one day in river water, independent of the immediate demand. This kinetics is close to that of bacterial biodegradation with the most efficient strain. (Allonier et al., 1997).

Information acquired regarding the toxic effects of the product on freshwater organisms shows rapid disappearance in natural waters of the product in its toxic form, and absence of detectable toxicity during its degradation (Arehmouch et al., 1998).

On the basis of the data now available, acceptable residual concentration thresholds are proposed to protect freshwater organisms exposed continuously to the product: be- tween 1 and $3 \mathrm{mg} / \mathrm{L}$ for brief releases (less than 1 hour) and $0.25 \mathrm{mg} / \mathrm{L}$ for continuous treatments lasting over 36 hours (Khalanski, 1997c).

\subsubsection{Some General conclusions on treatment of industrial cooling water systems with organics}

Organics present certain favourable characteristics for controlling fouling in industrial cooling systems.

They are easy to use. The minimum equipment required is an injection pump operated with a timer and an injection device which also mixes the product; this can sometimes be done by the pump used for circulating water in the system.

Generally, they have a wide spectrum of action on microfouling and macrofouling, depending on the selected procedure : periodic or intermittent treatments. Some, as can be demonstrated with a filming product, have also anti-corrosion and anti-scaling properties.

The cost of treatments with organic compounds depends on the protocol adopted, as well as on other factors such as the quality of the water to be treated and the characteristics of the target system. The most unfavourable conditions are found when the target species have a lengthy period of larval settlement and a high growth rate, and when particulate matter and colloids consume a large proportion of the product. 


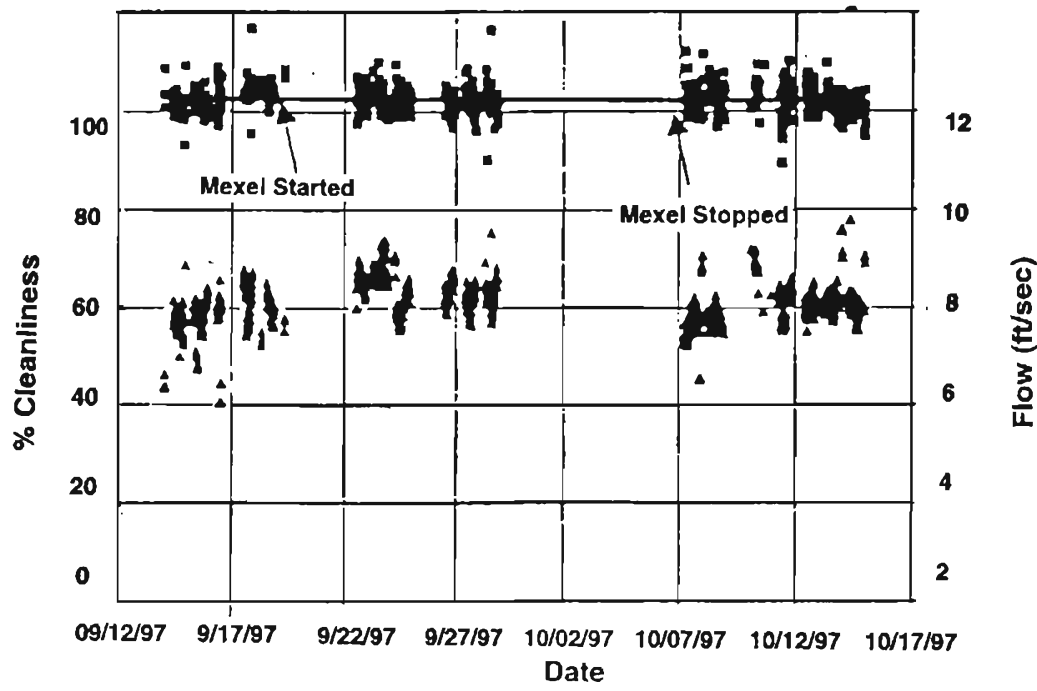

TUBE MEXEL 432 TREATED

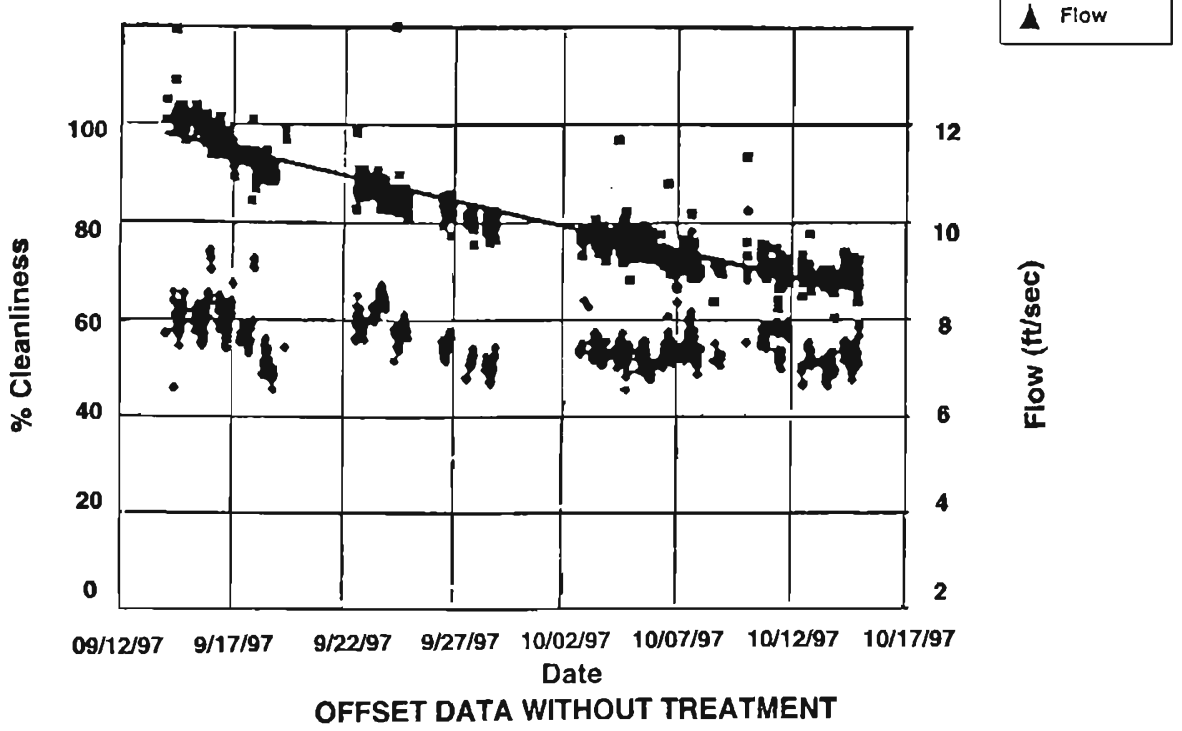

Fig. 3.25. - Evolution of the cleanness of condenser tubes treated by a filming agent (Mexel 432) at a marine power station. Procedure: First injection at $4 \mathrm{mg} / \mathrm{L}$ then $4 \mathrm{mg} / \mathrm{L}$ once a day for 15 minutes. (Garey \& Gross, 1997). 
With respect to environmental acceptability for the products most commonly used in cooling systems, they disappear more or less rapidly in waters due to adsorption on suspended solids and colloids and by degradation involving no production of toxic by-products. Toxicity data on aquatic organisms exist which are consistent with this. For some QACs and filming agents, it is possible to eliminate toxic residuals at the outlet of the cooling systems by adding clay, which adsorbs the toxic agents. On the other hand, dilution of treated water with non-treated water inside the cooling system can eliminate any residual toxicity at the outlet of the system.

In the United States, the EPA authorizes use of QACs in continental waters under two conditions (Schroening et al., 1995) :

- mixing : discharge in the river in which the release is made must be sufficiently high, which can preclude use of this kind of treatment in open circuit hydroelectric plants;

- detoxification of the effluent by the addition of clay prior to release, for products adsorbed on suspended matter.

Even despite this, environmental regulatory agencies are often opposed to the use of organics as an alternative to chlorination; they tend to prefer physical methods which are thought to eliminate the risk of chemical inputs in the aquatic environment. More and more, it will be necessary to prove that the choice of a given method can be justified by a "BATNEC Approach". In this sense, when physical methods are not applicable or ineffective, certain organic products can provide the best available solution.

\subsubsection{Metals}

The efficacy of coatings containing leachable copper and zinc was discussed earlier (3.6.). There is no doubt that these metals have a toxic effect in their immediate vicinity. Devices have been developed to treat water circuits by producing metals in soluble form. These metals must remain in the water in a concentration which is toxic for the target organisms.

Most of the commercially available devices are electrolysis systems; the metals are generated by dissolving copper anodes with which, in certain cases, aluminum anodes have been associated. Aluminum is claimed to produce a floc of aluminum hydroxide, forming a complex with copper $\left(\mathrm{Cu}(\mathrm{OH})_{3} \mathrm{Cu}_{2} \mathrm{O}\right)$ which has a coating effect. Davenport et al. (1986) have shown that this floc only inhibits larval settlement in low flow areas where it forms a physical choking barrier, but it is not toxic for biofouling organisms.

This technique has been used in seawater since the Sixties, essentially in boat cooling systems, but also in cooling systems in factories on land. A copper ion concentration of several dozen $\mathrm{mg} / \mathrm{L}$ is required to eliminate marine biofouling : the long-term toxic concentration for the marine mussel is between $10 \mathrm{mg} / \mathrm{L}$ and $20 \mathrm{mg} / \mathrm{L}$ (Davenport et al., 1986). 
To treat high flows, the electrodes must be dimensioned accordingly; it is poor dimensioning which is responsible for the failure of these processes (Mussali, 1988). In one device proven effective in circuits with flow up to 3.3 $\mathrm{m}^{3} / \mathrm{s}$, the electrodes are composed of a cathode with copper and aluminum anodes which deliver copper in a concentration of $25 \mathrm{mg} / \mathrm{L}$ in the circuit. The current varies between $10 \mathrm{~A}$ and $250 \mathrm{~A}$ in the largest installations. Other systems, also effective against marine biofouling, maintain a copper concentration which varies between $13 \mathrm{mg} / \mathrm{L}$ and $54 \mathrm{mg} / \mathrm{L}$ (Roch et al., 1986).

In addition to the investment cost, the cathodes must be periodically changed : consumption of copper can be up to $65 \mathrm{~kg}$ per month, for a treated flow of $1 \mathrm{~m}^{3} / \mathrm{s}$. The use of this type of process for direct cooling systems (a few dozen $\mathrm{m}^{3} / \mathrm{s}$ to a few hundred $\mathrm{m}^{3} / \mathrm{s}$ ) would add several dozen tons of metal per year to the coastal environment. Unlike paints, for which leaching generates but little additional copper, electrolysis processes are not environmentally acceptable for direct cooling systems.

In recirculating cooling systems, with lower flow rates ( 3 to $8 \mathrm{~m}^{3} / \mathrm{s}$ ), metal releases are lower but nonetheless represent an important occasional source in the river. The toxicity of copper in freshwater depends to a large degree on the hardness of the water. The European Union Directive regarding water quality requirements to protect the fish populations sets concentrations as a function of water hardness (Table 3.39).
Table 3.39. - Guideline soluble copper concentrations to protect freshwater fish populations depending on the hardness of the water (EEC 78/659).

\begin{tabular}{c:c}
$\begin{array}{c}\text { Total Hardness } \\
(\mathrm{mg} / \mathrm{L} \mathrm{CaCO3)})\end{array}$ & $\begin{array}{c}\text { Soluble Copper } \\
(\mu \mathrm{g} / \mathrm{L})\end{array}$ \\
\hline 10 & 5 \\
\hline 50 & 22 \\
\hline 100 & 40 \\
\hline 300 & 112 \\
\hline
\end{tabular}

In water with a low mineral content, copper is toxic in low concentrations for certain invertebrates and for salmonids. It is thus clear that water quality determines the amount of copper needed to eliminate invertebrates in freshwater : a few $\mathrm{mg} / \mathrm{L}$ in soft water at $25 \mathrm{mg} / \mathrm{L} \mathrm{CaCO}_{3}$, as opposed to hundreds of $\mathrm{mg} / \mathrm{L}$ in hard waters, with $300 \mathrm{mg} / \mathrm{L} \mathrm{CaCO}_{3}$ (Kelly, 1988).

The use of copper to combat freshwater biofouling in cooling systems with high flows therefore poses a problem, though tests are being conducted to eliminate the Zebra mussel with a concentration of around $10 \mathrm{mg} / \mathrm{L}$ (Blume et al., 1994).

A biocide combining hydrogen peroxide and silver is used in closed systems for sterilization in the food industry, and poses no particular problems for this type of application. On the other hand, treatment of direct cooling systems and even of recirculating cooling systems, with releases into the environment, is environmentally questionable due to the addition of non-negligible amounts of metal.

Lastly, in this succinct overview, we should list the products which are probably, among those commercially 
Table 3.40. - Effects of tributyltin acetate on embryogenesis and larval development of the oyster Crassostrea gigas (His, 1995).

TBT acetate $(\mu g / L)$

$\begin{array}{cc}100 & \text { Inhibition of fertilization } \\ 50 & \text { Inhibition of cleavage of eggs } \\ 10 & \text { No development of trochophor } \\ 3 \text { to } 5 & \text { No D larvae, all trochophores } \\ 1 & \text { Abnormal D larvae, no surviva } \\ 0.5 & \text { No survival beyond day } 8 \\ 0.2 & \text { No survival by day } 12 \\ 0.1 & \text { Sub-total mortality on day } 12 \\ 0.05 & \text { High mortality on day } 10 \\ 0.02 & \text { No significant effect observed }\end{array}$

available, the most effective against all types of biofouling : the organotins. Twenty years ago, Tributyl tin oxide (TBTO) was successfully tested on marine power stations in Italy, in the Netherlands, and probably in other European countries. It was found effective against bacterial slime and all kinds of macro-biofouling organisms in very low concentrations $(7.5 \mathrm{mg} / \mathrm{L}$ in TBTO or $50 \mathrm{mg} / \mathrm{L}$ in commercial products).

However, the release of small amounts of organotin from the antifouling paints on pleasure boats was found responsible for a drastic reduction of oyster reproduction in the Bassin d'Arcachon on the southwest coast of France from 1976 to 1981. The extreme toxicity of TBT has been demonstrated on oyster larvae (Table 3.40) and adults (Alzieu et al., 1980, His, 1995), on plankton crustaceans, and on various invertebrates. Sexual disturbances (imposex) are found in marine molluscs with concentrations as low as $0.5 \mathrm{mg} / \mathrm{L}$ (Hall, 1988). Because of their toxicity, organotins are no longer used in cooling water circuits in European Union countries and their use in anti-fouling paints has been restricted by regulations.

\subsubsection{Oxygen deprivation}

Tolerance of the Asian clam Corbicula fluminea and the Zebra mussel Dreissena polymorpha to chronic hypoxia has been investigated by Johnson \& McMahon (1997) and shown to be dependent on water temperature. On the zebra mussel, at the $5 \%$ dissolved-oxygen saturation level, the time required to kill $50 \%$ of the tested animals (LT50) is 44 days at $5{ }^{\circ} \mathrm{C}, 25$ days at $15^{\circ} \mathrm{C}$ and only 5 days at $25^{\circ} \mathrm{C}$. On the Asian clam, the LT50 is 20 days at $5^{\circ} \mathrm{C}$ and 6 days at $25^{\circ} \mathrm{C}$ (Table 3.41 ).

Oxygen deprivation was tested in France on an intake pipe at the Méry- 
Table 3.41. - Lethal time (LT50) for Corbicula fluminea and Dreissena polymorpha depending on dissolved oxygen saturation (DO\%) and water temperature (Johnson \& McMahon, 1997).

\begin{tabular}{|c|c|c|c|c|c|c|}
\hline & \multicolumn{3}{|c|}{ Corbicula fluminea } & \multicolumn{3}{|c|}{ Dreissena polymorpha } \\
\hline $\begin{array}{c}\text { saturation } \\
(\%)\end{array}$ & $25^{\circ} \mathrm{C} \mathrm{LT}_{50}$ & $15^{\circ} \mathrm{C} \mathrm{LT}$ so & $5^{\circ} \mathrm{C} \mathrm{LT} 50$ & $25^{\circ} \mathrm{C} \mathrm{LT}_{50}$ & $15^{\circ} \mathrm{C} \mathrm{LT} 50$ & $25^{\circ} \mathrm{C} \mathrm{LT} 50$ \\
\hline 5.0 & 6 days & 20 days & 20 days & 5 days & 25 days & 44 days \\
\hline 7.5 & 9 days & 16 days & & 9 days & $>30$ days & \\
\hline 10.0 & 9 days & . & & 9 days & & \\
\hline 15.0 & & & & $>30$ days & & \\
\hline
\end{tabular}

sur-Oise drinking water processing plant. The test consisted in isolating the pipe and injecting sodium bisulfite to consume dissolved oxygen. The procedure was not effective: it took two weeks to consume the oxygen in the long pipe, where mixing of the reductive solution was difficult, and some of the mussels survived the treatment.

Hypoxia-based control methods require very low oxygen concentrations and sustained application at water temperatures lower than $20^{\circ} \mathrm{C}$. They are only potentially applicable to stagnant or semi-stagnant waters.

\subsubsection{Potassium ions toxicity to Zebra mussels}

Since the experimental work of Fisher et al. (1991) potassium ion is known to be a specific toxic agent for Zebra mussels: $\mathrm{LC}_{50}, 24 \mathrm{~h}$ is 138 $\mathrm{mg} / \mathrm{L}$ at $20^{\circ} \mathrm{C}$.

Total mortality for 7-11 mm Dreissena polymorpha in the Moselle river was achieved for 48 hours at 600 $\mathrm{mg} / \mathrm{L}$ of $\mathrm{KCl}(\mathrm{K}=314 \mathrm{mg} / \mathrm{L})$ (Khalanski, 1993). These high concentrations are not compatible with treatment of large cooling water systems but can be a convenient solution for circuits containing stagnant or semi-stagnant waters, such as fire protection systems. At Bruce B nuclear power station, operated by Ontario Hydro, treatment with commercial potash, at potassium concentration of $100 \mathrm{mg} / \mathrm{L}$ for some days was successfully applied to a fire protection system (Lewis et al., 1997b).

\subsection{OTHER PHYSICAL METHODS}

\subsubsection{Ultraviolet (UV) light}

UV light $(1 \leq 253.7 \mathrm{~nm})$ is capable of killing bacteria in the bulk water of circulating water systems (Gilpin et al., 1985) and is now commonly used by hospitals and food industries for 
water sterilization purposes. It has become a popular disinfecting agent for small volumes of drinking water and recreational pools on a small scale. More recently, the ability of some equipment to treat large volumes of water has led to the promotion of UV disinfection of different types of water and some applications have appeared in the field of antifouling treatments.

One important limiting factor for the use of UV light on natural raw waters is the adverse effect of turbidity, suspended solids and dissolved organic substances on UV absorbance. It is recommended to filter the wastewaters prior to treatment with UV light to eliminate coliform bacteria (Darby et al., 1993).

\subsubsection{Antifouling treatments on fresh water}

Experiments were performed by Ontario Hydro on freshwater exposed for 40 seconds to a UV light (flux of $24 \mathrm{~W} / \mathrm{cm}^{2}$ at the lamp surface) produced by a germicidal system to test the effect on Zebra mussel settlements. No larval settlement was observed, but mussels of $2 \mathrm{~mm}$ to $5 \mathrm{~mm}$ in length were occasionally observed; these translocators are protected by their shell against UV light (Ewans et al., 1992).

Ontario Hydro has tested a UV device at the Bruce $B$ nuclear power station. Two banks of UV lights were installed on the cooling water inlet gallery for a service water circuit. This power station is located on the shore of Lake Huron, whose water is very clear. The racks of lamps were located downstream of the traveling screen. Initial results are promising: the UV treatment killed about $85 \%$ of the Zebra mussel veligers. Trials were in progress in 1997 to verify the effect of UV light on bacterial slime and Zebra mussel development in the treated circuit.

Ontario Hydro tests suggest that UV light may be effective in preventing the settlement of macrofouling spat, but that it cannot prevent settlement of older stages entering the CWS.

\subsubsection{Antifouling treatments on seawater}

In Japan, UV irradiation is considered as a potential alternative to seawater chlorination (Hori et al., 1993). Laboratory experiments on nauplii larvae of the barnacle Chthamalus spp. (Hori et al., 1990), led to four important conclusions :

$\left.1^{\circ}\right)$ The larval mortality depends on the UV dosage: energy density $\left(\mathrm{mW} / \mathrm{cm}^{2}\right) \times$ exposure time (s). All irradiated larvae are killed within 71 to 75 hours at a UV intensity of 5.6 $\mathrm{mW} / \mathrm{cm}^{2}$ for a minimum exposure of 2 minutes; 4 minutes of exposure are needed at $3.0 \mathrm{~mW} / \mathrm{cm}^{2}$. The effective dosage is thus $672 \mathrm{~mW} . \mathrm{s} / \mathrm{cm}^{2}$.

$2^{\circ}$ ) The lethal effect of UV irradiation is felt in around 3 days.

$3^{\circ}$ ) Irradiated nauplii lose their swimming capacity at sub-lethal dosages: $93 \%$ of larvae exposed to 85 $\mathrm{mW} . \mathrm{s} / \mathrm{cm}^{2}$ are unable to swim after 72 hours. 


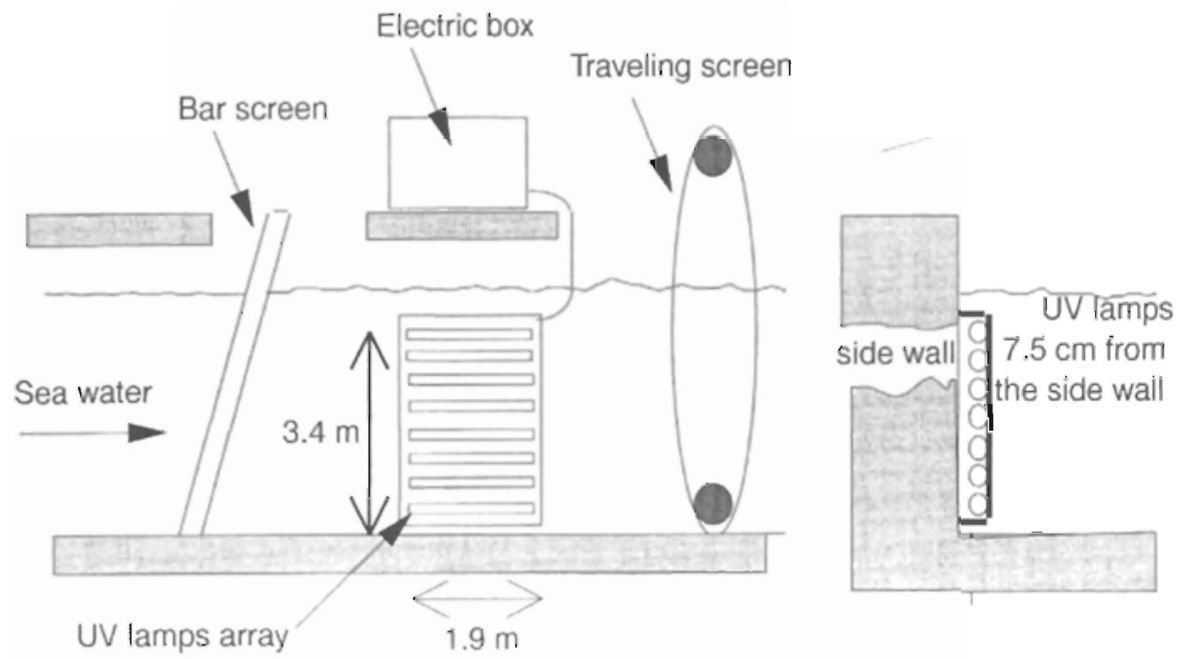

Fig. 3.26. - Intake conduit of the Isogo power station (Japan), equiped with an UV irradition system. Redrawn from Hori et al. (1993).

$\left.4^{\circ}\right)$ Exuvia production is inhibited at a dosage of $45 \mathrm{~mW} . \mathrm{s} / \mathrm{cm}^{2}$ and there is no production of exuvia at 246 $\mathrm{mW} . \mathrm{s} / \mathrm{cm}^{2}$.

On cypris larvae, the only barnacle larval stage which can settle, settlement is reduced by $40 \%$ at 17 $\mathrm{mW} . \mathrm{s} / \mathrm{cm}^{2}$ and by $96.8 \%$ at 30 $\mathrm{mW} . \mathrm{s} / \mathrm{cm}^{2}$ (Hori et al., 1993).

Based on these promising experimental results, a UV treatment system was designed and installed at the Isogo power station. This is a $530-\mathrm{Mw}$ marine power station operated by Electric Power Development Co. Ltd. It is located near the mouth of Tokyo Bay (Hori et al., 1993). The irradiation system consists in a panel of lowpressure UV lamps (160 W) attached to the side wall at one of the four intake conduits of the power station, in the area between the bar screen and the traveling screen (Fig. 3.26); the water flow in this conduit is $4.6 \mathrm{~m}^{3} / \mathrm{s}$. Lamps are positioned $75 \mathrm{~mm}$ from the wall and the UV dosage is $17 \mathrm{~W} . \mathrm{s} / \mathrm{cm}^{2}$ at a distance of $150 \mathrm{~mm}$ from the wall. Severe problems occurred with water leakages into the UV lamps due to imperfect sealing, and the initial design was changed to prevent leakage. The target efficiency for the system was some $50 \%$ reduction in settlement. The results of the field test showed a global reduction of $59 \%$ of macro-biofouling in wet weight, mainly due to the decreased mussel and tube worm settlement (Kawabe, 1997).

\subsubsection{Benefits and drawbacks of UV antifouling technology}

The great benefit of UV light is the absence of chemical discharge and the relatively low energy consumption.

The antifouling action of UV light is preventive; it may kill plankton organisms in the bulk water (bacteria, 
larvae), but it can not exert a direct effect on the sessile populations present on the heat exchanger surfaces and other relevant surfaces in the CWS. Furthermore, a certain minimum clarity of the water is needed for sufficient penetration of the UV light.

In spite of these drawbacks, UV light may be used as a supplemental method in biofouling control.

Feedback must nonetheless be acquired on industrial site tests in order to define the fields of application of the technique and provide needed information on the investment and maintenance costs of the treatment systems.

\subsubsection{Electric fields}

The use of electric fields as an antifouling method involves preventing the settlement of larvae due to the effect of high-energy electric shocks or low-level currents. Theoretically, the biological effect, and consequently the efficiency, is proportional to the square of the electric field intensity in $\mathrm{V} / \mathrm{cm}$. This requires that the water pass between plate electrodes close enough to each other to achieve the optimum intensity.

The energy consumption also depends on the salt content of the water : it is inversely proportional to the water resistivity. In order to minimize the energy consumption of this type of system, experiments have been conducted on pulsed fields : shocks of 0.77 microseconds ( $\mu$ s) with an inten- sity in the range of 1 to $10 \mathrm{kV} / \mathrm{cm}$ can halt larval settlement. In seawater, the barnacle larva does not settle with $0.77 \mu \mathrm{s}$ shocks at $7 \mathrm{kV} / \mathrm{cm}$, and a more than $90 \%$ reduction in settlement was observed at an intensity of $3 \mathrm{kV} / \mathrm{cm}$. A field study performed in river water at Norfolk, Va, USA, showed that pulses of $0.77 \mu$ s at 6.5 $\mathrm{kV} / \mathrm{cm}$ can protect pipes against biofouling. The energy consumption in this trial was about $1 \mathrm{MW}$ to treat a flow of $2 \mathrm{~m}^{3} / \mathrm{s}$, but better efficiencies are expected in the future (Schoenbach et al., 1997).

Aside from the question of electricity consumption, use of this method on large volumes of relatively fastflowing raw waters can not be envisaged until industrial experience is acquired. Among other things, the long-term resistance of a device containing electrodes must be determined.

Low-level electric fields could also be effective against settlement of $\mathrm{Ze}$ bra mussels, as shown by promising experiments conducted at the Nanticoke thermal power station operated by Ontario Hydro. Panels with electrodes were placed $5 \mathrm{~cm}$ apart and electrified with currents of 16 to $20 \mathrm{~V}$, 1.0 to $1.9 \mathrm{~A}$, generating a field intensity of 3 to $10 \mathrm{~V} / \mathrm{cm}$ (Fears \& Mackie, 1997).

\section{Cathodic protection}

In the former Soviet Union, cathodic protection systems were used to prevent Zebra mussel settlement, with higher current densities than required for the anti-corrosion effect : 50 to 75 
$\mathrm{mA} / \mathrm{ft}^{2}$. Studies were carried out in the 90 s in the U.S. and Canada in order to test the effectiveness of cathodic protection with currents in the range of 2 to $10 \mathrm{~mA} / \mathrm{ft}^{2}$ (Lewis \& Pawson, 1993). Larval settlement was greatly reduced at current densities of 6 to 9 $\mathrm{mA} / \mathrm{ft}^{2}$ (Table 3.42).

Hydro Quebec equipped a large sluice gate with special anodes $(\mathrm{Cu}$, $\mathrm{Ni}, \mathrm{Pt}$ ) electrified at current densities of approximately $13 \mathrm{~mA} / \mathrm{ft}^{2}$. After 5 months, $70 \%$ of the Zebra mussels settled on steel and concrete walls were removed and probably killed (Serli et al., 1994).

Ontario Hydro tested cathodic protection to control Zebra mussels on the concrete walls of a pump well at the Bruce $B$ power station (Lewis et al., 1997a). Anode mesh panels were fixed on the walls of the well between trash racks at the inlet and the traveling screens. After two years, a reduction of $90 \%$ of the older age classes $(0.5 \mathrm{~cm}$ to $2.0 \mathrm{~cm})$ was observed in comparison with the control wells. The

Table 3.42. - Results of two experiments on cathodic protection against zebra mussel settlement, at various current densities (Lewis \& Pawson, 1993).

\begin{tabular}{|c|c|c|}
\hline $\begin{array}{l}\text { Current } \\
\text { density }\end{array}$ & $\begin{array}{l}\text { Larval } \\
\text { settlement }\end{array}$ & Corrosion \\
\hline Control $(0)$ & $137 / \mathrm{m}^{2}$ & Yes \\
\hline $2 \mathrm{~mA} / \mathrm{tt}^{2}$ & $156 / \mathrm{m}^{2}$ & some \\
\hline $4 \mathrm{~mA} / \mathrm{ft}^{2}$ & $80 / \mathrm{m}^{2}$ & No \\
\hline $5 \mathrm{~mA} / \mathrm{ft}^{2}$ & $32 / \mathrm{m}^{2}$ & No \\
\hline Control $(0)$ & $29 / \mathrm{m}^{2}$ & Yes \\
\hline $6 \mathrm{~mA} / \mathrm{ft}^{2}$ & $2.6 / \mathrm{m}^{2}$ & No \\
\hline $9 \mathrm{~mA} / \mathrm{ft}^{2}$ & $2.6 / \mathrm{m}^{2}$ & No \\
\hline
\end{tabular}

dry weight of the remaining mussels was also less than that of the control. This experiment led to the following conclusion: current densities of less than $10 \mathrm{~mA} / \mathrm{ft}^{2}$ and voltage $<40 \mathrm{~V}$ are effective in controlling the development of Zebra mussels on steel and concrete walls. A cathodic protection system has also been installed in some basins of the intake structure at the Darlington nuclear power station operated by Ontario Hydro.

\subsubsection{Magnetic fields}

Magnetic systems are known to control scaling in pipes; this would suggest a biological effect on calcium metabolism, which could disturb and even stop shell growth in molluscs. To date, there is no evidence of such an effect. Experimental trials on river water passing through cells with magnets have been conducted at a Rochester Gas \& Electric Corporation testing station. After 99 days, the Zebra mussels on the control and test bioboxes showed no significant differences in terms of mortality, shell length or calcium-magnesium content in soft tissues (Smythe et al., 1997).

\subsubsection{Acoustic energy}

Ontario Hydro conducted experiments on high acoustic energy (173 to $199 \mathrm{~dB}$ ), using juvenile mussels to test their attachment on the wall of an aluminum pipe (Ewans et al., 1992). During the 4-hour treatment, 
the most effective frequency was in the range of 8 to $16 \mathrm{kHz}(100 \%$ mussels not attached).

Pulses with a high acoustic energy can remove the biofouling cover from concrete walls and avoid mechanical cleaning in pipes, basins and wells fed with raw water. A submersible unit has been specifically designed for this purpose (Bryden, 1997). It is equipped with a sparker unit delivering 5-kilojoule pulses every 45 seconds. This device generates a sound intensity of 200 plus dB. It was tested successfully for 6 months against Zebra mussels and biofilm at municipal water treatment facilities.

\subsection{BIOLOGICAL CONTROL}

The principle of biological control is to combat a targeted species by favouring the development of its natural enemies. This involves a wide variety of biological and ecological processes: pathogens, parasites, predators and competitors can reduce populations of biofouling species. The recent introduction of Zebra mussels in North America has prompted numerous studies in this field.

Natural aquatic bacteria capable of killing Zebra mussels have been selected from stressed mussels; some lead to $100 \%$ mortality in 5 days. Toxins (polysaccharides and proteins) have been extracted from these strains and have been tested with success in organic coatings (Gu \& Mitchell, 1997).
The association between a parasite and a host is the result of a co-evolution process, thus parasitic species are frequently strictly host-specific. Preliminary research has shown that some ciliates parasiting the digestive gland of Dreissena polymorpha could have deleterious effects (Molloy et al., 1997)

Coatings based on naturally-produced anti-foulants and enzymes have been reviewed by Berger et al., 1994 . To date, no commercial products have resulted from this.

Chemicals are capable of repelling settled organisms; thus xanthatin, isolated from leaves of Xanthium strumarium, has a repellent activity against the blue mussel - Mytilus edulis (Harada et al., 1985) and diphenylamine was found to be an excellent repelling agent for zebra mussels, and phenols extracted from wood are also efficient as repellents (Gu \& Mitchell, 1997).

Competition for space is important for settled organisms, and it has been observed that Zebra mussels populations have declined in some parts of the Rhine where an amphipod crustacean (Corophium curvispinum) has recently massively developed, though according to observations in 19961997, the two species co-exist in the Moselle. Zebra mussels are not found on the sponge Spongilla, but the latter has a low rate of coverage of hard substrates. Bryozoan Lophopodella carteri reduces the settlement of zebra mussels in the Great Lakes, according to Lauer et al. (1997). 
It is unlikely that one species can be efficiently controlled by occupation of all available space by another species. The replacing species would then be at least as undesirable as the species replaced. It is, on the contrary, extremely frequent to find several species co-existing on the walls of cooling water systems :

- in seawater, hydroids and barnacles, on which marine mussels settle (Mytilus edulis),

- in freshwater, a layer of hydroids (Cordylophora caspia) on which Zebra mussels settle.

Competition for food is equally decisive in development of biofouling species. Most consume particles in suspension, but any excessive development is merely due to better use of food resources than that of their competitors. The same is true of predators: if one species has developed extensively, this implies that it is but little consumed by predators.

Finally, it is necessary to take the specificities of the circuits themselves into account; they are extremely favourable to biofouling and the basic ecological factors (water velocity, availability of food, absence of predators) are equally favourable to biofouling development. For all these reasons, ecological factors involving competition and predation do not apply to cooling water systems, though they often play an important role in natural systems. In northeast France, the Zebra mussel is controlled in many lakes and reservoirs by diving ducks which limit mussel development, whereas thermal power plant circuits are overrun by this species.

Some biological control methods, mainly those involving pathogens and parasites, offer interesting prospects for the future but are still in the experimental phase and cannot yet be used for industrial applications. If effective methods were available, they would still need to be proven harmless to aquatic fauna. The conclusion proposed by Claudi \& Mackie (1993) remains true today: "This type of research requires a long-term commitment and usable products are probably years away".

\subsection{BIOLOGICAL MONITORING}

\subsubsection{Macrobiofouling}

Long-term monitoring of biofouling at industrial sites provides information on the composition and abundance of populations settled in the circuits. Sometimes major fluctuations are found with invasive species over the years. These changes are revealed by sampling at selected points in the cooling system (water intake structure, screens, pipes, galleries, basins, heat exchangers) during scheduled shutdowns, particularly for cleaning (Khalanski, 1997a, b).

Long-term monitoring enables detection of the appearance of new invasive species, and can be performed outside the cooling system, in the river or on the sea coast. In France, 


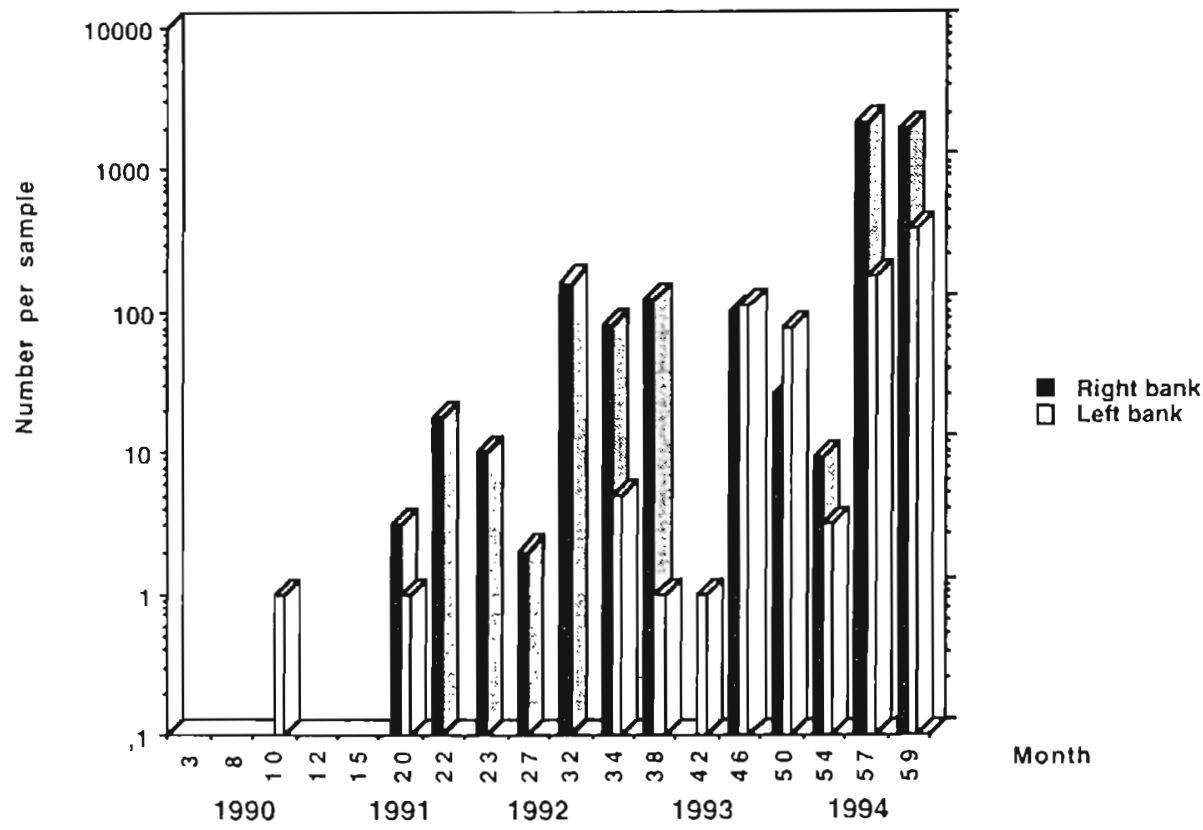

Fig. 3.27. - Abundance of the Asiatic clam (Corbicula sp.) in the river Rhone from 1990 to 1994 in the vicinity of the Le Bugcy nuclear power station (CEMAGREF Data. Khalanski, 1997a).

ecological monitoring of the aquatic environment around nuclear power plants began in the early $80 \mathrm{~s}$. This program revealed the appearance of invasive species like the Asian clam in the Rhône (Fig. 3.27) and that of the amphipod crustacean Corophium curvispinum in the Moselle.

Schedules for treatment are defined on the basis of the periods of settlement of the main fouling larvae and the growth rate of organisms in the circuits to be protected. For this, it is indispensable to collect data inside the circuits, given that the water velocity and temperature conditions are highly specific to location in the circuit. In particular, it should be remembered that the growth rate of organisms in the natural environment is generally slower than for populations settled in plant circuits. If the necessary data is available, a growth model applicable to the circuits can be developed (Moreteau \& Khalanski, 1994).

During the critical period in the year, corresponding to settlement and optimum growth of biofouling species, biomonitors can be installed to provide the data needed for optimization of the treatment in light of the specificities of any given year. This type of monitoring is especially helpful in the case of periodic treatments and "end of season" treatments.

In the Netherlands, KEMA has developed a "mussel monitor" consisting in a closed cylindrical PVC container 
in which the water flows from top to bottom (Jenner, 1983b). This monitor can be used to detect spat settlement of bivalves such as Mytilus edulis, Dreissena polymorpha and Mytilopsis leucophaeata. It is installed at power stations during chlorination, and is used to follow the course of treatment and evaluate its success (Jenner \& Janssen-Mommen, 1993).

In 1998, a new design of a biofouling monitor was tested at several power stations. This design was the collaborative result of Fawley $A R L$ and KEMA. Main feature is the choice for flow direction which is now bottomtop. The design allows operators to sample the monitor during operation. Silting-up of the monitor is solved by building in a sediment trap. The monitor can be equipped with extra analysers for $\mathrm{pH}$, dissolved oxygen, turbidity and temperature. For mussel spat detection a non-woven $3 \mathrm{M}$ mat is used which is the absolute favourite settling material for mussels.

ENEL uses a simple monitoring procedure to provide power station operators with an indication of the periods when chlorination can be avoided in once-through cooling seawater systems. Plates are immersed monthly near the intake and observed under a dissecting microscope in order to count the surface units $\left(1 \mathrm{~cm}^{2}\right)$ colonized by fouling organisms. This value is converted into conventional percentage of total cover. During spring, plates are also observed fortnightly, for more precise determination of the start of settlement. Figure 3.28 gives the monitoring results from a two-year survey in a Northern Adriatic power station, with an indication for suspension of chlorination for 5 months.

Biofouling has also been monitored at the Vandellos nuclear power station (operated by UNESA on the Mediterranean coast of Spain) to determine the periods of chlorination.

ENEL has produced a manual for monitoring macrofouling settlement periods and optimizing chlorination in thermoelectric power plants (ENELCRAM, 1996).

A bibliographic survey on Mediterranean fouling has been published by Relini (1993) with references on earlier papers about fouling studies in power stations (Relini \& Romaiore, 1976; Relini \& Bianchi, 1979; Relini et al., 1980; Relini, 1984; Gitay \& Glazer, 1979; Glazer \& Gitay, 1988/89; Ambrogi, 1993.)

\subsubsection{Microbiofouling on line monitors}

Some monitoring devices which are able to detect biofilm growth through induced physical effects (changes in thermal conductivity or in the friction factor) are already available, but their sensitivity proved to be low during the crucial first phase of the biofilm build-up (Characklis, 1990). Such devices are generally able to signal the presence of biofilm when its thickness is more than $=30-40 \mu \mathrm{m}$. Furthermore, their use for driving the 


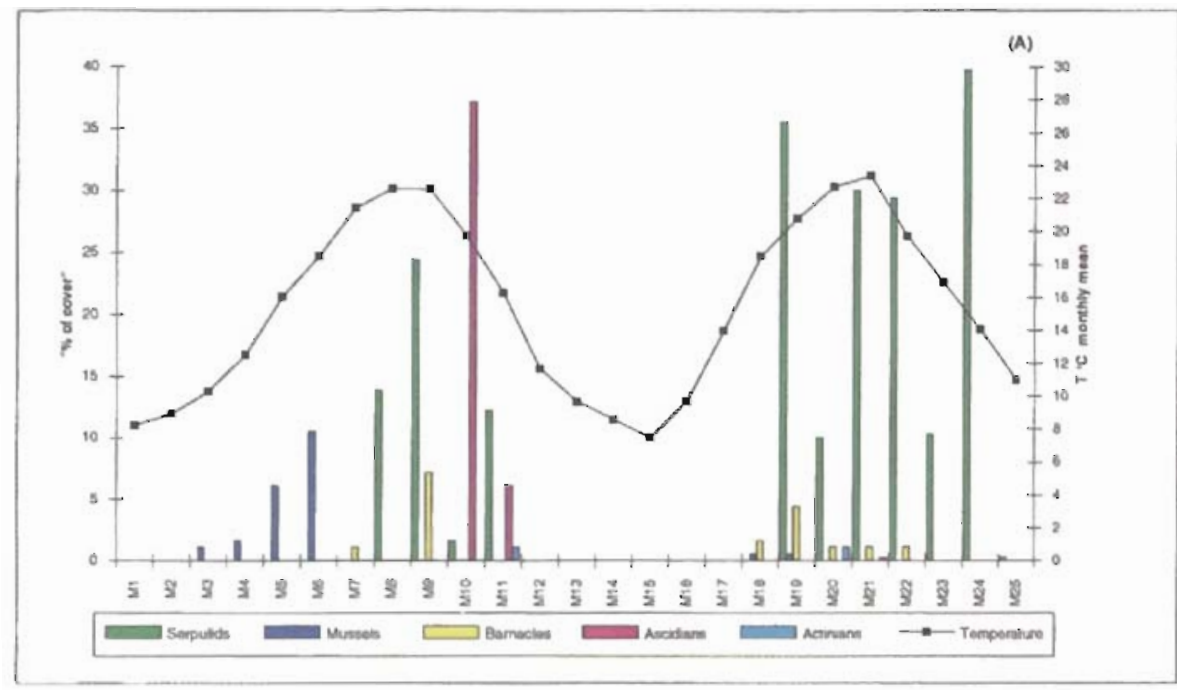

A - Percentage of cover of the main fouling groups of organism and monthly mean :emperature

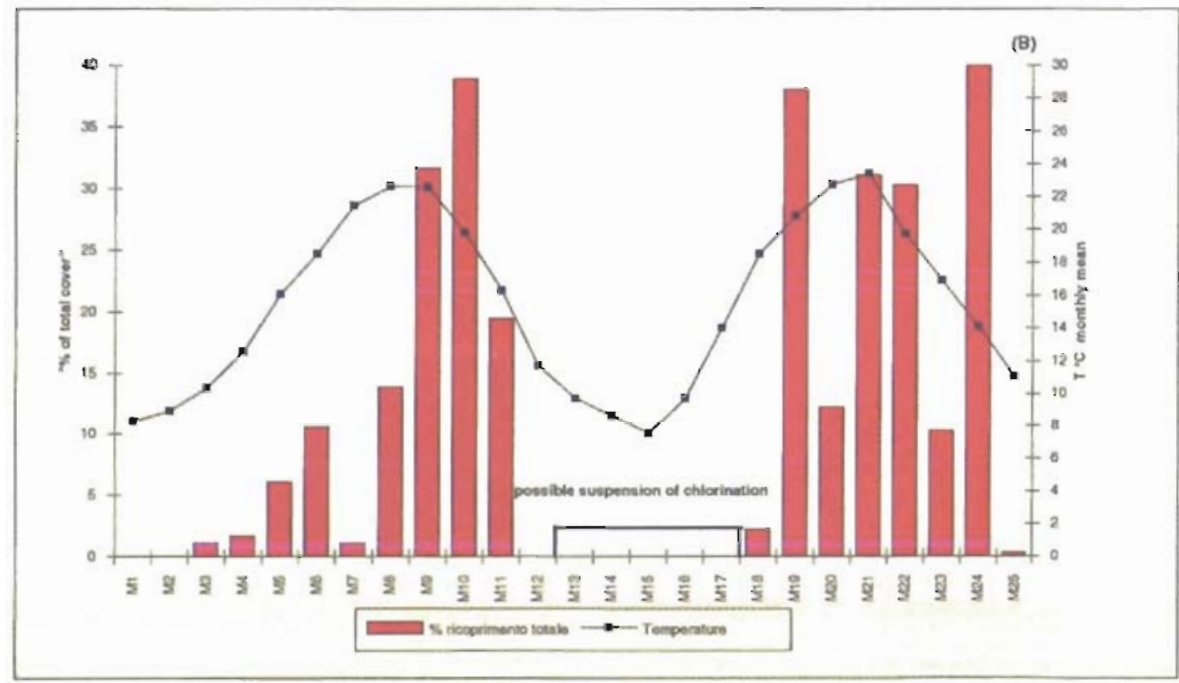

B - Percentage of total cover, montly mean temperature and period of possible suspension of chlorination (December 20, 1995 - May 15, 1996).

Fig. 3.28. - Monthly monitoring of fouling settlement at a power stations on Northern Adriatic, operated by ENEL, from M1 (Jan. 18-Feb. 15, 1995) to M25 (Dec. 11-Jan. 8, 1997).

A : Percentage of total cover on plates at the intake,

B : monthly mean temperature and period of possible suspension of chlorination (December 20 , 1995 - May 15, 1996). 
biocide programs, often, was not effective to keep satisfactory cleaning conditions in time. The experiments conducted by Lewis (1982) to monitor chlorination treatments employing sensors based on change in thermal conductivity : for example, pointed out that, at the end of a chlorination, if residual biofilm stays on the surfaces, the bacterial populations undergo a selection and the biofilm quickly grows and becomes more resistant to chlorine.

In order to produce biofilm sensors with higher sensitivity, during the last few years some innovative systems were set up. They are now available on the market (BIOX, BIO-George, Bioguard). These systems utilise electrochemical probes, inserted in an appropriate way into the cooling circuits. They permit the evaluation of the changes in kinetics of electrochemical processes occurring on metal surfaces and induced by bacterial settlement: through the continuous measurement of one or more electrochemical parameters (current density, potential difference, impedance, potential noise, polarisation resistance). It has been recently proven that the variation of some of these parameters is directly associated to the growth of the biofilm at the metal-sea water interface on an active-passive alloy (Chandrasekaram \& Dexter, 1993; Mollica et al., 1988).

Furthermore, it was shown (Mollica et al., 1996) that the galvanic current due to the coupling of a stainless steel electrode with a sacrificial anode is associated with the biofilm deve- lopment on the surface of the stainless steel electrode. Because the galvanic current reveals the changes of the cathodic properties on the stainless steel surface, i.e. the change in the oxygen reduction rate, the electrochemical effect of the biofilm growth is usually named "the oxygen reduction depolarisation" (Mollica et al., 1990). It was proven that the electrochemical sensors of biofilm growth are able to detect, in real time, the effect of antifouling procedures and are able to drive their application (Mollica \& Ventura, 1993a, b).

The main advantage of these devices, is that their use does not require personnel skilled in the biological or chemical field.

The lack in the control of sea water chlorine concentration can be the cause of ineffectiveness of the biocide treatments (Cristiani \& Bianchi, 1997). To control and optimise the dosage time and the concentration of sodium hypochlorite during the biocide treatments, ENEL has recently set up an innovative electrochemical system BIOX (available on the market by STELAR, italian factory) which allows the monitoring both of the biofilm growth and the evaluation of the changes in water TRO (total residual oxidant).

ENEL system (Cristiani et al., 1997) employs a new simplified version of electrochemical biofilm sensors. The response of the sensor permits to have a direct index of biofilm growth and the effective TRO on the sensor surface. The signal increases from $V_{0}$ to $V_{b}$ as a consequence of the highest cathodic efficiency in- 


\section{Biofilm and T.R.O. monitoring}

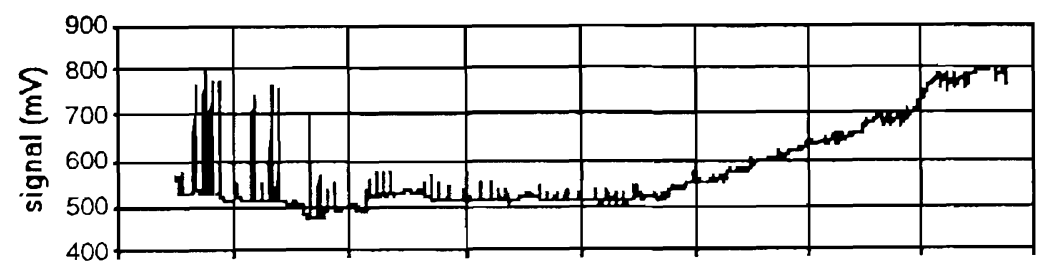

07/05/96 09/05/96 11/05/96 13/05/96 15/05/96 17/05/96 19/05/96 21/05/96 23/05/96

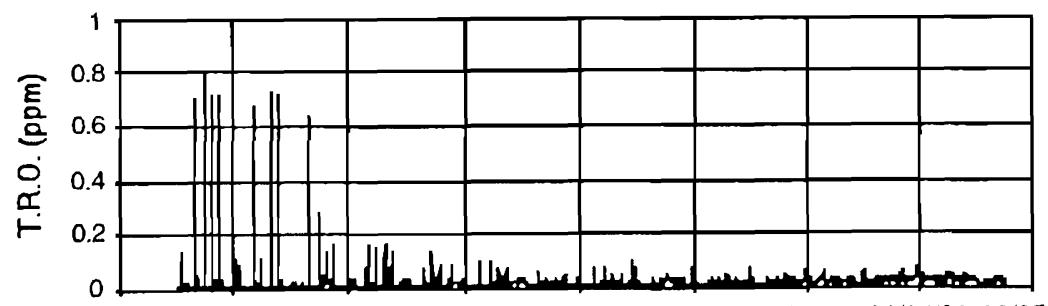

07/05/96 09/05/96 11/05/96 13/05/96 15/05/96 17/05/96 19/05/96 21/05/96 23/05/96

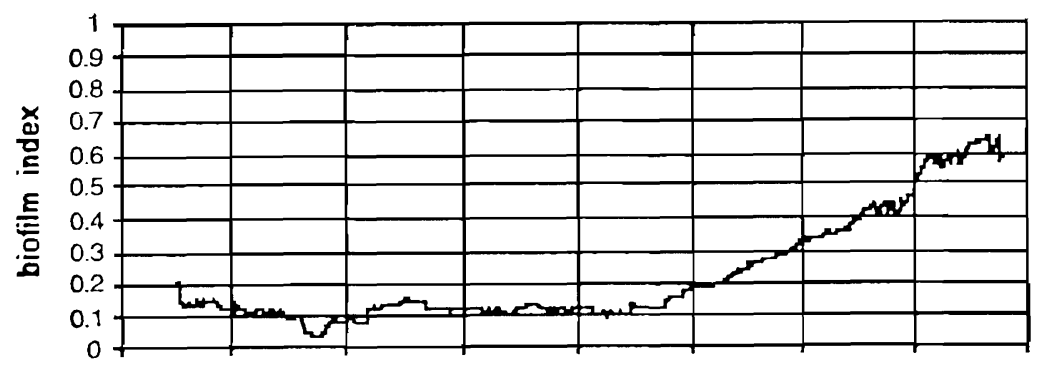

07/05/96 09/05/96 11/05/96 13/05/96 15/05/96 17/05/96 19/05/96 21/05/96 23/05/96

Fig. 3.29. - Lay-out of the biofilm and TRO electrochemical monitoring performed at Vado Ligure power plant during May 1996.

duced by biofilm growth on sensor and, of course, reverts to its initial value when the biofilm is completely destroyed by a suitable biocide addition to sea water. The cathodic efficiency induced by TRO on sensor has the same effect as the biofilm growth, but it is possible to discriminate the contribution of the two parameters.
At present, BIOX is used in some Italian power stations.

At the Vado Ligure power station, the chlorination program was performed in this way : 4 treatments per day, each lasting about half an hour, with "1 ppm (as TRO) of sodium hypochlorite The graphs (Fig. 3.29) show that the chlorination has been regularly 
carried out for one day only, after that TRO concentration decreased to very low values and, consequently, the biofilm started to growth.

The advantages expected from the introduction of such devices in all the plants that suffer from biofouling problems may be summarised as follows:

1. on-line information about biofouling growth on the water-side surface of the condenser tubes;

2. possibility of defining in real time the amount of sodium hypochlorite (or other oxidising agents) needed to obtain an effective concentration of TRO in the cooling water, thereby avoiding the need for carrying out continuous laboratory analyses for chlorine demand and concentration, and avoiding the use of other instruments which require careful and frequent maintenance;
3. optimisation of the consumption of sodium hypochlorite (or other oxidising agents), with respect to the treatment duration and concentration which are strictly necessary to inhibit the microbiofouling (the first stage of the biofouling) growth.

At KEMA, goods results have been obtained with the BioGeorge ${ }^{T M}$. The BioGeorge $^{\mathrm{TM}}$ online monitoring systern measures the electrochemical effect caused by the biofilm on metal surfaces. The probe of the system consists of two identical electrode systems. Increase of the "applied " or "generated" current indicates an increase of biofilm activity. Treatment of an existing biofilm shows a rapid return to the initial level. Summarised: the here presented systems are valuable tools for improvement of heat exchanger performance. 


\section{Regulatory context}

\subsection{INTRODUCTION}

Any fouling control procedure, involving the chemical treatment of cooling water, can result in a residual discharge of toxins to the environment. The costs of such procedures are genetally sufficient to provoke a common interest with the environmental protection need of minimizing these residuals, their presence being both wasteful and inefficient.

An antifouling agent which acts by inhibiting the normal development of aquatic organisms, as most in common use do, wil inevitably pose some degree of risk of environmental impact if discharged. To use such agents, it has become necessary to operators to delimit that risk, support the development of an informed understanding of the degree of tolerability of that risk, and minimize that risk where both practicable and needfull. Where the risk of any particular procedure has been found to be intolerable, that procedure has had to change.

The antifouling procedures in use today are those which present a ba- lance between operational practicability and the requirements of the environmental regulators, either stated or anticipated. Given that operational practicability tends (on the basis of accumulated and shared experience) towards an innate conservatism of practices, and that there is currently a rapid development in environmental regulation, the balance is probably altering. One function of this publication is to document the operator's understanding of current best practice in such a way that it can be considered in this context, in an informed manner, by both the operators themselves and the environmental regulators.

\subsection{BASIC PRINCIPLES OF THE EUROPEAN UNION (EU) LEGISLATION}

The reduction and control of water pollution and contamination have always been important priorities in the European Union's environment pro- 
gramme. EU controls on water pollution apply at several levels:

- at the level of the market, where specific products are controlled,

- at the level of industrial sector, where practices within a specific industry or type of industries are controlled,

- at the level of end-of-pipe discharges, where the release of specific dangerous substances is controlled; and

- at the level of environmental quality, where quality objectives are defined.

A variety of principles have become established in European law: perhaps the most fundamental are those of "sustainability", "polluter pays" and "subsidiarity".

There is now an increasing ackowledgement of the need to reconcile the needs for continued development with the long term goal of protecting the environment. A common working definition of sustainable development is "development which meets the needs of the present without compromising the ability of future generations to meet their their own needs" (Bruntland, 1987). Sustainable development was the central theme of the UN Conference on Environment and Development in Rio in June 1992 which resulted in Agenda 21, a programme to work towards a more sustainable future. The European Union's Fifth Action Programme "Towards Sustainability (1993-2000)" builds on earlier EU policies aimed at, amongst other things, maintaining and improving water quality by the prevention of pollution of groundwater and fresh and marine surface waters.

The sustainable development approach is contributing to pressure for a move away from the use of chemicals which are persistent or give rise to persistent by-products. This may lead in some instances to a switch to using non-oxidising biocides, although some of them are themselves persistent. The pressure to use chemicals which are less persistent, and for which ecotoxicological data are available in order to conduct risk assessment, may lead to a reduction of the variety used.

"Polluter pays" is implicit to much European legislation and is a recognition that there is a need to internalise environmental costs, making industry itself accountable for its emissions and liabilities, rather than the public purse. This accountability is seen to extend to the cost of regulation. In practice, the various mechanisms which enforce this principle exist at national rather than at European Union level.

The principle of subsidiarity means that it is for member states within the EU to implement Directives through national legislation and regulation, establishing standards of compliance no less strict than the Directive themselves stipulate. In practice, the diversity of pre-existing legislation and national regulatory policy tends to result in somewhat different arrangements locally.

The EU has thus introduced a variety of regulatory controls that have both a direct and indirect effect on the 
use of oxidising biocides in cooling waters. These controls are summarised below.

\subsection{EXISTING EU LEGISLATION}

\subsubsection{Market controls}

There is a considerable body of legislation (e.g. 76/769/EEC and amendments) relating to the marketing, use and disposal of dangerous substances, including organochlorine compounds. Whilst not directly impacting on the use of chlorine as a biocide, this contributes to a general pressure from a variety of sources to reduce the overall utilisation of chlorine. More recently, legislation has been proposed that may result in the imposition of controls on chlorine as a biocide: this may have a significant impact on current antifouling practices in the power generation sector (see 4.4).

\subsubsection{Discharge controls}

The use of chlorine based biocides results in the formation of organohalogens, as chlorination by-products, or the release of free oxidants that may combine with substances in the receiving waters to form halogenated organics. The EU has introduced a number of measures to prevent or limit the discharge of organochlorines to the aquatic environment, but to date the formation of organochlorine due to the use of chlorine as a biocide has not been considered as meriting control at Community level; the possibility remains.

One specific Directive is relevant.

\section{The Dangerous substances}

Directive (76/464/EEC)

This 'Framework' Directive (76/464/EEC) was adopted with the intention of reducing the input of a number of the most dangerous substances to the aquatic environment. The directive was based on two lists: pollution due to the discharge of List 1 substances was to be eliminated by the use of either uniform emission standards (UESs or end of pipe limits) or environmental quality standards (EQSs), whilst pollution by List II substances was to be reduced solely by the use of EQSs.

List I covers eight families of substances, considered dangerous by virtue of their toxicity, persistence and tendency to bioaccumulate, including 'organohalogen compounds and substances which may form such compounds in the aquatic environment'. The European Commission drew up a priority candidate list of substances to be considered for List I status. A significant number of the 132 substances on this list were chlorine based. To date daughter Directives have now been adopted for discharges of mercury, cadmium, hexachlorocyclohexane $(\mathrm{HCH})$, DDT, pentachlorophenol (PCP), carbon tetrachloride, the 'drins' group of pesticides (aldrin, endrin, dieldrin and 
isodrin), hexachlorobenzene (HCB), hexachlorobutadiene, chloroform, and most recently (in 1990), 1,2-dichloroethane, trichloroethylene, perchloroethylene and trichlorobenzene. In all cases, the Directives provide for emission limits and quality objectives, and they encourage the use of best available technology in new plant.

Only the trichlorophenols can be regarded as chlorination byproducts, and only chloroform, for which an EQS of $12 \mu \mathrm{g} / \mathrm{L}$ has been set for all waters, could be considered to have implications for the use of chlorine based biocides in cooling waters.

List II includes susbtances known to have a deleterious effect on the aquatic environment having a somewhat lesser significance than those of list I. This list includes metals such as zinc, nickel, chrome, lead, arsenic and copper, "biocides and their derivatives not appearing on list l", and substances such as cyanide and ammonia. The Directive required member states to provide environmental quality objectives and standards for list II substances.

This legislation is in the process of being replaced, and new lists of priority substances are being considered. This review will probably result in point source discharge controls from the most polluting industries, including the power generation sector, being covered by the Directive on Integrated Pollution Prevention and Control (IPPC), whilst the discharge of hazardous substances from other point sources as well as diffuse sources, agriculture etc., will be covered within the new "Ecology of Natural Waters Directive".

\subsubsection{Water Quality Controls}

The EU has adopted a number of measures stipulating concentrations, usually known as "environmental quality standards" (EQSs), that should not to be exceeded in designated use-related receiving waters. Because limits tend only to apply in nationally designated waters they have had fairly limited impact on cooling water discharges to date; this may change with the introduction of the developing Ecology of Natural Waters Directive (see 4.4).

Existing use-related Directives are summarised below.

\section{The Quality of Surface Water for Abstraction Directive(75/440/EEC)}

This Directive was adopted with the intention of setting minimum standards for surface waters intended for abstraction for drinking water purposes. Over 40 parameters are listed in an Annex, most of which are assigned environmental quality standards that should not be breached if an abstraction for drinking water purposes is to be made. One of the few listed parameters for which an EQS is not set is total extractable organic chlorine. It was expected at the time that standards for this parameter would be developed in the future, although this has not occurred. 
The Directive on Water Intended for Human Consumption (80/778/EEC)

This Directive (usually known as the Drinking Water Directive) was adopted with the intention of protecting human health by setting quality standards for drinking water to be met at the consumer's tap. Although, in effect, the Directive relates to the quality of a 'product', it has resulted in the introduction of measures to improve the quality of water abstracted from the aquatic environment in order to minimise treatment costs and ensure that certain onerous standards, for example that relating to the pesticide parameter, can be met.

Amongst the parameters listed in the Directive is one relating to residual chlorine. No standard is set for this parameter but member states are required to ensure that no substance used in the treatment of drinking water supplies should constitute a threat to human health. Because tainting of tap water may occur as a result of water treatment, the authorities may place additional pressures on dischargers who contribute to the presence of CBPs in the raw water prior to its abstraction for treatment and subsequent supply to the consumer. There are proposals to review this Directive (see 4.4).

\section{The Freshwater Fisheries Directive (78/659/EEC)}

This Directive was adopted with the intention of protecting freshwater fish by setting environmental quality standards (EQSs) for certain substances in designated freshwater fisheries. The Directive sets standards for 14 parameters, including one of $<5$ $\mu \mathrm{g} / \mathrm{L}$ for hypochlorous acid.

\section{The Shell Fisheries Directive (79/923/EEC)}

The Directive lays down the standards required to ensure a suitable environment for shellfish growth in specifically designated brackish and coastal waters. The Directive does not stipulate an EQS for chlorine but does require that no organohalogenated substance should be present that may be harmful to shellfish growth or use.

\section{The Biocidal Products Directive (98/8/EC)}

This Directive "On the placing of Biocidal Products on the Market" is intended to complement the existing Plant Protection Products ("Pesticides") Directive (91/414/EEC). It requires that biocides have prior authorisation before being marketed and used. All biocides presently purchased by the power industry will eventually require authorisation in this manner.

The Directive is provoking a system for authorising the use of biocides throughout the EU. Application for authorisation for a biocidal product will be the responsibility of the person placing the biocide on the market, and any submission will require: 
1. Prior recognition on a positive list of active ingredients

Only active ingredients listed in a subsequent Annex to the Directive will be permitted for use in authorised biocides. Inclusion of an active ingredient on the "positive list" will be dependent on it satisfying a number of human health and environment-related criteria. These are outlined in detail in Annex Il of the Directive and can be summarised as :

- description of the applicant,

- identity of the active substance,

- physical and chemical properties of the active substance,

- analytical methods of detection and identification,

- effectiveness against target organisms,

- toxicological profile for man and animals including metabolic effects,

- ecotoxicological profile including environmental fate and behaviour,

- measures necessary to protect man, animals and the environment,

- classification and labelling; and a summary and evaluation of the information gathered above.

\section{Submission of dossiers on the biocidal products}

In addition to the dossiers submitted to support the inclusion of active ingredients on the positive list, dossiers must also be submitted to support an application for authorisation to use each biocidal product. The data requirements are the same as those outlined above for active ingredients.
The competent authorities in each member state will only authorise a biocide if it satisfies the following criteria :

a) Its constituent active ingredients are on the positive list.

b) On the basis of the supporting dossier, the biocide:

- is sufficiently effective,

- has no unacceptable effect on the target organisms,

- has no harmful effects itself or as a result of its residues, on human or animal health, directly or indirectly (e.g. through drinking water, food or feed) or on ground water,

- has no unacceptable effects on the environment, having particular regard to the following considerations:

- its fate and distribution in the environment (particularly contamination of water including drinking water and ground water and its impact on non-target organisms),

- it does not cause unnecessary suffering and pain to vertebrates to be controlled.

c) The nature and quantity of its active ingredients and, where appropriate, any toxicological or ecotoxicological significant impurities and co-formulants, and its residues of toxicological or environmental significance, which may result from authorised uses, can be determined according to the information submitted in the appropriate dossiers.

d) Its physical and chemical properties have been determined and deemed acceptable for purposes of the appropriate use, storage and transport of the product. 
A biocide authorised in one member state shall be automatically authorised in any other member state within 120 days of a use application being made, unless the behaviour of the biocide or target organism differs markedly from one country to another. As a minimum, authorisations must be reviewed after 10 years, with a review being initiated immediately whenever new evidence arises that the existing authorisation may no longer be appropriate.

The Directive on Integrated Pollution Prevention and Control (IPPC) $(96 / 61 / E E C)$

This Directive was adopted in 1996, and forms the framework for the control of discharges from the most polluting industrial sectors in the EU, including most fossil-fuelled power plants. The intention is to more readily integrate the control of releases to different media: discharges to air and water, waste to landfill. The model for this initiative already exists in a number of member states, for example with Integrated Polution Control in the UK. IPPC however establishes a wider definition of "installations" and prescribes a wider list of processes. The primary control mechanism wil be the introduction and enforcement of Best Available Techniques (BAT).

EURELECTRIC, representing the electrivity generation sector across Europe, have produced a technical report on BAT for cooling water systems (EURELECTRIC, 1998).
The Directive on Drinking Water (98/83/EC)

The residual chlorine parameter of the original directive (80/778/EEC) has been removed but new standards for bromate $(10 \mu \mathrm{g} / \mathrm{L})$ and total THM's $(100 \mu \mathrm{g} / \mathrm{L})$ may have implications for disgharges of chlorinated cooling waters in the vicinity of drinking water abstraction points. An additional factor in such instances may be the requirements that taste and odour be acceptable to the consumer.

\subsection{FORTHCOMING EU LEGISLATION}

The natural development of earlier initiatives, together with a wide ranging review of European legislation, means that a number of potentially highly significant revised and completely new Directives will appear over the next few years. The outlines given here will inevitably become dated as the final versions of the text evolve.

\section{The Proposed Ecological of Natural Waters Directive}

This proposal was drafted following concerns that Member States were only seeking to protect surface waters with well defined uses, for example, abstraction for drinking water purposes and bathing, whilst little or no attempt was made to protect the general ecological quality of the aquatic environment as a whole. 
The Directive will require that a high or good level of ecological quality, be achieved in all waters, and not just those that have been designated for a particular use. When adopted, the proposed Directive will replace the Dangerous Substances, Surface Water Abstraction, and Freshwater Fisheries Directives.

This goal will be achieved by:

- defining operational targets for ecological quality in all EU surface waters,

- setting up a comprehensive monitoring system for water quality,

- preparing an inventory of all point source discharges and sources of diffuse pollution,

- drawing up a series of integrated programmes to improve surface water quality.

Annexes to the proposed Directive outline the elements upon which a definition of good ecological water quality should be based. These include:

- dissolved oxygen,

- concentrations of toxic and other harmful substances in water, sediment and biota,

- diseases in aquatic life forms,

- diversity of invertebrate, aquatic plant, fish, and higher vertebrate communities,

- sediment structure and quality,

- aesthetics of the site.

Although not yet finalised, implementation groups have already been formed by the member states.
Directive on the Control of Major Accident Hazards involving Dangerous Substances (COMAH) (96/82/EC)

In 1982 the EC adopted the 'Seveso' Directive on major accident hazards of certain industrial activities. The Directive required certain defined industrial installations at which dangerous substances were stored in greater than threshold quantities to introduce accident prevention programmes. It applied mainly to chemical, petrochemical and metal production facilities. The new $\mathrm{COMAH}$ Directive extends the provisions to cover many more industrial sites.

The basic requirements of $\mathrm{COMAH}$ now apply to any industrial site at which more than 10 tonnes of chlorine and/or 40 tonnes of bromine are stored. More stringent requirements relating to the identification of potential hazards and the preparation of a Major Accident Plan apply to sites at which more than 25 tonnes of chlorine and/or 100 tonnes of bromine are stored.

\subsection{OTHER INTERNATIONAL COMMITMENTS}

\subsubsection{Oslo and Paris Conventions, North Sea Ministerial Conferences (OSPAR, NSC)}

A number of international conventions bear upon members of the EU, either directly or indirectly. Amongst 
these, historically, were the "dumping at sea" and "discharge to sea" agreements embodied in the separate Oslo and Paris Conventions - subsequently revised and consolidated within the renewed Paris Convention. At the heart of this is an agreed need to protect the seas of the Northeast Atlantic from unsustainable industrial practice, from both diffuse and point sources. All the relevant member states have ratified this convention with the EU itself, are members of the allied commission. Both the workings of this commission and the associated North Sea Ministerial Conference process have a significant effect on environmental ragulatory policy within Europe, with signatories also being obliged to regard their detailed recommendations with a high level of commitment. As far as cooling water biocides are concerned, and as with current EU legislation, these initiatives have encouraged a reduction in the input of organochlorines to the aquatic environment.

The final declaration of the 1992 Ministerial meeting of the Oslo and Paris Commissions stated:

"as a matter of principle for the Convention area, discharges and emissions of substances which are toxic, persistent and liable to bioaccumulate, in particular organohalogen substances, and which could reach the marine environment should, regardless of their anthropogenic source, be reduced, by the year 2000 , to levels that are not harmful to man or nature with the aim of their elimination : to this end signatories of the
Convention are to implement substantial reductions in these discharges and emissions and where appropriate, to supplement reduction measures with programmes to phase out the use of such substances, and instruct the Commissions to keep under review what timetables this would require." More recently, in 1998, in what is now known as the "Sintra Declaration", all signatories agreed "to move toward the target of cessation of discharges... of hazardous... of hazardous substances by 2020 ". Whilst doing this they emphasized the importance of the Precautionary Principle. Procedures are now engaged for revising the list of priority hazardous substances.

\subsubsection{World Health Organization (WHO) Drinking Water Guidelines}

Although the WHO Drinking Water Guidelines (WHO 1993b) do not have any statutory (legal) basis, they have proved to be very influential in shaping EC legislation in this area. For example, the proposed revisions to the Drinking Water Directive have been based on the WHO Guidelines, (see section 4.4.).

A brief summary of the guidelines is provided (Table 4.1) with respect to the power industry's operations. It must be emphasised that these guidelines only apply to the presence of these substances in drinking water.

The use of chlorine as a disinfectant in drinking water supply is causing a number of worries for 
regulatory authorities due to the formation of halogenated by-products. At present, the established view is that the presence of low concentrations of these chemicals in drinking water is an acceptable trade-off ensuring the microbiological safety of water. However, this view is changing and there will be inevitable pressure placed on water supply companies to reduce their use of chlorine. Because of the broadly accepted need for a disinfection stage in drinking water treatment, pressure may be diverted to on other sources of disinfection by-products discharges e.g. from the use of chlorine and bromine as a biocide in cooling waters which discharge to waters also used for drinking water supply.
Table 4.1. - WHO Drinking Water Guidelines for Disinfectants and Disinfectant Byproducts.

\begin{tabular}{|c|c|c|}
\hline Compound & & $\begin{array}{c}\text { Guideline } \\
\text { value }\end{array}$ \\
\hline Free Chlorine & & $5 \mathrm{mg} / \mathrm{L}$ \\
\hline Chloramines & & $3 \mathrm{mg} / \mathrm{L}$ \\
\hline 2,4,6-Trichlorophenol & & $200 \mu \mathrm{g} / \mathrm{L}$ \\
\hline Bromoform & & $100 \mu \mathrm{g} / \mathrm{L}$ \\
\hline Dibromochloromethane & & $100 \mu \mathrm{g} / \mathrm{L}$ \\
\hline Bromodichloromethane & & $60 \mu g / L$ \\
\hline Chloroform & & $200 \mu \mathrm{g} / \mathrm{L}$ \\
\hline Trichloroacetic acid & & $100 \mu g / L$ \\
\hline Dichloroacetonitrile & & $90 \mu g / L$ \\
\hline Dibromoacetonitrile & & $100 \mu g / L$ \\
\hline Bromate & & $25 \mu \mathrm{g} / \mathrm{L}$ \\
\hline
\end{tabular}




\section{5.}

\section{CONCLUSIONS AND RECOMMENDATIONS}

The design and optimization of antifouling methods involves technological, biological, toxicological and ecotoxicological considerations. Selection of the best method is always based on three criteria :

- technical feasibility,

- cost,

- environmental acceptability.

Across Europe, there is a need to maintain and build an understanding of :

a. The presence of new "invasive" species which may present a fouling risk;

b. Likely settlement periods and growth rates of fouling species, and the means of monitoring;

c. Worked examples optimising controls applied to fouling.

There is an express need to build up the appropriate databases in common ownership.

\subsection{WATER FILTRATION SYSTEMS AND CLEANING UP ARE THE MOST COMMON ANTI-FOULING PROCESSES}

a. These are practices common to all power stations and industrial cooling water circuits; to greated or lesser degree, such systems reduce the need for chemical treatment.

b. Water filtration is necessary to remove drifting organisms entrained at the water intake and, further downstream, to protect heat exchangers from detachment of fouling organisms. There are several types of filtration systems now in use, including rough grids equipped with trash racks, rotating filters and microfiltration, well suited for various drifting and settling organisms.

c. Cleaning procedures include continuous on-line mechanical cleaning of condenser tubes with sponge balls, as well as cleaning during scheduled shutdowns, maintenance periods or in the event of incidents. $A$ 
number of cleaning processes are possible:

- manual removal of organisms settled on the concrete walls of basins, pipes, culverts, etc. This is done underwater by divers, or after draining the area to be cleaned,

- cleaning of biofilm and mineral deposits on heat exchangers with high pressure jets,

- suction and pumping of mud and deposits.

d. Filtration and cleaning can be costly, especially since sophisticated systems and regular maintenance are required.

\subsection{DESIGN OF CIRCUITS.}

It is generally advised that:

a. For water intake pipes, avoid square sections and bends.

b. If possible, maintain the water velocity above the critical thresholds for the target organisms :

$->1 \mathrm{~m} / \mathrm{s}$ to eliminate bryozoa and Zebra mussels

$->2 \mathrm{~m} / \mathrm{s}$ to minimize, and around $3 \mathrm{~m} / \mathrm{s}$ to completely eliminate marine biofouling.

c. Keep all concrete walls in good condition; settlement of biofouling organisms is facilitated by irregularities on surfaces.

\subsection{PHYSICAL TREATMENT}

Some alternatives to chemical dosing are possible:

a. Heat treatment, applied by recirculation, is an effective method for the control of macrofouling in fresh water, estuarine and sea water, but it requires specific design of circuits. It is very difficult to back-fit, in particular in complex cooling systems such as large nuclear power stations with cooling towers. Heat treatment by direct water heating is technically possible in some cases (temporarily closed galleries with special filling systems), but is costly.

b. Heat controls neither bacterial slime nor certain thermophilic pathogens.

c. Heat treatment requires a permit for the discharge of water above normal regulatory thermal limits.

d. New non-toxic coatings can, to a large extent, reduce macrofouling settlement and facilitate the clean-up of fouled walls. They do, however, pose certain problems:

- They generally require specific conditions for application (dry, clean surfaces) and top coatings have to be applied every 4 to 5 years;

- they are costly;

- they are not suitable for protecting heat exchangers, wherever there is a need to maintain high thermal efficiency. 


\subsection{CHEMICAL TREATMENT.}

The principal means of managing the residual risk of biological fouling on operational power stations is chemical treatment, but there is increasing regulatory pressure on such practices :

a. Chemical treatments can be tightly optimized only if one has access to precise biological data (monitoring of biofouling, reproduction and larval settling periods, growth rates of juveniles), but they cannot be completely eliminated in many cases:

- in areas where macrofouling growth is very rapid,

- in protecting plate heat exchangers,

- in disinfecing circuits containing thermophilic pathogens.

b. Chlorine is currently the basis of the most commonly-used treatments, as :

- Chlorine can be generated on site at marine power stations by electrochlorination at an acceptable cost;

- There is long-term data available on industrial experience with lowlevel chlorination $(0.5-1.0 \mathrm{mg} / \mathrm{L})$ in the UK, France Italy, and the Netherlands;

- Chlorine is efficient against all fouling categories from bacteria to molluscs;

- The acute toxicity generated by oxidizing compounds disappears rapidly.

The environmental risk of chlorine by-products (CBPS) such as THMs, haloacetic acids, AOX, remains a concern in the production of drinking water. One means of addressing this is through the use of monochloramine, which reduces the formation of THM and $A O X$ in fresh water.

Low level chlorination of sea water produces low amounts of CBPs which have no acute or effective chronic toxicity on the marine littoral ecosystem.

c. Other oxidizing agents :

Ozone and chlorine dioxide are thought to have less environmental impact due to the reduction of CBPs, mainly THMs.

Ozone is efficient against macrofouling and bacterial slime in fresh water. Some experiments using ozone on closed circuits are promising but ozonation is costly compared with chlorine. In sea water, ozonation generates free bromine and related CBPs; it is therefore not a suitable substitute for chlorine.

Chlorine dioxide in low doses 10.2 $\mathrm{mg} / \mathrm{L}$ ) has been used in Italy and Spain in power stations using sea water. The consumption of chlorine dioxide by sea water is generally very low, but in fresh water the demand can reach $2 \mathrm{mg} / \mathrm{L}$ due to the presence of nitrite ions and other reducing agents.

Chlorine dioxide is more costly than chlorine but it is easily applied with specially designed on-site production systems. There are, however, significant safety measures required (risk of explosion).

Peroxides such as hydrogen peroxide or peracetic acid produce no 
known by-products, but have not yet seen application in large cooling water systems.

\section{d. Organic compounds:}

To be used in large cooling systems, an organic compound must not be persistent or toxic, nor be bioaccumulated after release into the aquatic environment. The worst historical example is TBTO.

Several organic antifouling compounds are efficient against molluscs and can control the major macrofouling organisms in river waters.

Some compounds containing neither aromatics nor quaternary amines, and which are degradable by common bacteria such as fatty amine polymers, may yet provide good alternatives to oxidizing agents, but they remain relatively unknown as far as either their effectiveness and environmental acceptability are concerned.

\subsection{THE FUTURE OF ANTIFOULING METHODS}

The great bulk of power generation plant in europe operates efficiently only by using the basic tools of physical screening, physical cleaning, and chemical dosing. These tools are well known by the industry, but the regulatory environment is changing and any casual use of chemical dosing, which might cause environmental harm, is challenged. There are a number of avenues where further invetigation may well be profitable:

a. First of all, improvements must be made in existing methods.

(i) Water filtration covers a wide range of systems, from rough filtration using grid-trash racks to fine mesh screens and microfiltration. Better solutions for washing the fine mesh screens and microfilters need to be found in the near future. New systems for the removal of large amounts of algae and gelatinous organisms at water intakes are also needed.

(ii) Cleaning processes can be improved by standardizing procedures. Underwater cleaning techniques are needed which can be applied to large cooling water systems.

(iii) Design options for applying heat treatments to specific parts of cooling systems should be considered.

(iv) Chlorine treatment can be optimized by on-site biological monitoring; high-frequency intermittent injection (pulse chlorination) is one possible solution.

(v) The interaction of chemical fouling (scaling) and biological fouling in cooling towers continues to need to be taken into account.

b. New methods such as UV, electrical fields, natural toxins or pathogens, remain far from industrial application, but it will necessary to monitor developments in this field worldwide; the possibility of a "pleasant surprise" cannot be excluded. 


\section{References}

Abarnou A., 1979. Trihalométhanes formés par chloration de l'eau de mer. $2^{\mathrm{e}}$ Journées de la Thermoécologie. Institut Scientifique et Technique des Pêches Maritimes. 14-15 Novembre 1979.

Ackerman J.D., Cottrell C.M., Ethier C.R., Allen D.G. \& Spelt J.K., 1995. A wall jet to measure the attachment strength of zebra mussels. Can J. Fish. Aquat. Sci. 52, pp. 126-135.

Alabaster J.S. \& Lloyd R., 1980. Water quality criteria for freshwater fish. Butterworth \& Co. London. ISBN 0-40810673-5, 297 pp.

Aldridge D.W. \& McMahon R.F., 1978. Growth, fecundity and bioenergetics in a natural population of the Asiatic Freshwater Clam, Corbicula manilensis Philippi, from north central Texas. J Molluscan Studies 44, pp. 49-70.

Alexander H.C., Bodner K.M. \& Mayes M.A., 1983. Evaluation of the OECD "fish prolonged toxicity study at least 14 days". Chemosphere 12, pp. 415423.

Allen F.E., 1953. Distribution of marine invertebrates by ships. Aust. J. Mar. Fresh. Res. 7, pp. 307-316.

Allonier A.S., 1996. Evaluation of the performance of an organohalogenated compound measurement device using microcoulometry and comparison with gas chromatography. Hydroecol. Appl. 8 (1,2), pp. 193-210.

Allonier A.S., Khalanski M. \& Arehmouch L., 1997. Colorimetric measurement of
Mexel 432. Application to the study of evolution of the product in river waters. EDF.DER Report HE/31/97/010.

Allonier A.S. \& Khalanski M., 1997. Chlorination by-products in sea water. EDF DER Report HE-31/97/027, 12 p.

Alzieu C., Héral M., Thibaud M.J. \& Boutier B., 1980. Evaluation des risques dus à l'emploi de peintures antisalissures dans les zones conchylicoles. Rev. Trav. Inst. Pêches Marit., 44, pp. 301-348.

Ambrogi R., Festa V. \& Toscano A., 1994. Acute toxicity of chlorine dioxide on juvenile Dicentrarchus labrax. Relaz. ENEL-DSR-CRAM E4/94/11 presented at VI Congress of S.I.T.H. Venezia 2629 September 1994.

Ambrogi R., 1992. Fouling control systems for water treatment. Paper presented at the 8th International congress on marine corrosion and fouling. Sept. 21-25, Taranto (Italy).

Ambrogi R., 1993. Fouling control system for water treatment. Oebalia, 19, suppl., pp. 355-373.

Ambrogi R., 1997. Environmental impact of biocidal antifouling alternative treatments on seawater once-through cooling systems. In Chlorine dioxide and disinfection. Proceedings of "First European Symposium on Chlorine Dioxide and Disinfection". Rome 1996, November 7-8. Collana Ambiente, vol. 17, pp. 119-132. 
Anderson D.B. \& Richards B.R., 1966. Chlorination of sea water. Effects on fouling and corrosion. Journal of Engineering and Power, Trans ASME. July, pp. 203-208.

Anderson D.R. \& Lusty E.B., 1980. NUREG/CR-089 Richland, Wa; Pacific NW Labs, pp. 8-26. Ref. from Howard P.H. (ed), (1990) Handbook of environmental fate and exposure data for organic chemicals. Lewis Publishers Inc., Chelsea, USA.

APHA-AWWA-WPCF, 1976. Standard methods for the examination of water and wastewater. 14th edition Washington.

APHA-AWWA-WPCF., 1992. Standard methods for the examination of water and wastewater. 17th edition Washington.

Aprosi G., Bidard F. \& Nepveu de Villemarceau C., 1986. Expérience d'exploitation des aéroréfrigérants des centrales nucléaires françaises: Hydrobiologie-chimie aquatique. Revue Générale Nucléaire $n^{\circ} 5$, Septembre/Octobre 1986, pp. 425-429.

Aprosi G. \& Chauvel D., 1990. The quantity of algae settling on the inside shell of cooling towers and the consequence on the wear of the shell. $7^{\mathrm{e}}$ Congrès AIRH. Léningrad 1990. Rapport EDF/DER HE/31-90.05, 9 pp.

Aprosi G. \& Costaz J.L., 1989. La formation des algues sur les coques des réfrigérants. Rapport EFD/DER $\mathrm{HE} / 31-89.14,10 \mathrm{pp}$.

Aprosi G. \& Mossé J., 1989. Algues de coque d'aerorefrigerants. Composition et premiers elements quantitifs. Rapport EDF/DER HE/31-90.05, 9 pp.

Aprosi G. \& Nepveu de Villemarceau C., 1988. French operational experience on fouling problems (Algae: Bryozoa) in cooling towers. Paper presented to the 6th IAHR Cooling Tower Workshop, Pisa (Italy) Oct. 4-7, 1988, 24 p.

Arehmouch L., Tfibel V., Chaillou C., Ghuillebaert F. \& Roubaud P., 1998.

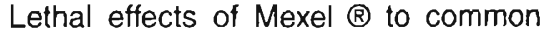
carp embyrological stages in river water: influence of physicochemical parameters in synthetic iso water. Environ. Toxicol. Chem., vol. 17, n 9, pp. 17671776.

Arndt E.A., 1965. Über das Vorkommen und die Morphologie von Cordylophora caspia (Pallas), (Hydrozoa), in der Umgebung der zoologischen Station Tvärminne, Finland. Commentat Biol 28, pp. 1-8.

Arndt E.A., 1973. Ecophysiological and adaptational problems confronting animals living in brackish water. Oikos 15, pp. 239-245.

Arndt E.A., 1984. The ecological niche of Cordylophora caspia (Pallas, 1771). Limnologica (Berlin) 15, pp. 469-477.

Bachmann V., Cegielka E., Wagner P., Usseglio-Polatera P. \& Moreteau J.-C., 1995. Installation de l'Amphipode Corophium curvispinum et de la palourde asiatique Corbicula $\mathrm{sp}$ dans le cours francais de la Moselle. Hydroécologie Appliquée, pp. 185-190.

Baldwin B.S., 1995. Settlement and metamorphosis of larvae Zebra and Quagga mussels : implications for their colonization and spread. In Fifth International Zebra mussel and Aquatic Nuisance Organisms Conference, Toronto, Ontario.

Bamber R.N., 1990a. Environmental impact assessment, the example of marine biology and the UK power industry. Mar Pollut Bull 21, pp. 270-274.

Bamber R.N., 1990b. Power station thermal effluents and marine crustaceans. $J$ Therm Biol 15, pp. 91-97.

Bamber R.N., 1994. A literature review of the response of migrating salmonids to raised water temperature, with particular reference to heated effluents. Fawley arl Ltd Report to KEMA, FCR 115/94, pp. 21 p.

Bamber R.N., Seaby R.M.H., Fleming J.M. \& Taylor C.J.L., 1994. The effects of entrainment passage on embryonic deve- 
lopment of the Pacific oyster Crassostrea gigas. Nuclear Energy 33, pp. 353357.

Bamber R.N. \& Spencer J.F., 1984. The benthos of a coastal power station thermal discharge canal. J. mar. biol. Ass. UK 64, pp. 603-623.

Bard D. \& Siclet F., 1995. Amibes libres et santé publique. Editions ENSP, Electricité de France. ISBN 285952 751, $142 \mathrm{p}$.

Barnes H., 1971. A review of some factors affecting settlement and adhesion in the cyprids of some common barnacles. In : Manly R.S. (ed.) Adhesion in biological systems. Academic Press, New York, pp. 89-111.

Barnes R.S.K., 1994. The brackish water fauna of Northwestern Europe. Cambridge University Press.

Barrow M.E. et al., 1980. Dynamic exposure hazard assessement. Toxic. Chem. Ann Arbor, MI: Ann Arbor Press, pp. 379-392.

Barton L.K., 1990. Control of Zebra mussels at CEI facilities. Annual Meeting of the American Power Conference. April 2325 1990, Chicago (USA), 5 pp.

Bayne B.L. (ed.) 1976 Marine mussels: their ecology and physiology. Cambridge University Press.

Behning A., 1914. Corophium curvispinum Sars und seine geographische Verbreitung. Zool Jahrb Zeitschr. Syst. Geogr. Biol. 37, pp. 385-400.

Belanger S.E. \& Farris J.L., 1985. Sediment preference of the freshwater Asiatic clam Corbicula fluminea. Nautilus 99, pp. 66-73.

Belluati M., Bartole L. \& Bressan G., 1997. In Chlorine dioxide and disinfection. Proceedings of "First European Symposium on Chlorine Dioxide and Disinfection". Rome 1996, November 7-8. Collana Ambiente, vol. 17.

Ben Amor H., De Laat J., Dore M., 1988. Incidence de la préoxidation par $\mathrm{ClO}_{2}$ sur le potentiel de formation des com- poses organohalogènes. Environ. Technol. Letters 9, pp. 1105-1114.

Benarde A., Israel B.M., Oliveri V.P. Grandstrom M.L., 1965. Efficiency of $\mathrm{ClO}_{2}$ as a bactericide. Appl Microbiol 13, pp. 776-780.

Benefield L.D., Judkins J.F. \& Weand B.L., 1982. Process chemistry for water and wastewater treatment Prentice-Hall Inc. Englewood Cliffs NJ, 510 pp.

Berger H-D., Langner K., Watermann B., 1994. Natürliche Biozide un biozidfrei Mittel zur Bewuchshemmung, ihre Effectivität und Anwendung auf Schiffen im marine Bereich, Teilvorhabe 1 zum Forschungsvorhaben 'Möglichkeiten zur biozidfreien Konservierung technische Produkte und Verfahren'. Im Auftrag des Umweltbundesambtes. ISSN 0722-186X.

Betz Laboratories Inc., 1991. Betz handbook of industrial water conditioning.

Blank L.W., 1984. Control of algal biofouling at High Marnham; 1981-83. CERL Note No TPRD/L/2649/N84.

Blum D.J.W. \& Speece R.E., 1991. A database of chemical toxicity to environmental bacteria and its use in interspecies comparisons and correlations. Res J Water Pollut C 63, pp. 198207.

Blume W.J., Fraleigh P.C. \& Van Cott W.R., 1994. Evaluation of copper ions and aluminium floc for preventing settlement of Zebra mussels. Fourth International Zebra Mussel Conference. Madison, Wisconsin. EPRI TR-104029, Proceedings, pp. 15-31.

Boetling R.S. \& Alexander M., 1979. Appl. Environ. Microbiol. 37, pp. 1211-1216.

Bolsee F., Delanaye J.-N., Deleval J., Duvivier L., Roothooft R. \& Van Damme A., 1995. Influence des types de packings utilisés dans les réfrigérants atmosphériques sur la précipitation du carbonate de calcium. Tribune de l'Eau, 5/95, Sept-Oct., pp. 43-49.

Bordet F., 1983. Conception des ouvrages d'eau des centrales nucléaires littora- 
les. Note EDF E-SE.E.3011 20/09/83, $20 \mathrm{p}$.

Bruntland G.H., 1987. Our common future. Report of the World Commission on Environment and Development. Oxford University Press.

Bryden A.D. 1997. Pulsed acoustics and water supply, system benefits and assessment for the prevention of zebra mussel veliger settlement. Communication at Seventh International Zebra Mussel and Aquatic Nuisance Species Conference. New Orleans.

Bucaille D., 1981. Etude expérimentale des effets de la chloration sur la biologie de la moule (Mytilus edulis L.) Mollusque Lamellibranche. Thèse $3^{\theta}$ Cycle. 26 mai 1981. Université de Caen. 129 pp.

Burch J.Q., 1944. Checklist of West American mollusks, Family Corbiculidae. Minutes of the Conchological Club of Southern California 36, pp. 18.

Cabanes P-A., Pringuez E., Siclet F., Khalanski M. \& Pernin P., 1997. Continuous chlorination to control pathogenic amoebae in a closed-loop power plant. The Environmental Professional, Vol. 19, pp. 192-200.

Callow M.E., 1993. A review of fouling in freshwaters. Biofouling 7, pp. 313-327.

Cavanagh J.E et al., 1992. Ozonation Byproducts, Identification of Bromohydrins from the Ozonation of Natural Waters with Enhanced Bromide Levels. Environ. Sci. Technol. 26, pp. 16581662.

CEC, 1976. Noxious effects of dangerous substances in the aquatic environment. Commission of the European Communities, ENV/588/76.

CEC, 1982. Study of noxious effects of dangerous substances in list II. Final report of the Commission of European Communities, Brussels EUR 7970/11.

CEMAGREF Suivi hydrobiologique du Rhône au Bugey. In EDF.CNPE du Bugey. Rapports annuels d'environne- ment, années 1989, 1990, 1991, 1992. 1993, 1994.

Chamberlain A.H., 1988. In : CAS Sequeira and KA Tiller (eds) Microbial corrosion, Elsevier Applied Science.

Chandrasekaram S. \& Dexter C., 1993. Factor Contributing to Ennoblement of Passive Metals Due to Biofilm in Seawater, Corrosion Control for Low-Cost Reliability. Proceedings of "12th International Corrosion Congress", NACE, pp. 3696-3707.

Characklis W.G., 1981. Fouling biofilm development. A process analysis. Biotechnol. Bioeng. 23, pp. 1923-1960.

Characklis W.G. \& Cooksey K.E., 1983. Biofilms and microbial fouling. Adv. Appl. Microbiol. 29, pp. 93-138.

Characklis W.G., 1990. Kinetics of microbial formation in biofilm, W.G. Characklis \& K.C. Marshall (eds), p. 233.

Clare A.S., Freet R.K. \& McClary M., 1994. On the antennular secretion of the cyprid of Balanus amphitrite, and its role as a settlement pheromone. J. Mar. Biol. Ass. UK 74, pp. 243-250.

Claudi R. and Evans D.W., 1993. Chemical addition strategies for zebra mussel (Dreissemia polymorpha) control in once through Service water system, in Zebra Mussels Biology, Impacts and Control, Nalepa Y.F. and Schloesser D.W. (eds) Lewis Publishers, pp. 563573.

Claudi R. \& Mackie G.L., 1994. Practical manual for zebra mussel monitoring and control. Lewis Publishers, London, $227 \mathrm{p}$.

CNEXO, 1983. Etude écologique de projet. Site de Penly, deuxième cycle, rapport general.

Combaz P., 1994. Entartrage des réfrigérants atmosphériques. Rapport EDFDE-SEPTEN PX/97 046, $14 \mathrm{p}$.

Command D.A. \& Matthews R.C., 1994. The first-oxidizing molluscicide treatment in Canada. Fourth International Zebra Mussel Conference. Madison, 
Wisconsin. EPRI TR-104029, Proceedings, pp. 33-44.

Couri D., Abdel-Rahman M.S. \& Bull R.J., 1982. Toxicological effects of chlorine dioxide, chlorite and chlorate. Environ. Health Perspect. 46, pp. 13-17.

Cox G.C. \& Humphris T.H., 1976. The use and reuse of sewage effluent. J. Inst. Wat. Pollut. Cont. No 4.

Cristiani, G. Bianchi, 1997 "Microbial Corrosion Prevention in ENEL Power Plants", Microbial induced Corrosion, $n$. 22, European Federation of Corrosion Publications, The Institute of Materials ISSN 1354-5116, London, 1997.

Cristiani, A. Mollica \& Ventura G., 1997. "On-line monitoring of biofilm and T.R.O. by a new ENEL'S system", "Understanding Heat Exchanger Fouling and Its Mitigation" conference, 11-16 maggio, Lucca, 1997.

Dall P.C. \& Hamburger K. 1996. Recuitment and growth of Dreissena polymorpha in Lake Esrom, Denmark. Limnologica 26 (1), pp. 27-37.

Darby J.L. \& Snider K.E., Tchobanoglous G., 1993. Ultraviolet disinfection for wastewater reclamation and reuse subject to restrictive standards. Water Environmental Research, vol 65; 2, pp. 169-180.

Dare P.J., 1973. The stocks of young mussels in Morecambe Bay Lancashire shellfish. Info Leaflet No 28 MAFF UK, $14 \mathrm{p}$.

Davenport J., Oxford P. \& Awobamise A., 1986. A study on the effectiveness of antifouling electrodes in the marine environment. Water Research, vol. 20, $\mathrm{n}^{\circ} 6$, pp. 703-708.

Davis M.H. \& Coughlan J., 1983. A model for predicting chlorine concentration within marine cooling water circuits and its dissipation at outfalls. In Water chlorination, pp. Environmental impact and health effects, Jolley et al. (eds) Vol. 4, Ann Arbor Sci. Publs. 1983, pp. 347357.
De Wever H. \& Verachter H., 1997. Biodegradation and toxicity of benzothiazoles. Wat. Res. vol. $31,11, \mathrm{pp}$. 2673-2684.

De Wolf P., 1973. Ecological observations on the mechanisms of dispersal of barnacle larvae during planktonic life and settling. Neth. J. Sea. Res. 6, pp. 1-129.

Dedieu L., Hort C., Martinez-Dominguez A., Rola M. \& Roques H., 1994. Contribution à l'étude des phénomènes d'entartrage. Première partie. Tribune de l'Eau, 571 (5. , Sept-Oct., pp. 3-19.

Dejoux C., 1988. La pollution des eaux continentales africaines. Éditions de I'ORSTOM. Collection Travaux et Documents $n^{\circ} 213$. Chapitre B II. Le contrôle des mollusques vecteurs de schistosomiases, pp. 110-137.

Delattre J.-M. \& Oger C., 1981. Naegleria pathogènes et pollution thermique. J. Fr. Hydrol. 12 (35. , asc. 2), pp. 239244.

D'ltri F. (ed.), 1997. Zebra mussels and Aquatic Nuisance Species. Ann Arbor Press inc. Chelsea, Mi 48118.

Dixon D.R., 1981. Reproductive biology of the serpulid Ficopomatus enigmaticus in the Thames estuary, SE England. J. Mar. Biol. Assoc. UK 61, pp. 805-815.

Dobbs M.G., Cherry D.S., Scott J.C. \& Petrille J.C., 1995. Environmental asessment of an alkyl dimethyl benzyl ammonium chloride based molluscicide using laboratory tests. Fifth International Zebra Mussel and Aquatic Nuisance Organisms Conference. Toronto, Feb. 21-24.

Dobson J.G., 1946. The control of fouling organisms in fresh and saltwater circuits Trans ASME, pp. 247-265.

Dohorty F.G., Farris J.L., Cherry D.S. \& Cairns Jr J., 1986. Control of freshwater fouling bivalve Corbicula fluminea by halogenation. Arch. Environ. Contam. Toxicol. 15, pp. 535-542.

Doré M., 1989. Chimie des oxydants et traitement des eaux. Lavoisier, Paris. 
Dow Chemicals, 1980. Bromine chloride newsletter, 101-165, September 1980.

Dreves L., Erard Le Denn E., Lunven M., Martin J., Miossec D., Piriou J.-Y. \& Quintin J.-Y., 1994. Surveillance écologique et halieutique du site de Flamanville. Année 1993. Rapport IFREMER DEL/BREST- - 94.09 pour EDF, 105 pp.

Dubois Ch., 1995. Biologie et démo-écologie d'une espèce invasive, Corbicula fluminea (Mollusca, Bivalvia) originaire d'Asie. Etude en milieu naturel (canal latéral à la Garonne) et en canal expérimental. Thèse de doctorat de l'Université Paul-Sabatier (Toulouse). 12 Novembre 1995, 147 p.

Duvivier L., 1993. Formation et élimination des organo-halogénés lors de la désinfection des eaux. Thèse de doctorat es-sciences. Université catholique de Louvain-la-Neuve (Belgique).

Duvivier L. \& Vanmaele R., 1995. Centrale de Chooz B Biologie. Rapport de synthèse. Rapport LABORELEC C03-80095-005/F/LDU/RVM, $18 \mathrm{p}$.

Duvivier L., Leynen M., Ollivier F. \& Van Damme A., 1996. Fighting zebra mussel fouling with ozone. In Proceedings of the EPRI PSE Service water Systems Reliability Improvement Seminar. June 25-27, Daytona Beach, Florida, $14 \mathrm{p}$.

EEC, 1975. Council directive concerning the quality required of surface water intended for the abstraction of drinking water in the Member States (75/83/EC). Official Journal L 194, 25/07/75.

EEC, 1975. Council directive of 25 May 1975 on the quality of surface water for the abstraction of drinking water (75/460/EEC) Official Journal 194.

EEC, 1976. Council directive of 6 May 1976 on pollution caused by certain dangerous substances discharged into the aquatic environment (black and grey lists) (76/464/EEC) Official Journal L129, 18/5/76.
EEC, 1976. Council directive of 8 December 1975 concerning the quality of bathing water (76/160/EEC) Official Journal L31, 5/2/76.

EEC, 1978. Council directive of 18 July 1978 on the quality of waters needing protection or improvement in order to support fish life (78/659/EEC) Official Journal L22, 30/11/78.

EEC, 1979. Council directive of 30 October 1979 on the quality required of shellfish (79/923/EEC) Official Journal L281, 10/11/79.

EEC, 1980. Council directive of 15 July 1980 relating to the quality of water intended for human consumption (80/778/EEC) Official Journal L229, 30/8/1980.

EEC, 1980. Council directive of $17 \mathrm{De}$ cember 1979 on the protection of groundwater against pollution caused by certain dangerous substances (80/68/EEC) Official Journal L20, 26/1/80.

EC, 1996. Council directive concerning integrated pollution prevention and control (IPPC Directive - 96/61/EC). Official Journal L 257, 10/10/96.

EC, 1998. Council directive on the quality of water intended for human consumption (98/83/EC). Official Journal L 330, 05/12/98.

EC, 1998. Directive of the European Parliament and the Council concerning the placing of biocidal products on the market, the establishment at Community level of a list of active substances which may be used in biocidal products (98/8/EC). Official Journal L 123, 24/4/1998.

Efremov A.D., 1975. Treating the effluent after chemical cleaning in a recirculating cooling system. Teploenergetika Akad. Nauk. SSSR. Energ. Inst. 22, pp. 79-80.

ENEL-CRAM, 1996. Manuale per il controllo dei periodi di insediamento del macrofouling e per l'ottimizzazione dei 
trattamenti di clorazione. Report $\mathrm{n}^{\circ}$ 19960016, April 1996, 28 p.

EPRI, 1983. Symposium on Condenser Macrofouling Control Technologies, pp. The State of the Art. Dias-Tous IA Miller MJ and Mussali YG (eds) Hyannis Mass. USA.

EPRI, 1988. 6th IAHR Cooling Tower Workshop. Pisa, Italy. 4-6th Oct. 1988.

EPRI, 1989. Non-toxic foul-release coatings. EPRI GS-6566. Final report, October 1989.

EPRI, 1992. Zebra mussel monitoring and control guide EPRI-TR-101782 December 1992.

EPRI, 1993. Condensor microfouling control handbook. Final Report, October 1993 TR-102507.

Erickson S.J. \& Freeman AE., 1978. Toxicity screening of fifteen chlorinated and brominated compounds, using four species of marine phytoplankton. In, Water Chlorination, Environmental impact and health effects, R.L. Jolley et al. (eds), Ann Arbor Sci, Vol. 2, pp. 307311.

EURELECTRIC, 1998. BAT for cooling systems. $78 \mathrm{p}$.

Ewans D.W., Griffiths J.S. \& Koopmans R., 1992. Options for controlling zebra mussels. Ontario Hydro research review, $n^{0} 7$, pp. 1-25.

Fauvel P., 1923. Un nouveau serpulien d'eau saumâtre Mercierella n.g. enigmatica n. sp. Bull. Soc. Zool. Fr. 46, pp. 424-430.

Fears C.D. \& Mackie G.L., 1997. Effectiveness of low-level electric current (AC) for preventing settlement of zebra-quagga mussels on concrete and steel panels after one year of exposure at Nanticoke T.G.S. forebay. Poster presented at Seventh International Zebra Mussel and Aquatic Nuisance Species Conference. New Orleans.

Fejgina Z.S., 1959. Utilisation d'eau chaude pour lutter contre la prolifération des Dreissena dans les centrales thermiques (in Russian). Elektichesskie Stantsii 10, pp. 38-40.

Fisher S.W., Stromberg P.S., Bruner K.A. \&. Boulet L.D., 1991. Molluscicidal activity of potassium to the zebra mussel, Dreissena polymorpha: toxicity and mode of action. Aquatic Toxicology, 20 , pp. 219-234.

Foster B.A., 1969. Tolerance of high temperatures by some intertidal barnacles. Mar. Biol. 4, pp. 326-332.

Fraser, 1986. Peroxygens in environmental protection. Effluent and Water Treatment Journal, pp. 186-199.

Freitag D. et al., 1982. Ecotox. Environ. Safety, 6, pp. 60-81. Ref. from Howard P.H. (ed.), (1990) Handbook of environmental fate and exposure data for organic chemicals. Lewis Publishers Inc., Chelsea, USA.

Furman E.R., Yule A.B., 1991. Balanus improvisus Darwin in British Estuaries, gene flow and recolonization, pp. 273276. In : Elliott M. and J.P. Ducrotoy (eds) Estuaries and Coasts: spatial and temporal intercomparisons. ESCA 19 Symp. University of Caen, France. Olsen and Olsen Internat. Symposium Series.

Garey J. \& Gross C., 1997. Long Island Lighting Company Mexel Trials, $3 \mathrm{p}$.

Garric J. \& Migeon B., 1983. Étude du cycle de reproduction de Dreissena polymorpha sur le Rhône en aval de Lyon. Rapport EDF-DER. HE/31-83.22. $42 p$.

Geiger D.L., Northcott C.E., Call D.J. \& Brooke L.T. (eds), 1984/85. Acute toxicities of organic chemicals to fathead minnows Vols I and II. Centre for Lake Superior Environmental Studies Univ. Wisconsin-Superior Superior Wisconsin, pp. 326.

Geraci S., Ambrogi R., Festa V. \& Piraino S., 1993. Field and laboratory efficacy of chlorine dioxide as antifouling in cooling systems of power plants. Oebalia 19, pp. 383-393. 
GESAMP, 1984. Thermal discharges in the marine environment. IMO/FAO/ UNESCONMONHO/IAEA/UNEP Joint Group of Experts on the Scientific Aspects of Marine Pollution. Reports and Studies No. 24.

Geyer at al., 1982. Chemosphere, 11, pp. 1121-1134. Howard P.H. (ed.), (1990) Handbook of environmental fate and exposure data for organic chemicals. Lewis Publishers Inc., Chelsea, USA.

Giamberini L., Czembor N. \& Pihan J.-C., 1994. Effects of Mexel 432 on the settling, detachment and mortality of adult zebra mussels. Fourth International Zebra Mussel Conference. Madison, Wisconsin. EPRI TR-104029, Proceedings., pp. 73-81.

Gibson C.I., Tone F.C., Schirmer R.E. \& Blaylock J.W., 1980. Bioaccumulation and depuration of bromoform in five marine species. Water Chlorination Environmental Impact and Health Effects, Jolley et al. (eds) Ann Arbor Sci. Vol. 3, pp. 517-533.

Gillet A. \& Micha J.-C., 1985. Étude de la biologie d'un mollusque bivalve en vue de son élimination dans le circuit de la centrale nucléaire de Tihange. La Tribune du CEBEDEAU $n^{0} 504,38, p p$. 3-28.

Gilpin R.W., Dillon S.B., Keyser P., Androkites A., Berube M., Carpendale N., Skorina J., Hurley J., 1985. Disinfection of circulating water systems by ultraviolet light and halogenation. Wat. Res. 19, pp. 839-848.

Gitay A. \& Glazer A., 1979. Biological fouling in Israel power station and in a proposed inter sea conduit. Isr. J. Zool. 28 (1), p. 61.

Glazer A. \& Gitay A., 1988/89. The fouling communities at the Haifa and Adera power station (Mediterranean coast of Israel). Isr. J. Zool.. 35 (1/2), p. 88.

Gledhill T., Sutcliffe D.W. \& Williams W.D. 1976. A revised key to the British species of Crustacea, Malacostraca occurring in fresh water. Freshw. Biol. Assoc. Sci. Publ. 32, pp. 1-71.
Godet J.L. \& Guillemot M.L., 1998. Conséquences de la nouvelle directive européenne relative à la qualité des eaux destinées à la consommation humaine. Proceedings of International Ozone Regional Conference. Poitiers France, 23-25 September 1998, pp. 1-1 - 1-13.

Goldstein D., Wei I. \& Casana J., 1987. Wastewater Reuse as Cooling-Tower Makeup, EPRI Research Project 126019, CS-5373.

Gordon G., Kieffer R.G. \& Rosenblatt D.R., 1972. The chemistry of chlorine dioxide. Prog. Inorganic Chem. 15, pp. 201286.

Gordon G. \& Bubnis B., 1997. Chlorine dioxide, chemistry and technology. In Chlorine dioxide and disinfection. Proceedings of "First European Symposium on Chlorine Dioxide and Disinfection". Rome 1996, November 7 8. Collana Ambiente, vol. 17, pp. 15-26.

Gosling E. (ed.), 1992. The mussel Mytilus, Ecology, physiology, genetics and culture. Developments in Aquaculture and Fisheries Science 25, Elsevier, Amsterdam, $590 \mathrm{pp}$.

Graham J.W., Stock J.N. \& Benson P.H. 1977. Further studies on the use of heat treatment to control biofouling in seawater cooling systems. IEEE Ocean'77, pp. 23A1-23A6.

Graney R.L., Cherry D.S., Rodgers J.H. \& Cairns J., 1980. The influence of thermal discharges and substrate composition on the population structure and distribution of the Asiatic clam, Corbicula fluminea, in the New River, Virginia. Nautilus 94, pp. 130-135.

Greenshield J.F. \& Ridley J.E.,1957. Some research on the control of mussels in water pipes. J. Inst. Wat. Engrs. II, pp. 300-306.

Gribble G.W., 1994. The natural production of chlorinated compounds. Environ. Sci. Technol. 7, pp. 310-318.

Griffiths J.S., 1992. Control of zebra mussels by thermal shock. Ontario Hydro 
report 92-65 K. Quoted in Claudi and Mackie, 1994.

Gross A.C., 1991. Evaluation of nonfouling coatings for power plant cooling water intake systems. In Proceedings of Condenser Technology Conference. EPRI. GS-7349, August 1991.

Gross A.C., 1996. Non-toxic foul-release coatings help utilities reduce costs for cooling-water intake systems. Innovators with EPRI technology. IN-100297, $2 \mathrm{p}$.

Gu Ji-Dong \& Mitchell R., 1997. Use of metabolites and natural products for zebra mussel control. Seventh International Zebra Mussel and Aquatic Nuisance Species Conference. New Orleans, Jan. 28-31.

Gunten U. von \& Hoigné J., 1994. Bromate formate during ozonation of bromidecontaining waters, interaction of ozone and hydroxyl radical reactions. Environ. Sci. Technol. 28, pp. 1234-1242.

Hall L.W., 1988. Tributyltin environmental studies in Cheasapeake Bay. Marine Pollution Bulletin, 19 (9), pp. 431-438.

Harada A., Sakata K., Ina H. \& Ina K., 1985. Isolation and identification of xanthatin as an anti-attaching repellent againts blue mussel. Agric. Biol. Chem. 49 (6), pp. 1887-1888.

Harper D.B., 1994. The contribution of natural halogenation processes to the atmospheric halomethane burden. In Int. Conf. on Naturally Produced Organohalogens 14-17 Sept. 1994 TNO Delft, pp. 3-4.

Harris R.R., 1991. Amphipod also invades Britain. Nature 354, pp. 194.

Hartmann-Schroeder, 1967. Zur Morphologie, Oekologie und Biologie von Mercierella enigmatica (Serpulidae, Polychaeta) und ihre Roehre. Zool. Anz. 179, pp. 421-456.

Hasson D., 1979. Precipitation Fouling. In, Somerscales and Knudson (eds) Fouling and Heat Transfer Equipment. Proc Conf Rensselar Polytechnic Institute
Troy, N.Y. 13-17 Aug. 1979, pp. 527568.

Heinle D.R., 1976. Effects of passage through power plant cooling systems on estuarine copepods. Environ. Pollut. 11 , pp. 39-58.

Hergott S.J., Jenkins D. \& Thomas J.F., 1978. Power plant cooling water chlorination in Northern California. $J$ Water Pollut. Control. Fed. 50, pp. 2590-2601.

His E., 1995. Embryogenesis and larval development in Crassostrea gigas, experimental data and field observations on the effect of tributyltin compounds, in "Organotin", Champ \& Seligman (eds) Chapman \& Hall.

Hoekstra E.J. \& De Leer E.W.B., 1994. AOX levels in the River Rhine, pp. fifty percent of natural origin? Water. Sci. Technol. 29, pp. 133-136.

Hoestland H. \& Lassablière J. 1959. Destruction thermique de la moule d'eau douce. L'eau, 46, 11, pp. 259-262.

Hoestland H., 1972. Toxicité de deux molluscicides (Baylucide et Frescon) à l'égard de la moule d'eau douce (Dreissena polymorpha), Bulletin Français de Pisciculture, 244, pp. 104-110.

Hori M., Lizawa M., Kawabe A., Wakisaka Y. \& Ishiyama E., 1993. Application of a UV irradiation system for a power station intake. CEbalia, vol. XIX, suppl., pp. 395-403.

Hori M., Nagayama S., Kawabe A. \& Yamashita K., 1990. Influence of UV irradiation on the nauplius larvae of the barnacle Chthamalus sp., suppl. Denki Kagaku, vol. 58, n 7, pp. 629-637.

Hose J.H., Di Fiori D., Parker H.S. \& Sciarrotta T., 1989. Toxicity of chlorine dioxide to early life stage of marine organisms. Bull Environ. Contam. Toxicol. 42, pp. 315-319.

Humphris T.H., 1979. The control of phosphate scaling in power station condensers. In Somerscales and Knudson (eds) Fouling and Heat Transfer Equipment Proc. Conf. Rensselar Polytech- 
nic Institute Troy, N.Y. 13-17 Aug 1979, pp. 603-616.

Isnard P. \& Lambert S., 1988. Estimating bioconcentration factors from octanolwater partition coefficient and aqueous solubility. Chemosphere, vol. 17, 1, pp. 21-34.

Iwanyzki S. \& McCauley R.W., 1993. Upper lethal temperatures of adult zebra mussels (Dreissena polymorpha). In: Nalepa T.F., Schloesser D.W. (eds) Zebra mussels, biology, impacts and control. Lewis Publishers, London, pp. 667-676.

Jantz B. \& Neumann D., 1992. Shell growth and aspects of the population dynamics of Dreissena polymorpha in the River Rhine. In: Neumann D and Jenner HA (eds) The Zebra Mussel Dreissena polymorpha Gustav Fischer Verlag, Limnologie aktuell 4. pp. 4966.

Jenner H.A., 1982. Physical methods in the control of mussel fouling in seawater cooling systems. La Tribune du CEBEDEAU, 33, pp. 13-19.

Jenner H.A., 1985. Chlorine minimization in macrofouling control in the Netherlands. In : Water Chlorination Environmental Impact and Health Effects, Jolley et al. (eds) Ann Arbor Sci. Vol. 5, pp. 1425-1433.

Jenner H.A., Taylor C.J.L., Van Donk M. \& Khalanski M., 1997. Chlorination byproducts in chlorinated cooling water of some European Coastal Power Stations. Marine Environmental Research, vol. $43, N^{\circ} 4$, pp. 279-293.

Jenner H.A., 1983. A microcosm monitoring mussel fouling, 11 p. In I.A. DiazTous, M.J. Miller, and Y.G. Mussalli [ed.] EPRI Symposium on Condenser Macrofouling Control Technologies, The State-of-the-Art, Hyannis, Massachusetts, June 1-3.

Jenner H.A., Janssen-Mommen J.P.M., 1993. Monitoring and control of Dreissena polymorpha and other macrofouling bivalves in The Netherlands. In, Nalepa TF, Schloesser DW (eds) Zebra mussels, biology, impacts and control. Lewis Publishers, London, pp. 537-555. Johnson J.D. \& Overby R., 1971. Bromine and bromamine disinfection chemistry. Am. Soc. Civil Engineers Proc J. Sanitary Eng. Div. 97, p. 617.

Johnson J.D. \& Sun W., 1975. Bromine disinfection of wastewater. In: JD Johnson (ed.) Disinfection, Water and Wastewater. Ann Arbor Science, Ann Arbor, Michigan, Chapter 9.

Johnson P.D. \& McMahon R.F., 1997. Oxygen deprivation as a control measure for zebra mussels and Asian clams, how should you go? Seventh International Zebra Mussel and Aquatic Nuisance Species Conference. New Orleans Jan. 28-31.

Jolley R.J., Brungs W.A., Cotruvo J.A., Cumming R.B., Mattica J.S. \& Jacobs V.A. (eds), 1983. Water chlorination, environmental impact and health effects. Vol. 4. Ann Arbor Science Publishers Michigan books, $1491 \mathrm{p}$.

Jolley R.L. (ed.), 1976. The environmental impact of water chlorination. Oak Ridge National Laboratory Tennessee USA, $443 \mathrm{p}$.

Jolley R.L., Brungs W.A., Cumming R.B., Jacobs V.A. (eds), 1980. Water chlorination, environmental impact and health effects. Vol. 3 Ann Arbor Science Publishers Michigan, $1171 \mathrm{p}$.

Jolley R.L., Bull R.J., Davis W.P., Katz S., Roberts Jr M.H., Jacobs V.A. (eds), 1986. Water chlorination, chemistry, environmental impact and health effects. Vol. 5. Lewis Publishers Inc Michigan, $1575 \mathrm{p}$.

Jolley R.L., Condie L.W., Johnson J.D., Katz S., Minear R.A., Mattice J.S., Jacobs V.A. (eds), 1990. Water chlorination, chemistry, environmental impact and health effects. Vol. 6. Lewis Publishers Inc Michigan, $1023 \mathrm{p}$.

Jolley R.L., Gorchev H., Heyward Hamilton D. (eds), 1978. Water chlorination, environmental impact and health effects. Vol. 2. Ann Arbor Science Publishers Michigan, $909 \mathrm{p}$. 
Kawabe A. 1997. Non-toxic biofouling control technologies. Japanese review.

Kawabe K., Yasui T., Ikeda N., Nishijima H. \& Yamamoto A. 1985. Effects of flow dynamics on attachment of marine organisms for copper and copper alloy seawater pipes. Denki Kagaru, $53 n^{\circ}$ 6. pp. 422-423.

Kelly M., 1988. Mining and the freshwater environment. Elsevier Applied Science - British Petroleum. 231 p.

Khalanski M. \& Bordet F., 1981. Modalité d'action du chlore sur la moule marine. $2^{\mathrm{e}}$ Journées de la Thermo-écologie. Institut Scientifique et Technique des Pêches Maritimes, 14-15 Novembre 1979, pp. 745-7.58.

Khalanski M., 1985. Impact de la chloration sur la qualité de l'eau et le plancton. Bilan des études réalisées sur le site de Gravelines de 1979 à 1983. Report EDF DER HE/31-85.09, 70 pp.

Khalanski M. \& Lutz Ph., 1987. La chloration de l'eau de réfrigération. Revue Générale Nucléaire, $n^{\circ} 1$. pp. 52-58.

Khalanski M., 1993. Testing of five methods for the control of zebra mussels in cooling circuits of power plants located on the Moselle river. Proceedings, Third International Zebra Mussel Conference, Toronto 1993. EPRI Report TR-102077. June 1993, pp. 3.13.20 .

Khalanski M. \& Delesmont R., 1994. Résiduels de chloration en mer à Penly. Report EDF DER HE/31-94.020, 52 $\mathrm{pp}$.

Khalanski M., 1995. La chloration discontinue des circuits de réfrigération en eau de mer. Report EDF DER HE/3195.05., $39 \mathrm{pp}$.

Khalanski M. \& Gras R., 1996. Rejets thermiques en rivières et hydrobiologie. Un aperçu sur l'expérience française. La Houille Blanche. $\mathrm{N}^{\circ}$ 5, pp. 13-18.

Khalanski M., 1997a. Zebra mussel and other invasive species in cooling water circuits of French Power stations on rivers. Seventh International Zebra Mus- sel \& Aquatic Nuisance Species Conference. New-Orleans, Jan. 28-31.

Khalanski M., 1997b. Conséquences industrielles et écologiques de l'introduction de nouvelles especes dans les hydrosystèmes continentaux, la moule zébrée et autres espèces invasives. Bull. Fr. Pêche Piscic. 344/345, pp. 385-404.

Khalanski M., 1997c. Data on the toxic effects of the anti-corrosion product Mexel 432 on fresh water organisms. EDF. DER. Report HE/31-97-016, 42 pp.

Kinne O., 1956. Über den Einfluss des Salzgehaltes und der Temperatur auf Wachstum, Form und Vermehrung bei dem Hydroidpolypen Cordylophora caspia (Pallas), Thecata, Clavidae. Zool. Jahrb. Abt. Allg. Zool. Physiol Tiere 66 , pp. 565-638.

Kinzelbach R., 1992. The main features of the phylogeny and dispersal of the Zebra mussel Dreissena polymorpha In: Limnologie aktuell 4, Neumann D. and Jenner H.A. (eds). The Zebra Mussel Dreissena poylmorpha, Gustav Fischer Verlag, pp. 5-18.

Kirpichenko M.Y., Mikheev V.P. \& Stren E.P., 1962. Lutte contre la prolifération des Dreissena dans les centrales hydroélectriques (in Russian). Elektichesskie Stantsii, 5, pp. 30-32.

Klain S.J., Cobb G.P., Dickerson D.L., Dixon K.R., Kendall R.J., Smith E.E. \& Solomon K., 1996. An ecological risk assessment for the use of the biocide, dibromonitrilopropionamide (DBNPA), in industrial cooling water systems. Environmental Toxicology and Chemistry, 15, pp. 21-30.

Klerks P., \& Fraleigh P., 1991. Control of adult Zebra mussels with sodium hypochlorite, potassium permanganate and hydrogen peroxide with iron. Abstract Zebra Mussels Mitigation Options for Industries. Toronto, Ontario.

Kovalac W.P., Longton G.D. \& Smithee R.D., 1993. Infestation of Power Plant water systems by the Zebra mussel. 
(Dreissena polymorpha). In: Zebra Mussels Biology, Impacts and Control. Nalepa T.F. \& Schloesser D.W. (eds.) Lewis Publishers, London, pp. 359380.

Kramer J.F., 1997. Peracetic acid, a new biocide for industrial water applications. MP/August, pp. 42-50.

Krzeminski S.F., Brackett C.K. \& Fisher J.D., 1975a. Fate of microbicidal 3-isothiazolone compounds in the environment, modes and rates of dissipation. J. Agric. Food Chem., vol. 23, 6, pp. 1060-1067.

Krzeminski S.F., Brackett C.K. \& Fisher J.D., 1975b. Fate of microbicidal 3-isothiazolone compounds in the environment, products of degradation. J. Agric. Food Chem., vol. 23, 6, pp. 1068-1075.

Lagouche A. \& Guillon A., 1976. Protection des conduites d'eau de mer contre l'envahissement par la flore et la faune marine. TSM L'EAU, n 5, pp. 197-210.

Langford T.E., 1983. Electricity generation and the ecology of natural waters. Liverpool Univ. Press, $342 p$.

Langford T.E., 1990. Ecological effects of thermal discharges. Elsevier Appl. Sci., $468 \mathrm{p}$.

Langlais B., Legube B., Beuffe H. \& Doré M., 1992. Study on the nature of byproducts formed and the risk toxicity when disinfecting a secondary effluent with ozone. Wat. Sci. Techn. vol. 25, $\mathrm{N}^{\circ}$ 12, pp. 135-143.

Lassus P., Maggi P., Le Baut C., Bardouil M., Bocquene G., Le Dean L. \& Truquet, 1981. Influence de la chlorination sur les premiers stades larvaires de Palaemon serratus (Pennant). Unpublished report of the Institut Scientifique et Technique des Pèches Maritimes.

Lauer T.E., Spacie A. \& Barnes D.K., 1997. Competitive interactions between Dreissena polymorpha (Bivalvia) and Lophodopodella carteri (Bryozoa) in a southern Lake Michigan harbor. Communication at the Seventh International
Zebra Musel and aquatic Nuisance Species Conference., New-Orleans, Jan. 28-31.

Lecœuvre J.-M., Caytan Y. \& Granges J.L., 1986. Des aéroréfrigérants performants. Epure. EDF DER publ. $\mathrm{N}^{\circ} 9$ Janvier 1986, pp. 43-57.

Lefebvre E. \& Deguin A., 1997. Chlorine dioxide, use in a drinking water process. In Chlorine dioxide and disinfection. Proceedings of "First European Symposium on Chlorine Dioxide and Disinfection". Rome 1996, November 78. Collana Ambiente, vol. 17, pp. 105118.

Leglize L. \& Ollivier F., 1981. Mise au point bi-bliographique sur la biologie et l'écologie de Dreissena polymorpha PALLAS (1771). répartition géographique en France et dans les pays limitrophes. EDF/DER Report HE/31-81.37.

Leitch E.G., 1994. Evaluation of coatings to control zebra mussel colonization. Final report. Ontario Hydro Rept. 93/236/K.

Lepage W.L.,1993. The impact of Dreissena polymorpha on waterworks operations at Monroe Michigan. A case history. In : Zebra Mussels Biology, Impacts and Control. Nalepa T.F. \& Schloesser D.W. (eds) Lewis Publishers, London, pp. 333-358.

Lewis B.G., 1961. Biological observations made during trials of chlorination for mussel control at East Yelland 1959 to 1960 CERL Report No RD/LR 1052.

Lewis B.G., 1983a. Development of a preliminary model to predict time in days for $100 \%$ kill of mussels subject to continuous chlorination CERL Note No TPRD/L2469/N83.

Lewis B.G., 1983b. Effects of continuous chlorination on mussels and validation of preliminary model CERL Note No TPRD/L/2594/N83.

Lewis B.G., 1985. Mussel control and chlorination CERL Report No TPRD/ L2810/R83. 
Lewis R.O., 1982. The influence of biofouling counter-measures on corrosion of heat exchanger materials in seawater. Material performance, pp. 31-38.

Lewis D. \& Pawson R.L., 1993. Use of cathodic protection as a means of control and removal of zebra mussels. Communication at International Zebra Mussel Conference. Toronto.

Lewis D., Pawson R. \& Pickles S.B., 1997a. Electrolytic protection for zebra mussel control on concrete walls of an operating pump well, a pilot sludy. Communication at Seventh International Zebra Mussel and Aquatic Nuisance Species Conference. New Orleans.

Lewis D.P., Butts D. \& Cressiwell R., $1997 b$. Control of zebra mussels in fire protection systems using commerciallyavailable potash. Seventh International Zebra Mussel and Aquatic Nuisance Species Conference. New Orleans Jan. 28-31.

Leynen M., Ollivier F., Duvivier L. \& Van Damme A., 1997. Mitigation of macrofouling, $\mathrm{pp}$. a comparative study of ozone and an organic filminducing polymer. Communication at the Seventh International Zebra Musel and aquatic Nuisance Species Conference., NewOrleans, Jan. 28-31.

Lincoln R.J., 1979. British marine Amphipoda: Gammaridae. Brit. Mus. (Nat. Hist.) Lond., p. 658.

Lovegrove T. \& Robinson T.W. 1968. The prevention of fouling by localized chlorine generation. Biodeterioration, $p$. 617.

Lubet L., 1983. Experimental studies on the action of temperature on reproductive activity of the mussel (Mytilus edulis L. Mollusca Lamellibranchia). J. Moll. Stud. suppl. 12A, pp. 100-105.

Lutz P. \& Merle G., 1983. Discontinuous mass chlorination of natural draft cooling towers. Wat. Sci. Tech. 15, pp. 197213.
Lykins B.W. \& Griese M.H., 1986. Using chlorine dioxide for trihalomethane control. Journ. AWWA 6, pp. 88-93.

Lynn J.W., Barre A., Smith S., Misamore M., Dietz T.D. \& Silverman H., 1997. Ion requirements for fertilization and early cleavage events in Dreissena polymorpha. Seventh International Zebra Mussel and Aquatic Nuisance Species Conference. New Orleans.

Lyons L.A., Petrille J.C., Donner S.P., Fobes R.L., Lehmann F., Althouse P.W., Wall L.T., Post R.M. \& Buerger W.F., 1990. New treatment employing a molluscicide for macrofouling control of zebra mussels in cooling systems. American Power Conference, Chicago, April 23-25.

Lyons L.A., Petrille J.C., Werner M.W., Bidwell J.R. \& Cherry D.S., 1991. An on-site evaluation of zebra mussel control, comparing chlorine, bromine and a non-oxidizing molluscicide. EPRI Zebra Mussel Control Technology Conference. Oct. 22-23.

Madeley J.R., 1973. The acute toxicity of hydrocarbons to fish. A review of the work carried out at the Brixham Laboratory to June $1973 \mathrm{ICI}-\mathrm{BL} / \mathrm{B} / 1521$.

Mantisi F., Gautier J.P. \& Dernat M., 1997. A simple robust method for the determination of chlorine dioxide in drinking water. In Chlorine dioxide and disinfection. Proceedings of "First European Symposium on Chlorine Dioxide and Disinfection". Rome 1996, November 7-8. Collana Ambiente, vol. 17, p. 39.

Marchand J. \& Denayer J.C., 1991. Spatio-temporal comparisons of the development of fouling communities in the Loire Estuary (France). In: Elliott $M$. and Ducroty J.P. (eds), Estuaries and Coasts, pp. Spatial and Temporal Intercomparisons. Int Symp Series 1991 Univ. of Caen France, pp. 265-271.

Marcos F. \& Gailhard J., 1994. Centrale de Penly. Modélisation tridimensionnelle des rejets chlorés. Report EDF/DER. HE/42-94.055/A., 59 pp. 
Marelli D.C. \& Gray S., 1983. Conchological redescriptions of Mytilopsis sallei and Mytilopsis leucophaeta of the brackish western Atlantic. Veliger 25, pp. 185-193.

Markowski S., 1962. Faunistic and ecological investigations in Cavendish Dock, Barrow in Furness J. Anim. Ecol. 31, pp. 43-52.

Martin I.D., Baker M.A. \& Mackie G.L., 1990. Comparative efficacies of sodium hypochlorite and registrered biocides for controlling the Zebra mussel Dreissena polymorpha (Bivalve Heterodonta). Abstr. Zebra mussels: The Great Lakes experience, University of Guelph, Guelph Ontario. From Van Benschoten et al., 1992.

Masschelein W., 1979. Chlorine dioxide, Chemistry and impact of oxichloride compounds. Ann Arbor Science, Ann Arbor MI.

Matisoff G., Brooks G. \& Bourland I.B., 1996. Optimizing treatment processes of chlorine dioxide to adult mussels. Journal AWWA. August 1996, pp. 93106.

Mattice J.S. \& Zittel H.E., 1976. Site-specific evaluation of power plant chlorination. J. Water Pollut. Control Fed. 48(10), pp. 2284-2308.

Mattice J., 1983. Freshwater macrofouling and control with emphasis on Corbicula. In : Condenser Macrofouling Control Technologies, pp. The State of the Art. Tous I.A.D., Miller M.J., Mussali YG (eds) Hyannis, Mass. USA 1-3 June 1983 EPRI.

Mayack L.A., Coracco R.J., Wilde E.W. \& Pope D.H., 1984. Comparative effectiveness of chlorine and chlorine dioxide biocide regimes for biofouling control. Wat Res. 18, pp. 593-599.

McCoy W.F., Blatchley III E.R. \& Johnson R.W., 1990. Hapohalous acid and haloamine falsoff in industrial evaporative cooling systems. Cooling tower institute 1990 annual meeting. Technical paper number TP90-09.
McLean R.I., 1973. Chlorine and temperature stress on selected estuarine invertebrates. Am. Zool. J. Wat. Poll. Cont. Fed. 45, pp. 837-841.

McMahon R.F., 1983. Ecology of an invasive pest bivalve corbicula. In The Mollucs, Hunter W.D.R. (ed.), vol. 6. Ecology. Academic Press, New-York, pp. 501-561.

McMahon R.F. \& Tsou J.L., 1990. Impact of European Zebra Mussel infestation to the electric power industry. Annual Meeting of the American Power Conference, April 23-25 1990, Chicago (USA), $10 \mathrm{pp}$.

McMahon R.F., Shipman B.N. \& Erck D.E., 1990. Effects of two molluscicides on the freshwater macrofouling bivalve Dreissena polymorpha, the zebra mussel. Annual Meeting American Power Conference, Chicago, April 23-25, 6 p.

McMahon R.F., Ussery T.A. \& Miller A.C., 1993. Thermal tolerance in zebra mussels (Dreissena polymorpha) relative to temperature increase and acclimatation temperature. Third International Zebra Mussel Conference. Toronto, Canada, Feb. 1993.

Merkens J.C., 1958. Studies on the toxicity of chlorine and chloramines to the rainbow trout. Water and Waste Treat. Jour. 7, pp. 150-151.

Merle G. \& Montanat M., 1980. Essai d'utilisation du dioxyde de chlore dans la boucle TERA installée à Montereau. Résultats des tests d'efficacité. EDF DER Report HE/31-80.045.

Mollica A., Alabiso G., Scotto V., Traverso E. \& Ventura G., 1988. "Influence of biofouling on active-passive alloys in sea water" (in Italian). Congress Corrosione Marina, Genova.

Mollica A., Traverso E. \& Ventura G., 1990. Electrochemical monitoring of the biofilm growth on active-passive alloy tubes of heat exchange using sea water as cooling medium, XI Proceedings of International Corrosion Congress, Firenze 2-6 April 1990, Italy, AIM Ed., vol. 4, pp. 333-340. 
Mollica A. \& Ventura G., 1993a. Proceedings of 8 th Int. Cong. on Marine Corrosion and Fouling, 1992, Taranto (Italy), "Oebalia", vol. 19, pp. 313, 322.

Mollica A. \& Ventura G., 1993b. Proceedings of 12th Int. Corr. Cong., Houston, TX, U.S.A., NACE Int., vol. 5B, pp. 3807-3812.

Mollica A., Ventura G., Andrei E., Cristiani P. \& Rocchini G., 1996. "Simple Electrochemical Devices for Biofilm Monitoring on Stainless Steels in Seawater", Proceedings of EUROCORR '96', September 24-26, 1996, Nice (France).

Molloy D.P., Fokin S., Laruelle F.H. \& Lynn D.H., 1997. Ophryoglenine Ciliates parasitizing zebra mussels. Seventh International Zebra Mussel and Aquatic Nuisance Species Conference. New Orleans, Jan. 28-31.

Montanat M., Merle G., and Migeon B., 1980. Essai d'utilisation du dioxyde de chlore dans la boucle TERA installée à Montereau. Résultats des tests de toxicité. EDF DER Report HE/31. 80.044 .

Moreteau J.C. \& Khalanski M., 1994. Settling and growth of $D$. polymorpha in the raw water circuits of the Cattenom Nuclear power plant (Moselle, France) 4th Int Zebra Mussel Conf. Madison Wisconsin Mars 1994 (EDF/DER rapport HE 31/94/012.

Morris J.C., 1978. Chemistry of aqueous chlorine in relation to water chlorination Chapter 2 In: R.L. Jolley (ed.) Water Chlorination, Environmental Impact and Health Effects. Volume 1, Ann Arbor Science, Ann Arbor, Michigan.

Morton B., 1979. Freshwater fouling bivalves, pp. 1-14 In: Britton J.C. (ed.) Proc. First Int. Corbicula Symp. Texas Christian Univ., Fort Worth, Texas, USA $313 \mathrm{pp}$.

Morton B., 1983. The sexuality of Corbicula fluminea (Muller) in lenthic and lothic waters in Hong Kong. J. Moll. Stud. 49 , pp. 81-83.
Morton B., 1986. Corbicula in Asia-an updated synthesis. Am. Malacol. Bull. Spec. ed. No 2, 113-124.

Mouthon J., 1981. Sur la presence en France et au Portugal de Corbicula (Bivalvia, Corbiculidae) originaire d'Asie. Basteria 45, pp. 109-116.

Mowery D., McClellan E., Lyons L.A., Austin D.M. \& Karlovich D.M., 1989. Asiatic clam control experience at Peach Bottom atomic power station. EPRI Service Water Systems Reliability Improvement. Charlotte, North Carolina, $6 \mathrm{p}$.

Muia R.A., McGough C.M. \& Gill P.H., 1993. Effects of temperature on a nonoxidizing biocide being applied for Mollusk control. Calgon Bulletin $\mathrm{N}^{0} 11, \mathrm{p}$. 612.

Mussali Y.G., Hecker G., Padmanabhan M., Kasper J. \& Chow W., 1985. Targetted chlorination. Condenser Biofouling Control Symposium: The state of the art. June 1985. Lake Buena Vista, Florida. EPRI Report, 27 pp.

Mussali Y.G., 1988. Biofouling control at water intake structures. Journal of Hydraulic Engineering, vol. $114 \mathrm{n}^{\circ} 6, \mathrm{pp}$. 616-625.

Nakayama S., Shinio, Claudi R. \& Evans D., 1997. Use of intermittent application of ozone for biofouling and zebra mussel control. Communication at the Seventh International Zebra Musel and aquatic Nuisance Species Conference, New-Orleans, Jan. 28-31.

Nalepa T.F. \& Schloesser D.W. (eds), 1993. Zebra mussels, biology, impacts and control. Lewis Publishers, London, $810 \mathrm{pp}$.

Nancollas G.H. \& Reddy M.M., 1976. Crystal Growth Kinetics of Minerals Encountered in Water Treatment Processes. In: Aqueous-Environmental Chemistry of Metals Rubin A.J. (ed.). Ann Arbor Science Publishers, Ann Arbor.

Neumann D. \& Jenner H.A. (eds), 1992. The Zebra Mussel Dreissena polymor- 
pha. Limnologie aktuell 4, Gustav Fischer Verlag, $262 \mathrm{pp}$.

Nosetani T., Sato S., Onda K. \& Kato Y., 1989. Biofouling control of titanium condenser tubes by new-type abrasive sponge balls. ASME, National Heat Transfer Conference, HTD Vol. 108, pp. 281-288.

Okubo K. \& Okubo T., 1962. Study on the bioassay method used for the evaluation of water pollution II Use of fertilised eggs of sea urchins and bivalves. Bull Tokai Reg. Fish. Res. Lab. 32, pp. 131-140.

Oliver P.G., Holmes A.H. \& Mettam C., 1998. Mytilopsis leucophaeta, (Conrad, 1831) [Bilvalvia : Dreissenoidea] species new to the British fauna. J. Conch. 36 (2) : pp. 13-18.

Osborn D.W., 1970. Factors affecting the use of purified sewage effluent for cooling purposes. Water Pollut. Contr., 69(4), pp. 456-464.

Ottaviani M., 1997. Evolution of EC Direclives and regulations for drinking water, disinfection issues. In Chlorine dioxide and disinfection. Proceedings of "First European Symposium on Chlorine Dioxide and Disinfection". Rome 1996, November 7-8. Collana Ambiente, vol. 17, pp. 73-82.

Palin A.T., 1957. The determination of free and combined chlorine in water by use of diethyl-p-phenylenediamine. J. Amer. Water Works Assoc. 49, pp. 873.

Palin A.T., 1967. Methods for determination, in water, of free and combined available chlorine, chlorine dioxide and chlorite, bromine, iodine, and ozone using diethyl-p-phenylenediamine (DPD). J. Inst. Water Eng. 21, p. 537.

Palin A.T., 1975. Current DPD methods for residual halogen compounds and ozone in water. J. Amer. Water Works Assoc 67, pp. 32.

PARCOM, 1995. Report on the workshop on products containing or generating organohalogen compounds. Oslo and Paris Conventions for the Prevention of
Marine Pollution Working Group on Diffuse Sources (DIFF), Bremen, 10-13 October 1995.

Parent J.-F., Monfort J., 1985. Seashore power stations and protection of the marine environment. EDF DER Report HE/42/82/85/18, $43 \mathrm{p}$.

Petrille J.C. \& Werner M.W., 1993. A combined treatment approach using a nonoxidizing molluscicide and heat to control zebra mussels. Third International Zebra Mussel Conference. Toronto, Ontario. Feb. 23-26.

Piccirillo V.J., Malik N., Van Dresar W. \& Flood T., 1994. TD 2335, Laboratory and field efficacy studies for control of zebra Mussels in electric power plants. Fourth International Zebra Mussel Conference. Madison, Wisconsin. EPRI TR-104029, Proceedings, pp. 111-118.

Piccirillo V.J., Sandberg G., Fobell J. \& MC Allister D., 1995. TD 2335, Field efficacy studies for control of Zebra Mussels on electric power plants. Fifth International Zebra Mussel and Aquatic Nuisance Organisms Conference. Toronto, Feb. 21-24.

Plessis-Fraissard Y., 1961. Écologie de l'estran rocheux du Calvados, pp. étude des biocénoses et recherches expérimentales. These Université de Paris. 29 Juin 1961. A. $N^{\circ} 3698,4549$.

Poje G.V., Riordan S.A., O'Connor J.M., 1981. Power plant entrainment simulation utilizing a condenser tube simulator. US Nuclear Regulatory Commission Report NUREG/CR-2091 RE, 25.

Prezant R.S. \& Chalermwat K., 1984. Floatation of the bivalve Corbicula fluminea as a mean of dispersal. Science Proceedings 225, pp. 1491-1493.

Proceedings of the First International Zebra Mussel Conference. 1991.

Proceedings of the Second International Zebra Mussel Conference. Toronto Ontario. 1992.

Proceedings of the Third International Zebra Mussel Conference. Toronto Ontario. 1993. EPRI Report TR-102077. 
Proceedings of the Fourth International Zebra Mussel Conference. Madison Wisconsin 1994, Wisconsin Sea Grant Institute.

Proceedings of the Fifth International Zebra Mussel and Other Aquatic Nuisance Organisms Conference, 1995, Toronto Ontario.

Proceedings of the Sixth International Zebra Mussel and Other Aquatic Nuisance Organisms Conference, 1996, Dearborn.

Proceedings of the Seventh International Zebra Mussel and Other Aquatic Nuisance Organisms Conference, 1997. New-Orleans.

Puckorius P.R. \& Strauss SD., 1995. Cooling water treatment. Power, May 1995.

Puckorius P.R., 1997. Cooling tower fill water quality/operations guidelines to successful utilization. In Proceedings of Cooling Tower Technology Conference. EPRI TR-108483.2113. July 1997, pp. 3-1 - 3-13.

Rainbow P.S., 1984. An introduction to the biology of British littoral barnacles. Field Studies 6, pp. 1-51.

Rajagopal S., Van der Velde G. \& Jenner H.A., 1997. Response of zebra mussel, Dreissena polymorpha, to elevated temperatures in the Netherlands. In: Zebra mussels and aquatic nuisance species (Frank d'Itri Ed.) Ann Arbor Press, Inc. Michigan, pp. 257-273.

Rajagopal S., Van der Velde G., Jenner H.A., 1994. Biology and control of brackish water mussel, Mytilopsis leucophaeta in the Velsen and Hemweg power stations, The Netherlands. Part II. Control measures. Report No 163871-KES/WBR 94-3128, KEMA Environmental Research, $45 \mathrm{p}$.

Rajagopal, S., Nair, K.V.K., Van der Velde, G. \& Jenner H.A., 1997. Response of mussel Brachidontes striatulus to chlorination : an experimental study. Aquat. Toxicol. 39, pp. 135-149.

Rajagopal S., Van der Velde G., Paffen B.G.P., 1999a. Growth and reproduc- tion of Corophium curvispinum G.O. Sars, 1895 (Amphopoda), an invader in the Lower Rhine. Crustaceana. (in press).

Rajagopal S., Van der Velde G., Paffen B.G.P., Van den Brink F.W.B. \& Bij de Waate A., 1999b. Life history and reproductive biology of the invasive amphipod Corophium curvispinum (Crustacea: Amphipoda) in the Lower Rhine. Arch. Hydrobiol. 144(3), pp. 305325.

Ramsey, G.G., Tackett J.H. \& Morris D.W., 1988. Effect of low-level continuous chlorination on Corbicula fluminea. Environ. Toxicol. Chem. 7, pp. 855-856.

Rao N.M., Lu F.Y., Johnson D.A. \& Nghiem J.P., 1997. Understanding armatic triazole consumption in utility cooling towers and development of an environmentally friendly yellow metal corrosion inhibitor. In Proceedings of Cooling Tower Technology Conference. EPRI TR-108483.2113. July 1997, pp. 3-79 - 3-97.

Rauh J.S., 1979. Disinfection and oxidation of waste water by chlorine dioxide. J. Envir. Sci 22, pp. 42-45.

Ray D.L., 1959. Marine Boring and Fouling Organisms Friday Harbor Symposium. Univ Washington Press, 536 p.

Relini G. \& Bianchi C.N., 1979. Prime osservazioni sul fouling della centrale termoelettrica di Torvaldaliga (Civitavecchia). Atti XI Congr. S.I.B.M., Orbetello/Atti Soc. Tosc. Sci. Nat. Mem. ser. V., 86 suppl., pp. 308-311.

Relini G. \& Romaiore V., 1976. Cicli di insediamento del fouling in condotte di un impianto di raffreddamanto con acqua di mare. Arho Oceanogr. Limnol., 18 (3), pp. 231-256.

Relini G., 1984. Three years investigation on macrofouling of a Tyrrhenian power station. Proc. 6th Int. Congr. on Mar. Corr. and Fouling. Athens. Marine Biology, pp. 195-210.

Relini G., 1993. Mediterranean macrofouling. Oebalia, vol. 19, pp. 103-154. 
Relini G., Bianchi C.N. \& Pisano E., 1980. Macrofouling in the conduit of a middle Thyrrhenian power station. Proc. 5th Int. Congr. on Mar. Corr. and Fouling, Barcelona. Biologia Marine, pp. 279292.

Rice R.P. \& Wilkes J.F., 1992. Fundamental aspects of ozone chemistry in recirculating cooling water systems data evaluation needs. Ozone Sci \& Engineer.

Richardson S.D., 1997. Disinfection byproducts, identification and future regulations. In: Chlorine dioxide and disinfection. Proceedings of "First European Symposium on Chlorine Dioxide and Disinfection". Rome 1996, November 7-8. Collana Ambiente, vol. 17, pp. $51-60$.

Rikken G.B. Kroon A.G.M. \& Kengen S.W.M., 1996. Transformation of perchlorate into chlorite by a newly isolated bacterium, reduction and dismutation. Appl. Microbiol. Biotechnol. 45, pp. 420-426.

Ritchie J., 1927. Report on prevention of growth of mussels in sub-marine shafts and tunnels at Westbank Electric Station. Portobello Trans. Roy. Scottish. Soc. of Arts.

Roch M., Noonan P. \& LcCarter J.A., 1986. Determination of no effect levels of heavy metals for rainbow trout using hepatic metallothionein. Water Research, vol. 20, $\mathrm{n}^{\circ}$ 6, pp. 771-774.

Rook J.J., 1974. Formation of haloforms during chlorination of natural waters. Water Treat. Exam. 23, pp. 234-243.

Saroglia M.G., Scarano G., 1974. Risk from residual chlorine in cooling waters used for aquacultural purposes. Presented at the 4th Conference on Water Chlorination R. Jolley (ed.), Pacific Grove, oct. 1974, Risks, Issues and Answers, pp. 1437-1445.

Sarunac N., Guida V., Weisman R. \& Zhang Z. 1994. Integration of macrobiofouling control methods into an effective macrobiofouling control strategy.
Proceedings Condenser Technology Conference. EPRI Report TR-103475, pp. $3.39-3.68$

Schloesser D.W., Bij de Vaate A., Zimmerman A., 1994. A bibliography of Dreissena polymorpha in European and Russian Waters, 1964-1993. J. Shellfish Res. 13, pp. 243-267.

Schneider R. 1997. Generation of chlorine dioxide. In Chlorine dioxide and disinfection. Proceedings of "First European Symposium on Chlorine Dioxide and Disinfection". Rome 1996, November 78. Collana Ambiente, vol. 17, pp. 27-37.

Schoenbach K.H., Abou-Ghazala A., Alden R.W., Turner R. \& Fox J.T., 1997. Biofouling prevention with pulsed electric fields. Communication at Seventh International Zebra Mussel and Aquatic Nuisance Species Conference. New Orleans.

Schroenig G.P., Bisinger E.C., Laplante B.T. \& Gill P.H., 1995. Environmental fate of a non-oxidizing molluscicide. Oral presentation at the Fifth International Zebra Mussel Conference. Toronto. Ontario.

Schuler V.J. \& Larson L.E., 1974. Experimental studies evaluating aspects of fish behaviour as parameters in the design of generating station systems. Amer. Soc. Civil Eng. Wat. Res. Eng. Prog, Los Angeles, CA, USA.

Seed R. \& Suchanek H., 1992. Population and Community Ecology of Mytilus, Chap 4, pp. 87-169. In Gosling E. (ed.) The mussel Mytilus: ecology, physiology, genetics and culture. Elsevier, $589 \mathrm{p}$.

Seltzer-Hamilton E.M., Magee J.A., Wright D.A. \& Kennedy V.S., 1995. Laboratory culture of Dreissena polymorpha and Dreissena bugensis from fertilization to F1 juveniles using estuarine algae. Fifth International Zebra Mussel and Aquatic Nuisance Organisms.Conference. 21-24 Feb.1995. Toronto, Ontario, Canada.

Serli N., Claudi R., Lewis D. \& Pawson R., 1994. Use of cathodic protection for 
control of zebra mussel biofouling on steel and concrete surfaces. Communication at the Fourth International Zebra Mussel Conference. Madison, Wis, USA.

SETAC (Society of Environmental Toxicology and Chemistry), 1994. Final Report, Aquatic risk assessment and mitigation dialogue group. Pensacola, FI, USA.

Sheide J.I., 1997. Effect of niclosamide on adult zebra mussels (Dreissena polymorpha). Seventh International Conference Zebra Mussel and aquatic Nuisance Species. New-Orleans Jan. 28-31.

Siclet F., 1991. Colonisation des réfrigérants atmosphériques par les algues. Effet sur la stabilité du refrigérant et sur le colmatage du circuit de refroidissement. Rapport EDF/DER HE/31-91-14. $44 \mathrm{p}$.

Siddall S.E., 1980. Early development of Mytilopsis leucophaeata (Bivalvia, Dreissenacea). Veliger 22, pp. 378-379.

Sladeckova A., 1969. Control of slimes and algae in cooling systems. Verh. Int. Ver. Limnol. 17, pp. 532-538.

Smythe G.A., Lange C.L. \& Sawyko P.M., 1997. Evaluation of an On-line magnetic device as a control method for adults and settlement-stage mussels (Dreissena spp.). Communication at Seventh International Zebra Mussel and Aquatic Nuisance Species Conference. New Orleans.

Sprung M., 1987. Ecological requirements of developing Dreissena polymorpha eggs. Arch Hydrobiol., Suppl. 79, pp. 69-86.

Sprung M., 1989. Field and laboratory observations of Dreissena polymorpha larvae: abundance, growth, mortality and food demands. Arch. Hydrobiol. 115, pp. 537-561.

Sprung M., 1992. Observations on shell growth and mortality of Dreissena polymorpha in lakes. In The zebra mussel Dreissena polymorpha, Neuman D. \&
Jenner H.A. (eds), Limnologie Aktuell, 4, pp. 19-28.

Srikanth S. \& Berk S.G., 1994. Adaptation of Amoebae to Cooling Tower Biocides. Microb. Ecol. 27, pp. 293-301.

Standard Methods for the Examination of Water and Wastewater., 1992. Greenberg A.E., Clesceri L.S., Eaton A.D. (eds).

Stewart M.E., Blogoslawski W.J., Hsu R.Y. \& Helz G.R., 1979. By-products of oxidative biocides, toxicity to oyster larvae. Mar. Pollut. Bull. 10, pp. 166-169.

Straughan D., 1971. Establishment of nonbreeding population of Mercierella enigmatica (Annelida, Polychaeta) upstream from a breeding population. Bull. South. Calif. Acad. Sci. 69, pp. 169-175.

Sugam R., 1985. Chlorine minimization, dechlorination and ozonation. A case study. Proceedings of Condenser Biofouling Control Symposium, June 1820. Lake Buena Vista, Florida. EPRI Report, Session III, 16 pp.

Swinnen M., 1995. Milieu als drijfveer voor ontwikkelingen in koelwater technologieën. In “Watersymposium 1995 » organised by NACE Benelux.

Tabak H.H., 1981. Biodegradability studies with organic priority poltutant compounds. J. Water Poll. Control Fed. 53, pp. 1503-1518.

Ten Hove H.A. \& Hurk van den P., 1993. A review of recent and fossil serpulid reefs; actuopalaeontology and the Upper Malm serpulid limestones in NW Germany. Geol. Mijnbouw 72, pp. 2367.

Testard P., 1990. Eléments d'écologie du lamellibranche invasif Dreissena polymorpha Pallas. Étude de la dispersion des larves en région parisienne et de leur fixation. Réponse à la désoxygénation de l'eau. Thèse des Sciences Univ. Paris, 358 pp.

Thome J.-P., Marneffe Y., Brene C. \& Louvet M., 1989. Les Bryozoaires dans les centrales nucléaire de Tihange II et III, 
développement de techniques d'élimination. Rapport Université de Liège, non référencé, $44 \mathrm{pp}$.

Thompson C., Carbonara J., Chow W. \& Syrett B., 1994. Advanced targeted chlorination design. EPRI Report TR103475, pp. 3.17 - 3.38

Trabalka J.R., Tsai S.C., Mattice J.S. \& Burch M.B., 1980. Effects on carp embryos and Daphnia pulex of chlorinated organic compounds produced during control of fouling organisms. Water Chlorination Environmental Impact and Health Effects, Jolley et al. (eds) Ann Arbor Sci. Vol. 3, pp. 599-606.

Travade F. \& Khalanski M., 1986. Contrôle de la salissure biologique des circuits de centrales thermiques côtières par les moules (Mytilus edulis). Étude d'optimisation de la chloration à Gravelines. Haliotis 15, pp. 265-273.

Tsou J., 1996. Non-toxic foul-release coatings to reduce condenser macrofouling. Innovators with EPRI technology. IN-103476, 2 pp.

Turner H.J., Reynolds D.M. \& Redfield A.C., 1948. Chlorine and sodium pentachlorphenate as fouling preventatives in sea water conduits. Ind Eng Chem 40, pp. 450-453.

Tyndall R.L., Ironside K.S., Metler P.L., Tan E.L., Haezn T.C. \& Fliermans C.B., 1989. Effect of thermal addition on the density and distribution of Naegleria fowleri thermophilic amoebae and pathogenic in a newly created cooling lake. Appl. Environ., Microbiol. 55 (3), pp. 722-732.

US EPA, 1992. Framework for ecological risk assessment. EPA/60/R-92/001. Washington DC.

Usami M. \& Ueda K., 1993. Antifouling system for ship hulls by electro-conductive coating. CEbalia, vol. XIX, Supplement, p. 641.

Van Benschoten J.E.. Jensen J.N., Lewis D. \& Brady T.J., 1993. Chemical oxidants for controlling Zebra Mussels (Dreissena polymorpha): a synthesis of recent laboratory and field studies. In: Zebra Mussels Biology, Impacts and Control. Nalepa T.F. \& Schloesser D.W. (eds) Lewis Publishers, London, pp. 599-619.

Van den Brink F.W.B., Van der Velde G., Bij de Vaate A., 1989. A note on the immigration of Corophium curvispinum Sars, 1895 (Crustacea, Amphipoda) into the Netherlands via the River Rhine. Bull. Zool. Mus. Amsterdam 11, pp. 211-213.

Van den Brink F.W.B., Van der Velde G., \& Bij de Vaate A., 1993. Ecological aspects, explosive range extension and impact of a mass invader, Corophium curvispinum Sars, 1895 (Crustacea, Amphipoda), in the Lower Rhine (The Netherlands). Oecologia 93, pp. 224232.

Vanderpoeg H.A., Liebig J.R. \& Gluk A.A., 1995. Development, survival and settling of Dreissena polymorphan the laboratory for different food concentrations, physical conditions and substrates. Fifth International Zebra Mussel and Aquatic Nuisance Organisms. Conference. 21-24 Feb. 1995. Toronto, Ontario, Canada.

Van der Velde G., Paffen B.G.P., Van den Brink F.W.B., Bij de Vaate A., Jenner H.A., 1994. Decline of Zebra Mussel populations in the Rhine. Competition between two mass invaders (Dreissena polymorpha and Corophium curvispinum). Naturwissen 81, pp. 32-34.

Van der Velde G., Rajagopal S. \& Jenner H.A., 1997. Sublethal response of Zebra mussel, Dreissena polymorpha (Pallas) to low-level chlorination: a laboratory study. Conference proceedings Seventh International Zebra Mussel and Aquatic Nuisance Species. Conference. Jan. 28 to 31 1997. NewOrleans (USA), pp. 147-162.

Van Wijk D.J. \& Hutchinson T.H., 1995. The ecotoxicity of chlorate to aquatic organisms, a critical review. Ecotoxicology and Environmental Safety. 32, pp. 244-253. 
Vanmaele R., Leyneen M., Duvivier L., Girboux P., Delanaye J.N. \& Ollivier F., 1998. Ozonization of an Auxiliary Circuit of a Cooling Water System from a Power Station. A Field Study. Proceedings of International Ozone Regional Conference. Poitiers France, 23-25 September 1998, pp. 33-1 - 33-7.

Verschueren K. 1983. Handbook of environmental data on organic chemicals. Second edition. Van Nostrand Reinhold Company, New-York, 1310 pp.

Vervoort W., 1946. Fauna van Nederland aflevering XIV Hydrozoa (C1. A Hydropoliepen AW. Sijthoff Leiden, 336 pp.

Wasel-Nielen J. \& Baresel M., 1997. The treatment of cooling water with ozone at Hoechst AG in comparison with other microbiocidal processes. VGB Kraftwerkstechnik $77, \mathrm{~N}^{0} 2$, pp. 124128.

Watermann B., Berger H.D., Sönnischen H. \& Willemsen P., 1997. Performance and effectiveness of non-stick coatings in seawater. Biofouling. Vol. 11, pp. 1-18.

Waugh G.D., 1964. Observations on the effects of chlorine on the larvae of oysters (Ostrea edulis (L)) and barnacles (Elminius modestus (Darwin)) Ann. appl. Biol. 54, pp. 423-440.

Welch F.J. \& Joy J.E., 1984. Growth rates of the Asiatic clam Corbicula fluminea in the Kanawha River, West Virginia. Freshw. Invertebr. Biol. 3, pp. 139-142.

Wellauer R. \& Kyas A., 1987. Ozone as a biocide for cooling water systems. Proc. 8th Ozone Congress (Zürich, Switzerland, Intl. Ozone Assoc.), pp. G12-G21.

Wellauer R. \& Oldani M., 1990. Cooling water treatment with ozone, Ozone: Sci. Eng., 12(3), pp. 243-253.

White G.C., 1972. Handbook of chlorination for potable water, wastewater, cooling water, industrial Processes and swimming Pools. Van Nostrand Reinhold Company. New York, 744 pp.

White G.C., 1986. The Handbook of Chlorination, Second Edition. Nostrand
Reinhold Company, New York. ISBN 0-442-29285-6, $1069 \mathrm{p}$.

Whitehouse J.W., 1975. Chlorination of cooling water, a review of literature on the effects of chlorine on aquatic organisms. Report No RD/L/M 496, Central Electricity Research Laboratories, Leatherhead, Surrey, $22 \mathrm{pp}$.

Whitehouse J.W., 1990a. Commissioning of the biofouling control rig and the first experiment - July to November 1988 National Power Report No TEC/L/0316/R90.

Whitehouse J.W., 1990b. The growth and control of biofouling deposits on cooling tower plastic packing, results from the biofouling rig. 1988-1990 National Power Report No TEC/I/0317/R90.

Whitehouse J.W. \& Blank L.W., 1985. Cooling tower design and operation and the incidence of algal biofouling results of the 1983 survey CEGB Report No TPRD/L2838/N85 CERL Leatherhead UK, $19 \mathrm{pp}$.

Whitehouse J.W. \& Coughlan J., 1990. Microbiofouling on plastic packing in cooling towers, a case for chlorine treatment? Proceedings 6th Conference on water Chlorination, Environmental Impact and Health Effects. Oak Ridge Tenn., May-3-8 1987, in Jolley et al, 1990, pp. 555-563.

Whitehouse J.W., Coughlan J. \& Bamber R.N., 1987. An assessment of the requirements for chlorination for mussel fouling control at Wylfa power station CEGB Report No TPRD/L/3096/R86.

Whitehouse J.W., Khalanski M., Saroglia M.G. \& Jenner H.A., 1985. The control of biofouling in marine and estuarine power stations. Joint report of CEGB, EDF, ENEL and KEMA, 48 pp.

WHO, 1993a. Environmental Health Criteria 93 - Chlorophenols other than pentacholophenol. The World Health Organisation Geneva.

WHO, 1993b. Guidelines for drinking-water quality. Vol. 1, Recommendations. WHO Geneva. 
Wiancko P.M. \& Claudi R., 1994. The Ontario Hydro final strategy for Zebra mussel control. Fourth international Zebra Mussel Conference, Madison Wisconsin, USA.

Wilde E.W., Soracco R.J., Mayack L.A., Shealy R.I., Broadwell T.L. \& Steffen R.F., 1983. Comparison of chlorine and chlorine dioxide toxicity to fathead minnow and bluegill. Wat. Res. 17, pp. 1327-1331.

Wolff W.J., 1969a. Mercierella enigmatica Fauvel, een borstelworm van het brakke water, voor het eerst in Nederland gevonden. Levende Natuur 72, pp. 85-92.

Wolff W.J., 1969b. The Mollusca of the estuarine region of the rivers Rhine, Meuse and Scheldt in relation to the hydrography of the area. II. The Dreissenidae. Basteria 33, pp. 94-103.

Woods Hole Oceanographic Institution, 1952. Marine fouling and its prevention. US Naval Institute, Annapolis, 388, pp.
Wright D.A., Kennedy V.S., Roosenburg W.H., Castagna M. \& Mihursky J.A., 1983. Temperature tolerance of embryos and larvae of five bivalve species under simulated power plant entrainment conditions, a synthesis. Mar. Biol. 77, pp. 271-278.

Yamazaki M., 1965. Problems in using sea water for condenser cooling in thermal power stations. In Proc Second Int Conf, Advances in Wat Poll Res. Vol. 3 (Pearson E.A. Ed.), Pergamon Press Oxford England, pp. 117-132.

Yokouchi H., Nonaka T. \& Kawabe A., 1996. Comparative tests on non-toxic antifouling pipe treatment techniques using model canals. Proceedings of 1996 Condenser Technology Conference, EPRI TR-106781 2504, p. 17-14.

Zibrowius H. \& Bellan G., 1969. Sur un nouveau cas de salissures biologiques favorisé par le chlore. Tethys 1, pp. 375382. 


\section{Annex 1}

\section{Heat treatment}

In the Netherlands, the Eems power station, has been equipped with a recirculation system adapted for heat treatment. The plant (600 MWe) is located on the Eems-Dollard estuary and experiences serious mussel fouling. Heat treatment is being practised at the station on a trial basis (Jenner, 1982).

A schematic diagram is presented of the cooling system of the Eems powert station (fig. 1). Normal operation is shown on the left side of the figure. The right side represents the situation during recirculation (heat treatment) of the A-culvert. Cooling water which has passed the condensers $\mathrm{A}$ and $\mathrm{B}$ is partly (about $50 \%, 4-5 \mathrm{~m}^{3} \mathrm{~s}^{-1}$ ) carried back via culvert $A$ to the inlet of pump B. The recirculated water flows again through the condenser to pick up additional heat. In this way the cooling water temperature can be raised. Heat treatment of the B-culvert can be done similarly. The power station remains operational during heat treatment, but power production has to be reduced somwehat. The design of the circuits used by SCEC in order to treat the intake and discharge culverts is shown in fig. 2 .

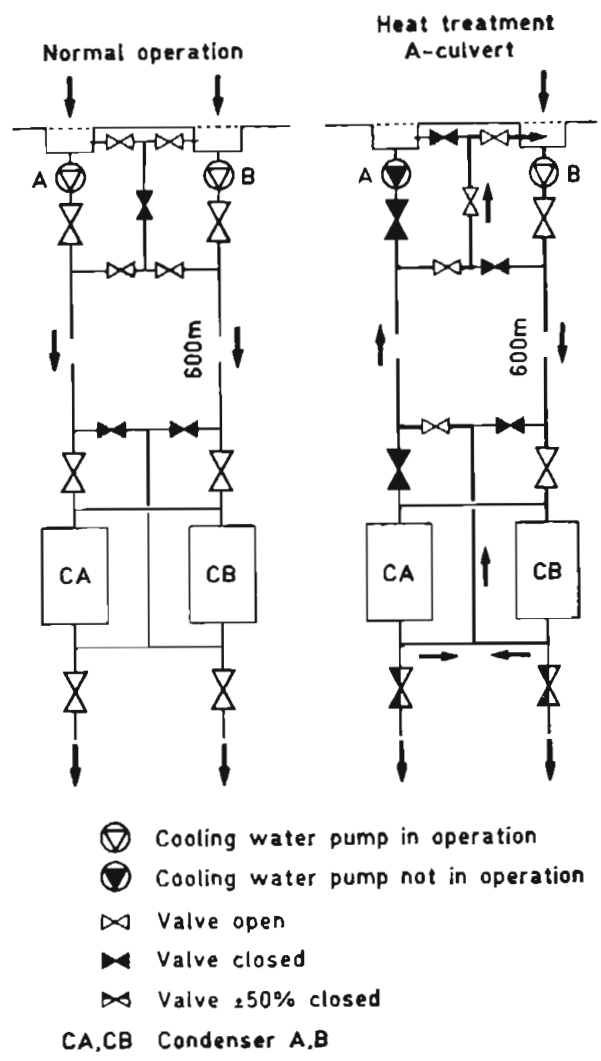

Fig. 1. - Schematic diagram opf the cooling water flow at normal operation and during heat treatment of the Eems power station. 


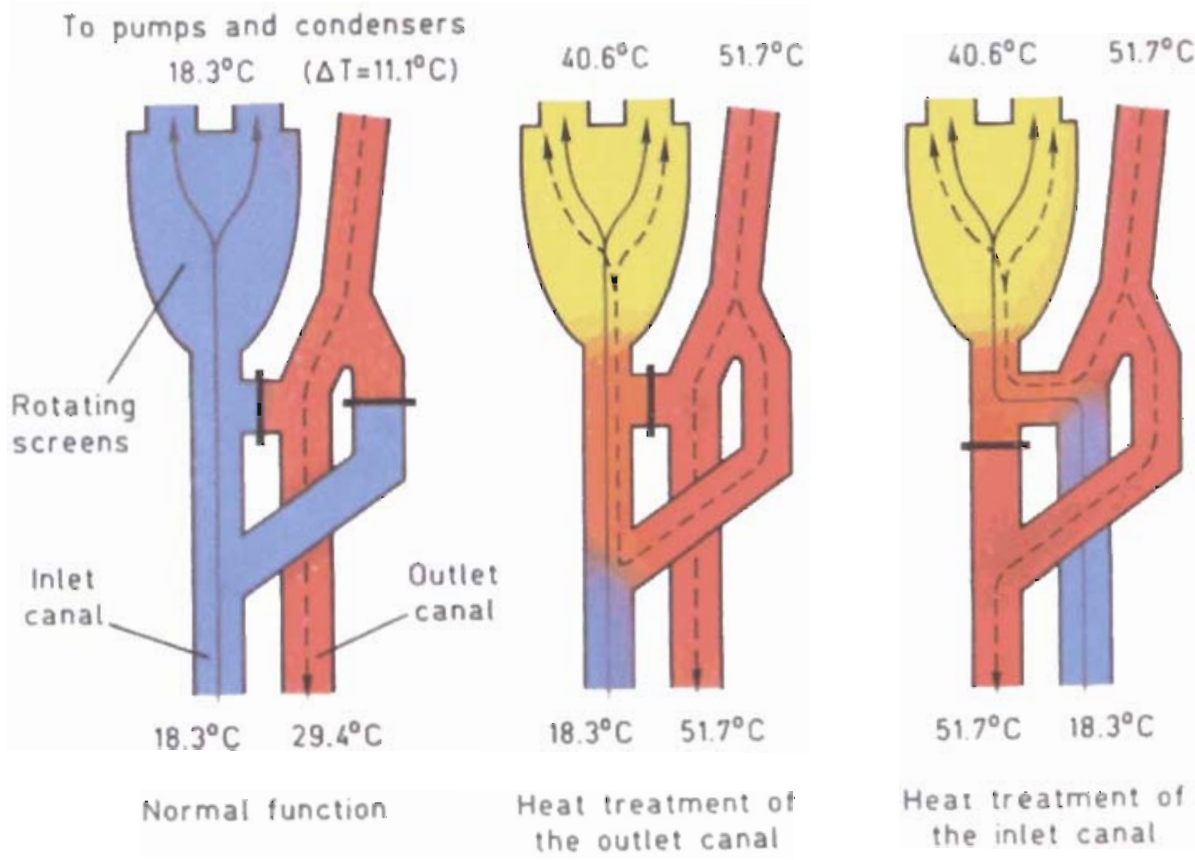

Fig. 2. - Diagram of heat treatment of the inlet and discharge canals used by SCEC (Graham ef al. 1977) 


\section{Annex 2}

\section{Legislation and Policy in North America and selected European Union Member States relating to the use of Biocides}

In Europe, subsidiarity dictates that EU Directives are implemented through national regulations. However, local issues remain influencial, and local initiatives in regulatory practice can be disseminated elsewhere. This annex summarises what is known of the local regulatory situation in North America and across Europe.

Current concerns over the use of chlorine as a biocide can be traced, in past, to the Great lakes Area of North America. This area of the USA and Canada is highly industrialised and has a high population density. Chemical pollution of the Great Lakes has been of concern to various Government Agencies for over two decades and this has resulted in extensive research programmes examining the possible effect of chemical contaminants on the health of residents. These have particularly focused on chlorinated hydrocarbons such as PCBs and organochlorine pesticides (e.g. DDT and Lindane). These were of particular concern because of their persistence, toxicity, carcinogeni- city and a tendency towards bioaccumulation. These findings prompted programmes across the western world to eliminate their use where possible. More recently, research in Europe and in the USA has raised concerns that a number of industrial chemicals including chlorinated hydrocarbons may mimic natural oestrogens or anti-androgens and could potentially affect the reproductive success of animals or man.

This research is still on-going and is likely to continue to raise the public profile of chlorinated hydrocarbons and the release of chlorine to the environment in general.

\section{NORTH AMERICA}

\subsection{USA}

The United States Environmental Protection Agency (USEPA) has a pesticide programme which authorises all active ingredients for pestici- 
des/biocides on a national basis. The Federal Insecticide, Fungicide, Rodenticide Act (FIFRA) requires that the ecosystem as well as humans, be protected from unreasonable risks associated with the production, distribution, storage and use of pesticides. Ecological risk assessments are undertaken to determine this for biocides. For example, DBNPA, a non-oxidising biocide, is registered under FIFRA for use in cooling waters and an ecological risk assessment of its use in once-through cooling systems is provided by Klaine et al. (1996). A tiered approach is adopted for ecological risk assessment, with those substances representing insignificant exposure to the environment being screened out at tier one to avoid the more detailed assessment required at tier two (USEPA 1992, SETAC 1994). All active ingredients, including chlorine, are currently being reassessed by the Pesticide Safety Division of the USEPA.

Whilst the use of chlorine as a biocide is controlled by FIFRA there has been a tendency to undertake less onerous risk assessments on its use in cooling waters. This is because, unlike most other pesticides/biocides, its primary release pathway to the environment is via point source discharges to the aquatic environment. These effluent discharges are controlled either by State Regulatory Authorities or, in a limited number of cases, the regional offices of the EPA. Thus unlike the highly centralised approach to the control of most agricultural pesti- cides/biocides in the USA, under the Pesticides programme, the control of the use of biocides in cooling waters is very much a site specific issue. It would appear that in general the use of chlorine as a biocide for cooling waters does not appear to be of great concern in the USA, although there may be local instances where a higher priority is assigned to its control.

The USEPA has conducted a broader study into the use and release of biocides, including chlorine, into the environment. A draft report on this was produced earlier in 1996 but is not publicly available and this initiative appears to have stalled at present, possibly because of budgetary constraints (Inglow, pers. com. USEPA)

\subsection{Canada}

There is no national control on the use of biocides in cooling waters in Canada except where they are sold as pesticide control products, in which case they require registration.

The use of oxidising biocides in cooling waters is controlled at Provincial level through the use of permits. Environment Canada has produced environmental codes of practice for steam generation which are used as guidelines to support these permit granting activities. The majority of power generating systems are oncethrough systems using chlorine as a cooling water biocide. The Canadian Water Quality Guidelines (CCREM 1987) may also be used in framing permits and these suggest that for the 
protection of freshwater aquatic life the concentration of Total Available Chlorine (as measured by the amperometric method) should not exceed $2 \mathrm{mg} / \mathrm{L}$.

The environmental Codes of Practice for Steam Electric Power Generation (EPSI/PG/1 1985) have no legal status and were developed with a federal-provincial-industry task force. The codes encompass the siting, design, construction, operation and decommissioning phases of steam electric power projects, which includes all facilities which use a steam cycle to produce electrical energy (i.e. both fossil-fuelled [coal, oil and gas] and nuclear [CANDU] power station). The codes deal with multimedia considerations although the design phase primarily addresses water-related concerns.

The following recommendation relates to biofouling control in oncethrough condenser cooling systems (Recommendation R111) :

1. chemicals should only be used when demonstrated as necessary;

2. when chlorine use has been demonstrated as necessary, then :

- Only the minimum amount necessary should be used;

- The maximum concentration of total residual chlorine at the outlet of the condenser undergoing chlorination should not exceed $0.5 \mathrm{mg} / \mathrm{L}$;

- Chlorine should be applied intermittently and the injection point should be immediately upstream of the condensers and sets of auxiliary coolers, unless continuous chlorina- tion or a different injection point has been demonstrated to be necessary to control biofouling; at no time, however, should chlorine be introduced upstream of the travelling screens;

- Chlorine application should be limited to no more than one condenser and set of auxiliary coolers at a time, and should occur in daylight hours.

The rationale presented for this is that chlorine is almost certain to cause mortality or sublethal effects to entrained organisms and has the potential for producing carcinogenic compounds in receiving waters subsequently used for drinking. The recommendation either eliminates or reduces the amount of chlorine used and injection in the most sensitive area is prohibited (i.e. the forebay). Because injection close to the condenser or heat exchangers will minimise the residual chlorine loss prior to contact with the most important biofouling organisms, less chlorine will be required.

The recommendation also identifies a number of opportunities to minimise biofouling control:

- The use of mechanical cleaning devices to clean condenser tubes during operation or shutdown, and

- The chemical or mechanical cleaning of condensers on heat exchangers during shutdown (with chemical wastes being collected and pre-treated before discharge).

Where the most common biocide, chlorine, is used, the recommendation goes on to say that: 
- Its use can be minimised by an injection and control system designed so that injection is immediately upstream of the condenser with control being maintained by measuring total residual chlorine at each condenser outlet;

- A dechlorination system can be provided (e.g. sulphur dioxide or sodium sulphite injection) if, for process reasons, the individual condenser discharges have to exceed $0.5 \mathrm{mg} / \mathrm{L}$ TRC.

- Residual chlorine will be more readily chemically reduced in the receiving environment in the presence of ultra-violet light during the day.

Whilst the recommendation notes that intermittent chlorination is generally adequate for freshwater biofouling control it also states that continuous chlorination might be necessary for the control of mussels and barnacles in sea water.

Recommendations pertaining to the use of biocides, other than chlorine, were deferred.

Recommendation R 112 addresses the control of corrosion, scaling or silting in once-through or partially open cooling systems, and recommends the following:

- On-line application of chemicals should not be used unless they are demonstrated to be necessary and demonstrated not to cause environmental damage;

- If the use of on-line chemicals is demonstrated to be necessary but it cannot be demonstrated that such chemicals will not cause environmen- tal damage, the dose rates and method of application should be such that only the minimum amount of chemical is used;

- Spent cleaning solutions generated from off-line chemical cleaning of condensers should be contained and treated before discharge.

Recommendation R 201 addresses contaminants arising from evaporative recirculating cooling systems for the purposes of controlling biofouling, corrosion and/or scaling in evaporative recirculating systems. It suggests that :

- Chemicals should not be used unless demonstrated to be necessary or to be environmentally innocuous;

- Asbestos based materials should not be used for cooling tower components;

- Chromium chemical additives should not be used for cooling pond recirculating systems;

- Chemical additive systems (if required) should be designed to minimise the use of chemicals while providing adequate biofouling, silting, corrosion, and/or scaling control.

The rationale behind this is stated as 'this recommendation eliminates, or at least discourages, the contamination of receiving waters with deleterious substances in blowdown from evaporative cooling systems, which are the largest wastewater volume in stations that use such systems. Asbestos-based materials used in cooling waters may become airborne (by drift) and may be carcinogenic if inhaled. Hexavalent chromium is highly 
toxic and may form difficult to manage waste precipitate (sludge) in cooling ponds. Chlorine may form toxic and carcinogenic compounds, and other biofouling, silting, scaling and corrosion chemicals may be detrimental. Their use is discouraged but, if necessary for process reasons, their minimum usage is encouraged to minimise discharges.

\section{EU Member States}

\subsection{The Netherlands}

The Netherlands has a central Government with a large degree of functional decentralisation. The Ministry of Transport, Public Works and Water Management is responsible for the management of state waters (North \& Wadden Seas, IJsselmeer, the major rivers, estuaries and deltas), including discharges to them, its executive body, the Rijkswaterstaat, is helped by its Regional Directorates in the 12 Provinces and the Institute for Inland Water Management and Wastewater Treatment (RIZA) which advises on policy and technical matters.

Non-state waters (minor rivers, lakes and canais) are administered by the Provinces. However, all but three have delegated their responsibilities in this area to Water Boards. Power Stations, however, are likely to be sited on State Waters and thus discharges from them will tend to be controlled by the Rijkswaterstaat.
The approach adopted by the Rijkswaterstaat and RIZA to consenting cooling water discharges varies according to whether the system is once through, the main type of system operated in the country, or a recirculation system. In both cases the potential environmental impact on the relevant receiving waters will be assessed and the discharge permit will reflect this. The most commonly used oxidising biocide is chlorine, although RIZA generally tries to minimise its use. Where use is permitted, the regulator will generally stipulate a limit of $0.2-0.3 \mathrm{mg} / \mathrm{L}$ free chlorine at the end of the system (roughly equivalent to a dose of $2-3 \mathrm{mg} / \mathrm{L}$ ).

The Netherlands has imposed abatement measurements on certain discharges for specific groups of organohalogens which has resulted in an $88 \%$ reduction of $\mathrm{AOX}$ discharged to the aquatic environment over the last 15 years (PARCOM, 1995). Thus proportionally, the contribution of cooling water discharges to total AOX releases in the country is likely to be increasing. Further research is likely to be focussed on the oestrogenic potency of discharges and emissions from industry and reduction measures will be targeted on the largest discharges and emissions of AOX. The main sources in the Netherlands determined in 1990 included hypochlorite use in households, but did not include discharges from power stations. AOX may be used as a control parameter for industries such as the paper and pulp sector, but is not seen as applicable to more complex effluents. 


\subsection{Germany}

Pollution control in Germany is the responsibility of the Lander (the 16 constituent States of the country). Therefore any national (Federal) pollution control legislation requires the collective agreement of the Lander and implementation of the legislation into the Laws of the individual Land.

The main law protecting the aquatic environment is the Federal Water Resources Act (Wasserhaushaltgesetz) last amended 1990. Article 7A of the Act requires that effluents containing dangerous substances must be treated by Best Available Technology (BAT) irrespective of whether they are discharged directly to surface water or to sewers. The Waste Water Origins Regulation (Verordnung uber die Herkunftsbereiche von Abwasser, last amended 1991), defines those industrial branches which may contain dangerous substances in their effluents.

The standards to be achieved by applying BAT are laid down in Annexes to the Federal General Administrative Regulation which are applicable as a minimum throughout the country. More stringent standards may be laid down by the regulatory authorities on a site specific basis, if this is required to protect the receiving water. The need for more stringent standards than those based on BAT requires detailed justification as most of the Lander have not laid down Quality Objectives or Standards for the protection of the receiving waters. One exception is Nordrhin-Westphalia which has stipulated minimum requirements for running waters for a number of parameters, which may be used as a guide to identify where more stringent controls need to be applied.

Cooling water has been defined as one of the 'effluents' potentially containing dangerous substances and which therefore requires the application of BAT. Minimum standards to be achieved before cooling water can be discharged are contained in annex 31 (water treatment, cooling systems, steam production) last amended 31 January 1994.

Continuous dosing of disinfectants (e.g. chlorine, chlorine dioxide) is generally not permitted. However, the regulation does allow shock dosing. In principle, provided dosing is discontinued during a short period every day this is classified as shock, rather than continuous. The regulators have indicated that this is seen as a loophole and will need to be dealt with in the future.

For each cooling water discharge produced, depending on the operation of the cooling system, some general requirements apply with more specific limit values being laid down.

The main control parameters for cooling water are the concentration of the residual oxidant (as chlorine), AOX (which can be considered as surrogate parameter for organic chlorinated and brominated substances formed when using chlorine, chlorine dioxide or bromine as disinfectants), and a luminescent bacteria test (a surrogate for acute toxicity). 
The general requirements are :

a) With the exception of phosphates and polycarboxylates, all other organic complexing agents used must be easily biodegradable as defined in the German Chemical Act.

b) Chromium, mercury, nitrite and organometallic compounds and mercaptobenzthiozol may not be present in cooling water discharges.

The following specific minimum requirements apply, depending on the operation of the cooling system.

\subsubsection{Requirement for cooling water in once through operation-shock dosing}

\begin{tabular}{l|c|} 
& $\begin{array}{c}\text { Qualified spot } \\
\text { si) }\end{array}$ \\
\hline $\begin{array}{l}\text { Chlorine dioxide, chlo- } \\
\text { rine(as free chlorine) }\end{array}$ & $0.2 \mathrm{mg} / \mathrm{L}$ \\
AOX & $0.15 \mathrm{mg} / \mathrm{L}$
\end{tabular}

(1) qualified spot sample requires that 5 individual samples are taken within 2 hours, which are mixed before analysis

(?) other biocides with the exception of ozone and $\mathrm{H}_{2} \mathrm{O}_{2}$ should not be present

\subsubsection{Requirement for cooling} water bleed effluent from main recycle power station cooling water

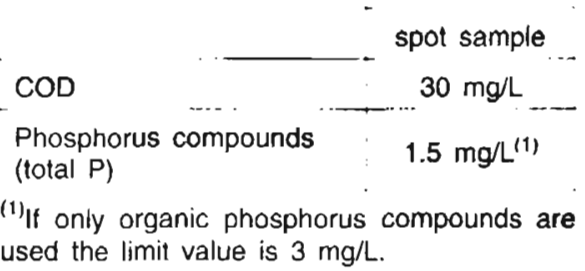

If shock dosing with a biocide is practised the following conditions apply :

\begin{tabular}{|c|c|}
\hline & spot sample \\
\hline AOX & $0.15 \mathrm{mg} / \mathrm{L}$ \\
\hline $\begin{array}{l}\text { Chlorine dioxide, chlorine, } \\
\text { bromine(as chlorine) }\end{array}$ & $0.3 \mathrm{mg} / \mathrm{L}$ \\
\hline $\begin{array}{l}\text { Inhibition of biolumines- } \\
\text { cence (bacteria) }\end{array}$ & $\begin{array}{c}\text { GL12 } \\
\text { (see note) }\end{array}$ \\
\hline
\end{tabular}

The limit value for bioluminescence is also achieved if it can be shown from manufacturing information that the biocide has degraded sufficiently to a value below GL12 (GL12=dilution to non-toxic effect $=1$ unit wastewater and 11 units dilution water) before the effluent bleed is released. Discussions are still going on in Germany how this can best be implemented (e.g. What data are required from the manufacturers). In addition the biocides should not contain any zinc compounds.

A PARCOM working Party has suggested that for cooling waters the biotest requirements are $T^{-} L=4$ (i.e. $G L$ $=4$ ). This value does not, however, agree with the current legislative requirement.

\subsubsection{Requirement for other cooling water bleed effluent}

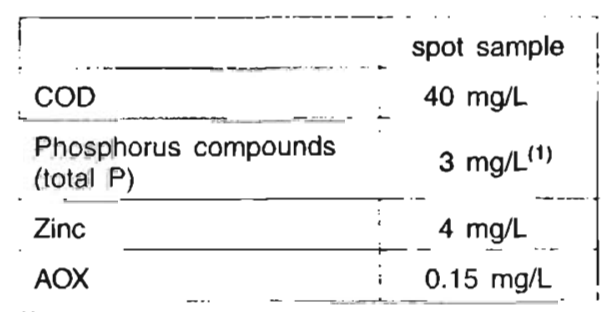

(1) The limit is increased to $4 \mathrm{mg} / \mathrm{L}$ if no zinc compounds are used and to $5 \mathrm{mg} / \mathrm{L}$ if no zinc compounds and only inorganic phosphorus compounds are applied. 
If shock dosing with a biocide is practised the following conditions apply:

spot sample

After shock dosing with

chlorine, chlorine dioxide.

bromine (as chlorine)

AOX

Inhibition of bioluminescence :

In addition to these limits on the quality of the effluent they can discharge, dischargers have a powerful incentive for minimising their emission of biocides and associated by-products in the Federal Waste Water Charges Act. The charges levied on a discharger are based upon, amongst other things, AOX and acute effluent toxicity.

The standards outlined above are used as minimum requirements throughout the country but certain Land have derived stricter standards. The minimum quality requirements for running waters in Nordrhin-Westphalia give a value for AOX of $40 \mu \mathrm{g} / \mathrm{L}$. Thus depending on the dilution available in the receiving waters, stricter standards than those given in Annex 31 of the Federal General Administrative Regulation may need to be met by the discharger.

\subsection{France}

\section{Regulatory Framework:}

France takes a dual approach to the protection of the aquatic environment based both on Integrated Pollu- tion Control and the use of quality (EQOs) for the receiving waters.

\subsubsection{Receiving Waters}

French EQOs are almost entirely based on European Union Directives and lor WHO Guidelines (Pers. comm., $F$ Bordet, EDF). The main French legislation relating to the quality of receiving waters are:

a) June 1975 (75/460/EEC), concerning the quality required of surface water intended for the abstraction for drinking water.

b) July 1978 (78.659/EEC), concerning the quality of fresh waters needing protection or improvement in order to support fish life.

c) October 1979 (79/923/EEC) on the quality required for shellfish waters.

These Directives have been incorporated into French law in two separate regulations:

- décret du 3 janvier 1989, relatif aux eaux destinées à la consommation a l'exclusion des eaux minerales naturelles (decree concerning water intended for human consumption, excluding natural mineral waters).

- décret du 19 dĖcembre 1991, relatif aux objectifs de qualité assignĖs aux cours d'eau, sections de cours d'eau, canaux, lac ou étangs et aux eaux de mer dans les limites territorials (decree concerning quality objectives for water courses, sections of water courses, canals, lakes or ponds and coastal waters within territorial limits). 
The decree of 3 January 1989 (issued by circular dated 16 May 1989) imposes maximum values, for specific halogenated chemicals in water to be used for abstraction for drinking water supply. Those that have implications for the discharge of cooling waters containing biocides and their by-products are summarised below:

- carbon tetrachloride (tetrachloromethane) $<3 \mu \mathrm{g} / \mathrm{L}$

- 1,2-dichloroethane $<10 \mu \mathrm{g} / \mathrm{L}$

- trichloroethylene (trichloroethane) $<30 \mu \mathrm{g} / \mathrm{L}$

- chloroform (trichloromethane) $<30$ $\mu g / L$

The decree of 19 December 1991 , requires that the concentration of each organohalogen substance (either in the surrounding water or in the tissue of the shellfish) must not exceed that which would provoke harmful effects on shellfish. No specific chemicals or limit values are provided. However, in an annex to this decree concerning the quality of surface waters needing protection or improvement in order to support fish life, a limit of $5 \mu \mathrm{g} / \mathrm{L}$ total residual chlorine $(\mathrm{HOCl})$ is specified.

\subsubsection{Effluents}

There are also regulations on 'Installations Classées pour la Protection de l'Environnement (ICPE)' (classified installations) (Loi du 19 Juillet 1976, arrêté du 2 février 1998), which apply to the most polluting activities in France (with the exception of the nuclear industry, which is covered by separate legislation). This system sets
BAT based limits for point source discharges, including those of cooling waters The conditions for power stations are summarised below.

The ICPE Regulations provide powers to set discharge consents for conventional power stations (coal and fuel oil) and, in particular, the order (arrêté) of 2 February 1998 specified a limit of $1 \mathrm{mg} / \mathrm{L}$ AOX (adsorbable organohalogens) or EOX (extractible organohalogens) where the discharge is greater than $30 \mathrm{~g}$ per day. The regulatory authorities acknowledge that this limit is probably more applicable to small industries and that in practice more stringent standards would be set for cooling water discharges from power stations. Before standards are set for cooling water discharges, the discharger would be expected to undertake toxicity testing and provide the regulator with the results.

The regulators approach to the control of the discharge is also dependent on the type of cooling system used. Two broad categories can be distinguished; power stations situated on coastal sites equipped with opencircuit once-through direct cooling and those inland, on rivers, using opencircuit recirculating tower assisted cooling.

\section{(i) Coastal discharges}

The conditions which are normally applied to installations on the English Channel or North Sea, allow continuous chlorination with an initial concentration of $1 \mathrm{mg} / \mathrm{L}(\mathrm{HOCl})$ at a water temperature of $10^{\circ} \mathrm{C}$. No other condi- 
tions are normally imposed on cooling water discharges of this type.

Conditions applying to two specific coastal power stations are:

- Flamanville: a requirement to reduce the level of chlorination to 0.5 $\mathrm{mg} / \mathrm{L}$ within a 6 year period,

- Le Havre: the total concentration of free chlorine and chloramines in the discharge must be less than 0.1 $\mathrm{mg} / \mathrm{L}$.

\section{(ii) River discharges}

Conditions for chlorination normally specify intermittent treatment (once or twice per year) with a free chlorine residual in the discharge not exceeding $0.1 \mathrm{mg} / \mathrm{L}$. For some sites, the Water Police can request that monitoring is carried out for trihalomethanes (chloroform).

As with Germany, French dischargers have an additional motivation to reduce the amounts of biocide and associated by-products that they discharge. This is from the pollution charge levied on the discharger by the Agences de l'Eau (public authorities responsible for water resource management).

The Agences use AOX as one of the parameters on which the discharge levy is based. The charge is calculated on the basis of the maximum quantity of 'pollution' discharged per day and, for AOX, this can vary from $0 \mathrm{FF}$ per $\mathrm{kg}$ to $3000 \mathrm{FF}$ per $\mathrm{kg}$ depending on the policy of the individual Agence de l'Eau involved. Since 1998, the Agence de l'Eau Seine-Normandie uses the bromoform concentration, instead of AOX, as the tax parameter for cooling waters released by the nuclear power stations located on the English Channel coast.

Any future tightening of standards in France relating to the use of biocides by the power industry are likely to be stimulated by new European Directives, in particular, those relating to the Ecology of Natural Waters, the Drinking Water Directive and the Biocides Directive.

\subsection{Belgium}

Belgium has no legislation relating specifically to power stations (pers comm MM Deweeyn and Malangreau, Electrabel). However, industrial discharges, including cooling waters, usually require a permit. The electricity generator, Electrabel, states that a discharge consent applies for cooling water, which specifies a limit for free chlorine of $1 \mathrm{mg} / \mathrm{L}$ at the discharge point for both fresh and brackish water. In addition, there are regulations on 'Etablissements Classes' (classified installations) which apply to the most polluting activities in Belgium which control the discharge of effluent via a permit system. Electricity generators do not at present appear to be classified under these regulations.

There is no move to use toxicity based consents in Belgium. An environmental tax system has been discussed by the regulators, however, such a system has not yet been implemented. 


\subsection{Sweden}

The Swedish regulators have taken a series of measures to reduce the risk resulting from chlorine compounds e.g. reducing the exposure to man and the environment by limitations on marketing, discharge/emission restrictions and changes in the way chemicals are handled in the working environment (PARCOM, 1995).

An important area for risk reduction is seen to be the use of bleaches by the pulp and paper industry. The Swedish Chlorine Plan has been developed with the aims of increasing the actions taken against the use of chlorine compounds in Sweden and other countries. It recommends that the use of chlorine for disinfection should cease and also highlights the use of hypochlorite in cooling systems. The use of un-chlorinated disinfectants in addition to chlorinated disinfectants is recommended for use in swimming pools where the complete elimination of chlorine use would be difficult.

\subsection{Denmark}

Denmark has initiated a project to develop a model to estimate the industrial use of chlorine and organochlorine compounds. It will include net import, production and industrial use as well as an assessment of the final fate of selected hazardous compounds (PARCOM, 1995).
The use of chlorine in cooling water systems is not prohibited by law. However, in the Environmantal Act, there is a clear intention to reduce the discharge of dangerous substances, including chlorine, and there is given a list of types of factories, including power stations, requiring authorisation from the local environmental authorities. This environmental authorisation is negociated with the local authority every eight years, and under special circumstances, every four years. All power station units built the last 10 to 15 years are not allowed by local environmental authorities to use chlorine. Consequently, in Denmark, the use of chlorine in cooling water is not prohibited by law but, by regulation, it is made impossible to use.

\subsection{Italy}

The recently introduced Galli Law states that each region of the country has the right to set its own discharge limits. No Region has yet developed such standards and it has been recommended that in the interim the discharge limits stated in the old Merli Law of 1976 be used as guidelines.

The Merli discharge limits include free chlorine $(0.2 \mathrm{mg} / \mathrm{L})$, chloride (1200 mg/L) and chlorinated pesticides $(0.05 \mathrm{mg} / \mathrm{L})$ as parameters. The limits are stated as the maximum concentration which should be present in a single instantaneous sample, or a mean of samples taken within a time period specified by the regional body. Before 1979, the time period had to 
be a minimum of 3 hours, but since 1979 it is left to the regional bodies to determine the time period. Italy is incorporating the standards specified in EC Directives e.g. Drinking Water and Dangerous Substances Directives, into Italian legislation by the adoption of decree laws.

\subsection{Spain}

When Spain entered as a member of the $\mathrm{EC}$, it was necessary to incorporate community decrees to Spanish Legal Ordinance with regard to contamination on account of dangerous substances discharged to seawater. Thus, the general norms published in 74/464/EEC and 86/280/EEC have been incorporated into the Spanish Legal Ordinanace by means of Decree Real 258/1989, which establishes the General Regulation of dangerous substances discharged to seawater which proclaimes that emissions norms, quality points, reference measurement method and control procediments will have to dictate with regard to those substances included in black list substances or grey list substances. Subsequently, modifications have been produced in accordance with EC marks. These modifications are published in B.O.E. (State Official Bulletin) : BOE 241 of 89-11-11; BOE 116 of 91-05-15; BOE 267 of $92-11-06$.

\subsection{United Kingdom}

The UK has implemented all the EU water related legislation and has in addition implemented its own legislation to provide the basis for a comprehensive policy on the protection of the aquatic environment. This legislation assigns roles and responsibilities, but leaves the regulatory authorities to adopt their own approach for protecting the aquatic environment.

In addition, with the introduction of Integrated Pollution Control (IPC) in the UK a new emphasis has been placed on the control of discharges of the most dangerous substances (Red List) by the use of best available techniques (BAT).

\subsubsection{Control of Pollution Act 1974 and Water Resources Act 1991}

These two acts gave the UK environment agencies powers to protect the aquatic environment, including the power to consent and monitor effluent discharges. For most discharges the Scottish Environmental Protection Agency and the (English and Wales) Environmental Agency set site specific conditions, e.g. an EQS for Chlorine has been proposed (NRA 1994) and EQSs for Bromine and Chlorine Dioxide are in preparation. These will be applied to cooling water discharges as well as to other industrial discharges.

The Chlorine EQSs proposed for freshwater are $5 \mathrm{mg} / \mathrm{L}$ TAC as a maxi- 
mum allowable concentration (MAC) and $2 \mathrm{mg} / \mathrm{L}$ TAC (Total Available Chlorine - free and combined chlorine) as an annual average (AA) in the receiving water, whilst the EQS proposed for the protection of solely marine environment is a MAC of $10 \mathrm{mg} / \mathrm{L}$ TRO (Total Residual Oxidant - free and combined chlorine and bromine).

The UK Government has also instigated setting legally binding (statutory) EQSs for the protection of certain uses of the aquatic environment for general physical and chemical parameters (e.g. BOD, COD, ammonia etc.) rather than dangerous substances. The first set of regulations - The Surface Waters (River Ecosystem) (Classification) Regulations 1994 (SI 1057) - define five classes of water in terms of their ability to support aquatic life. The classes are based on EQSs for nine parameters. These parameters do not include residual chlorine.

\subsubsection{The Environmental Protection Act 1990}

Part 1 of the Environmental Protection Act 1990 introduced a system of integrated pollution control (IPC) in the UK as a framework for controlling releases from certain prescribed in- dustrial processes and ensuring compliance with relevant EC Directives on pollution control.

Power Generation using fossil fuels comes under IPC (Chief Inspectors Guidance note for Combustion Processes S2 1.01, HMSO, November 1995) and, as such, is subject to authorisation by HMIP. Nuclear Power Stations themselves do not come under IPC but are still subject to discharge consents issued by the environment agencies for their cooling water releases.

\subsubsection{The Environment Act 1995}

This act gave a responsability to the UK environment agencies "to protect and enhance environment as a whole, so as to contribute to sustainable development ".

\subsubsection{The Planning (Hazardous Substances) Regulations 1992.}

The use of chlorine and bromine is also covered by legislation relating to the storage of dangerous substances above threshold amounts. Sites storing greater than 1 tonne of bromine and/or 10 tonnes of chlorine are required to obtain a storage consent. 


\section{Annex 3}

\section{List of European power stations quoted in the text}

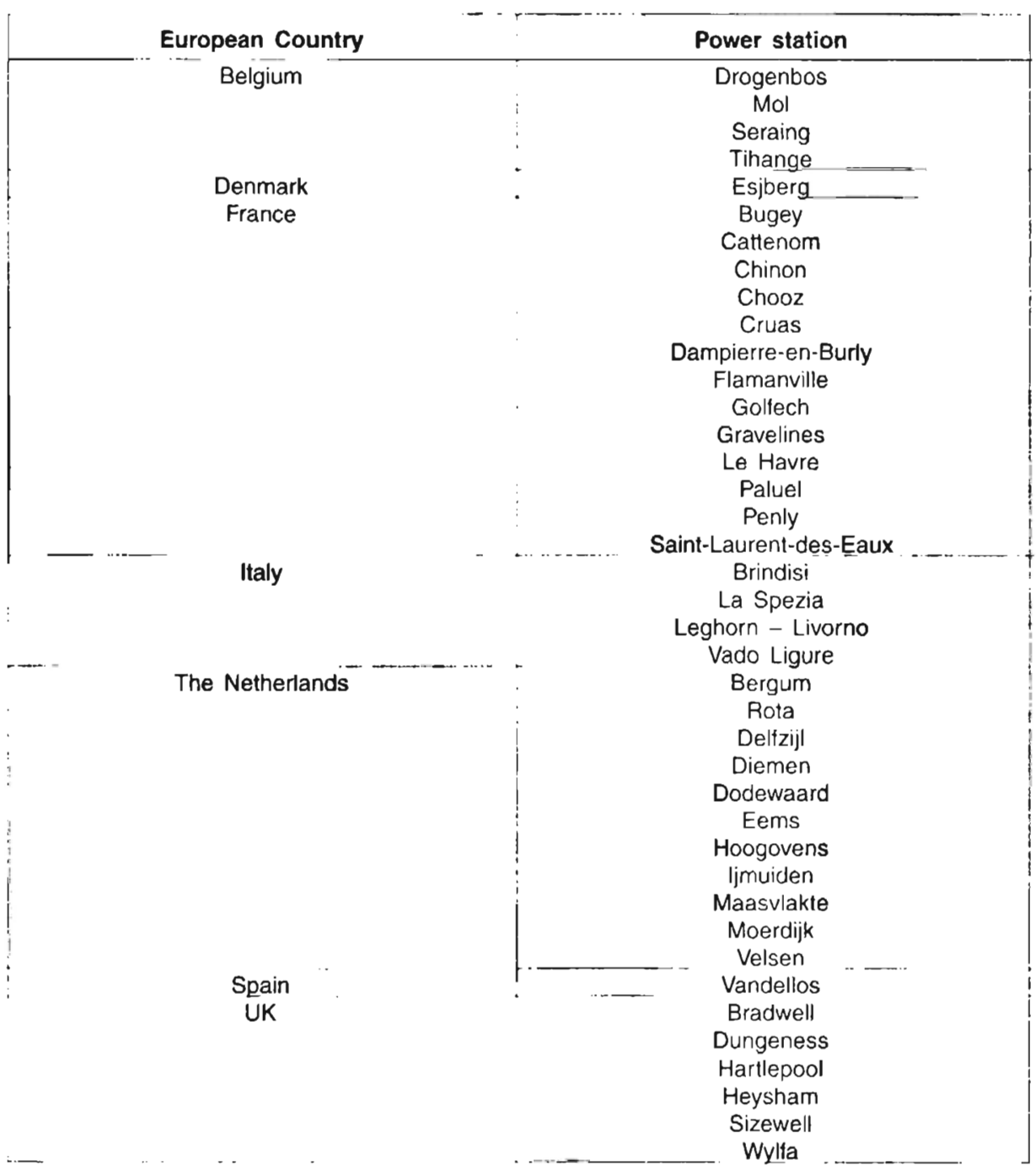




\section{Alphabetical Index on Key Words}

A Acoustic energy, 159-160

Adsorbable Organohalogens (AOX), $92,95,118,121,126,128,133,135$, $138,152-153,181,211-216$

Aluminium anode, 152-153

Anodonta, 50-51, 75

Anti-fouling methods (review), 64-70

Artemia salina, 143

Ascidians, 77

Ascidiella aspersa, 77

Asiatic clam, 19, 40, 75, 105, 142, 162

B Balanus amphitrite, 28

Balanus crenatus, $28-29$

Balanus eburneus, 109

Balanus improvisus, 28, 33-34, 111

Balanus perforatus, 29

Balanus tintinnabulum, 29

Band screen, 4-5

Barbus barbus, 122

Barnacles, 28-30

Benzothiazoles, 147-149

Biocide Authorisation Directive, 173175

Biofilm, 58-59, 102, 106, 163-167

Biological control, 160-161

Biological monitoring, 161-164

Bithynia, 54-55, 75, 114

Brachidontes striatulus, 106-107

Brachydanio rerio, 136

Break point, 93, 95-97

Bromamines, 90, 91, 96, 97

Bromate, 95, 123, 175

Bromoform, 97, 100, 118-119, 124-

127, 178

Bromophenols, 99, 100

Bryozoans, 50, 52-54, 75-76, 126

C Carassius auratus, 120

Carcinus sp., 28

Cathodic protection, 158-159
Chironomus plumosus, 119

Chloramines, 126-127, 178

Chlorate, 129, 135-137

Chlorella, 120

Chlorination Environmental Assessment, 117-126

Chlorination at industrial sites, 111-117

Chlorine chemistry, 90-100

Chlorine continuous monitoring, 101

Chlorine dioxide chemistry , 128-129

Chlorine dioxide efficacy on biofouling, 129-133

Chlorine dioxide Environmental Assessment, 135-138

Chlorine dioxide at industrial sites, 133-135

Chlorine dioxide production, 127

Chlorine efficacy on biofouling, 102-

111

Chlorine storage, production, $89-90$

Chlorite, 123, 127, 129, 135, 136

Chloroform, 118, 127, 172, 178, 215

Chthamalus, 28, 156

Chroococcus, 56

Cladophora glomerata, 58

Clarias gariepinus, 143

Cleaning, 73-74

Closed cooling systems, 7-11

COMAH proposed Directive, 176

Congeria conchleata, 32

Continuous chlorination, 113-116

Cooling water requirements, 7

Copper , 152-153

Corbicula fluminalis, 19, 42, 44

Corbicula fluminea, 19, 40-47, 50, 105, 154-155, 162

Cordylophora caspia, 35, 161

Corophium curvispinum, 47-48, 160 . 162

Crassostrea gigas, 30, 154

Crassotrea virginica, 119 
Cyanobacteria, 54, 55-58, 112

Cyprinus carpio, 119, 143

Cypris larvae, 29-30, 156

D Dangerous Substances Directive, 171172

Daphnia magna, 136

Debris filters, 73

Detoxification, 148

Dicentrarchus labrax, 138

Direct cooling systems, 7-8

Discontinuous chlorination, 116-117

Dissociation $(\mathrm{HOCl}, \mathrm{HOBr}), 96$

DPD method, 100-101

Dreissena bugensis, 37

Dreissena polymorpha, 75, 101-107, 113-114, 129-131-140, 154-156, 158160

Drinking Water Directive, 175

Drinking water Guidelines (WHO), 177 178

Drum screen, 6

E Ecological Quality of Water Framework

Directive, 175-176

Electric fields, 158-159

Electrochlorination , 90

Elminius modestus, 111

Entosiphon sulcatum, 119

European Legislation, 169-176

Extractible Organohalogens (EOX), 92, 97, 122

F Fatty Amines, 145-151

Ficopotamus enigmaticus, 34

Filtration of water (as anti-fouling method), 4-6, 12-13, 72-74

Fouling (survey in European countries), 11-13

Fredericella sultana, 52

Freshwater Fisheries Directive, 37

Freshwater fouling, 37

Fucus serratus, 137

Fucus vesiculosus, 137

G Gammarus pulex, 119

Gloeothece, 56

Green algae, 57-58

H Haloacetic acids (HAA), 95, 99, 120

Haloacetonitriles (HAN), 95, 99

Heat treatment, 79-83, 205-206
Hydrogen Peroxide, 144

Hydroides elegans, 133

Hydroides norvegicus, 32

I Intermittent chlorination, 110-111

IPPC Directive, 175

Isothiazolones, 146-149

L Laomedea flexuosa, 132

Legionella pneumophila, 59

Lepomis macrochirus, 118

Leuciscus cephalus, 122, 143

Lophopodella carteri, 160

Lymnaea, 54-55

Lyngbia (Phormidium), 56

M Macrofouling, 18-19

Magnetic fields, 159

Mercierella enigmatica, 34

Microcysitis aeruginosa

Microfouling, 17-18, 36-37, 72, 163

Micropterus salmoides, 118

Modiolus barbartus, 21

Modiolus modiolus, 21

Molluscicides, 145

Monochloracetic acid, 120

Mosselmonitor, 111, 162-163

Mussels (marine), 20-28, 115

Mytilopsis leucophaeta, 18, 32, 35, $105,107,163$

Mytilus edulis, 18, 20-22, 25-26, 161 , 163

Mytilus galloprovincialis, 21-22, 132

Mytilus trossulus, 21-22

N Naegleria fowleri, 59

Nostoc, 56

O Oslo and Paris Convention, 177

Ostrea edulis, 30

Oxidizing compounds, 144

Oxygen deprivation efficacy on biofouling, 154-155

Oysters, 30

Ozone efficacy on biofouling, 139-141

Ozone at industrial sites, 141-142

Ozone Environmental Assessment, 142-143

Ozone production. chemistry, 138

Ozone safety of workers, 143

P Paints (anti-fouling), 83-86, 181 
Palucidella sp., 52

Pathogens, 59-60, 120-121

Pediveligers, 24, 42

Peracetic Acid, 144

Physa acuta, 75, 114, 140

Pimapheles promelas, 120

Pisidium, 50

Pleurobrachia pileus, 17

Plumatella emarginata, 52-54, 76, 140-

141

Plumatella fungosa, 52-54, 76

Plumatella repens, 82,76

Pœcilia reticulata, 119

Pomatoceros triqueter, 31

Potassium toxicity to Zebra mussels, 155

Protula tubularia, 31

Pseudomonas putida, 119

Pseudomonas aeruginosa, 58, 144

Pulse chlorination, 110-111

Purgeable Organohalogens (POX), 92

Q Quality of Surface water for Abstraction

Directive, 172.173

Quaternary Amines, 145-148

R Radix ovata, 55

Rutilus rutilus, 122

S Salmacina tribranchiata, 32

Salmo trutta iridea, 119

Scale, scaling, 12-13, 20, 60-61

Scenedesmus quadricauda, 119

Scenedesmus subspicatus, 143

Scytonema multiramosum, 56

Semibalanus balanoides, 28

Semi-continuous chlorination, 114-116

Serpula vermicularis, 31

Settlement (larval), 24-26, 29-30, 3334, 39-40, 44-45, 158

Shell fisheries Directive, 173

Shock chlorination, 112-113
Silicone based coatings, $86-88$

Siltation, 19-20

Silver, 153

Slime, 58-59, 150-151

Sphaerechinus granularis, 138

Sphaerium, 50, 52

Spirorbis, 133

Spongilla, 160

Statoblasts, 141

Strategies (treatments), 69-72

T TBTO, 154, 181

Total Organohalogens (TOX), 92

Trash, 15-16

Trash racks, 17

Travelling screens, 4-6, 73

Trichlorophenol, 120

Trihalomethans (THMs), 181

TRO decay, .91, 123-124

Tubeworms, 31-32

Tubifex tubifex, 119

Tubularia, 76-77

U Unio, 50-51, 75

UV light, 155-158, 182

V Veliger larvae, 23, 39 ,

Viviparus sp., 54-55

Vorticella campanula, 119

W Water filtration (as anti-fouling method), 72-74

Water intakes, 2-4

Water Intended for Human Consumption Directive, 173

Water velocity (as anti-fouling method), 74-79

X Xanthium strumarium

Z Zebra mussels 75, 101-107, 113-114, $129-131-140,154-156,158-160$ 